\title{
MIGRAÇÃO INTERNACIONAL A TRABALHO: \\ Contribuições para a igualdade e ética nas políticas de migração a trabalho no Brasil
}

\author{
Tese - Doutorado \\ Orientador: Professor OTÁvio PINTo E SILVA
}

FACULDADE DE DIREITO DA UNIVERSIDADE DE SÃO PAULO

SÃO PAULO

2014 


\section{NADIA TERESINHA DEMOLINER LACERDA DA SILVA}

\section{MIGRAÇÃO INTERNACIONAL A TRABALHO: Contribuições para a igualdade e ética nas políticas de migração a trabalho no Brasil}

Tese desenvolvida durante o programa de pós-graduação nível Doutorado - na área de Direito do Trabalho e da Seguridade Social, sob orientação do Professor Otávio Pinto e Silva.

FACULDADE DE DIREITO DA UNIVERSIDADE DE SÃO PAULO

SÃO PAULO 
NADIA TERESINHA DEMOLINER LACERDA DA SILVA

Banca Examinadora 
Para FERNANDO $e$ JULIA, com amor. 


\section{AGRADECIMENTOS}

Agradeço ao meu orientador, Otávio Pinto e Silva. Essa é a segunda vez que me aceitou como sua orientanda e novamente sua valiosa orientação foi decisiva para o resultado desta tese.

Aos professores Antonio Galvão Peres e Ari Possidônio Beltran, meu agradecimento pelas sugestões que fizeram durante a fase da minha qualificação e que muito colaboraram para a organização das ideias que seguem apresentadas.

Agradeço o incentivo e o apoio do Mestre e amigo Cássio Mesquita Barros. 


\section{RESUMO}

A presente tese trata da lei de migração em vigor no Brasil, a qual adotou um modelo pautado na segurança, atração de migração de profissionais qualificados e praticamente nenhum critério de ingresso e integração do migrante sem qualificação.

O modelo é colocado em discussão em um momento em que há uma tendência de crescimento da mobilidade internacional, de modo que se afigura mais do que necessário e urgente abandonar critérios ultrapassados de seleção exclusivamente baseada na nacionalidade, origem e qualificação, substituindo-os por critérios inspirados nos direitos humanos. Esse novo viés à temática migratória exige consenso bilateral e multilateral entre países emissores e receptores de migrantes.

Um debate sério sobre a modernização da política migratória brasileira deve enfrentar questões como a igualdade e a ética nas políticas governamentais e maior integração entre os Estados com respeito aos direitos humanos.

A tese busca esse debate a partir da análise dos conceitos teóricos sobre cidadania, igualdade, ética e direitos humanos, na tentativa de oferecer contribuições para a definição do modelo atual de política migratória brasileira e verifica, por amostragem, como estes princípios se efetivam no âmbito da União Europeia, do Nafta e do Mercosul.

O objetivo é contribuir para a reconstrução da atual política migratória brasileira, a partir dos pilares humanísticos levantados com a construção dos direitos humanos e que resultaram nos princípios da Convenção Internacional da ONU sobre a proteção dos Direitos de todos os Trabalhadores Migrantes e os membros de suas famílias.

Palavras-chave: migração a trabalho - migrante qualificado - migrante sem qualificação - políticas migratórias - direito do trabalho - igualdade - ética - União Europeia - Nafta Mercosul - Brasil. 


\begin{abstract}
This thesis deals with the migration law in force in Brazil, which adopted a standard based on security, aiming to only attract migration of skilled professionals and has no criteria for admission and integration of unskilled migrant.

This standard is placed on discussion in a time when there is a trend of increase of international mobility, thus it seems more than necessary and urgent to abandon outdated selection criteria solely based on nationality, origin and qualification criteria, replacing such standard by the integration of human rights. This new twist to the immigration issue requires bilateral and multilateral consensus among countries known as sending as well as receivers of migrants.
\end{abstract}

A serious debate on the modernization of Brazilian immigration policy should address issues such as equality and ethics in government policies and greater integration among the states with respect to human rights.

The thesis addresses this debate from the analysis of the theoretical concepts of citizenship, equality, ethics and human rights in an attempt to provide input for the definition of the current Brazilian standard of migration policy, as well as, a brief investigation on how these principles become effective within the European Union, Nafta and Mercosur.

The objective is to contribute to the reconstruction of the current Brazilian immigration policy, from the humanistic pillars raised with the construction of human rights, which resulted in the principles of the UN International Convention on the Protection of the Rights of All Migrant Workers and Members of their families.

Keywords: labor migration - skilled and unskilled migrants - immigration policies - labor law - equality - ethics - European Union - Nafta - Mercosur - Brazil. 


\section{RÉSUMÉ}

La présente thèse traite de la loi de migration en vigueur au Brésil, qui a adopté un modèle fondé sur la sécurité, la stimulation de la migration de professionnels qualifiés et pratiquement aucun critère d'insertion et d'intégration du migrant sans qualification.

Le modèle est discuté à un moment où il y a une tendance de croissance de la mobilité internationale, de façon qu'il s'avère très nécessaire et urgent d'abandonner des critères dépassés de sélection fondés exclusivement sur la nationalité, l'origine et la qualification, les remplaçant par des critères inspirés dans les droits de l'homme. Cette nouvelle approche à la thématique migratoire exige un consensus bilatéral et multilatéral entre les pays émetteurs et récepteurs de migrants.

Un sérieux débat sur la modernisation de la politique migratoire brésilienne doit faire face à des questions comme l'égalité et l'éthique dans les politiques gouvernementales et une plus grande intégration entre les Etats en ce qui concerne les droits de l'homme.

La thèse cherche à effectuer ce débat à partir de l'analyse des concepts théoriques sur la citoyenneté, l'égalité, l'éthique et les droits de l'homme, dans le but d'offrir des contributions pour la définition du modèle actuel de politique migratoire brésilienne et vérifie, au moyen d'un sondage, comme ces principes sont mis en place dans l’Union Européenne, dans l'ALENA et le Mercosur.

Le but est de contribuer pour la reconstruction de la politique migratoire brésilienne actuelle, à partir des piliers humanistes érigés avec la construction des droits de l'homme et qui ont abouti aux principes de la Convention Internationale de l'ONU sur la protection des Droits de tous les travailleurs migrants et les membres de leurs familles.

Mots-clés : migration pour le travail - migrant qualifié - migrant sans qualification politiques migratoires - droit du travail - égalité - éthique - Union Européenne - ALENA - Mercosur - Brésil. 


\section{SUMÁRIO}

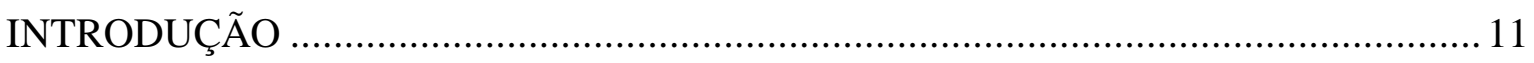

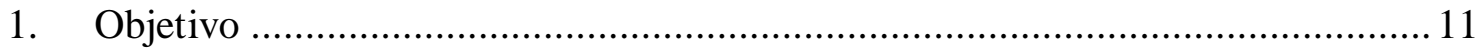

2. Caminhos para a investigação ........................................................................... 16

3. Observação quanto à restrição do tema ……………………………………..... 18

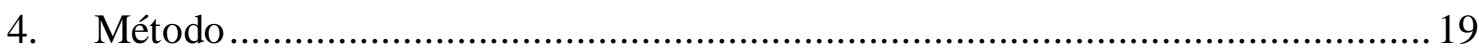

Capítulo 1. CIDADANIA VERSUS IGUALDADE E ÉTICA NA MIGRAÇÃO A

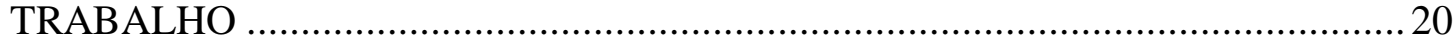

1.1 Migrante e migração a trabalho: definições, características e direitos .................. 20

1.2 Evolução do conceito de cidadania perante a construção dos direitos humanos ... 29

1.3 Igualdade e ética nas políticas migratórias...................................................... 51

Capítulo 2. A EXPERIÊNCIA ESTRANGEIRA NAS POLÍTICAS DE MIGRAÇÃO ...59

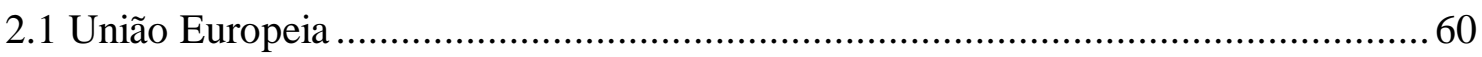

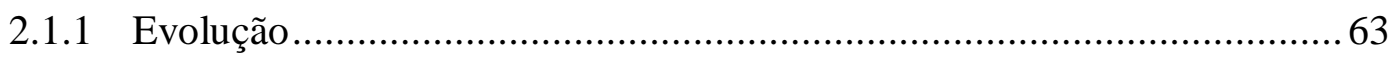

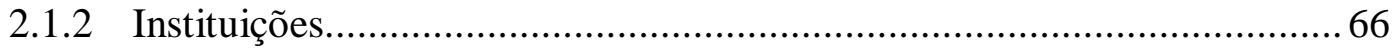

2.1.3 Regulamentos, decisões, diretivas, recomendações e pareceres ................70

2.1.4 Circulação de pessoas ............................................................................. 73

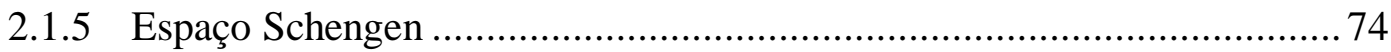

2.1.6 A cidadania europeia como fator de igualdade ....................................... 75

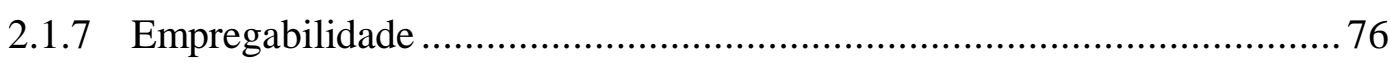

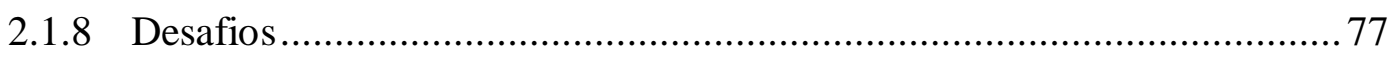

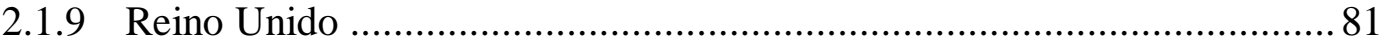

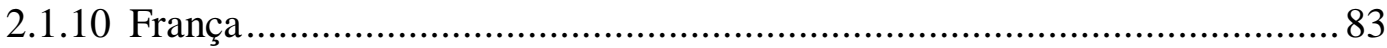

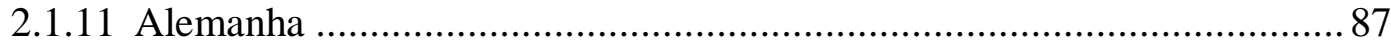

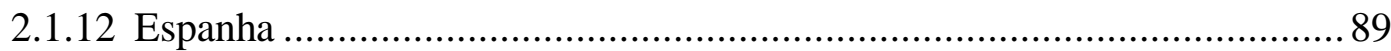

2.2 North American Free Trade Agreement (Nafta) ………………………..............91

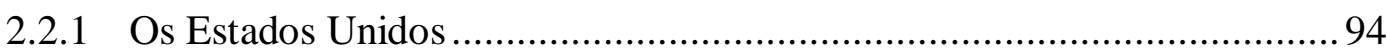

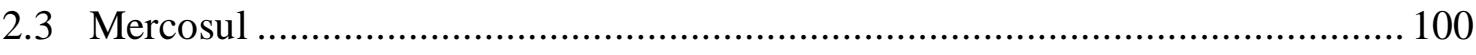

2.3.1 Incorporação e aplicação das normas do Mercosul nos ordenamentos

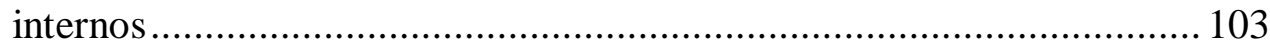

2.3.2 Circulação de pessoas no Mercosul........................................................ 104 
3.1 Breve histórico

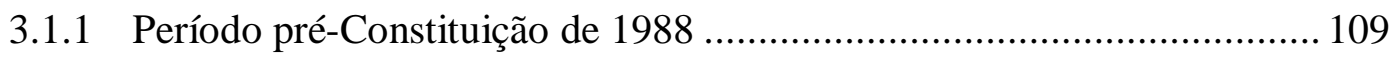

3.1.2 Período pós-Constituição de 1988 ....................................................... 110

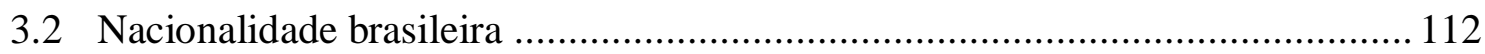

3.3 Teorias sobre os fluxos migratórios de e para o Brasil...................................... 113

3.3.1 Tipologia dos fluxos migratórios para o Brasil ................................... 113

3.3.1.1 Inserção dos imigrantes no mercado de trabalho brasileiro...... 115

3.3.1.2 Inserção dos emigrantes no mercado de trabalho estrangeiro... 118

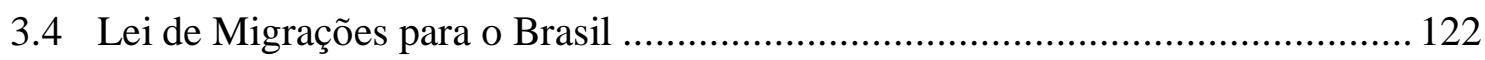

3.4.1 Lei n. 6.815/1980 - Estatuto do Estrangeiro ........................................ 122

3.4.2 Projeto de Lei n. 5.655/2009 ............................................................. 124

3.4.3 Nova proposta - Ministério da Justiça e Comissão de Especialistas....... 128

3.5 Sistema atual de gestão das políticas migratórias .......................................... 129

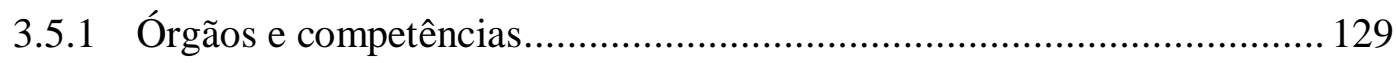

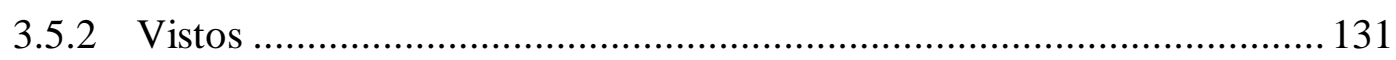

3.5.3 Conselho Nacional de Imigração e autorizações de trabalho .................. 134

3.5.3.1 Intercâmbio profissional ........................................................ 138

3.5.3.2 Eventos esportivos........................................................... 138

3.5.3.3 Assistência técnica .............................................................. 139

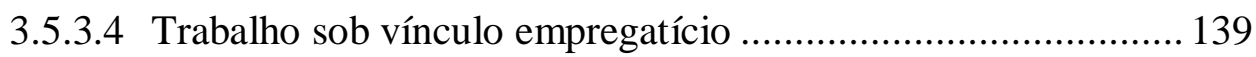

3.5.3.5 Treinamento sem vínculo empregatício................................. 140

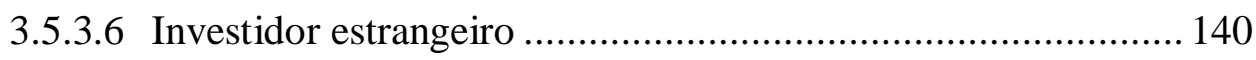

3.5.3.7 Trabalho a bordo de embarcação ou plataforma ...................... 140

3.5.3.8 Representação de instituição financeira.................................... 141

3.5.3.9 Administrador com ou sem vínculo empregatício ................... 141

3.6 Tutela jurídico-trabalhista dos migrantes no Brasil ........................................ 142

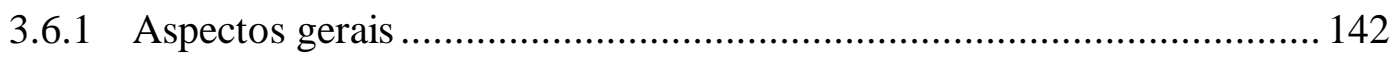

3.6.2 Restrições ao exercício de profissão liberal e revalidação de diplomas .. 145

3.6.2.1 Advocacia .................................................................... 147

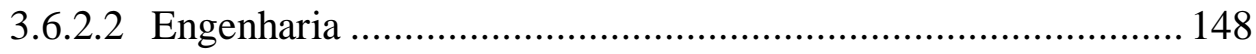

3.6.2.3 Medicina ......................................................................... 150

3.6.3 Modalidades de vínculos trabalhistas ................................................ 155

3.6.3.1 Migrantes de baixa qualificação........................................... 156 
3.6.3.2 Migrante qualificado 159

3.7 Direitos trabalhistas versus proteção ao mercado nacional 161

3.7.1 Obtenção de documentos de identificação 161

3.7.2 Proteção do mercado de trabalho nacional......................................... 162

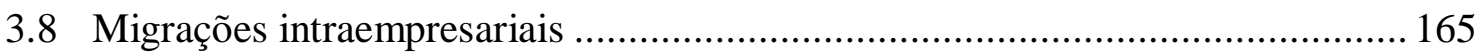

3.8.1 Lei de regência do contrato ......................................................... 167

3.8.2 Grupo econômico e unicidade contratual.......................................... 176

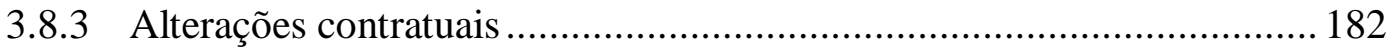

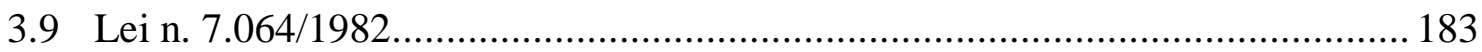

3.9.1 Disposições específicas da Lei n. 7.064/1982 ................................... 186

3.9.1.1 Trabalhadores abrangidos no Capítulo II ............................. 186

3.9.1.2 Trabalhadores abrangidos no Capítulo III .............................. 193

3.9.2 Outras questões controvertidas na Lei n. 7.064/1982 …....................... 199

3.10 Impactos das transferências no Fundo de Garantia do Tempo de Serviço

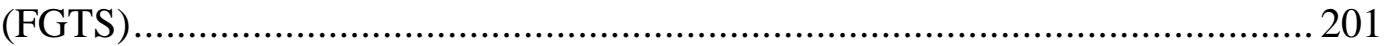

3.11 Benefícios ou ajudas de custo ajustadas contratualmente ................................206

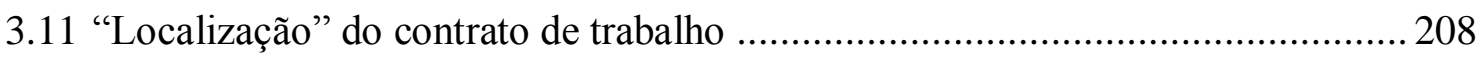

3.12 Previdência social e acordos internacionais ...................................................210

Capítulo 4. CONTRIBUIÇÕES PARA UM PROJETO HUMANÍSTICO NA

POLÍTICA DE MIGRAÇÃO A TRABALHO BRASILEIRA..............................2215

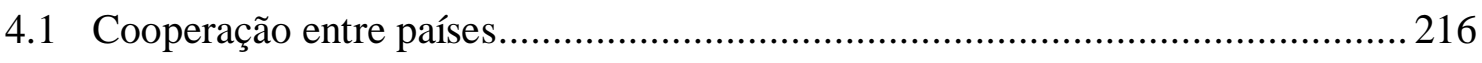

4.2 Ratificação da Convenção Internacional sobre os Direitos dos Trabalhadores Migrantes e Membros de suas Famílias ........................................................2 219

4.3 Reforma da Lei n. 6.815/1980 e integração da Lei n. 7.064/1982 ….................. 220

4.4 Acesso ao trabalho decente, com ou sem vínculo empregatício .........................224

4.5 Racionalidade e redução da burocracia e incremento de informações ................226

4.6 Participação dos corpos intermediários e da sociedade civil ............................228

4.7 Respeito aos direitos humanos mediante diálogo e consenso ..........................230

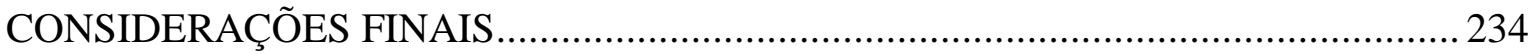

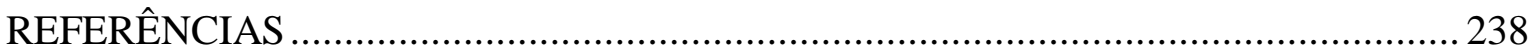




\section{INTRODUÇÃO}

\section{Objetivo}

O presente estudo empreende pesquisa doutrinária objetivando contribuir para a igualdade e a ética nas políticas de migração a trabalho no Brasil.

É orientado a partir das duas leis em vigor no Brasil sobre o tema: a) a Lei n. 6.815/1980, chamada de Estatuto do Estrangeiro, e b) a Lei n. 7.064/1982, com alteração trazida pela Lei n. 11.962/2009, que deixou de restringir os direitos aos trabalhadores contratados ou transferidos para prestar serviços no exterior, aos segmentos de engenharia, consultoria, projetos e obras, montagem etc., ampliando-os aos trabalhadores de todos os segmentos econômicos.

O momento é oportuno, pois coincide com as duas iniciativas de reforma do Estatuto em discussão no País: a) projeto de reforma do Estatuto, que tramita no Congresso Nacional desde 2009, sendo um de seus objetivos a criação de lei migratória que regula a situação e os direitos dos imigrantes e dos emigrantes; e b) os estudos em desenvolvimento pelo Ministério da Justiça a partir de 2013, por meio de comissão de especialistas nomeada especialmente para analisar e propor uma nova política migratória humanística.

O tema das migrações fomenta acirradas discussões nos meios acadêmicos, empresariais e nas entidades de proteção aos migrantes, e a principal crítica se dirige aos critérios restritivos que guiam o atual Estatuto do Estrangeiro, reconhecidamente voltados à proteção das fronteiras do País, e que se operacionalizam mediante requisitos de ingresso excludentes, que mal viabilizam o ingresso do trabalhador qualificado dado o extenso conjunto de restrições, que vão desde a vinculação obrigatória a uma empresa que deverá formular o convite, a restrição de mudar de empregador e de local de trabalho, a provisoriedade do visto, entre outras.

Nessa perspectiva, o trabalhador migrante sem qualificação técnica específica, devidamente comprovada por diploma de graduação, não encontra caminhos para se candidatar a um visto de trabalho regular de ingresso e permanência no País, uma vez que 
dificilmente conseguirá ultrapassar as barreiras que se criaram ao argumento da defesa do trabalhador nacional e dos interesses do País, preconizado no art. 2. ${ }^{\circ}$ do Estatuto. A combinação desses critérios da atual política nacional desafia o desenvolvimento econômico e humano.

A globalização tem sido a palavra-chave quando se fala em migração, tanto para ressaltar os aspectos positivos quanto negativos desse fenômeno. De fato, enquanto a globalização econômica ampliou paulatinamente o comércio internacional de bens e serviços, continua a desafiar o fluxo seguro das pessoas entre as fronteiras, fenômeno que não se verifica apenas no Brasil.

Atualmente, entende-se que a globalização repercute diretamente na produção, de forma a incrementar um processo de fragmentação que se acelera dia a dia, por conta das facilidades nas áreas de telecomunicação e informática e a melhora, ainda que tímida no Brasil, nos segmentos de logística e transporte.

Os bens industrializados de hoje podem ser projetados nos Estados Unidos, na Europa ou Japão e produzidos na China, Europa Oriental ou México. Esses novos mecanismos de produção recebem o nome de "cadeias globais de valor" e constituem um fenômeno cada vez mais presente na globalização do século XXI.

Sob o aspecto social, os arranjos na produção de bens reduziram o número de empregos diretos. Comparato chama a atenção para fábricas que podem funcionar sem nenhum empregado no local, como já observamos acontecer no segmento de energia, sendo as tarefas controladas por computadores, muitas vezes localizados em outras instalações. $^{1}$

Felizmente, outros postos de trabalho surgiram com a expansão no segmento de serviços. Como reconhece Comparato, o mercado de serviços ligados à indústria, comércio, estimulado pela urbanização da vida social, resultou na transferência de serviços, antes executados pelo poder público, para a exploração da iniciativa privada, a exemplo da educação, saúde, e aqui acrescentamos afazeres mais simples voltados a suprir

1 Fábio Konder Comparato, A civilização capitalista: para compreender o mundo em que vivemos, p. 246. 
as necessidades de uma classe média emergente no Brasil, por exemplo, os serviços de lavanderia, limpeza, jardinagem serviços de cuidadores para pessoas doentes, coleta de exames médicos nas residências.

A migração de pessoas, porém, continua sendo vista, inclusive por países desenvolvidos, como um problema, em vez de um tema que poderia perfeitamente entrar na agenda desencadeada pela globalização.

Convivemos com direitos restritos no modelo baseado no Estado, nacionalidade e cidadania e nas jurisdições territoriais. Essa realidade evoluiu de forma distinta do plano inicial e revela, por exemplo, que não se concretizou a previsão feita há dois séculos por Adam Smith, de que a interação do capital incluiria espontaneamente o livre fluxo de pessoas. ${ }^{2}$

O que se vê são nações pouco receptivas ao trabalhador estrangeiro, muito embora as nações, em geral, concordem que a migração a trabalho poderá resultar em benefício do desenvolvimento econômico, mas continuam atuando de forma a impedir o livre movimento de trabalhadores, mediante a coerção e a violência, para que as pessoas não atravessem as suas fronteiras.

Lucci e Martins apontam para uma característica comum aos países receptores em argumentar com preocupações relacionadas com a coesão social, a segurança nacional e a capacidade dos serviços públicos. ${ }^{3}$ Não encontramos, todavia, pesquisas empíricas consistentes a comprovar os impactos negativos decorrentes dos fluxos migratórios.

Aliás, um dado interessante revelado em nossa pesquisa é o paradoxo das políticas restritivas praticadas por países desenvolvidos, nos quais a população envelhece em níveis muito mais elevados do que o número de nascimentos, sendo evidente o aumento da demanda por mais pessoas em idade produtiva; todavia, esses países ainda resistem em aceitar uma política mais liberal, ética e igualitária em face dos não cidadãos.

\footnotetext{
Adam Smith, A riqueza das nações, p. 178.

3 Paula Lucci e Pedro Martins, Capítulo 1 do livro Migration and the United Nations Post-2015 Development Agenda, publicado por International Organization for Migration, ISBN 978-92-9068-681-1, 2013, p. 22.
} 
Na esteira de políticas migratórias questionáveis, até mesmo sob a ótica do que é socialmente aceitável, cerca de 3\% da população mundial vive atualmente em outro país, não onde nasceram. ${ }^{4}$ São pessoas que imigraram motivadas por razões econômicas, sociais ou políticas.

Esse percentual também inclui refugiados, pessoas em busca de asilo, trabalhadores de baixa qualificação e também altamente qualificados, empreendedores, e membros de famílias que migraram no passado.

A classe social é apontada como um fator relevante, na medida em que os países de destino competem para atrair trabalhadores altamente qualificados e o fazem a partir de regras privilegiadas para vistos de trabalho e de residência, enquanto os trabalhadores sem qualificação e os refugiados normalmente experimentam a exclusão e a discriminação. Esses fatores provocam profundas mudanças na legitimação dos Estados. ${ }^{5}$

A migração tende a crescer simultaneamente com o crescimento da globalização do mundo. Embora o fenômeno da globalização se apresenta antigo, pois perpassa a pré-história em que nômades eram impulsionados por questões físicas a buscar novos horizontes, é certo que os séculos XX e XXI trazem novos conceitos para tentar construir uma complexa estrutura, que Odete Maria de Oliveira denomina de cidadania mundial. ${ }^{6}$

A interdependência do cidadão ao meio global, no pensamento da autora, resulta na dispersão do poder estatal, na sua fragmentação como Estado-Nação, que passa a ser gradualmente ocupado por corporações transnacionais, conglomerados, organizações internacionais e não governamentais e muitos outros atores que passam a redefinir relações interconectadas e interdependentes.

Disponível em: <http://esa.un.org/migration/p2k0data.asp〉. Acesso em: 29 set. 2013.

5 Miller e Castles, The Age of migration: International Population Movements in the Modern World, p. 216-220.

6 Odete Maria de Oliveira, A era da globalização e a emergente cidadania mundial, p. 485. 
Nesse contexto, surgem cada vez mais oportunidades à migração a trabalho. Pritchett destaca pelo menos quatro forças que impulsionam a imigração a trabalho nos séculos XX e XXI. ${ }^{7}$

A primeira consiste nas diferenças salariais. Em comparação com o século XIX, o trabalhador poderá obter rendimentos muito maiores em outro país do que as diferenças salariais que impulsionavam a imigração em massa naquela época.

A segunda consiste no aumento das opções de países receptores, um fator que incentiva a imigração de jovens trabalhadores.

A terceira é identificada como o resultado da globalização de praticamente tudo em termos de produtos, com redução de custos, inclusive de passagens aéreas, de modo que a imigração tornou-se mais acessível, sobretudo à população de baixa renda.

Nesse aspecto em particular, é interessante observar a força das redes sociais na disseminação de informações sobre processos migratórios. Matéria jornalística publicada em outubro de 2013 noticiava o aumento do pedido de asilos formulado por migrantes ilegais, motivados pela alegação de "medo justificado" de perseguições em seus respectivos países de origem.

A pesquisa desenvolvida pelo jornalista Joe Millman divulga que, embora muitos desses migrantes realmente são originários de países reconhecidamente instáveis politicamente, a exemplo do Egito, Irã, Somália, representando cerca de $80 \%$ dos pedidos, houve um grande aumento de pedidos de asilo com base em "medo justificado" por razões relacionadas a conflitos particulares, sem conexão com o momento político dos países de origem.

Em 2013, o número alcançou 27.546 pedidos, contra 10.730 no ano fiscal de 2012. Um dos entrevistados por Millman, Francisco Antúnez Gutiérrez, migrante ilegal vindo de Honduras, revelou que, quando foi abordado pelos policiais da Patrulha de Fronteira, nos Estados Unidos, imediatamente pediu asilo alegando que tinha visto um

7 Lant Pritcheet, Let their people come: breaking the gridlock on international labor mobility, p. 42. 
grupo de homens atirar e matar dois traficantes e que os pistoleiros the disseram que ele seria o próximo. ${ }^{8}$

Sob essa motivação, Antúnez recusou-se a assinar o documento de regresso voluntário. Posteriormente, teria confessado ao jornalista que aprendeu a fazer isso no "Facebook". Antes de deixar a cidade natal, diz o migrante que teria se comunicado com outras pessoas na rede social, em que outros hondurenhos que requerem asilo nos Estados Unidos oferecem conselhos. Também consultou o site de migração do governo americano. A alegação de medo justificado legitima o agendamento de audiência de asilo perante um juiz de imigração que, entretanto, demora alguns meses, durante os quais o requerente é posto em liberdade condicional sem fiança para morar com parentes nas proximidades. Muitos desses migrantes jamais comparecem às audiências e, aproveitando-se da lentidão do processo, desaparecem na economia subterrânea dos Estados Unidos.

A última força motivadora decorre da contínua expansão de empregos para os quais se exige baixa qualificação, sobretudo nos países ricos, e que não são preenchidos facilmente com a força de trabalho local.

\section{Caminhos para a investigação}

Nosso estudo leva em conta a tensão que se cria entre as forças que impulsionam a migração e as barreiras impostas por políticas centradas exclusivamente nos interesses do Estado e objetiva contribuir com um referencial teórico sobre a igualdade e a ética na migração a trabalho, identificando as condições e as estruturas legais que afetam os migrantes em países receptores de significativos fluxos de migrantes a trabalhos.

A constatação de que a migração a trabalho não foi contemplada na Declaração do Milênio das Nações Unidas, adotada em 2000, ${ }^{9}$ torna ainda mais intrigante a

Matéria publicada em Wall Street Journal Americas em 17 out. 2013. Disponível em: <http://stream.wsj.comlstoryllatest-headlines\SS-2-63399\2-357147>. Acesso em: 23 out. 2013.

9 Há referências, na declaração, sobre a necessidade de combater o tráfico humano e proteção aos direitos dos migrantes, mas nenhuma a objetivos específicos voltados à proteção do trabalhador migrante. Conteúdo disponível em: <http://unic.orgไhtmellportugueseluninfolDecdoMil.pdf>. Acesso em: 14 set. 2013. 
investigação sobre a percepção das instituições acerca da relevância desse tema nas políticas nacionais, o que fazemos no intuito de responder às seguintes questões:

I. A definição dos direitos dos migrantes internacionais a trabalho sofre influências decorrentes do conceito contemporâneo de cidadania?

II. O status do migrante (sem qualificação ou qualificado) influencia de alguma maneira a formulação das atuais políticas públicas migratórias? Experiências internacionais nesse tema podem inspirar a nova política migratória brasileira, à vista da igualdade e da ética?

Para apresentarmos nossos argumentos, dividimos o estudo em quatro capítulos.

Após um breve levantamento histórico empreendido no início Capítulo 1, no intuito de demonstrar a evolução simultânea de conceitos de cidadania e dos direitos humanos, apresentamos o conceito da migração a trabalho e do migrante e, em seguida, o conjunto de direitos aplicáveis a essa tipologia de migração. Os elementos do título de nosso estudo, igualdade e ética, foram igualmente conceituados e contextualizados à luz do tema, com intuito de dar suporte ao levantamento empírico conduzido no próximo capítulo.

Escolhidos os fios condutores de nossa pesquisa, seguimos apresentando as experiências internacionais no mundo contemporâneo, as quais foram escrutinadas no Capítulo 2, no qual procuramos extrair não só os princípios norteadores das políticas migratórias nos principais blocos econômicos, incluindo a União Europeia, Nafta, Mercosul, mas também demonstrar por meio da identificação de pontos positivos e negativos os elementos que embasaram nosso estudo sobre a realidade brasileira.

Assim, a tipologia da migração a trabalho essencialmente brasileira segue apresentada no Capítulo 3, por meio da contextualização das dinâmicas da mobilidade contemporânea. Identificamos a tipologia da migração brasileira e tratamos do panorama da legislação de ingresso, permanência, enfrentando as relações jurídicas multifacetadas que envolvem o trabalhador migrante no Brasil. 
Delineamos, nesse capítulo, o mapa das instituições governamentais envolvidas com o tema, e nos aprofundamentos em questionamentos sobre conflitos de normas do direito do trabalho e da legislação de Previdência Social imbricadas nas mais diversas relações jurídicas nas quais o migrante se encontra inserido sob o ordenamento jurídico brasileiro.

Por fim, apresentamos contribuições para inovações em políticas públicas voltadas à migração a trabalho, no intuito de prover contribuições para alcançarmos efetividade na gestão humanística da migração a trabalho no Brasil.

\section{Observação quanto à restrição do tema}

O tema do presente estudo é essencialmente a migração a trabalho. Portanto, não faz parte de nosso estudo a investigação do eixo temático que trata do asilo, refúgio, deslocados por desastres naturais, tráfico de pessoas e a migração ilegal em geral, embora esses fenômenos sejam atuais e dramáticos, sob os quais pessoas são expostas a situações condenáveis sob a ótica de direitos humanos. ${ }^{10-11-12-13}$

A opção pela análise da migração que se processa pelos canais legais nos permitirá investigar normas e regras estabelecidas nesse contexto jurídico e social. Incidentalmente, a questão da migração ilegal será abordada, uma vez que a ausência de uma política migratória humanística é um fator determinante para a migração ilegal e abusos de toda espécie.

10 Para os interessados nos temas de asilo e refúgio recomendamos a leitura da obra 60 anos de ACNUR: Perspectivas de futuro, André de Carvalho Ramos, Gilberto Rodrigues e Guilherme Assis de Almeida. Disponível em: <http://www.acnur.org/t3/fileadmin/Documentos/portugues/Publicacoes/2011/60_anos_ ACNUR_Perspectivas_de_futuro_pdf?view=1>. Acesso em: 2 out. 2013.

11 Para os interessados no tema tráfico de pessoas, recomendamos a leitura da obra Tráfico de pessoas para exploração do trabalho, de Denise Pasello Valente.

12 Recomendamos a leitura da obra Tráfico de pessoas e direitos humanos, de Antonio Rodrigues Freitas Jr., Eduardo Pannunzio e Gustavo Ungaro.

13 Sugerimos a leitura das recentes RN do CNIg sobre Deslocados da Síria - RN 17, de 20 de setembro de 2013. Deslocados do Haiti - RN 97, de 12 de janeiro de 2012, Vítimas de tráfico de pessoas: RN 93, de 21 de dezembro de 2010. 
Como atesta a literatura recente sobre o tema das migrações, devemos muito às campanhas promovidas por grupos de apoio aos migrantes ilegais, que há pelo menos vinte anos vêm defendendo um tratamento mais digno e humano aos migrantes, lançando luzes sobre os problemas que afetam as políticas migratórias, a exemplo da discriminação por raça, condição social, nacionalidade, entre outros. ${ }^{14}$

Esse corte temático, centrado na migração a trabalho, nos permitirá concentrar a análise nas políticas de autorização de ingresso dos migrantes no território do país em que buscam trabalho e novas perspectivas de vida, os critérios que definem a quem será dado o visto de trabalho, como essas políticas atuam para regular o número de indivíduos a quem se permitirá trabalhar no país receptor, as competências profissionais exigidas, o tempo máximo de permanência permitido e, finalmente, quais os direitos assegurados a esses indivíduos.

\section{Método}

Para a abordagem dos temas estudados optamos pelo método dialético, mais comumente utilizado na área jurídica do que o método indutivo ou dedutivo.

A leitura inicial do vasto material já escrito sobre o tema da migração internacional revelou que o método de abordagem dialético serve muito bem aos propósitos de nosso estudo, pois é pautado no levantamento dos mais diversos posicionamentos sobre a migração internacional a trabalho, perante a igualdade e a ética, o que nos levará a uma conclusão possível sob o ordenamento jurídico brasileiro.

O método de procedimento será em grande parte histórico, largamente utilizado para a investigação dos acontecimentos e instituições do passado, a fim de que se tenha uma base sólida para a nossa análise do fenômeno da migração internacional sob o princípio da igualdade e da ética.

14 Rossana Roha Reis, A política do Brasil para as migrações internacionais. Disponível em: <http://dx.doi.org;10.1590\SO102-85292011000100003\&Ing=en\&nrm=iso>. Acesso em: 5 out. 2013. 


\section{Capítulo 1 \\ CIDADANIA VERSUS IGUALDADE E ÉTICA NA MIGRAÇÃO A TRABALHO}

\subsection{Migrante e migração a trabalho: definições, características e direitos}

Em nossos dicionários a palavra migrante exprime aquele que mudou de país, que passou de um lugar para outro. ${ }^{15}$ A ONU define migrante como o indivíduo que reside em território de outro país por período superior a um ano, independentemente das causas que o impeliram a migrar. ${ }^{16}$

O migrante é, como define Canotilho, um sujeito exposto a muitas “máscaras jurídicas", tanto pode ser encarado como o trabalhador quanto o sujeito inserido em grupos de risco que justificam a prevenção e reação penal ou, ainda, um desenraizado cultural ou membro de minoria étnica, de toda forma, vítima ou agente à procura de um estatuto de cidadania entremeado por normas constitucionais, comunitárias, cíveis, laborais, educativas e penais. $^{17}$

Para Sayad, o trabalhador migrante é uma força de trabalho em caráter provisório, temporário, em trânsito. Em virtude desse princípio, ressalta o autor que a provisoriedade acompanha o migrante durante toda a sua vida no país de destino, ou seja, mesmo quando pretende se estabelecer de forma permanente no país de destino, continuará sendo tratado como um indivíduo de passagem, sujeitando-se à revogação de direitos a qualquer momento. ${ }^{18}$

A imigração a trabalho, na definição da Organização Internacional para a Migração (OIM), envolve o movimento de entrada ou de saída de indivíduos em países diferentes, sob um visto de trabalho, e esse é o tema principal do nosso estudo, porém é

15 Antônio Houaiss e Mauro Salles Villar, Dicionário Houaiss da língua portuguesa, p. 1920.

16 Informação disponível no sítio da Organização Internacional para Imigração: <http://www.oim.int/cms/ en/sites/iom/home/about-migration/key-migration-terms>. Acesso em: 29 set. 2012.

17 J.J. Gomes Canotilho, Enquadramento jurídico da imigração, p. 153. Disponível em: <http://www.museu-emigrantes.org/docs/conhecimento/actas_Icongresso\%20em\%portugal.pdf >. Acesso em: 28 set. 2013.

18 Abdelmaleck Sayad, A imigração: ou os paradoxos da alteridade, p. 290. 
nesse momento que se coloca o problema de justificar a escolha dessa tipologia de migração dentre tantas outras existentes.

Todo migrante é um emigrante e vice-versa. A imigração se refere ao movimento de ingresso do indivíduo no país, mas também na saída de seu país, com efeitos associados, o que se coloca sob um tema extremamente complexo.

Para se ter uma ideia, em 2013, aproximadamente 215 milhões de pessoas foram consideradas migrantes, a partir da definição das Nações Unidas, que leva em conta todas as pessoas que vivem em outro país, diferente daquele em que nasceu, por um período superior a um ano. Cerca de metade desse contingente é tida como migrantes a trabalho. ${ }^{19}$

O migrante a trabalho recebe ainda a classificação de: migrante documentado, como um sinônimo para definir o indivíduo que ingressa sob o visto apropriado e permanece no país sob os direitos assegurados conforme os critérios definidos pelo país de destino, de acordo com a modalidade de visto concedido.

Em contraposição ao migrante documentado, cunhou-se há cerca de quinze anos o termo indocumentado, clandestino ou trabalhador não documentado.

Conforme nossa observação anterior, essa categoria de migrante não será objeto de nosso estudo em virtude da opção de concentrarmos o estudo nas normas e regras estabelecidas nesse contexto jurídico e social que analisaremos, na busca de identificar os problemas que afetam e impedem o pleno exercício de direitos por essa categoria de migrantes. $^{20}$

Logo, propomos uma classificação mais simples, de forma a facilitar a investigação das políticas migratórias, que é conduzida no Capítulo 2. Optamos por

19 Disponível em: <http://www.un.org/esa/population/publications/migration/WorldMigratonReport2013. pdf>. Acesso em: 31 ago. 2012. ILO. International Labor Migration: A rights-based approach. Geneva: ILO, International steering Committee for Campaign for ratification of the migrants rights convention on the protection of the rights of all migrants and members of their families. Geneva, 2010. Acesso em: 31 ago. 2013.

20 Martin Ruhs, The price of rights: regulating international labor migration, p. 12. 
classificá-los apenas em dois tipos: a) migrante qualificado e b) migrantes sem qualificação.

Na perspectiva do migrante sem qualificação, adotamos o conceito de Accioly, que classifica nessa categoria o grupo de trabalhadores sem qualificação, ou seja, de baixo nível educacional. Acrescentamos a essa categoria os trabalhadores sem experiência profissional relevante que os qualifique para assumir posições de trabalho mais bem remuneradas, quando comparadas aos migrantes com formação profissional. ${ }^{21}$

A mobilidade dessa categoria de migrantes está normalmente relacionada à necessidade por melhores condições de vida, sobrevivência e refúgio. Rezera destaca que os locais de origem se constituem em cidades incapazes de suprir necessidades básicas da população, em áreas como subsistência, moradia, saúde, educação, geração de emprego e de mecanismos que garantam minimamente a permanência digna dessas pessoas em seus locais de origem. ${ }^{22}$

O perfil de ocupações disponíveis para essa categoria de migrantes passou por alterações significativas nos últimos trinta anos. Jannuzzi, em estudo sobre as ocupações urbanas disponíveis na cidade de São Paulo para os migrantes de baixa qualificação, revela que na década de 1980 se destacavam as vagas de emprego na indústria, que reunia a maior parte dos migrantes então ocupados na região da cidade de São Paulo. ${ }^{23}$

Em seguida, paralelamente às atividades de agropecuária no interior do Estado de São Paulo, vinham as ocupações urbanas desenvolvidas no comércio, serviços auxiliares, prestação de serviços sociais e, por fim, a construção civil e os serviços domésticos.

21 Tatiana de Almeida Accioly, mestre em geografia, no artigo intitulado Mobilidade da mão de obra qualificada no mundo atual: discutindo os conceitos de brain drain, brain gain, brain waste e skill exchange. VI Encontro Anual de migrações - ABEP. Disponível em: <http://www.abep.nepo. unicamp.brldocslanaisloutrosl6EncNacSobreMigrações|ST3\Tatiana AlmeidaAccioly.pdf>. Acesso em: 8 out. 2013.

22 Danielle do Nascimento Rezera, Gênero e trabalho: mulheres bolivianas na cidade de São Paulo 1980 a 2010, p. 13.

23 Paulo de Martino Jannuzzi, Migração e mobilidade no mercado de trabalho, p. 108-116. 
A década de 1980 é também marcada pelo ingresso de bolivianos, que começam a chegar clandestinamente em São Paulo, para substituir o trabalho de coreanos nas indústrias de confecção. ${ }^{24}$

Os empregados com “carteira assinada” representavam, na década de 1980, mais da metade do contingente de migrantes ocupados. Esse perfil na década de 1990 foi cedendo gradual espaço para a expansão de migrantes autônomos, tornando-se empregadores em pequenos negócios, mostrando uma tendência previsível à luz das transformações nos processos produtivos que mencionamos na introdução de nosso estudo.

Cacciamali observa que houve uma deterioração da proteção social dos migrantes de baixa qualificação, pois os mecanismos de trabalho foram transferidos da esfera dos empregados por tempo indeterminado para o âmbito dos assalariados de curta duração (temporários), além de trabalhos irregulares, em pequenos estabelecimentos, por conta própria e os trabalhos em domicílio. ${ }^{25}$

Em relação ao migrante qualificado, Martin propõe duas abordagens para a análise das políticas migratórias: a primeira leva em consideração a demanda das empresas por profissionais especializados e a segunda, analisa o fenômeno sob a ótica da oferta desses profissionais em âmbito global. ${ }^{26}$

Quanto à demanda das empresas, as políticas que se verificam centradas nessa ótica, a exemplo dos Estados Unidos, funcionam mediante a iniciativa das empresas, que solicitam aos órgãos competentes a contratação do migrante qualificado, devendo, para tanto, comprovar, junto às agências especializadas, a inexistência de nacionais com qualificação similar ao do migrante.

Em relação aos sistemas baseados na oferta de migrantes qualificados, trata-se das políticas que atuam por sistemas de pontos, a exemplo da Austrália e do Canadá, em

24 Danielle do Nascimento Rezera, Gênero e trabalho: mulheres bolivianas na cidade de São Paulo 1980 a 2010, p. 27-30.

25 Maria Cristina Cacciamali, As políticas ativas de mercado de trabalho no Mercosul. Disponível em: <http://dx.doi.org/10.1590/SO103-4014200500030007>. Acesso em: 5 jul. 2013.

26 Susan Martin, US Employment-based admissions: Permanent and temporary, Migration Policy: admission of high skilled workers, p. 619-636. 
que é considerada a disponibilidade de profissionais nacionais qualificados. Quanto menos profissionais com determinada especialização, maior a pontuação atribuída a um migrante interessado em ingressar no país com base em suas qualificações técnicas e educacionais.

A migração do trabalhador qualificado acarreta um debate sobre as consequências que produzem nas economias dos respectivos países de origem e de destino. Nesse aspecto, Coentro apresenta duas correntes de pensamento: a baseada no capital humano (restrita a uma perspectiva econômica) e a baseada no capital social (que avalia os conhecimentos e as habilidades do indivíduo como um fator de produção, com influência sobre investimentos que o país receptor deverá realizar em educação).

A perspectiva humana, segundo Coentro, propicia maior retorno ao detentor desse capital, no caso o próprio migrante, que alcançará maior renda individual em contrapartida à realização de trabalho de maior qualificação.

A análise dessas perspectivas nos conduz à outra terminologia usualmente empregada por estudiosos dos fluxos migratórios de trabalhadores qualificados: brain drain, brain gain e o brain waste. ${ }^{27}$

Brain drain (drenagem de cérebros) é definida por Coentro como a migração e profissional altamente qualificado do país que proveu essa qualificação. A ocorrência desse fenômeno é relacionada a consequências negativas para o país de origem do migrante, sobretudo no caso de países em desenvolvimento, uma vez que repercute em perda de capacidade de produção, inovação e retrocesso na área científica.

O fenômeno do Brain gain (ganho de cérebros) refere-se ao efeito positivo da migração do profissional altamente qualificado para ambos os países. O país de destino receberá o talento e habilidades, incorporando ao mercado de trabalho nacional, enquanto o país de origem se beneficiará das remessas de capitais e, em muitos casos, nota-se que há um retorno ao país de origem após determinado período de expatriação, proporcionando a transferência de conhecimento adquirido ao mercado nacional do país de origem.

27 As definições foram resumidas do conteúdo das obras de Tatiana de Almeida Accioly, A circulação internacional de mão de obra qualificada na atualidade: políticas imigratórias dos Estados Unidos e Canadá e o escritório de imigração do Quebec em São Paulo; e Luciana Unis Coentro, Políticas públicas e gestão das migrações internacionais do Brasil: uma reflexão sobre os migrantes qualificados, p. 20-22. 
Por sua vez, o conceito de brain waste (desperdício de cérebros) é a consequência das políticas migratórias que nem beneficiam os países de origem nem os países de destino, em razão do subaproveitamento da capacidade e da potencialidade do migrante, ocasionado, por exemplo, pela restrição do exercício da profissão no país de destino. Vale aqui acrescentarmos nossa percepção de que esse fenômeno se comprova na grande quantidade de engenheiros e médicos em ocupações como motorista de táxi que encontramos em vários países desenvolvidos, como os Estados Unidos, o Canadá, a França, Londres, entre outros.

Embora esse tenha sido o recorte escolhido, é igualmente necessário estabelecer quais os direitos dos trabalhadores migrantes, como se estabelecem as relações jurídicas em concreto e como tais relações se subordinam às normas de direito nacional e internacional, que seguem abordados no item seguinte.

Uma vez definido o trabalhador migrante, como o titular dos direitos que nos propomos a estudar, é necessário identificar quais esses direitos.

$\mathrm{O}$ argumento comumente difundido na doutrina caminha no sentido de que os direitos dos migrantes equivalem aos direitos humanos, o que é absolutamente verdadeiro. Assim, a definição concreta desses direitos só pode ser feita por meio do estudo da evolução de seu reconhecimento.

Nadia Araujo ${ }^{28}$ destaca como marco essencial no reconhecimento dos direitos dos estrangeiros as declarações inseridas em textos constitucionais a partir do século XVIII, defendendo que esses instrumentos contemplaram os direitos humanos com uma dimensão permanente e segura. A Revolução Francesa afirmou a igualdade entre todos os homens e acarretou o rompimento com o direito obtido pelo nascimento, dando lugar à criação do estado de direito democrático com base na igualdade, fraternidade e liberdade.

Para Celso Lafer, os direitos humanos não seguem uma trajetória linear, mas uma história de combate. ${ }^{29}$ Hannah Arendt complementa ressaltando a história de

28 Nadia de Araujo, Direito internacional privado: teoria e prática, p. 25.

29 Celso Lafer, Prefácio ao livro Direitos humanos e justiça internacional, de Flávia Piovesan, p. XXII. 
construção e contínua reconstrução dos direitos humanos. ${ }^{30}$ Trata-se de um direito de proteção que Cançado Trindade destaca ser voltado à salvaguarda dos direitos dos seres humanos, e não dos Estados. ${ }^{31}$

Norberto Bobbio atribui a essa concepção individualista dos direitos humanos o significado de que são direcionados ao indivíduo, pela simples razão de que o Estado é feito pelo indivíduo, e não o indivíduo pelo Estado. ${ }^{32}$

Daí o nosso sentir de que o tema da imigração internacional, pela sua complexidade, desafia a efetivação de um conjunto amplo de direitos reconhecidos internacionalmente aos migrantes.

Desde 1948, quando foi proclamada a Declaração Universal dos Direitos Humanos, cujo art. 13 assegura a todos o direito à liberdade de locomoção, perde-se gradualmente o sentido de perquirir sobre as causas que levam o ser humano a imigrar, enquanto ganha espaço a reflexão em torno da garantia de direitos ao indivíduo durante o período que não está sob a proteção de seu Estado de origem. ${ }^{33}$

Os direitos humanos ligados às garantias individuais do ser humano, como o direito à vida, à liberdade, à igualdade, à segurança, como lembra Wagner Menezes, compõem uma esfera de direitos subjetivos do indivíduo conhecida como "liberdades públicas" garantidas desde a Declaração Francesa dos Direitos do Homem e do Cidadão, de 1789, e confirmados nos arts. 1. ${ }^{\circ}$ e 21 da Declaração dos Direitos do Homem e do Cidadão, de $1948 .^{34}$

Os direitos econômicos e sociais dos migrantes, exercidos no seu trabalho, no seu lazer, abrangem o direito à saúde, educação, cultura, e foram consagrados nos arts. 22 a 27 da Declaração Universal dos Direitos do Homem e do Cidadão.

\footnotetext{
30 Hannah Arendt, As origens do totalitarismo, p. 90.

31 Augusto Antonio Cançado Trindade, Tratado de direito internacional dos direitos humanos, p. 20.

32 Norberto Bobbio, Teoria geral da política: a filosofia e as lições dos clássicos, p. 480.

33 Disponível em: <www.dhnet.org.br/direito/deconu/textos/integra>. Acesso em: 3 set. 2013.

34 Wagner Menezes, Ordem global e transnormatividade, p. 62.
} 
Ingo Wolfgang Sarlet cita ainda os direitos ao meio ambiente e qualidade de vida, direitos esses que a doutrina reconhece de difícil reivindicação, uma vez que se encontram ainda em fase de inserção no âmbito do Direito Internacional. ${ }^{35}$

Os demais direitos foram incorporados à medida que evoluíram as instituições e os tratados internacionais sobre direitos humanos. Sem dúvida, o primeiro e mais importante direito dos trabalhadores migrantes, além do direito à vida, é a liberdade de ir e vir, de deixar e de regressar ao país de origem.

A Convenção Internacional sobre os Direitos de todos os Trabalhadores Migrantes e os Membros de suas famílias, adotada em 1990 pela Assembleia-Geral das Nações Unidas, garante um compreensível conjunto de direitos civis, políticos, econômicos e sociais para os trabalhadores migrantes, inclusive para aqueles que vivem ilegalmente fora de seus países de origem, constituindo-se no mais abrangente tratado internacional voltado à proteção dessa categoria de migrantes. Essa Convenção será analisada no item subsequente. ${ }^{36}$

Ao concluirmos que os direitos dos migrantes englobam os direitos humanos, é necessário perquirir sobre os entraves à sua plena eficácia.

A evolução da condição jurídica do estrangeiro em relação ao país receptor é permeada da ideia de exclusão. Quando o indivíduo migra, não mais circunscreve as suas relações apenas às fronteiras do Estado de origem. Na grande maioria dos casos, o indivíduo mantém a sua cidadania originária, mas estabelece relações relevantes, temporárias ou permanentes com outros Estados. Muitas vezes, sem se dar conta, o indivíduo se vê envolvido em situações jurídicas transnacionais, sobretudo quando a contratação de seus serviços se dá no país de origem e se desenvolve ao longo do tempo em outras jurisdições.

A relação de cidadania de um indivíduo no tocante a determinado Estado constitui, na visão de Tito Ballarino, um triplo valor: primeiro, assegura ao indivíduo um

\footnotetext{
35 Ingo Wolfgang Sarlet, A eficácia dos direitos fundamentais, p. 63.

36 Disponível em: <http://www.un.org\News\Press\docs\2003\sgsm9081.doc.htm>. Acesso em: 3 mar. 2012.
} 
vínculo de pertinência ao Estado, o qual é relevante para o direito internacional público. Segundo, serve como um mecanismo a regular os direitos pessoais do indivíduo e dar-lhe garantias nas relações que envolvem o direito privado, aí incluídas as que decorrem das relações familiares e sucessórias. Terceiro, e, a nosso ver, o que mais o diferencia do indivíduo estrangeiro, confere-lhe os direitos políticos e de acesso aos cargos públicos e as profissões regulamentadas por lei. ${ }^{37}$

A diferença de tratamento entre nacionais e estrangeiros (ou a ausência de igualdade) permaneceu por longo tempo escondida sob o argumento da necessidade de defesa do lugar conquistado, um pedaço do mundo dividido pela diferença de fronteira geográfica.

Trata-se da história da cidadania, que Canotilho coloca como um código explicitamente binário de inclusão/exclusão. ${ }^{38}$ Se de um lado oferece aos cidadãos que se transferiram ao exterior, bem como aos seus descendentes, uma identidade que os liga ao país de origem, por outro lado, pela aplicação desse mesmo conceito de pertinência, os coloca perante um conjunto de direitos fragmentados, pelo fato de não pertencerem ao local de destino.

A origem desse conceito de espaço local, de povo e de cidadania como um divisor de direitos e de diferentes obrigações atribuídas a um indivíduo nacional em comparação com um estrangeiro é identificada a partir dos povos romanos. Naiara Posemato destaca a experiência romana da civitas que caracterizou a cidadania exclusivamente entre o indivíduo e a autoridade e praticamente esvaziou o não cidadão de direitos, inclusive na esfera privada. ${ }^{39}$

De maneira geral, a ideia de direitos atrelados à cidadania é tão arraigada ao longo de nossa cultura que é necessário indagar sobre o que aconteceu antes de nosso

37 Tito Ballarino é livre-docente e professor de Direito Internacional na Università delgi Studei di Padvoa. Docente de Direito das Comunidades Europeias na Università Cattolica di Milano, Itália, e suas considerações foram extraídas do livro Cidadania e nacionalidade: efeitos e perspectivas nacionais regionais - globais, p. 70-86.

38 J.J. Canotilho, Enquadramento jurídico da imigração, p. 154.

39 Naiara Posemato é mestre em Direito Internacional da Università degli Studi di Padova e pesquisadora da Fondazione Cassamarca de Treviso, Itália - no livro Cidadania e nacionalidade: efeitos e perspectivas nacionais - regionais - globais, p. 212-213. 
tempo presente, quais as origens e a evolução do conceito de cidadania que o coloca em contraposição à igualdade jurídica e impede que as importantes conquistas na esfera dos direitos humanos envolvam o indivíduo estrangeiro.

O breve histórico que apresentamos a seguir propiciará expor a dicotomia entre cidadania e direitos dos trabalhadores migrantes.

\subsection{Evolução do conceito de cidadania perante a construção dos direitos humanos}

Neste tópico propomos um rápido mergulho na história das civilizações antigas, passando pela Idade Média, Renascimento e pelos principais instrumentos internacionais que influenciaram a construção do que hoje conhecemos como os direitos humanos e que evidentemente equivalem aos direitos de todas as pessoas, cidadãos ou não do país em que vivem e assim também devem ser garantidos aos trabalhadores migrantes.

Roma foi a primeira cidade Estado a se utilizar de um elemento de ligação entre o indivíduo e a circunstância de pertencer ou não a uma determinada gens, termo que denominava os romanos de origens rurais, que conferia ao indivíduo liberdade e capacidade jurídica. $^{40}$

A característica mais marcante da cidadania, segundo o pensamento de Gaio, foi o reconhecimento da prevalência do critério de jus sanguinis nas três hipóteses para o reconhecimento da cidadania romana: filho de cidadão romano concebido de um casamento regular, independentemente da cidadania da mãe; filho nascido de casamento que não atendia às exigências do direito romano, mas de mãe cidadã romana e filho de estrangeiros (peregrinus) regularmente estabelecidos em Roma, desde que fruto de um casamento regular e após a concessão do estatuto de peregrinus ao pai. Trata-se de uma ideia primitiva de Estado, por meio da qual eram exercidos direitos e obrigações baseados na ideia patriarcal na sua forma mais extrema. ${ }^{41}$

40 Arno Dal Ri Junior, Cidadania e nacionalidade: efeito e perspectivas: nacionais - regionais - globais, $\mathrm{p}$. 32-36.

41 Gaio, Institutes of Roman Law (Fonte: Gaius, 1904, obra traduzida e comentada por Edward Poste, M.A, p. 15-16). Disponível em: 〈http://files.libertyfund.org/files/1154/Gaius_0533_EBk_v6.0.pdf〉. Acesso em: 11 maio 2013. 
Em seguida, com a expansão do império romano, veio a necessidade de assegurar certos direitos aos povos vencidos para manter a coesão e o desenvolvimento da concepção de Estado.

O direito romano passa então a atribuir alguns direitos aos estrangeiros, bem distintos e inferiores às prerrogativas conferidas aos cidadãos. Nasceu assim o jus civile, reservado aos nascidos nas cidades romanas e aos seus filhos, e o jus gentium, mediante o qual se estendiam determinados e restritos direitos aos estrangeiros.

Sob essa concepção, aos estrangeiros, desde que livres, era aplicado um direito que lhes possibilitava o reconhecimento do casamento, porém com efeitos inferiores aos conferidos a um cidadão romano. Igualmente o direito de propriedade sobre a terra era-lhes concedido de forma restrita em comparação com o direito atribuído aos romanos. ${ }^{42}$

O status de cidadão romano era de tal maneira superior que conferia ao seu possuidor prerrogativas de ampla liberdade que se colocava até mesmo como uma limitação ao poder dos magistrados.

Exemplos do uso do instituto da cidadania romana são encontrados em alguns versículos da Bíblia, a exemplo do livro Atos dos Apóstolos, em que há passagens em que São Paulo lança mão de sua condição de cidadão romano para obter o relaxamento de prisão. $^{43}$

Avançando um pouco na história da Idade Média, observamos a deterioração dos direitos assegurados pela cidadania romana, a qual Arno Dal Ri Júnior denomina de "vulgarização" da cidadania causada pela concessão da cidadania romana a todos os

42 Jean Gaudemet, Eglise et societé en occident au moyen age, p. 209.

43 “Atos dos Apóstolos, 37-40 ... Paulo, porém lhes replicou: Sem ter havido processo formal contra nós, nos açoitaram publicamente e nos recolheram ao cárcere, sendo nós cidadãos romanos; querem agora, às ocultas, lançar-nos fora? Não será assim; pelo contrário, venham eles e, pessoalmente, nos ponham em liberdade. Os oficiais de justiça comunicaram isso aos pretores; e estes ficaram possuídos de temor, quando souberam que se tratava de cidadãos romanos. Então, foram ter com eles e pediram desculpas; e, relaxando-lhes a prisão, rogaram que se retirassem da cidade” (A Bíblia Sagrada, p. 163). 
indivíduos residentes nos territórios anexados pelo Império, e que coincide com a formação de pequenos reinos, transformando os respectivos habitantes em súditos. ${ }^{44}$

Com a queda do Império Romano, em consequência da invasão dos povos bárbaros, surgem o feudalismo e a submissão dos cidadãos aos domínios do senhor feudal. Paralelamente, há a afirmação da autoridade da Igreja como representante de Deus na terra, desenhando um esquema de relações de poder que impõe normas de cunho religioso sobre os súditos.

$\mathrm{Na}$ época feudal, diante dessa centralização absolutista de poder de caráter personalista e patrimonial, a cidadania perdeu o sentido que lhe havia incutido o direito romano.

Os estrangeiros ou se submetiam aos domínios do senhor feudal ou eram considerados fora da lei. O estrangeiro, quando permitido viver sob o domínio de determinado feudo, era titular de direitos inferiores aos considerados locais; era permitido o exercício de atos de comércio e o casamento com pessoa local, mediante o pagamento de um tributo, mas não era detentor dos direitos de propriedade, e qualquer cidadão poderia se apoderar dos bens do indivíduo estrangeiro como compensação por quaisquer ofensas que tivesse sofrido no território de origem deste. ${ }^{45}$

O sentido de cidadania somente reapareceu, ainda que precariamente, em meados do século XVI, quando se desenvolve a expansão colonial europeia e tem início uma série de relações com as colônias conquistadas, envolvendo domínio dos mares, fronteiras e rios e a retomada dos ideais de participação política dos indivíduos.

Nessa época, as ideias do filósofo francês Jean Bodin sobre a unidade do poder estatal resgatam elementos do antigo conceito romano de cidadania, muito embora com o propósito de legitimar uma estrutura rígida de poder de um Estado absoluto, com poder de

44 Arno Dal Ri Junior, Cidadania e nacionalidade: efeito e perspectivas: nacionais - regionais - globais, p. 39.

45 Rui de Albuquerque e Martim de Albuquerque, História do direito português, p. 33. 
comando de um indivíduo sobre os outros, uma verdadeira relação entre soberanos e cidadãos. $^{46}$

A ideia central preconizada por Bodin era a liberdade ao cidadão e o princípio de igualdade reservado aos cidadãos perante a lei, e que evidentemente não alcançava os servos e escravos.

O cidadão possuía um status jurídico que o intitulava a um patamar de relações distintas e privilegiadas com o soberano, enquanto os servos, assim como os estrangeiros, não poderiam gozar do exercício de direitos e privilégios privativos de cidadãos.

Posteriormente, a partir do renascimento, o pensamento filosófico sobre o direito faz ressurgir ideias de igualdade e dignidade do homem. Thomas Hobbes elaborou uma releitura das ideias de Bodin, aprimorando o conceito de igualdade de todos perante a lei. Arno Dal Ri Júnior destaca que a teoria hobbesiana foi colocada em prática pelos Estados liberais do século XVII como inspiração para a ideia moderna de cidadão como titular de uma série de direitos subjetivos perante o Estado. ${ }^{47}$

Na sequência, Jean-Jacques Rosseau apresentou a evolução dessa teoria, na obra Do contrato social, na qual se observa a crítica à escravidão. "As palavras escravatura e direito são contraditórias, excluem-se mutuamente, seja de homem para homem, seja de um homem para um povo, este discurso será a concepção de sociedade, de lei natural e de vontade geral e de governo". 48

Segundo essa leitura, o contrato social é uma convenção entre associados em proveito da comunidade em seu conjunto que confere poder ao governo para a

46 Jean Bodin, Le xis livres de La République: Paris: A Lyon Libraire iure em L'uniuerfité, LXXIX. Disponível em <https://play.google.com/books/reader?id=T3VMAAAAcAAJ\&printsec=frontcover\& output=reader\&authuser=0\&hl=pt_BR>. Acesso em: 11 maio 2013.

47 Hobbes, the cive, London: R.Royston, Lane, 1651. Disponível em: <http://www.unilibrary.com/ebooks/ Hobbes,\%20Thomas\%20-\%20De\%20Cive.pdf>. Acesso em: 11 maio 2012.

48 São essas as palavras de Rosseau sobre a escravidão: "É nulo o direito de escravizar, não só pelo fato de ser ilegítimo, como também porque é absurdo e nada significa: 'faço contigo um contrato, todo em teu prejuízo e todo em meu proveito, que eu observarei enquanto me aprouver e que tu observarás enquanto me aprouver"'. Jean-Jacques Rousseau, tradução de Rolando Roque da Silva, ed. Ridendo Castigat Moraes. São Paulo, 2002. Disponível em: <http://www.dominiopublico.gov.br/download /texto/cv00014a.pdf>. Acesso em: 12 maio 2013. 
representação dos cidadãos e de seus direitos, ainda que com a intervenção de um soberano.

A base doutrinária até aqui exposta inspirou pelo menos dois marcos históricos essenciais à afirmação dos direitos humanos como universal e positiva, não mais contida aos cidadãos deste ou daquele Estado, mas a todas as pessoas, de modo a serem reconhecidos e protegidos até mesmo com medidas aplicáveis contra o próprio Estado: A Declaração de Direitos da Virgínia, de 1776, e a Declaração dos Direitos do Homem e do Cidadão, de 1789.

Ambas representaram a proteção do indivíduo contra arbitrariedades do Estado, porém não o protegeram dos efeitos perversos do sistema econômico que se seguiu com o uso da máquina a vapor nos processos produtivos, momento histórico conhecido como a Revolução Industrial, nos séculos XVIII e XIX. ${ }^{49}$

Essas primeiras declarações rompem com a ideia de direitos restritos a determinados cidadãos e se dirigem, como reconheceu Bobbio, "a um homem racional fora do espaço e do tempo", ainda que com direitos limitados quanto à sua eficácia, uma vez que o Estado os deveria reconhecer. ${ }^{50}$

A trajetória expansiva da cidadania altera também o eixo de ligação entre o indivíduo e o Estado, como aponta Gilmar Antonio Bedin, a soberania passa a ser pensada de forma integrada, coordenada por um sistema de jurisdição internacional. ${ }^{51}$

$\mathrm{Na}$ verdade, a ideia de direitos restritos ao povo local, sob o comando do Estado, somente se rompe com a Declaração Universal dos Direitos do Homem de 1948, a partir de quando os direitos restritos a um Estado se tornam os direitos de todos os homens.

Esse movimento é mundialmente conhecido como a internacionalização dos direitos humanos em detrimento da valorização excessiva do Estado, em uma época de

49 Enrique Ricardo Lewandowski, A formação da doutrina dos direitos fundamentais, p. 172-173. O segundo, de maior envergadura, foi a Declaração dos Direitos do Homem e do Cidadão, de 1789.

50 Norberto Bobbio, A era dos direitos, p. 19-30.

51 Gilmar Antonio Bedin, Cidadania e nacionalidade: efeitos e perspectivas nacionais - regionais - globais, p. 442. 
Pós-Segunda Guerra Mundial, em que os Estados vencedores procuraram novos ideais para reger as relações do Estado com os indivíduos. Flávia Piovesan destaca o Pós-Segunda Guerra como o momento da reconstrução dos direitos humanos. ${ }^{52}$

A Declaração Universal dos Direitos do Homem teve o grande diferencial de ser integrada na grande maioria dos ordenamentos jurídicos e normas fundamentais dos Estados, o que propiciou a plena eficácia interna, pois a Declaração, por si só, não era dotada de obrigatoriedade vinculante para os Estados.

É o que adverte Wagner Menezes, ao ressaltar que a Declaração não teve origem na Assembleia-Geral da ONU, e portanto não se revestiu do status de um tratado internacional, mas sim de uma resolução. ${ }^{53}$

A Declaração introduziu uma concepção de direitos humanos contemporânea segundo a qual os direitos humanos extrapolam o domínio reservado do Estado, envolvidos que são nos princípios de: universalidade, no sentido de que se aplicam a todos, inclusive aos migrantes; indivisibilidade, ou ausência de hierarquia de direitos, em que certos tipos de direitos não podem ser separados de outros; inalienabilidade, a significar que os direitos humanos não podem ser negados a nenhum ser humano tampouco podem ser renunciados voluntariamente; e a igualdade e não discriminação, noção que conduz à compreensão de que todos os indivíduos são iguais como seres humanos. ${ }^{54}$

É também a partir do século XIX que surgem as organizações internacionais, consideradas como o resultado do amadurecimento das alianças entre reinos, cidades e Estados, que passam a alterar paulatinamente as estruturas da sociedade internacional e construir um espaço de diálogo no contexto das relações internacionais.

A Organização Internacional do Trabalho, criada em 1919, teve como papel preponderante a criação de mecanismos de proteção aos trabalhadores industriais urbanos, mas na verdade reconhece a doutrina que o direito de migração dos trabalhadores só foi

52 Flávia Piovesan, Direitos humanos e o direito constitucional internacional, p. 57.

53 Wagner Menezes, Ordem global e transnormatividade, p. 60.

54 Martin Ruhs, The price of rights: regulating international labor migration, p. 13; Flávia Piovesan, Direitos humanos e direito do trabalho, p. 7. 
valorizado internacionalmente após a Segunda Guerra Mundial, quando os direitos humanos também adquiriram prioridade, sobretudo com a fundação da Organização das Nações Unidas, em 1945, e a Declaração dos Direitos Humanos, de 1948. ${ }^{55}$

A base normativa para uma abordagem internacional dos direitos dos migrantes compreende vários tratados internacionais e regionais que versam especificamente sobre os migrantes.

A Convenção n. 19, da OIT, de 1925, foi o primeiro dos instrumentos internacionais sobre igualdade entre trabalhadores estrangeiros e nacionais, porém restrito aos casos de acidentes de trabalho.

A Convenção entrou em vigor em 08.09.1926, tendo sido ratificada pelo Brasil em 29.05.1956, além de outros 120 países, assegurando ampla proteção aos estrangeiros e aos seus dependentes, sem condição de residência fixa no país. ${ }^{56}$

Entretanto, mesmo entre os países que ratificaram a Convenção n. 19, as vítimas de acidentes ainda enfrentam dificuldades no atendimento prestado pelos serviços de atenção à saúde. Lopes alerta que nem sempre os Estados estão preparados para atender indivíduos que se encontram em situação irregular no país. ${ }^{57}$

A Convenção n. 97, da OIT, de 1939, revisada em 1949, foi ratificada pelo Brasil em 18.06.1965, denominada Convenção sobre os trabalhadores migrantes, objetivou facilitar a entrada, a viagem e a saída dos trabalhadores migrantes, mantendo serviços médicos apropriados e permitindo a remessa das economias dos trabalhadores migrantes ao seu país de origem.

A Convenção somente se aplica a migrantes que ingressaram legalmente nos respectivos Estados-membros. Ruhs aponta para a motivação da Convenção n. 97, voltada a facilitar a migração de um excedente de trabalhadores da Europa para outros países do

55 Ericson Crivelli, Direito internacional do trabalho contemporâneo, p. 60.

56 Arnaldo Sussekind, Convenções da OIT, p. 338.

57 Cristiane Maria Sbalqueiro Lopes, Direito de imigração: o estatuto do estrangeiro em uma perspectiva de direitos humanos, p. 226-227. 
mundo, encorajando esses Estados a assinar tratados bilaterais de recrutamento de força de trabalho.

De fato, a imigração em busca de trabalho foi definida no art. 11 como aquela empreendida por indivíduo que objetiva ocupar um emprego que não seja por conta própria, de modo que somente pelos canais regulares de vinculação do migrante a um contrato ou tratado é que se aplicaria a Convenção, eis que excluídos os trabalhadores transfronteiriços e os profissionais liberais. ${ }^{58}$

A Convenção proíbe, nos arts. $6^{\circ}$ e $9 .^{\circ}$, a expulsão dos migrantes admitidos de maneira permanente, no caso de doença ou acidente que os incapacitem de exercer o respectivo ofício; prevê, ainda, a igualdade de oportunidades e de tratamento dos trabalhadores migrantes em condição regular, relativamente aos trabalhadores nacionais, inclusive no que tange à remuneração, jornada de trabalho, idade de admissão no emprego, trabalho infantil e de mulheres, direitos sindicais, seguridade social, impostos e outros previstos na legislação trabalhista no país. ${ }^{59}$

A Convenção n. 118 da OIT, de 1962, ratificada pelo Brasil em 24.03.1968, é a terceira norma de proteção aos trabalhadores migrantes e aborda a igualdade de tratamento entre nacionais em matéria de assistência prestada pela Previdência Social. Nas disposições do art. 3. é garantido idêntico tratamento que o Estado emprega aos seus nacionais, incluindo o direito do estrangeiro à assistência médica, auxílio-doença, aposentadoria por invalidez, velhice, prestações de maternidade, pensão por morte, seguro-desemprego e salário-família. ${ }^{60}$

Não obstante o caráter protecionista, a Convenção reconhece certas restrições ao estrangeiro, como revelam as disposições do art. $4 .^{\circ}$, ao dispor que os direitos poderão se subordinar a uma condição, por exemplo, de tempo de residência mínima para o ingresso no sistema de proteção e um período máximo de permanência. A Convenção n. 118 foi posteriormente complementada pela Convenção n. 157, que abordou aspectos de preservação de direitos em curso de aquisição ou adquiridos para fins de seguridade social.

\footnotetext{
58 Martin Ruhs, The price of rights: regulating international labor migration, p.14. 
Na esteira das mudanças econômicas e sociais da década de 1960 e início de 1970, que desencadearam a extinção de vários programas de migração a trabalho por parte dos países receptores, foi adotada em 1975 a Convenção n. 143, ainda não ratificada pelo Brasil. $^{61}$

A OIT objetivou complementar a anterior Convenção n. 97, sobre o mesmo tema, estabelecendo a todo Estado-membro o respeito aos direitos humanos fundamentais de todos os trabalhadores migrantes e um nível mínimo de proteção aos indivíduos que tenham imigrado ou que tenham sido contratados de maneira irregular.

A nosso ver, a Convenção n. 143 objetiva propiciar um controle sobre a imigração, confirmado pelo teor do preâmbulo da Convenção, em que a OIT reafirma a sua obrigação de apoiar a realização de programas que facilitem a migração regular, compreendendo, contudo, que é necessário evitar o aumento excessivo e não controlado ou não assistido dos movimentos migratórios, em razão das consequências negativas no campo social e humano. O texto da Convenção n. 143 é extremamente realista, reconhecendo que certas adequações são necessárias para a integração do estrangeiro no país de destino.

Com efeito, na parte que diz respeito à ampla liberdade de escolha do emprego, a Convenção reconhece, no art. 14, que o Estado poderá restringi-la a certos critérios, tais como à condição de que o trabalhador cumpra determinado período mínimo de residência no país, de até dois anos.

Reconhece, ainda, que o exercício da profissão poderá se submeter à aprovação das qualificações profissionais perante as organizações representativas dos empregados e trabalhadores, cujo processo poderá incluir o reconhecimento das qualificações profissionais, compreendendo certificados e diplomas obtidos no estrangeiro. ${ }^{62}$

61 Firmino Alves Lima registra, em sua obra Teoria da discriminação nas relações de trabalho, p. 285, a tentativa do Ministério do Trabalho, por meio de sua Comissão Tripartite de Relações Internacionais, no encaminhamento da Convenção para aprovação e ratificação pelo Congresso Nacional, ainda em tramitação.

62 Disponível em: <http://www.direitoshumanos.usp.br/index.php/OIT-Organização-Internacional-doTrabalho/convencao-no-143-da-oit-relativo-as-migracoes-em-condicoes-abusivas-e-a-promocao-da- 
Após mais de uma década de negociações, é adotada, pela Assembleia-Geral da ONU, a Convenção sobre a proteção dos Direitos de todos os Trabalhadores Migrantes e os membros de suas famílias em 18.12.1990, entrando em vigor em $1 .^{\circ} .07 .2013 .{ }^{63}$

Esse instrumento incorpora as Convenções da OIT n. 97 e n. 143 e completa o conjunto de direitos dos migrantes, incluindo aqueles indivíduos que vivem e/ou trabalham ilegalmente fora de seus respectivos países de origem, destacando-se por apresentar um verdadeiro guia para definir as políticas nacionais e internacionais de migração baseado nos direitos humanos.

Adicionalmente, garante aos trabalhadores migrantes o necessário acesso ao Poder Judiciário e ao devido processo legal, caso vitimados por violações aos seus direitos, como adiante demonstraremos.

O principal objetivo da Convenção é propiciar a todos os trabalhadores migrantes usufruírem de seus direitos humanos, independentemente de seu estatuto jurídico.

Não é por outra razão que a Convenção se baseia em normas jurídicas trabalhistas internacionais em vigor, bem como nas convenções relativas ao trabalho escravo ou em condição análoga.

O texto da convenção remete ainda para as disposições da Convenção da Unesco que trata da luta contra a discriminação em matéria de educação. Outros instrumentos internacionais serviram de inspiração à Convenção, dentre os quais destacamos:

- Convenção internacional sobre a eliminação de todas as formas de discriminação racial;

- Pacto internacional sobre os direitos econômicos, sociais e culturais;

igualdade-de-oportunidades-e-de-tratamento-dos-trabalhadores-migrantes.html>. Acesso em: 10 mar. 2013.

63 Disponível em: <http://www.ilo.org〈ilolex\spanishไnewratframeS.htm>. Acesso em: 26 nov. 2012. 
- Convenção sobre a eliminação de todas as formas de discriminação contra as mulheres;

- Convenção contra a tortura e outras penas ou tratamento cruéis, desumanos ou degradantes;

- Convenção sobre os direitos da criança;

- Declaração do quarto congresso das Nações Unidas para a prevenção do crime e o tratamento de delinquentes.

A Convenção foi dividida em nove capítulos que dispõem sobre seu escopo e definições; a não discriminação do migrante em relação aos seus direitos; os direitos humanos dos trabalhadores migrantes em situação irregular, assim como de seus familiares; outros direitos dos trabalhadores migrantes em situação regular e de seus familiares; as regulamentações aplicáveis a categorias especiais de trabalhadores migrantes e seus familiares; a promoção de condições de segurança, igualdade, humanidade e legalidade para os trabalhadores migrantes e seus familiares, além de provisões gerais sobre a aplicação da convenção e provisões finais.

A seguir, apresentamos as disposições mais relevantes da Convenção.

Definição do trabalhador migrante:

Conforme o art. 2. ${ }^{\circ}$, Parte I, inciso primeiro, o trabalhador migrante é definido, para fins de aplicação da Convenção, como "a pessoa que será, que é, ou que tenha sido contratada para o exercício de uma atividade remunerada, num Estado estrangeiro”.

Categorias de trabalhadores migrantes:

O inciso segundo do mesmo dispositivo apresenta oito distintas categorias de migrantes:

i. Frontier worker, mais conhecido como o trabalhador fronteiriço, que se revela pelo indivíduo que habita cidades da fronteira, normalmente 
domiciliado no país em que possui nacionalidade, mas exercendo seu trabalho no país vizinho, retorna diária ou semanalmente ao país de origem.

ii. Seafarer: trata-se do pescador e dos trabalhadores migrantes empregados em navio cuja bandeira é de Estado estrangeiro.

iii. Worker on a offshore installation: expressão que identifica o trabalhador empregado em instalação costeira, sob jurisdição de outro país que não é seu.

iv. Itinerant worker: refere-se ao trabalhador migrante que deixa seu país de origem por curtos períodos de tempo, para atender viagens necessárias ao cargo que ocupa;

v. Project-tied worker: a expressão define o trabalhador migrante admitido em país estrangeiro por período determinado, para a execução de projeto específico, a ser realizado em nome de seu empregador.

vi. Specified-employment worker: a expressão compreende quatro subclassificações, a saber:

vii. trabalhador migrante transferido por seu empregador para outro país com a finalidade de executar determinada tarefa de duração temporária;

viii. trabalhador migrante contratado em seu país de origem com a específica determinação de migrar temporariamente para a realização de determinada tarefa ou projeto em país estrangeiro, que exige especialização profissional, comercial ou técnica.

ix. trabalhador migrante designado para uma transferência internacional por seu empregador, para o desempenho de atividade de curta duração;

x. trabalhador migrante que deve se retirar do país estrangeiro onde está empregado a título provisório, motivado pela finalização do prazo de seu visto de trabalho ou por não serem mais necessários os seus serviços

xi. Self-employed worker: define o trabalhador migrante que exerce atividade remunerada sem contrato de emprego, obtendo rendimento mediante 
contratos de prestação de serviços temporários, ou como autônomo, assim reconhecido pela legislação do país estrangeiro em que se encontra ou por acordos bi ou multilaterais.

Esse é o rol de trabalhadores a que se destina a Convenção. Vale anotar que o art. 3. ${ }^{\circ}$ da Convenção exclui a aplicação dos direitos nela previstos aos seguintes trabalhadores:

- Pessoas enviadas ou empregadas por organizações internacionais, ou em missões oficiais, cujo vínculo empregatício seja regulado por acordos ou convenções internacionais;

- Pessoas enviadas por Estados que realizam programas de desenvolvimento ou de cooperação em Estados estrangeiros;

- Investidores;

- Apátridas e Refugiados;

- Estudantes e Estagiários;

- Marinheiros e empregados de instalações costeiras, aos quais não tenha sido concedida licença para residir, mas que tenham sido contratados para exercer atividade remunerada no Estado da contratação.

Retomando os direitos previstos nessa Convenção, destacamos os seguintes: Direito à preparação para a migração: $O$ art. 33 da Convenção Internacional sobre a Proteção dos Direitos de Todos os Trabalhadores Migrantes e dos Membros das suas famílias (CIDM) preconiza que os Estados-membros devem instituir medidas adequadas para garantir que os trabalhadores migrantes e os membros das suas famílias recebam informações acerca dos direitos que lhe são reconhecidos pela Convenção. A informação deve ser fornecida gratuitamente e em uma língua que compreendam, e deve conter instruções sobre todas as condições exigidas para a sua admissão no país de destino e, bem assim, as autoridades a que devem dirigir-se para o cumprimento das exigências para sua admissão. 
Quanto à Prevenção à discriminação, o inciso I do art. 24 da CIDM estabelece o direito à não discriminação, garantindo que todos os trabalhadores migrantes sejam beneficiados de um tratamento não menos favorável que aquele concedido aos nacionais em matéria de emprego e de retribuição e outras condições de trabalho e de emprego.

A instituição dessa previsão objetiva coibir os Estados-membros de adotarem normas jurídicas e administrativas que fomentem o tratamento dos migrantes como mão de obra complementar, atribuindo-lhes tarefas que não interessam aos nacionais. Assim, os Estados são conclamados a reformular normas internas que, por exemplo, obriguem os trabalhadores a permanecerem em determinadas regiões, bem como autorizarem a práticas de salários desiguais para trabalhos idênticos aos nacionais.

No que tange às expulsões arbitrárias e direito ao regresso voluntário, os arts. 22 e 56 da CIDM abordam a questão da expulsão e da expulsão arbitrária. O inciso I do art. 22 proíbe expressamente quaisquer medidas de expulsão coletiva. A decisão de expulsão do trabalhador migrante deverá ser necessariamente tomada por uma autoridade competente e somente deverá concretizar-se quando justificada por razões definidas na legislação nacional. Adicionalmente, estabelece que o indivíduo tem o direito de se opor judicialmente à expulsão, salvo se incentivada por motivos de segurança nacional.

Quanto ao direito ao regresso voluntário, os trabalhadores migrantes têm garantido o direito a regressar ao país de origem, se assim o desejarem. Ao regresso devem dispor de serviços de orientação e ter a possibilidade de se utilizarem dos conhecimentos que adquiriram no estrangeiro.

Há, ainda, a previsão de medidas para impedir o tráfico ilegal. Ciente de que são necessárias barreiras introduzidas pelos Estados para impedir a entrada de mão de obra ilegal, o art. 68 da CIDM conclama os Estados-membros a cooperarem entre si para prevenir e eliminar os movimentos e o trabalho ilegal de trabalhadores migrantes clandestinos em situação irregular. A Convenção solicita a todos os Estados-Partes que adotem medidas para reprimir a disseminação de movimentos ilegais ou clandestinos e impor sanções eficazes a pessoas, grupos ou entidades que organizem, realizem ou participem de tais movimentos, ou recorram à violência. 
Quanto à educação dos migrantes e suas famílias, várias organizações internacionais têm dedicado atenção especial às necessidades educacionais dos filhos dos trabalhadores migrantes, dentre elas citamos a Comissão das Nações Unidas para o Desenvolvimento Social, a Organização das Nações unidas pra a Educação, Ciência e Cultura (Unesco), além do Fundo das Nações Unidas para a Infância (Unicef). Assim, quando a Convenção trata de aspectos de educação dos filhos dos migrantes, abrange globalmente os direitos humanos e as liberdades fundamentais de uma forma flexível de modo que se permite aplicar em todo o mundo.

A aplicação da Convenção dos trabalhadores migrantes, nos termos do art. 72, se dará mediante a instituição de um comitê para a proteção dos direitos dos trabalhadores migrantes e suas famílias com o fim de examinar a aplicação da Convenção, após a sua ratificação por pelo menos 20 Estados. O comitê deve ser composto por dez peritos independentes, número que será elevado para 14 após a 41. a ratificação. Os membros do comitê serão eleitos por voto secreto pelos Estados-Partes e exercerão suas funções por um período de quatro anos.

Os Estados-Partes que ratificarem a Convenção se comprometem a apresentar relatórios sobre as medidas que adotaram para efetivar a aplicação das disposições da Convenção. Os relatórios devem ser elaborados a partir do ano seguinte à data de entrada em vigor da Convenção para o Estado-Parte interessado e, em seguida, de cinco em cinco anos. Os relatórios devem indicar as dificuldades internas que afetam a aplicação da Convenção, além de conter obrigatoriamente informações sobre os fluxos migratórios. O comitê se encarregará de analisar os relatórios e transmitir suas observações ao EstadoParte interessado.

Conforme prevê o art. 76 da Convenção, qualquer Estado-Parte poderá declarar que reconhece a competência do Comitê para receber e apreciar comunicações de um Estado-Parte, invocando o não cumprimento, por outro Estado, das obrigações decorrentes da Convenção. As comunicações só podem ser recebidas se forem provenientes de um Estado-Parte que tenha reconhecido a competência do Comitê.

Nos termos do art. 77, qualquer Estado-Parte pode declarar que reconhece a competência do Comitê para receber e examinar comunicações apresentadas por pessoas 
sujeitas à sua jurisdição, ou em nome dessas pessoas, invocando a violação por esse Estado dos direitos previstos na Convenção.

Retomando o texto da Política Nacional de Imigração e Proteção do Trabalhador Migrante, vale destacar, dentre seus princípios e diretrizes:

i. a vedação a procedimentos de admissão discriminatórios;

ii. o dever do Estado em prover igualdade de oportunidades e de tratamento aos estrangeiros em relação aos cidadãos brasileiros;

iii. o direito à educação;

iv. a transformação do delito de migração irregular em infração administrativa e não sujeita à sansão penal;

v. o direito à reunião familiar;

vi. o enfrentamento à discriminação, à xenofobia e ao racismo em relação aos migrantes.

Dentre os direitos assegurados tanto a trabalhadores regulares quanto a irregulares, se destacam:

- Direito à vida (art. 9);

- Proteção contra o trabalho forçado (art. 11);

- O direito de não ter os documentos de identidade confiscados (art. 21);

- O direito de igualdade de tratamento concernente à remuneração e condições de emprego e seguridade social (arts. 25 e 27);

- A liberdade de participar de reuniões e de atividades sindicais (art. 26). 
Dentre os direitos adicionais garantidos aos migrantes legalizados, destaca-se o direito de escolher livremente uma atividade remunerada, contudo somente após cinco anos de residência no país de destino (art. 52).

Na prática, todavia, a ratificação da convenção de 1990 foi frustrante. Apesar de ter sido adotada há mais de 20 anos, cerca de 50 países a ratificaram até a presente data, cuja grande maioria é predominantemente composta de nações emissoras, muito mais do que receptoras de trabalhadores migrantes. O Brasil está no rol dos países que ainda não a ratificaram. ${ }^{64}$

\section{Quais são os obstáculos à ratificação da Convenção de 1990?}

A constatação de que no conjunto dos países que não ratificaram a Convenção de 1990, assim como o Brasil, se identificam muitos países que assinaram outros tratados relevantes para a proteção dos direitos humanos torna ainda mais difícil entender a razão pela qual não houve adesão significativa a essa Convenção.

Dados oficiais divulgados pelas Nações sobre a ratificação de tratados sobre direitos humanos no período entre 1965 a 2011 dão conta de que 200 países ratificaram a Convenção Internacional sobre a Eliminação de Todas as Formas de Discriminação racial. Cerca de 175 países ratificaram a Convenção Internacional Sobre Direitos Civis e Políticos e a Convenção contra Tortura e Outras Formas de Tratamento Cruel ou Degradante, e pelo menos 150 países assinaram a Convenção sobre os Direitos de Pessoas Portadoras de Deficiências. ${ }^{65}$

Os dados sugerem que os países que não ratificaram a Convenção de 1990 incorporaram direitos humanos em seus ordenamentos internos, porém, estranhamente, relutam em aplicar esses mesmos direitos aos estrangeiros que vivem em seus territórios.

64 Para acompanhar a lista de países que ratificaram a convenção, veja: 〈http://www2.ohchr.orglenglishl〉. Acesso em: 2 fev. 2013.

65 Disponível em: <http://treaties.un.org\Pages|Treaties.aspx?id=4\&subid=A\&Lang=en>. Acesso em: 20 dez. 2011. 
Alguns estudos acadêmicos se dedicaram à investigação do tema e identificaram pelo menos três obstáculos. Patrick Taran identifica como primeiro obstáculo a falta de familiaridade e de compreensão sobre os termos técnicos da sociedade civil, organizações e de órgãos estatais que seriam os responsáveis pela efetividade dos direitos ali assegurados. ${ }^{66}$

O segundo obstáculo levantado por Ruhs é uma consequência do primeiro, ou seja, em razão da complexidade da Convenção, a ratificação em muitos países impactaria em revisar e possivelmente alterar significativamente o corpo de leis e políticas internas. ${ }^{67}$

Um terceiro obstáculo apontado por diversos doutrinadores, dentre os quais Hume e Niese, é atribuído aos impactos adversos na economia e à pressão social dos cidadãos nacionais. Nossos estudos empíricos, desenvolvidos no próximo capítulo, tratam de confirmar se os obstáculos estão relacionados a esses fatores, ou, como é o nosso sentir, aos custos da garantia desses direitos. ${ }^{68}$

A igualdade de tratamento entre nacionais e estrangeiros é ainda tema de Convenção específica da OIT, que trata do tema da Previdência Social. Trata-se da Convenção n. 118, mediante a qual os países-membros se comprometem em conceder aos nacionais de qualquer outro membro para o qual a convenção estiver em vigor, o mesmo tratamento que os seus próprios nacionais, em qualquer ramo da previdência social. ${ }^{69}$

Determinadas prestações poderão ficar condicionadas a uma condição de residência por um período mínimo que poderá variar, conforme o caso: a) seis meses, imediatamente antes do pedido da prestação, no que concerne às prestações de maternidade e seguro-desemprego; b) cinco anos consecutivos, imediatamente antes do pedido de prestação no que concerne às aposentadorias por invalidez, ou antes, no que concerne às

66 Patrick Taran é um dos especialistas sênior em imigração da Organização Internacional do Trabalho e seus apontamentos aqui resumidos estão disponíveis em: <http://migrationcentralasia.itcilo.org/ en/project/capacity-is-built-and-stakeholders-trained/regional/tripartite-launch-seminar-on-migration-fordevelopment-and-regional-isik-kul-dec08/day-1/Patrick-Taran-An-overview-of-global-migration.doc/ view>. Acesso em: 21 dez. 2011. Martin Ruhs, The price of rights: regulating international labor migration, p. 18.

68 S. Hume e J. Niese, Ratifying the UM Migrant Workers Convention: Current Difficulties and Prospects, p. 393-399.

69 Disponível em: 〈http://www.oitbrasil.org.br/note/476〉. Acesso em: 27 set. 2013. 
pensões por morte; e c) dez anos após a idade de dezoito anos - dos quais cinco consecutivos podem ser exigidos - imediatamente antes do pedido de prestação - no que concerne à aposentadoria por velhice.

A perspectiva histórica lamentavelmente nos revela que a decisão de inclusão do migrante continua como uma decisão política e restritiva, intimamente ligada à cidadania e consequentemente sujeita à aplicação do código binário de inclusão/exclusão.

Nesse contexto, a doutrina mais moderna entende que esse código binário conduz a três critérios básicos para as políticas migratórias: ${ }^{70}$

i. Critério comunitarista;

ii. Critério utilitarista;

iii. Critério constitucionalista.

Sob o critério comunitarista, a inclusão do migrante é pautada pelo parentesco, que permite o ingresso dos mais próximos, em geral a família e os dependentes, rejeitando-se a criação de grandes espaços atomizados. A dimensão comunitarista impõe uma barreira à inclusão de que não são comunitariamente próximos, seja porque são de raça diferente, seja porque seguem crenças diferentes ou, ainda, porque não partilham da mesma identidade histórica.

O critério utilitarista funciona sob um código de custo/benefício, sob o qual a sociedade se concebe como um grande clube filiado no Estado de bem-estar, reservando apenas aos seus incluídos as vantagens de associação, enquanto os estrangeiros disputam parcos e restritos direitos de ingresso temporário ao "clube".

Sob o critério constitucionalista, a ideia de inclusão se assenta no reconhecimento de sujeitos de direitos e princípios constitucionais, como a dignidade da pessoa humana, os direitos fundamentais, o estado de direito, a igualdade, a solidariedade ea justiça. Nas palavras de Canotilho "só tomando em conta estes princípios se pode

70 Nesse sentido, J.J. Canotilho, Enquadramento jurídico da imigração, p. 154, com apoio em Jean Marc Ferry, La Question de l'État Européen; Wilfried Brugger, Liberalismus, Pluralismus, Kommunitarismus. 
decidir, em termos constitucionalmente aceitáveis, como proceder à inclusão dos outros, designadamente dos migrantes". ${ }^{71}$

Nessa ótica, é forçoso reconhecer que o universalismo e o internacionalismo dos direitos humanos não se podem render a um conceito de cidadania com feição local e excludente. É preciso reconhecer que os Estados não podem se apropriar de direitos construídos e reconhecidos internacionalmente, de forma a restringi-los ou diferenciá-los na situação que envolva o trabalhador migrante.

A tensão entre cidadania e a globalização necessita ser levada em conta no estudo de uma nova ordem para a migração.

Enquanto a globalização é caracterizada pela "intensificação das relações em escala mundial, que ligam localidades distantes de tal maneira que acontecimentos locais são modelados por eventos ocorrendo muitas milhas de distância e vice-versa", 72 o conceito de cidadania ainda expressa os direitos políticos que ligam um indivíduo ao Estado, no sentido de permitir votar, ser votado, participar como membro ativo da sociedade, submetendo-se à soberania do Estado.

Para muitos autores, a soberania do Estado está sendo colocada em xeque. Lewandowski, por exemplo, faz um resumo das teorias atuais sobre o tema, advertindo que, apesar da inegável ingerência do Estado na vida dos cidadãos, há o reconhecimento de que o seu poder está em constante declínio, em grande parte em virtude da falha do próprio Estado em promover, de forma eficiente, a promoção de serviços essenciais, sendo esta a principal causa da perda gradual da legitimidade e do respeito do Estado. ${ }^{73}$

Nesse cenário, as regras que definem a cidadania também se mostram desacreditadas e ultrapassadas. Ainda hoje predominam dois mecanismos para adquirir e transmitir a cidadania. Como destaca Carens, o ius soli representa literalmente o direito ao solo, mediante o qual ou indivíduo obtém a cidadania pelo fato de ter nascido no território de determinado país, e o ius sanguinis, que se poderia traduzir como do direito de sangue,

71 J.J. Canotilho, Enquadramento jurídico da imigração, p. 154.

72 Anthony Giddens, As consequências da modernidade, p. 69.

73 Enrique Ricardo Lewandowski, Globalização, regionalização e soberania, p. 255. 
por meio do qual a cidadania é transmitida com base na descendência de pais que possuam a cidadania de determinado país.

$\mathrm{Na}$ atualidade, a maioria dos países adota o ius soli como fonte formal e uma versão do ius sanguinis ao nascimento dos filhos dos migrantes com residência permanente. Estados Unidos e Canadá são exemplo dessa combinação. ${ }^{74}$

A nosso ver, é preciso tratar a cidadania como um pilar do Estado que, ao lado de princípios fundamentais, deve funcionar como um fio condutor atribuindo valor para a elaboração leis que regulem a migração de forma harmônica com o princípio da dignidade da pessoa humana.

Tratar a cidadania como um princípio permite atribuir carga valorativa que observamos ser necessária ao tema da migração. Nesse sentido, nos valemos do conceito de princípio de Bandeira de Mello, como

[...] mandamento nuclear de um sistema, verdadeiro alicerce dele, disposição fundamental que se irradia sobre diferentes normas, compondo-lhe o espírito e servindo de critério para sua exata compreensão e inteligência, exatamente por definir a lógica e a racionalidade do sistema normativo, no que lhe confere a tônica e lhe dá sentido harmônico. ${ }^{75}$

Hobsbawm oferece enorme contribuição à compreensão dos efeitos da mobilidade sobre os conceitos mais antigos de nação e nacionalismo. Partindo da observação feita por Benedict Anderson, de que o documento de identidade do século XXI deixou de ser a certidão de nascimento do Estado nacional, passando para o passaporte, o autor explora o novo significado de cidadania em Estados nos quais uma grande parte de seus habitantes está ausente do território nacional e outra porção igualmente relevante de residentes é formada por estrangeiros cujos direitos são inferiores aos dos cidadãos nacionais.

Aponta, ainda, Hobsbawm para o fator xenofobia associado a uma crise de identidade nacional em que as novas formas de informação dissolvem as grandes

74 Joseph H. Carens, The ethics of immigration, p. 35.

75 Celso Antônio Bandeira de Mello, Curso de direito administrativo, p. 771-772. 
identidades como a do Estado, convertendo-as em identidades grupais ou particulares não nacionais, que em grande medida diminuem a legitimação do Estado nacional para os que vivem no seu território. ${ }^{76}$

Soares destaca os pontos centrais da inserção do estrangeiro na temática dos direitos humanos, de tal forma que esses direitos "são oponíveis contra o Estado". Mais precisamente em relação ao Estado liberal, destacando a contradição de se ter um estado de democracia moderna convivendo com a exacerbação de um nacionalismo xenófobo, conducente a atitudes cada vez mais hostis em relação aos estrangeiros. ${ }^{77}$

A cidadania globalizada indica, em nosso sentir, que o Estado deve desenvolver políticas positivas, compatíveis com a visão do tema da migração como um fenômeno social a ser tratado ativamente, de forma colaborativa, mediante diálogo entre Estados emissores e receptores do fluxo migratório, com medidas efetivas e protetivas, em vez de um problema a ser combatido, como questão de segurança nacional.

Como diz Comparato, devemos indagar sobre "o advento de uma nova ordem civilizacional". O autor demonstra que desde a idade moderna a humanidade vem se orientando sempre mais em relação ao futuro do que ao passado, em rumo "a um mundo mais justo, em que o ideal da felicidade, que sempre inflamou os corações, possa enfim ser alcançado pelo maior número possível de pessoas".

A matriz dessa nova civilização mundial humanista tem seu embrião na consciência da dignidade da pessoa humana e que após sucessivas etapas de gestação histórica, finalmente, é reconhecida como um estado que coincide com a afirmação dos direitos humanos e dos mecanismos para as suas respectivas garantias. ${ }^{78}$

Nessa perspectiva, é urgente que lancemos um olhar menos economicista e mais humanístico à globalização de modo a promover um pensamento de unificação interdisciplinar, abandonando a ideia de que existe uma única e exclusiva definição restrita da cidadania e dos direitos a ela relacionados.

76 Eric Hobsbawm, Globalização, democracia e terrorismo, p. 90-91.

77 Guido Fernando Silva Soares, Os direitos humanos e a proteção dos estrangeiros, p. 169-204.

78 Fábio Konder Comparato, A civilização capitalista: para compreender o mundo em que vivemos, p. 291. 
A construção dos direitos humanos e os movimentos de mundialização do capital inegavelmente reclamam que a soberania dos Estados ceda espaço à influência decisória dos organismos internacionais, respeitadas, evidentemente, as especificidades de cada Estado.

A questão da cidadania global torna necessário levar em conta a necessidade de uma sociedade mais solidária e pluralista, que consiga superar as tensões, mediante diálogo desvinculado dos ordenamentos estatais.

Em última análise, concordamos com Santos, no sentido de que os Estados modernos figuram como atores globais e são, em última análise "anti-homem e anticidadão, facultando a possibilidade da existência de um cidadão do mundo, ainda que condicionado às realidades locais", que nunca serão esvaziadas, mas sim positivamente relativizadas, harmonizadas para o bem comum. ${ }^{79}$

Assim, a nossa proposta seguinte é promover um debate sobre os direitos dos migrantes, que envolve integração da igualdade e da ética nas políticas nacionais de migração a trabalho, como forma de relativizar a forte restrição que a cidadania impõe sobre os migrantes.

\subsection{Igualdade e ética nas políticas migratórias}

Nos argumentos até aqui expostos, apresentamos os pilares da construção dos direitos humanos e procuramos identificar a sua aplicação ao fenômeno da migração a trabalho.

Este tópico introduz e delimita os fios condutores dos quais nos valemos para o desenvolvimento do próximo capítulo, sobre as políticas nacionais e internacionais de imigração a trabalho.

79 Milton Santos, Por uma outra globalização: do pensamento único à consciência universal, p. 131. 
Qualquer contribuição no campo das políticas de imigração, à luz do direito do trabalho, implica alinhar conceitos fundamentais do Direito do Trabalho. Portanto, a igualdade e a ética dão pleno suporte ao debate que desejamos empreender:

\section{Qual é a política migratória trabalhista possível?}

Poderão surgir respostas variadas e complexas, a depender do âmbito em que se estuda o fenômeno da imigração.

No conjunto de propostas possíveis para a análise e a avaliação das políticas migratórias trabalhistas, a igualdade e a ética têm se constituído palavras-chave de muitos debates doutrinários.

Isso se deve em primeiro lugar porque se constituem em princípios essenciais ao enfrentamento de questões que na sua base envolvem fundamentalmente o conjunto de direitos que estamos dispostos a conceder aos estrangeiros que desejam ingressar e fazer parte da nossa comunidade.

Deveali cita o princípio da sinceridade das leis trabalhistas como um critério que deve inspirar o legislador na aprovação das normas trabalhistas. ${ }^{80}$

Em segundo lugar, igualdade e ética inspiram a ciência do direito do trabalho, cujos efeitos sobre o trabalhador migrante são de tal forma relevantes que vão definir, em última instância, se ele poderá permanecer no território do país que escolheu ingressar ou se, por falta de meios de subsistência ou de comprovação de relação de emprego formal, será impedido de cumprir com os requisitos de permanência estabelecidos em muitas políticas de migração nacional.

A igualdade, de acordo com nossos dicionários, provém do latim aequalitas, indica semelhança de duas coisas, uma uniformidade entre todos os elementos que constituem duas ou mais coisas.

80 Mario L. Deveali, apud Américo Plá Rodrigues, Princípios de direito do trabalho, p. 14. 
No sentido jurídico do conceito, a igualdade não pode ser tomada rigorosamente nesse sentido, pois temos que reconhecer que não é possível exigir um realismo absoluto. ${ }^{81}$

Assim, a igualdade entende-se civil, política e social. A civil e a política compreendem a igualdade perante a lei civil, comercial, penal e administrativa. Há, contudo, restrições ao pleno exercício relativas ao estrangeiro, uma vez que existem certos cargos em que a condição da nacionalidade brasileira é requerida. Os estrangeiros não podem exercer cargos eletivos para a administração pública ou para a constituição do governo.

Assentada nessa diferenciação de pessoas em razão da nacionalidade, o migrante sofre sérias limitações, inclusive em relação àqueles que ingressaram e se mantêm em situação jurídica regular no país.

A igualdade social, no contexto da migração a trabalho, se imbrica, a nosso ver, com os direitos humanos denominados de segunda geração, que abrangem a titularidade dos mesmos direitos garantidos aos nacionais em relação a direitos econômicos e sociais, como o acesso a um trabalho digno, remunerado nos mesmos patamares pagos aos nacionais, com igualdade de condições, acesso a benefícios trabalhistas e à seguridade social. Esses direitos vieram consagrados na Declaração Universal dos Direitos do Homem e do Cidadão, nos arts. 22 a 27.

O tema da igualdade na visão de Hannah Arendt se coloca como a garantia de ter direitos. De modo que poderá ser plenamente exercida mediante ação conjunta dos meios de organização da comunidade política. Assim, a igualdade, para Arendt é concebida como o direito de viver entre iguais, no sentido de medidas que procurem suprir diferenças. $^{82}$

Estudar a migração à luz do debate sobre a igualdade entre nacionais e estrangeiros atrai, como diz Lopes, a concepção da igualdade como ideal a ser atingido, e que implicaria a revisão das estruturas sociais e reformas com o objetivo de eliminar

\footnotetext{
81 De Plácido e Silva, Vocabulário jurídico, p. 406.

82 Hannah Arendt, Los orígenes del totalitalismo, p. 380.
} 
hierarquias e subordinações que impedem aos migrantes o acesso aos bens e direitos concedidos aos cidadãos nacionais. ${ }^{83}$

Essa premissa, conquanto verdadeira, em certa medida reduz o debate a uma única solução, que seria a garantia da igualdade plena e absoluta entre cidadãos nacionais e estrangeiros. A dificuldade deste debate reside no fato de que a própria Convenção sobre os Direitos dos Estrangeiros de 1990 admite certas diferenças entre estrangeiros e cidadãos em questões de importância social, inclusive no que diz respeito aos direitos trabalhistas.

$\mathrm{Na}$ verdade, nem mesmo a Declaração Universal dos Direitos do Homem garante ao estrangeiro o direito de entrar no território do país do Estado do qual não é nacional.

Há um paradoxo entre o art. 13, n. 2, da Declaração que dispõe sobre o direito de toda pessoa abandonar o país em que se encontra, incluindo o seu, e o direito de regressar ao seu país. Da mesma forma, o art. 12, n. 2, do Pacto Internacional de Direitos Civis e Políticos garante o direito de sair livremente de qualquer país, e o direito de regressar no seu próprio país.

Essas disposições carregam a incoerência de permitir o direito de saída, mas não o direito de ingresso em país do qual não é nacional.

A desigualdade jurídica entre nacionais e estrangeiros é analisada por Cahali justamente sob a prevalência de que todo Estado possui de proceder em relação ao estrangeiro nos limites do direito das gentes.

Assim, apesar de os direitos dos estrangeiros se fundarem na ideia de que o Estado atuará com respeito às obrigações que contraiu por meio de tratados ou convenções, o autor ressalta que o direito internacional não obriga o Estado a autorizar ao estrangeiro a aquisição de todos os direitos privados. ${ }^{84}$

83 Cristiane Maria Sbalqueiro Lopes, Direito de imigração: o Estatuto do Estrangeiro em uma perspectiva de direitos humanos, p. 88-89.

84 Yussef Said Cahali, Estatuto do Estrangeiro, p. 362-363. 
A lição de Oscar Ermida Uriarte permite esclarecer a confusão que se dá quando buscamos identificar a igualdade formal e abstrata, segundo a qual "todos somos iguais perante a lei”, no estudo de fenômenos e relações entre desiguais.

Ao explicar a aplicação do direito do trabalho, que evidentemente também deve proteger o migrante, o autor esclarece que, diferente do direito civil clássico, o direito do trabalho atua na igualdade material, procurando compensar as diferenças que naturalmente existem entre pobres e ricos, entre poderosos e débeis, entre possuidores e despossuídos. ${ }^{85}$

A concepção de um modelo de igualdade voltado para as questões migratórias deve levar em conta características que podem justificar medidas e distribuição de recursos que objetivam corrigir desigualdades.

Essa concepção é defendida por Lima ao analisar igualdades e diferenças em sua teoria da discriminação, na defesa de uma distribuição de recursos de modo a compensar necessidades de determinado grupo, de tal modo a tornar justa uma distribuição desigual de recursos pautada na diferenciação presente no fenômeno social sob análise. ${ }^{86}$

O problema da igualdade entre nacionais e migrantes, em certa medida, cede espaço para o combate ao dumping social. Nesse aspecto, Peres identifica a prevalência do debate sobre a harmonização de normas nos processos de integração regional e comunitária e até mesmos nas cláusulas sociais e a sua inserção como critério de concorrência internacional na Organização Mundial do Comércio. ${ }^{87}$

Essa meta está constantemente em tensão com a cidadania. Como vimos no tópico anterior, a cidadania insiste em se colocar como um privilégio superior, que traz de arrasto a distinção, a exclusão do outro.

Nessa perspectiva, o Relatório Mundial de Migrações identifica um enorme desafio para a humanidade, que consiste em impor ao Estado, que usufrui da força de

85 Oscar Ermida Uriarte, prefácio à obra de Firmino Alves Lima, Teoria da discriminação nas relações de trabalho, p. XII e XIII.

86 Firmino Alves Lima, Teoria da discriminação nas relações do trabalho, p. 31.

87 Antonio Galvão Peres, Contrato internacional de trabalho: novas perspectivas, p. 59. 
trabalho do migrante, a responsabilidade em não afrontar os direitos internacionais, assumindo o compromisso político de respeitar as leis internacionais de migração. ${ }^{88}$

Há uma reconhecida assimetria de tratamento à questão da entrada e da saída de trabalhadores. Lima confirma nossa visão de que o direito de ingresso e de permanência em determinado Estado não pertence ao indivíduo, sofrendo uma restrição intensa nas políticas migratórias de muitos Estados, que valorizam demasiadamente o seu direito de soberania, sob o qual se impõe a entrada em seu território como uma mera expectativa de direito. ${ }^{89}$

Nessa perspectiva, contribui com nosso estudo compreender em que consistem as práticas discriminatórias das quais o trabalhador migrante pode ser vítima. A Convenção n. 111 da OIT apresenta um conceito descritivo do que vem a ser a discriminação no campo trabalhista em seu art. $1^{\circ}$, que procura proibir qualquer tratamento que objetive distinguir, excluir ou dar preferência em matéria de acesso ao emprego ou profissão, com base na raça, cor, sexo, religião, ascendência nacional ou origem social.

Em conclusão, a igualdade que pensamos aplicar ao trabalhador migrante é da igualdade compensatória e protetora, que entendemos deva ser uma meta para os Estados, procurando reduzir a desigualdade.

Dito isso, passamos à análise de ética aplicada às políticas migratórias. Como visto, há enorme preponderância da soberania dos Estados para a definição das políticas de imigração. As forças desencadeadas pelos Estados receptores se pautam em justificativas de diversas naturezas, que procuraremos explorar ao longo deste trabalho, buscando encontrar caminhos para estabelecer um diálogo à luz da ética.

A ética no contexto da imigração a trabalho foi, assim, a escolha natural, uma vez que o fenômeno da migração diz respeito às pessoas. Logo, a ética figura como o recorte ideal para lançar luzes sobre a tensão existente entre pessoas e nações.

88 O Relatório em comento propõe uma abordagem coerente do tema migratório, reforçando que os Estados devem demonstrar respeito às disposições dos quadros legais e normativos que se impõem em favor dos migrantes, especialmente os sete tratados básicos sobre direitos humanos das Nações Unidas. 
No entanto, de pronto reconhecemos que a ética não admite um diálogo fácil, dada a complexidade filosófica com a qual se imbrica, sobretudo quando nos atrevemos a utilizá-la para explicar tema de enorme relevância para a humanidade, que é migração de pessoas.

Assim, traçamos um norte com inspiração nas lições de Barros Filho e Pompeu, que situa a ética com apoio na compreensão da justiça e do justo: ${ }^{90}$

Justiça não é objetivamente definida em leis, mas relacionalmente definida por tomadas de posição havidas mais em função de um sentimento do que da razão. Posicionamos-nos em favor do mais fraco sem nos darmos conta da regra ou raciocínio que praticamos para isso. [...] Simplesmente o fazemos. Tomamos posição a partir do que sentimos justo e nos aliamos à massa dos que lutam por manter um mundo bom. Com sua beleza e bondade confundidas com a ordem que percebemos e à qual nos acostumamos. Ordem da vida viável.

A ética é definida como a ciência da moral. ${ }^{91}$ Uma referência sobre a ética aplicada à migração internacional a trabalho é a ética humanista, pontuada por Isabel Estrada Carvalhais nas liberdades fundamentais, como a liberdade de ação (ingressar, permanecer, sair), e a ética que defende direitos tidos como fundamentais à dignidade humana durante o período de permanência do indivíduo no território de país que não é o seu. $^{92}$

A condição humana, todavia, é complexa, e, como vimos nos tópicos anteriores, há inúmeras razões para um indivíduo decidir imigrar, e existe, por outro lado, uma variedade de vínculos e relações que poderão se estabelecer, e que repercutem no formato e conteúdo de direitos dirigidos ao migrante. Para um debate sério e maduro, é importante considerar os interesses, agendas e preocupações de todos os membros das comunidades afetadas pela migração.

O debate que desejamos provocar tem como base a história evolutiva dos direitos humanos e dos instrumentos internacionais firmados visando à sua proteção,

90 Clóvis de Barros Filho e Júlio Pompeu, A filosofia explica as grandes questões da humanidade, p. 156.

91 De Plácido e Silva, Vocabulário jurídico, p. 328.

92 Isabel Estrada Carvalhais, A União Europeia e o outro - tensões e compromissos da lógica subjacente à sua gestão da imigração de países terceiros. Disponível em: <http://www.ces.uc.pt/ecadernos/media/ecadernos10/7\%\%20Isabel\%20Estrada\%20Carvalhais.pdf >. Acesso em: 27 set. 2013. 
confrontando-a a uma análise empírica obtida a partir da experiência da imigração na Europa, na América do Norte e na América Latina, pesquisa que empreendemos no capítulo seguinte.

É exatamente em função desses parâmetros que traçamos nosso ponto de partida para investigarmos a experiência das políticas migratórias dos países de maior fluxo de ingresso de estrangeiros motivados pela migração a trabalho, que será objeto de exame em capítulo específico, a seguir.

Carens, ao questionar o que é justo e injusto, certo ou errado, bom ou mau nas políticas públicas que objetivam regular a entrada de migrantes na Europa e nos Estados Unidos, destaca a prevalência do paradigma da soberania e da autodeterminação das nações para construir suas próprias leis e definir quem ingressará em seus respectivos territórios, colocando a questão de ética dessas decisões à luz dos direitos humanos, criticando a falta de mecanismos impositivos da eficácia dos direitos humanos nas políticas nacionais. ${ }^{93}$

Uma vez que delimitamos o tema à imigração para fins de trabalho, definimos os titulares de direitos, identificamos os direitos, traçamos os fios condutores, a saber, igualdade e ética, é oportuno traçarmos as bases sob as quais analisaremos as políticas migratórias trabalhistas no capítulo seguinte.

93 Joseph H. Carens, The ethics of immigration, p. 3-5. 


\section{Capítulo 2 \\ A EXPERIÊNCIA ESTRANGEIRA NAS POLÍTICAS DE MIGRAÇÃO}

Este capítulo analisa as políticas de imigração a trabalho, adotadas entre países que compõem os seguintes blocos econômicos regionais: União Europeia, Nafta e Mercosul, privilegiando uma amostragem dentre aqueles conhecidos como receptores de migrantes, em busca de contribuições aplicáveis à tipologia do trabalhador migrante sob o cenário brasileiro.

A importância deste estudo está diretamente relacionada à percepção das migrações como um tema estratégico nas relações internacionais do século XXI. Como ressalta Reis, o crescente número de migrantes em todas as partes do mundo é um fato incontornável e se coloca como um tema central, em constante debate nos fóruns internacionais.

De um modo geral, a União Europeia e o Nafta têm sido cobrados pela “discrepância entre discurso de direitos humanos desses blocos e países, e o tratamento que tem sido oferecido por eles aos imigrantes". ${ }^{94}$

É interessante notar que o Brasil participa desse debate, reivindicando um papel de liderança junto aos países sul-americanos, desempenhando uma função relevante na condenação da diretiva da União Europeia de junho de 2008, que objetivou impor e regular o retorno dos imigrantes, dentre os quais os latino-americanos, aos seus países de origem.

Na abertura do Terceiro Fórum Mundial da Aliança das Civilizações, realizado pela ONU no Rio de Janeiro em maio de 2010, o ex-Presidente Lula endureceu o discurso contra as políticas migratórias dos países ricos, acusando-os de serem incapazes de assumir os próprios erros e de impor sobre os países em desenvolvimento medidas protecionistas

94 Rossana Rocha Reis, A política do Brasil para as migrações internacionais, Contexto, Rio de Janeiro, v. 33, n. 1 jun. 2011. Disponível em: <http://www.Scielo.brlscielo.php:script+sci_arttex\&pid=S102$8529202011000100002 \&$ ing=en\&nrm=iso>. Acesso em: 5 out. 2013. 
que oneram bens e serviços exportados e responsabilizam os imigrantes pela crise social que enfrentam. $^{95}$

O desafio deste capítulo é, de um lado, não ceder aos discursos políticos e manter a isenção necessária para avaliar o ordenamento jurídico sob o qual circulam trabalhadores migrantes nacionais dos países-membros da União Europeia, do Nafta e do Mercosul e como circulam os nacionais de países terceiros, e, de outro lado, testar as normas de direito comunitário à luz da realidade, apreendendo pontos positivos e negativos, de modo a verificar como poderão inspirar a nova política migratória brasileira.

Se a retórica política brasileira favorável à proteção dos direitos humanos é verdadeira, a análise do direito comunitário dos países ricos deverá fornecer argumentos a favor da livre circulação de pessoas entre os países do Mercosul e obviamente propiciar o fluxo de nacionais de países terceiros, debate que desenvolveremos no Capítulo 4.

Evidentemente não intencionamos defender a transposição para o Brasil de institutos desenhados em contextos absolutamente distintos da realidade brasileira. Logo, um esclarecimento necessário se faz no sentido de que a investigação que empreendemos neste capítulo objetiva buscar inspeção para os lineamentos de uma política nacional compatibilizada com os padrões contemporâneos dos direitos humanos.

O objetivo é apresentar um mapa da gramática da migração sob a perspectiva dos direitos humanos, e para tanto seguimos um critério geoeconômico na medida em que as economias são as propulsoras da migração internacional.

\subsection{União Europeia}

A importância do estudo das migrações internacionais a trabalho da União Europeia é um reflexo do papel que a Europa desempenhou a partir do novo cenário observado após a Segunda Guerra mundial, com o avanço inegável do capitalismo e acentuação da divisão do mundo entre países pobres ricos.

95 Vitor Abdala, Lula diz que Brasil está aberto aos imigrantes. A Tarde, maio 2010. Disponível em: <http://www.atarde.com.brlpoliticalnoticia.jsf?id=2535914>. Acesso em: 28 maio 2010. 
Em relação aos migrantes ilegais, os recentes acontecimentos envolvem denúncias de tratamento desumano, sobretudo na Itália e na França.

Na Itália, o naufrágio junto à ilha de Lampedusa, ocorrido em outubro de 2013, e que acarretou a morte de centenas migrantes africanos e paquistaneses, reavivou o debate sobre a política europeia de migração. Cécile Kyenge Hashetu, ministra italiana para a integração ressaltou a necessidade de a agência europeia de controle de fronteiras (Frontex) adotar uma abordagem mais humanitária em relação aos migrantes, em vez da adoção de locais de detenção de migrantes, sem o mínimo de condições de higiene, alimentação e sem qualquer apoio para a regularização da permanência dos migrantes.

Eugênia Bonetti, uma freira italiana que presta serviços de apoio aos migrantes denuncia as condições miseráveis proporcionadas aos migrantes nesses espaços de confinamento. "Antigamente só ficavam 30 ou 60 dias e conseguiam suportar, ainda que nada tivessema para fazer. Agora chegam a permanecer 18 meses. É realmente insuportável, é tortura psicológica e a pessoa perde a sua humanidade". 96

A situação não é diferente na França, cujo número de migrantes ilegais provenientes da África, do Oriente Médio e da Romênia aumentou significativamente nos últimos anos. O governo francês vem sendo cobrado em relação à posição radical que vem adotando em relação aos migrantes ilegais.

Estima-se que em 2013, o governo francês expulsou mais de 21 mil migrantes ilegais que viviam no país, a maior parte de origem romena. Pelos dados oficiais, os romenos representaram $18 \%$ das expulsões. ${ }^{97}$

O tema é pauta das reuniões entre os chefes de Estado e de governo da UE. Itália, Malta e Grécia são os países mais afetados pelo novo fluxo migratório no Mediterrâneo.

\footnotetext{
${ }^{96}$ Disponível em < frontex-deve-ser-mais-humanitaria-com-migrantes-diz-ministra-italiana> Acesso em 12 nov. 2013.

${ }^{97}$ Disponível em: <http://agenciabrasil.ebc.com.br/noticia/2013-10-09/franca-deve-expulsar-mais-de-21-milimigrantes-ilegais-ate-fim-do-ano>. Acesso em: 12 dez. 2013.
} 
Dito isso, retomamos a proposta desse tópico, que se resume à análise da legislação supranacional em matéria de direito trabalhista voltado à migração a trabalho na União Europeia. A nosso ver, é justamente a ausência de uma política migratória humanista e não excludente que empurra as pessoas em busca de alternativas ilegais, que comumente envolvem a atuação criminosa de grupos organizados para explorá-los.

A União Europeia, conforme pontua Oscar Ermida Uriarte, é a única entidade que efetivamente recebeu a transferência da soberania de seus Estados-membros, que se aplicam mediante a existência das Diretivas sobre vários temas trabalhistas, principalmente a livre circulação de trabalhadores, e outros direitos, desde a transferência de estabelecimentos, a despedida coletiva, a insolvência patronal, o contrato por tempo determinado, além do descanso semanal, das férias, igualdade de tratamento, saúde e segurança, licença-paternidade, formação profissional, informação e consulta. ${ }^{98}$

Nessa perspectiva, objetivamos analisar as regras que regulam a admissão, o emprego e os direitos garantidos a esse contingente de trabalhadores (civis, políticos, econômicos, sociais, residência e direito de reunião familiar).

Para concluirmos qual é o estágio atual dos países estudados em relação aos direitos garantidos aos estrangeiros, valemo-nos dos critérios mais comumente utilizados na doutrina: a) sistema de quotas; b) restrições impostas pela demanda de trabalho; restrições impostas pela nacionalidade e outras características pessoais. ${ }^{99}$

As décadas de 50 e 60 marcaram um período significativo para a União Europeia, em virtude do crescente fluxo de trabalhadores estrangeiros atraídos pela expansão industrial e crescimento econômico que adentrou na década de 70. Segundo estimativas de K. Mayer, cerca de 8 milhões de estrangeiros se encontravam empregados

\footnotetext{
${ }^{98}$ Disponível em: <http://wilfredosanguineti.files.com/2011/derechos-laborales-y-comercio exterior>, p. 13. Acesso em: 27 set. 2013.

99 Martin Ruhs, The price of rights: regulating international labor migration, p. 59-65.
} 
na Europa ocidental, com predominância na Alemanha Ocidental, França, Reino Unido e Suíça. ${ }^{100}$

Mayer destaca uma característica muito interessante acerca da forma como esses migrantes eram percebidos pelos países europeus: como uma força extra para uma carência temporária de mão de obra que poderia beneficiar tanto os países de origem, pois a migração poderia reduzir o desemprego, quanto o país de destino, que preenchia funções de baixa qualificação, recusadas pelos nativos.

Contudo, o que era para ser provisório se tornou um fluxo permanente e crescente de trabalhadores para o estrangeiro. Estudos mais recentes, elaborados pelas Nações Unidas, em 2010, indicam a existência de 69.819.281 migrantes vivendo em diferentes países da União Europeia. ${ }^{101}$

A experiência europeia na regulação da livre circulação de pessoas é única no planeta, pois se resume em: renúncia parcial às competências nacionais, supranacionalismo e intergovernamentalismo e ascensão do elemento supranacional em todos os Estadosmembros, sendo considerado o modelo mais aperfeiçoado de integração regional. ${ }^{102}$

\subsubsection{Evolução}

O período de 1945 a 1959 é reconhecido como o início do processo de cooperação que resultou no que hoje conhecemos como a UE uma parceria econômica e política que congrega 27 países, que superou antigas rivalidades, com o objetivo de promover a cooperação regional, mediante a instituição do livre comércio entre os países, a livre circulação de pessoas e a manutenção da segurança e democracia, por meio de instituições supraestatais independentes.

O contexto político e social vivenciado na década de 50 estava centrado no crescimento econômico propiciado pelo momento Pós-Segunda Guerra, promovido pela

${ }^{100}$ K. Mayer, Intra-European migration during the past twenty years, p. 9.

101 United Nations, Departament of Economic and Social Affairs, Population Division. Trends in International Migration Stock. Disponível em: 〈http://esa.un.org \migration $\backslash p 2 k 0 d a t a . a s p>$. Acesso em: 21 set. 2012.

102 Cássio Mesquita Barros, Perspectivas do direito do trabalho no Mercosul, p. 82. 
vontade de crescimento, liberdade econômica e justiça social. Luís Marinho ressalta que os anos 50 representaram o renascimento do idealismo político social da democracia alemã de Weimar, que fora esmagado pela crise dos anos 30.

Foi a fase da refundação da Europa e um esforço para evitar que a desunião desembocasse em uma nova guerra no futuro. $\mathrm{O}$ acentuado pensamento liberal impulsionou o compartilhamento de objetivos comuns, voltados à paz, liberdade econômica e justiça social como valores fundantes da nova Europa. ${ }^{103}$

O primeiro passo desse renascimento se deu com a assinatura do Tratado CECA (Comunidade Europeia do Carvão e do Aço), em 1951, no fim da Segunda Guerra Mundial, congregando França, Alemanha, Itália e os países do Benelux, com o objetivo de produzir a livre circulação do carvão e do aço, sem direitos aduaneiros nem encargos, com a abolição de quaisquer práticas discriminatórias como subvenções, auxílios, encargos ou práticas restritivas. O Tratado CECA foi alterado pelo Tratado de Bruxelas, assinado em 1965, também designado de tratado de fusão, sobretudo porque criou um Conselho e uma Comissão e um orçamento de funcionamento único. O tratado entrou em vigor em 1951 e expirou em 2002. ${ }^{104}$

A década de 60 marcou a queda das barreiras alfandegárias entre os seis países que integravam a ainda chamada comunidade europeia. Com os Tratados de Roma, foi instituída a Comunidade Econômica Europeia (CEE) e a Comunidade Europeia da Energia Atômica (Euratom). Com a criação da união aduaneira, foram eliminados os direitos aduaneiros e foi instituído um sistema uniforme de tributos sobre as importações.

A moeda oficial, o Euro, todavia, só foi adotado em janeiro de 1999, e restrito a transações comerciais e financeiras. A partir de 2002, com a criação do mecanismo das taxas de câmbio, passou a ser utilizado como moeda comum aos cidadãos da UE. O Euro é adotado por 15 dos 27 países-membros da comunidade: Alemanha, Áustria, Bélgica,

103 Luís Marinho foi Vice-Presidente do Parlamento Europeu, atual presidente do Eurofacts e professor universitário em Portugal. As opiniões aqui reproduzidas foram extraídas do artigo Europa, a descoberta do paradigma, publicado no periódico do CIEDA e do CEIS20, em parceria com GPE e a RCE, n. 7, jul.dez. 2012, semestral. Disponível em: <http://www.europa-direct=aveiro.aeva.eu/debateeuropa/.> Acesso em: 17 fev. 2013.

104 Disponível em: <http://europa.eu/Legislation_summaries/institutional_affairs/treaties-esc_en.htm>. Acesso em: 17 mar. 2013. 
Eslovênia, Espanha, Finlândia, França, Grécia, Irlanda, Itália, Luxemburgo, Holanda, Portugal, Chipre e Malta. ${ }^{105}$

Dentre os instrumentos que se seguiram, merecem destaque o Ato Único Europeu (AUE), assinado em 1986, com objetivo de reformar os tratados anteriores, permitindo o fortalecimento do papel político do Parlamento Europeu e a ampliação das competências comunitárias. Na sequênciaeuropeia, o Tratado da União Europeia (TUE), o tratado de Maastricht assinado em 1992, com vigência a partir de 1993, estabeleceu a União Europeia, conferindo ao Parlamento uma maior participação na tomada de decisões.

Em 1993, a União Europeia atinge o status de cooperação máxima, com um mercado único, contemplando as quatro liberdades: movimento de produtos, serviços, pessoas e capital. Abriram-se, portanto, as portas ao Centro e ao Leste europeus, oferecendo a milhões de indivíduos uma nova cidadania. ${ }^{106}$

Em matéria de políticas de emprego, o Tratado de Amsterdã, assinado em 1997, estabeleceu uma política comunitária de emprego, mediante a cooperação entre certos Estados-membros. Para muitos, o Tratado de Amsterdã representa uma mudança de curso da UE, agora mais voltado à proximidade com os cidadãos do bloco. Roger Blaipain observa essa mudança no próprio texto do Tratado em que se lê: "an ever closer union among the peoples of Europe, where decisions are taken as closely as possible to the citizen" - uma união mais próxima entre os povos da Europa, no qual as decisões são tomadas o mais próximo possível dos cidadãos. Esse texto substituiu o anterior que se referia "Union with a federal goal" - união com uma meta federal. ${ }^{107}$

O tratado mais relevante foi, contudo, o Tratado de Lisboa, assinado em 2007, implantando amplas reformas. Substituiu a terminologia Comunidade Europeia, eliminando completamente a antiga arquitetura trazendo uma nova repartição das competências entre a UE e os Estados-membros.

\footnotetext{
105 Disponível em: <http://europa.eu/about-eu/countries/index_pt.htm>. Acesso em: 17 mar.2013.

106 Disponível em: <www.Ecb.int/ecb/legal/pdf/ce 32120061229pt00010331.pdf〉. Acesso em: $17 \mathrm{mar}$. 2013.

107 Roger Blainpain, The global workplace: international and comparative employment law: cases and materials, p. 276.
} 
O Tratado de Lisboa entrou em vigência em dezembro de 2009. Considerado um tratado reformador, é composto por estruturas jurídicas complexas: Tratado da União Europeia e Tratado da Comunidade Europeia requalificado como Tratado relativo ao Funcionamento da União Europeia (TFUE), portanto houve uma consolidação ou fusão dos três tratados, com a atribuição à União Europeia de personalidade jurídica própria. ${ }^{108}$

Com o Tratado de Lisboa, ocorreram sensíveis alterações na legislação comunitária da UE, de modo que muitas doutrinas ficaram datadas e não refletem a realidade desse bloco de integração regional.

\subsubsection{Instituições}

O Parlamento Europeu (PE) e o Conselho da União Europeia (Conselho) constituem as principais instituições da UE na esfera do Poder Legislativo. Compostos por deputados de cada Estado-membro, cujo número segue o Tratado de Lisboa: pelo menos 6 e no máximo 96 de cada Estado-membro, o PE é responsável pelo debate e aprovação da legislação da UE (com o Conselho), além da aprovação do orçamento da UE, e também fiscaliza as outras instituições, inclusive a Comissão, assegurando que funcionem de forma democrática. $^{109}$

$\mathrm{O}$ art. 223. ${ }^{\circ}$, inciso 1, da versão consolidada do Tratado da União Europeia, publicado em 30.03.2010, no Jornal Oficial da União Europeia, atribui ao Parlamento a adoção de regulamentos de iniciativa própria, e, de acordo com o processo legislativo da UE, o Parlamento compõe-se de 27 membros. ${ }^{110}$

Após o Tratado de Lisboa, foram criadas novas regras de votação para o conselho, agora por maioria qualificada, e além da extensão do procedimento de maioria qualificada para novas matérias.

108 Disponível em: <europa.eu/legislation_summaries/institucional-affairs/treaties/treaties_ecsc_pt.htm>. Acesso em: 3 mar. 2013.

109 Disponível em: <europa.eu/institutions-bodies/european-parliament/index_pt.htm>. Acesso em: 16 mar. 2013.

110 Disponível em: <eu-lex.europa.eu /LexUriServ /LexUriServ.do?uri=OJ:C:2010:083:004:0020:PT:PDF>. Acesso em: 17 mar. 2013. 
Outro aspecto novo trazido pelo Tratado de Lisboa foi a criação do grupo de reflexão para o Conselho europeu, denominado Euro grupo (art. 123 do TFUE).

A criação pelo Conselho europeu do "Grupo de Reflexão Independente", composto por 12 membros e presidido por Felipe Gonzáles, objetiva identificar, analisar e propor soluções para os desafios que se colocarão à UE até 2030.

O grupo apresentou seu primeiro relatório em Bruxelas, em 14.12.2007, enfatizando a necessidade de transformar a Europa em destino atrativo para os migrantes qualificados, de modo a enfrentar o desafio demográfico causado pelo envelhecimento da população.

De acordo com o relatório, a Europa continua com uma elevadíssima expectativa de vida e baixíssima taxa de natalidade. Estima-se que na maior parte dos Estados-membros a expectativa de vida está próxima dos 75 anos para homens e 82 para as mulheres, e deverá aumentar para mais 15 ou 20 anos no decorrer do século XXI. Enquanto isso, a média de filhos continuará em torno de 1,5 por mulher. Se não forem propostas políticas compensatórias entre os contribuintes e os pensionistas, os próximos 40 anos não serão nada promissores para a Europa, para os quais se prevê que serão necessários quatro trabalhadores contribuintes para cada três aposentados. ${ }^{111}$

A migração internacional é, portanto, uma necessidade a se pôr em prática para a Europa. Estima-se que serão necessários cerca de 100 milhões de novos trabalhadores, entre nacionais e estrangeiros, para acomodar esse déficit de contribuintes, tornando evidente a necessidade de uma abordagem mais receptiva à questão da imigração.

Todavia, para o Vice- Presidente Franco Fattini, responsável pela comissão de justiça, liberdade e segurança do Conselho, a Europa vê a migração como um encargo a suportar, quando a realidade mostra que é sem dúvida uma oportunidade a aproveitar. ${ }^{112}$

111 Projeto Europa 2030. União Europeia. Luxemburgo, Serviço das Publicações da União Europeia. 2010 ISBN 978-92-824-2711-8. Disponível em: <www.Consilium.europa.eu /uedocs /cms_data /librairie /PDF /QC3210249PTC.pdf>, p. 25. Acesso em: 17 mar. 2013.

112 Disponível em: <www.Eu-um.europa.eu/articles/en/article_6609_en.htm>. Acesso em: 16 mar. 2013. 
Evidentemente que a Europa, assim como todos os países que necessitam de migrantes, objetiva atrair profissionais qualificados, mediante a criação de sistemas de pontos ou de avaliações.

É necessário desenvolver políticas de acesso comuns entre os Estadosmembros e eliminar incoerências em relação aos estrangeiros em situação irregular, provendo-lhes a emissão de vistos, de modo que tanto possam usufruir dos benefícios sociais quanto contribuir para a sustentabilidade econômica e social da Europa. A migração constitui um ponto crucial para o desenvolvimento da UE e reconhece a necessidade de coordenar os fluxos migratórios de forma mais efetiva, integrando os cidadãos, protegendo-os de modo a assegurar os direitos fundamentais.

Em recente artigo disponibilizado à Comissão de Justiça, Frattini destacou os programas de ajuda financeira para 2007 a 2013, mediante os quais foram alocados aproximadamente 4 bilhões de euros para as questões migratórias. Desse fundo, 300 milhões de Euros foram destinados em 2007 para assistir à comissão e os Estadosmembros para o combate da migração ilegal, o desenvolvimento do diálogo entre países terceiros, estudo das causas da imigração e mecanismos de proteção dos direitos fundamentais dos migrantes.

Quanto aos refugiados, está previsto um fundo de 700 milhões de Euros para dar suporte aos Estados-membros na recepção de refugiados, provendo condições de concessão de asilo. Algo em torno de 300.000 pessoas se candidatam, por ano, para pedidos de asilo ou proteção similar em cada um dos países-membros.

Cabe à Comissão Europeia, de acordo com o art. $248 .^{\circ}$ do Tratado consolidado da União Europeia, o papel de elaborar propostas de legislação que serão apresentadas ao Parlamento e ao Conselho e gerir a aplicação das políticas e dos tratados. A Comissão é a instituição responsável por assegurar que a legislação da UE será aplicada em todos os Estados-membros.

A Comissão é composta por 27 membros, nomeados pelos respectivos Estadosmembros. O art. 213. ${ }^{\circ}$ do Tratado da Comunidade Europeia (EC Treaty) atualmente estipula que a Comissão é composta por pelo menos um cidadão de cada um dos Estados- 
membros, mas não deve incluir mais do que dois cidadãos de cada Estado. Os membros não devem seguir instruções de nenhum governo ou outros órgãos, de modo a garantir que a comissão tenha o direito de propor quaisquer temas para a legislação europeia. ${ }^{113}$

A Corte de Justiça, também denominada de Tribunal de Justiça da UE, com sede em Luxemburgo, é composta de três jurisdições: o Tribunal de Justiça, o Tribunal Geral, criado em 1988, e o Tribunal da Função Pública, criado em 2004. Tem o papel de garantir o respeito ao direito na interpretação e aplicação dos tratados. Fiscaliza a legalidade dos atos das instituições da UE, assegura o respeito, pelos Estados-membros, das obrigações decorrentes dos Tratados. E interpreta o direito em relação à UE quando instada por juízes nacionais. Desde que foram criadas, as três jurisdições proferiram cerca de 15.000 acórdãos. $^{114}$

Segundo o relatório de atividades 2011, a Corte tem sido instada a decidir sobre questões envolvendo a cidadania europeia e os direitos que são conferidos a um nacional de um Estado terceiro.

No processo envolvendo Ruiz Zambrano (acórdão proferido em 08.03.2011, C34/09) o Tribunal de Justiça se pronunciou sobre o direito de permanência e de trabalho de um cidadão de Estado terceiro que possui filhos nascidos no Estado-membro, os quais possuem nacionalidade do respectivo Estado-membro.

A Corte de Justiça entendeu que o art. 20. ${ }^{\circ}$ do TFUE veda que um Estadomembro recuse um nacional de Estado terceiro, que tem a seu cargo os seus filhos de tenra idade, cidadãos da União, à permanência no Estado-membro da residência destes últimos, do qual tem nacionalidade, e, por outro, recuse ao dito nacional de Estado terceiro uma autorização de trabalho, na medida em que essas decisões privam os referidos filhos do gozo efetivo e essencial dos direitos associados ao estatuto de cidadão da União.

Assim, se não for atribuída uma autorização de trabalho, essa pessoa corre o risco de não dispor dos recursos necessários para sustentar a si própria e a sua família, com

113 Disponível em: <http: //www.ec.europa.eu/ey_law/introduction/>. Acesso em: 17 mar. 2013.

114 Disponível em: <http://www.curia.europa.eu/jcms/upload/docs/application/pdf/2012-06/ra2011_ active_cour_pt_pdf>. Acesso em: 17 mar. 2013. 
a consequência de se ver obrigada a deixar o território do país com seus filhos, cidadãos na União, que seriam privados dos direitos conferidos pelo estatuto de cidadão da União.

O direito comunitário da UE é organizado por fontes primárias e secundárias, conforme as disposições da Seção 1, arts. 288..$^{\circ}$ a 299. ${ }^{\circ}$, do Tratado consolidado da União Europeia. As fontes primárias consistem basicamente das disposições contidas nos Tratados e protocolos. ${ }^{115}$

A fonte secundária do direito comunitário encontra-se nas decisões proferidas pela instituições europeias, conforme acima exposto. Também coexistem normas de direito instituídas internamente pelos países-membros, além de relações contratuais firmadas entre países.

As fontes de direito secundárias são promulgadas pelo Conselho e pela Comissão Europeia. Segundo Roger Blainpain, essas duas instituições têm competência para adotar cinco distintos tipos de medidas. ${ }^{116}$

Três delas têm força obrigatória, denominadas de regulamentos, diretivas e decisões. Apenas as duas outras, denominadas de recomendações e opiniões, não possuem força normativa sobre os Estados-membros.

\subsubsection{Regulamentos, decisões, diretivas, recomendações e pareceres}

Regulamentos e decisões são essencialmente decisões tomadas, conjunta ou separadamente, pelo Conselho e a Comissão Europeia. De acordo com o art. 288. ${ }^{\circ}$ (e-art. $249 .^{\circ}$ ) na versão consolidada do Tratado da UE, publicado em 30.03.2010. ${ }^{117}$

Todos os regulamentos possuem caráter geral e, uma vez promulgados, se aplicam de forma vinculativa sobre todos os Estados-membros, sem a necessidade de

115 Disponível em: <eu-lex.europa.eu /LexUri Servi /LexUriServ.do?uri=OJ:C:2010:083:004:0020: PT:PDF>. Acesso em: 17 fev. 2013.

116 Roger Blainpain, The global workplace: international and comparative employment law: cases and materials, p. 280.

117 Disponível em: <eu-lex-europa/JOHtml.do?uri=OJ:C:2010:083:SOM:EM:HTM>. Acesso em: 17 mar. 2013. 
nenhuma lei interna que os aprove. As decisões, contudo, podem ser designadas a um ou mais Estados-membros, e nesse caso a força normativa só é obrigatória para estes, conforme expressamente dispõe o art. 288 acima mencionado. As Recomendações e os Pareceres não possuem força vinculativa.

As diretivas vinculam cada Estado-membro destinatário, deixando, no entanto, às instâncias nacionais a competência quanto à decisão sobre a forma e os meios para o efetivo cumprimento. $\mathrm{O}$ art. 288 do Tratado acima mencionado permite concluir que a diretiva é bem mais flexível que os regulamentos, porquanto permite às autoridades nacionais maior liberdade para adaptar o texto e as determinações ao direito interno.

Os resultados, portanto, contam mais do que a forma como a diretiva será implantada no respectivo país, inclusive se o cumprimento se dará mediante uma lei ou outros meios. Nesse particular, Roger Blanpain destaca a experiência de alguns Estadosmembros em que as diretivas são objeto de acordos coletivos nos quais mais de um Estadomembro adere. Isso é permitido em países como a Bélgica, França, Alemanha e Holanda. ${ }^{118}$

Blanpain exemplifica como ocorreu na Bélgica, quanto a Diretiva n. 77, de 14.02.1997, que trata da transferência de empresas, que foi submetida a uma regulamentação coletiva negociada pelo Conselho Nacional do Trabalho em 1985 e estendida sua aplicabilidade à Bélgica, por meio de Decreto Real, passando a ter força vinculativa para todos os empregadores e seus empregados com força normativa, inclusive por meio de leis criminais.

Outro exemplo é a normativa sobre os conselhos de empresa (uma versão das comissões de fábrica no Brasil), de 22.09.1994. O autor elucida que o teor da normativa foi parcialmente transposta para as leis nacionais da Bélgica e da Noruega por meio de acordos coletivos.

118 Roger Blainpain, The global workplace: international and comparative employment law: cases and materials, p. 281. 
Evidentemente, essa forma de adequação das diretivas não é isenta de discussões e caberá à Comissão Europeia avaliar no devido tempo se o mecanismo utilizado alcançou a finalidade da direita.

A Corte Europeia igualmente poderá ser instada a se manifestar e poderá declarar que os Estados não cumpriram a diretiva, o que poderá acarretar a imposição de penalidades pelo descumprimento.

A Diretiva n. 2.204/114/EC estabelece regras comuns para a admissão de não europeus aos Estados-membros para o propósito de estudos, "pupil Exchange", treinamento sem remuneração e serviços voluntários.

A Diretiva n. 2.005/71/EC estabelece procedimentos específicos para a admissão de nacionais de países terceiros por mais de três meses para o propósito de pesquisa científica.

A Diretiva n. 2.011/98 do Parlamento Europeu e do Conselho foi publicada em 13.12.2011, e objetiva aplicar um único procedimento para a concessão de vistos de ingresso para nacionais de Estados terceiros, que não são membros da UE, de modo a harmonizar direitos de residência e trabalho no território de cada um dos 27 paísesmembros, além de um conjunto de direitos mínimos assegurados aos trabalhadores regulares.

Uma Diretiva que gerou enorme polêmica, inclusive por parte do governo brasileiro, é a Diretiva 2008/115, do Parlamento Europeu, chamada de "Diretiva de Retorno", mediante a qual o Parlamento Europeu aprovou a política migratória europeia voltada a promover o regresso voluntário de imigrantes ilegais, além de estabelecer normas no que dizem respeito ao período de detenção e à interdição de entrada na UE. ${ }^{119}$

119 Disponível em: 〈http://www. Europarl.europa.eulsides/getDoc.do:pubRef=-l\>. Acesso em: 6 out. 2013. 


\subsubsection{Circulação de pessoas}

A livre circulação de pessoas entre os países-membros e sobretudo de trabalhadores é um dos princípios básicos da UE. O art. 3. ${ }^{\circ}$ do Tratado da UE estabeleceu um mercado interno caracterizado pela eliminação de quaisquer barreiras à livre circulação de produtos, pessoas, serviços e capital. A liberdade do indivíduo de transpor as fronteiras do país de origem para qualquer país da UE é um direito fundamental do cidadão e de sua família. $^{120}$

O cidadão de um dos 27 países da UE é automaticamente cidadão da UE. A cidadania da UE complementa a cidadania nacional e confere aos cidadãos direitos importantes, consagrados na Carta dos Direitos Fundamentais da UE e no Tratado sobre o funcionamento da UE.

O art. 21 da Carta dos Direitos Fundamentais da UE proíbe a discriminação em razão da língua e do fato de pertencer a uma minoria nacional, e o inciso 2 do art. 21 é enfático quanto à proibição de toda discriminação em razão da nacionalidade.

$\mathrm{Na}$ versão consolidada do Tratado sobre o funcionamento da UE, o tema é tratado no Título IV, cujo Capítulo 1 é dedicado à livre circulação de trabalhadores, que é assegurada pelo art. 45 (ex-art. 39 do TCE).

Em linhas gerais, o tratado assegura, com exceção dos empregados da administração pública, a livre circulação dos trabalhadores mediante a abolição total de qualquer discriminação em razão da nacionalidade, mas manteve certas limitações justificadas com base nas políticas de segurança e saúde públicas. Nessas bases, o indivíduo é livre para:

i. Responder a ofertas de trabalho que lhe forem feitas;

ii. Deslocar-se livremente no território dos países-membros com essa finalidade;

120 Disponível em: <http://www.europarl.europa.eu /charter /pdf /text_pt.pdf>. Acesso em: 17 mar. 2013. 
iii. Residir em um dos Estados-membros com o propósito de trabalho, mas em conformidade com as disposições legislativas, regulamentares e administrativas que regem o emprego dos trabalhadores nacionais;

iv. Permanecer no território do país-membro depois de ter sido empregado no respectivo Estado, mas igualmente sujeito a condições que serão objeto de regulamentos estabelecidos pela Comissão Europeia.

Quanto à seguridade social, o art. 48 (ex-art. 42 do TCE) dispõe que o Parlamento e o Conselho deliberarão sobre medidas necessárias ao estabelecimento de um sistema de segurança social que assegure aos migrantes, assalariados e não assalariados, e inclusive às pessoas que deles dependam:

i. A totalização de todos os períodos tomados em consideração pelas diversas legislações nacionais, tanto para fins de aquisição e manutenção do direito às prestações como para o cálculo destas.

ii. O pagamento das prestações aos residentes nos territórios dos Estadosmembros.

\subsubsection{Espaço Schengen}

Em 14.06.1985, foi assinado em Schengen, Luxemburgo, um acordo relativo à supressão gradual dos controles fronteiriços comuns entre a França, Alemanha, Bélgica e Países Baixos, denominado "Espaço Schengen" de livre circulação de pessoas, independentemente de sua nacionalidade. Gradualmente, outros países aderiram, dentre os quais se destacam a Alemanha, Itália, Espanha, Portugal, Grécia, Áustria, Dinamarca, Finlândia, Suécia, Noruega, Islândia, entre outros, somando atualmente o número de 25 países. O Reino Unido e a Irlanda aderiram parcialmente, conservando o direito de controlar as pessoas em suas fronteiras, mas cooperando o sistema de informação Schengen em matéria de prevenção a tráfico de substâncias entorpecentes. ${ }^{121}$

121 Disponível em: <http://europa:eu /legislationᄀ_summaries /justice ᄀ_freedom_security /free_moviment_of_persons_asylum_immigration /133020_htm>. Acesso em: 17 mar. 2013. 
O controle das fronteiras no espaço Schengen consiste basicamente na supressão de controles das fronteiras internas, garantindo a harmonização dos controles nas fronteiras externas ao espaço.

Há uma harmonização das condições de entrada e de vistos para estadias de até três meses, de modo que qualquer visto emitido por um Estado-membro dos acordos de Schengen, ou até mesmo a ausência de requerimento de vistos, a exemplo dos nacionais do Brasil, se aplica para todo o território Schengen.

Todo cidadão de um país terceiro que circule de um Estado-membro para outro do território Schengen é obrigado a fazer uma declaração às autoridades. Foi implantada uma coordenação entre administrações nacionais para vigiar as fronteiras e para o reforço da cooperação jurídica e a criação de um sistema de informações Schengen (SIS) objetivando coibir o tráfico de entorpecentes e colaborar em assuntos criminais.

Cristiane M. S. Lopes destaca três aspectos relevantes do espaço Schengen: a) a importância do sistema SIS, como uma medida de cooperação eficaz na extradição e execução de sentenças penais; b) a incorporação das regras relativas ao espaço Schengen à UE por meio do Tratado de Amsterdã, em 1997; e c) as diretivas da UE que compõem um quadro mínimo de garantias aos cidadãos extracomunitários, a saber: A diretiva 2003/109, sobre o estatuto dos nacionais de países terceiros residentes de longa duração e a Diretiva 2004/114 sobre os requisitos de admissão dos nacionais de países terceiros para fins de estudo, atividades não remuneradas, intercâmbios e trabalhos voluntários. ${ }^{122}$

\subsubsection{A cidadania europeia como fator de igualdade}

O ano de 2013 foi eleito como o ano europeu da cidadania, dedicado ao estudo e debates sobre os direitos e as vantagens práticas da cidadania na UE. Portanto, há um reconhecimento de que, mesmo com o atingimento de um mercado único, sem barreiras para o livre trânsito de bens, serviços, capital e pessoas, o cidadão europeu leva vantagem

122 Cristiane Maria Sbalqueiro Lopes, Direito de imigração: o Estatuto do Estrangeiro em uma perspectiva de direitos humanos, p. 349. 
sobre outras cidadanias. Assim, nada mais atual do que analisar em que medida é assegurada a livre circulação de pessoas e de trabalhadores da UE. ${ }^{123}$

A versão consolidada do Tratado da União Europeia, publicado em 30.03.2010, no Official Journal of European Union, destaca o novo estágio de progresso da integração entre os países da União Europeia, enfatizando os quatro objetivos: o primeiro e mais significativo para nosso estudo se resume à promoção da economia, o progresso social, aumentar os postos de trabalho, mediante a facilitação da liberdade de locomoção de pessoas para além das fronteiras dos países-membros. O segundo é um sistema comum de segurança das fronteiras. O terceiro é a intensificação da proteção aos direitos e interesses dos nacionais dos Estados-membros, com a introdução da cidadania da União. O quarto é o desenvolvimento de uma cooperação muito próxima nas questões judiciais e de segurança interna. $^{124}$

\subsubsection{Empregabilidade}

Em janeiro de 2013, segundo os dados da Eurostat, órgão oficial de estatísticas da União Europeia, 18.998 milhões de cidadãos na zona do Euro, que inclui os países que adotaram o Euro como moeda, estavam desempregados, representando um acréscimo do nível de desemprego de 1.909.000 desempregados em comparação com o mês de janeiro de 2012.

A maiores taxas de desemprego foram observadas na Grécia (20,8\%), Chipre $(14,7 \%)$, Portugal $(17,6 \%)$ e Espanha $(26,2 \%) .{ }^{125}$ Esses dados refletem evidentemente a recessão econômica, que economistas atribuem aos impactos fiscais acarretados pela adoção de uma moeda comum em países com estruturas tão distintas, a exemplo de Simon Wren-Lewis, que defende a ideia de que a atual recessão não se deve a governos perdulários, tal como defendido pelas elites dominantes, pois, se assim fosse, a crise de

123 Disponível em: <http:/ / Europa.eu/eu-history/index_pt.htm>. Acesso em: 10 maio 2013.

124 Disponível em: <http:// Eur-lex.europa.eu/LexUriServ.do?uri=OJ:C:2010:083:0013:0046:em:PDF>. Acesso em: 16 mar. 2013.

125 Disponível em: <http:// epp.eurostat.ec.europa.eu/statistics_explained/index. php/Unemployment_statistics>. Acesso em: 16 mar. 2013. 
2010 teria se encerrado com as medidas austeras de corte de gastos e aumento de impostos, o que não aconteceu. ${ }^{126}$

Para Simon Wrend-Lewis, as medidas de austeridade estagnaram a economia e impediram qualquer recuperação, portanto há fortes evidências de que os princípios da macroeconomia estão se refletindo nas estatísticas da crise econômica da zona do Euro.

\subsubsection{Desafios}

As políticas migratórias, tal como divulgadas pela Comissão Europeia, estão fundamentadas nos seguintes princípios: prosperidade, a significar que a migração legal pode contribuir com o desenvolvimento socioeconômico da União Europeia; solidariedade, os países europeus devem compartilhar recursos de modo a auxiliar os países de origem e de trânsito dos migrantes; segurança, não há nenhum pudor em afirmar que cada país deve incrementar sua legislação de modo a abordar inclusive a imigração ilegal.

Segundo o relatório de Nadja Hirsch, representante alemã da Aliança dos Liberais e Democratas para a Europa, o maior desafio para o sistema de migração da UE é atrair os estrangeiros qualificados e facilitar a sua integração, mediante um sistema de seguridade social para pessoas voltado a assegurar que os aportes realizados em um país possam ser computados para os efeitos da pensão para a aposentadoria. Esse sistema existe entre os países da UE, mas ainda não abrange indivíduos de países terceiros. ${ }^{127}$

Nadja destaca que os próximos dez anos serão decisivos para o desenvolvimento da UE, os Estados-membros necessitam compensar a maior taxa de envelhecimento dos países, com a facilitação do ingresso de estrangeiros qualificados.

Ressalvando que existem países-membros sobre os quais a UE não é competente para impor a legislação comunitária, Gunther Marvers destaca, ainda, alguns

126 Professor de economia da Oxford University, cujos comentários foram publicados em 01.03.2013, em seu blog <Mainlymacro.blogspot.pt/2013/where-austerity-rules.htm?>. Acesso em: 16 mar. 2013.

127 Disponível em: <www.Europarl.europa.eu/news/en/hedlines/migration-we-need-a-point-systme-toattract-the-best-and-the brightest>. Acesso em: 16 mar. 2013. 
dos países, a exemplo da Inglaterra e da Dinamarca, que optaram por aplicar apenas o direito interno.

Além disso, existem áreas cinzentas em que não há plena certeza sobre a aplicação das fontes de direito europeias ou nacionais. Isso se deve ao fato de que apenas os tratados da UE e as Regulações da UE se aplicam imediatamente aos países-membros, enquanto as diretivas necessitam ser transpostas à lei nacional para sua plena eficácia de acordo com o corpo de regras instituídas pelas próprias diretivas da UE. ${ }^{128}$

Não obstante o direito assegurado ao direito de trabalhar e viver em quaisquer dos países-membros sem ser discriminado com base em critérios de nacionalidade, em temas como o acesso ao emprego, a remuneração e outras condições de trabalho, na prática, a mobilidade dos europeus entre cada um dos Estados-membros ainda enfrenta diversos obstáculos. Pesquisa divulgada pelo Eurobarometer, realizada em 2011, demonstrava que apenas $3,1 \%$ dos cidadãos europeus com idade entre 15 a 64 vivem em país distinto daquele em que nasceram. ${ }^{129}$

A pesquisa indica que $25 \%$ dos cidadãos europeus nunca consideraram viver e trabalhar em outro país-membro em virtude dos muitos obstáculos, tais como:

- aplicação de padrões de seleção diferentes aos estrangeiros daqueles destinados aos nacionais;

- aplicação de critérios de nacionalidade para o acesso de certas vagas de emprego;

- existência de quotas para nacionais em alguns setores (exemplo atletas profissionais);

28 Professor Gunter Marvher é especialista em direito imigratório na Alemanha e as suas considerações foram apresentadas e vertidas em artigo, durante a 5. ${ }^{\text {a }}$ Global Immigration Conference, presented by the IBA Immigration and Nationality Law Committee and supported by the International Bar Association IBA - nos dias 12-21de setembro de 2011, em Londres, Inglaterra, da qual participamos.

129 Disponível em: <http: / /europa.eu /rapid /press-releaseᄀ_AGENDA-13-11_en.htm>. Acesso em: 1. ${ }^{\circ}$ abr. 2013. 
- padrões diferenciados de condições de trabalho (remuneração, projeção de carreira, níveis etc.);

- dificuldades de acesso a benefícios sociais, cujas regras são muito mais favoráveis aos cidadãos locais;

- dificuldade no reconhecimento da experiência profissional e das qualificações adquiridas em outro país.

Na prática, há um crescente de denúncias no sentido de que a UE se fechou à migração dos nascidos fora dos Estados-membros, e é importante destacar que a liberdade de livre circulação a trabalho não é ilimitada nem mesmo em relação ao cidadão europeu. $^{130}$

De todo o exposto, concluímos que os cidadãos europeus possuem o direito fundamental de livre circulação, inclusive com o propósito de trabalhar em qualquer dos 27 Estados-membros.

Contudo, a análise do cenário fático descortinado em notícias recentes publicadas na imprensa revela que há uma barreira invisível, sobretudo nos países mais ricos, que reduz o uso desse direito fundamental para 2,5\% do número total da população dos países-membros da UE que vive e trabalha em outros países da UE.

Expostas as principais características da União Europeia em relação aos programas de migração a trabalho, selecionamos os quatro países que, segundo a Organização Internacional de Imigração, concentram populações mais numerosas de nascidos no estrangeiro: França, Alemanha, Espanha e Reino Unido. ${ }^{131}$

Em auxílio à análise, utilizaremos o Índice Mipex, que mapeia desde 2007 as políticas de integração entre todos os países da União Europeia, além da Noruega, Suíça, Canadá e Estados Unidos, Austrália, Japão e Sérvia.

\footnotetext{
130 Roger Blanpain, The global workplace: international and comparative law: cases and materials, p. 289.

131 Disponível em: <http://www.Iom.intlcmslenlsitesliomlstatistics.htm>. Acesso em: 5 mar. 2013.
} 
O indicador é aplicado a 34 países e oferece uma visão sobre o nível de integração entre as políticas migratórias em diferentes ambientes. Trata-se de um indicador desenvolvido pelo Conselho britânico e pelo grupo de políticas de migração, com o objetivo de dar visibilidade ao público e contribuir e estimular o desenvolvimento de novos padrões internacionais nas políticas migratórias e promover a integração social. ${ }^{132}$

O índice varia de 0 a 100 em seis distintos níveis:

i. 0: aos países cujos resultados se revelam criticamente desfavoráveis à migração;

ii. 1-20: resultados desfavoráveis;

iii. 21-40: resultados medianamente desfavoráveis;

iv. 41-59: resultados levemente favoráveis;

v. 60-79: resultados medianamente favoráveis;

vi. 80-100: resultados favoráveis.

O Índice Mipex analisa sete áreas-chave para que o estrangeiro de um terceiro país adquira o direito de residir legalmente no país de destino: 1. Medidas voltadas a coibir a discriminação; 2. Acesso à nacionalidade; 3. Acesso à permanência definitiva; 4. Políticas voltadas à participação política do migrante; 5. Migração a trabalho; 6. Reunião familiar; e 7. Acesso à educação.

Com base nesses sete indicadores, o Índice Mipex mapeia as políticas nacionais em comparação com a igualdade de direitos e as responsabilidades impostas aos migrantes e os equipara com outros países. Monitora como as políticas estão sendo alteradas ao longo do tempo, se estão piores ou melhores, e antecipa propostas de novas leis em andamento.

132 Disponível em: <http://www.mipex.eu>. Acesso em: 22 set. 2013. 


\subsubsection{Reino Unido}

Índice Mipex: 57 (levemente favorável)

O Reino Unido é um Estado soberano, que inclui a Grã-Bretanha, a Irlanda e outras pequenas ilhas. A população é estimada em cerca de 60.587 .000 habitantes e o produto interno bruto em 2010 alcançou US\$ 2.226 trilhões. O sistema de leis é composto por quatro fontes principais: lei, o sistema common law, as diretivas da União Europeia e a Convenção Europeia sobre os Direitos Humanos. O Parlamento do Reino Unido consiste na House of Commons e House of Lords, constituindo o mais relevante corpo legislativo.

O sistema Common Law é seguido na Inglaterra e em Wales, e basicamente representa que as decisões proferidas pelas Senior Appelate Courts se tornam parte da lei. O Reino Unido é membro da União Europeia, e o sistema de leis da UE se sobrepõe ao sistema de leis do Reino Unido.

O migrante encontrará no Reino Unido um sistema de direito público e privado. O direito civil se aplica a áreas como contratos e quebra de contratos, assuntos de família, e questões envolvendo direito à propriedade. A lei penal define os limites das condutas aceitáveis e pertence ao direito público. ${ }^{133}$

Quanto ao ingresso no país, todos os indivíduos que intencionam nele permanecer por mais de seis meses necessitam obter um visto, exceto os cidadãos da UE.

O Reino Unido é um dos países que explicitamente adota o sistema baseado na qualificação profissional para os cidadãos de países terceiros. Martin Ruhs aponta que os canais para a imigração de cidadãos de países terceiros é extremamente limitada e somente aberta aos altamente qualificados. ${ }^{134}$

O Reino Unido claramente prestigia a imigração de indivíduos muito qualificados mediante aplicação de um sistema de concessão de vistos de trabalho

133 Poorvi Chothani, Global mobility. An overview for Human Resource Professionals, p. 264.

134 Martin Ruhs, The price of rights: regulating international labor migration, p. 92-93. 
fundamentado em pontos. Com base nesse sistema, vistos são classificados a partir do TIER 1 ao TIER 5, dentre os quais se destacam:

O visto "TIER 1" aplica-se exclusivamente para pessoas reconhecidas internacionalmente como altamente qualificadas em áreas como ciência e artes e que desejam trabalhar no Reino Unido. Qualquer indivíduo qualificado para o "TIER 1" terá ampla liberdade para prestar serviços como empregado ou como autônomo para qualquer empresa ou pessoa e em qualquer lugar do território. O TIER 1 compreende ainda o visto como investidor, mediante a comprovação de capacidade de investimento equivalente a 1.000.000 libras no Reino Unido. ${ }^{135}$

O visto TIER 2 é destinado aos trabalhadores qualificados provenientes de países terceiros, somente aos estrangeiros que obtiverem uma proposta de emprego oferecida por uma empresa sediada no Reino Unido e paralelamente comprovem o cumprimento de certos requisitos. O visto também é aplicado para transferência entre empresas integrantes dos grupos econômicos multinacionais.

O visto denominado "General" é destinado a pessoal exclusivamente para ocupações em que o governo identificou que não há interesse por parte dos nacionais. Tais cargos são divulgados por uma lista oficial, acessível pelos empregadores locais interessados em patrocinar a estada de um estrangeiro, mediante o pagamento de um salário não inferior a 150.000 libras anuais. O número de vistos disponíveis para essa categoria de migrantes é estipulada por um sistema de quotas. No período de 2011 a 2012 o número de vistos disponíveis foi de 20.700 .

Segundo os indicadores do Mipex, a seguir apresentados, a visão geral sobre a receptividade ao migrante internacional está sendo reconstruída, após o debate de 2004 sobre custos e benefícios da migração internacional, inclusive de nacionais dos paísesmembros da UE. ${ }^{136}$

Todavia, o governo passa por forte oposição e pressão de grupos para limitação à migração sob o visto "general". A obtenção da cidadania é um processo extremamente

135 Russel Brimelow, Global Mobility Handbook 2010, p. 166.

136 Disponível em: 〈http://www. Mipex.euluk>. Acesso em: 22 set. 2013. 
burocrático, baseado na avaliação sobre a contribuição que o estrangeiro poderá trazer à comunidade, recebendo a pontuação 9 no indicador Mipex.

Em relação à migração para o trabalho, para os cidadãos não pertencentes à UE altamente qualificados pelo sistema de pontos, o cenário apresenta-se favorável apenas após a aprovação nesse sistema. Segundo dados do Mipex, os migrantes são em geral tratados de forma idêntica aos trabalhadores britânicos. O Reino Unido não limita ou restringe o acesso a qualquer posto de trabalho ou região a essa categoria de migrantes. Todavia, há uma restrição de acesso aos benefícios da previdência social, como ocorre na maior parte dos países receptores de migrantes, tais como França, Estados Unidos, Dinamarca, Espanha, entre outros.

Na área de reunião familiar, desde 2008 a idade do candidato ao ingresso no país foi limitada a 21 anos, recebendo a pontuação 2 no indicador Mipex.

As leis antidiscriminação passaram por uma modernização em 2010, mediante o Equality Act 2010, com o objetivo de estender a proibição da discriminação em razão da raça, opção religiosa e aprimorar medidas de eficácia contra atos discriminatórios. ${ }^{137}$

\subsubsection{França}

Índice Mipex: 51 (levemente favorável) ${ }^{138}$

A França é dividida em 22 regiões e 6 distritos administrativos Départements, além de distritos e territórios no exterior. As relações de trabalho são preponderantemente reguladas pelo Código de Trabalho, regulações administrativas e jurisprudência. Instrumentos coletivos são aplicáveis por setor de atividade e muitos se destinam aos empregados de uma empresa ou a um determinado grupo. ${ }^{139}$

O sistema jurídico francês é baseado na lei civil e é codificado em múltiplos códigos. Para os propósitos de análise da política migratória, interessa o Código de Entrada

\footnotetext{
137 Disponível em: <http:I|www.equalities.gov.uklequality_act_2010,aspx>. Acesso em: 22 set. 2013.

138 Disponível em: <http://mipex.eu/france>. Acesso em: 23 set. 2013.

139 Nixon Peabody, Global Mobility, p. 118-123, e Karl Waheed, Global Mobility, Poorvi Chotani, p. 77.
} 
e Estada de Estrangeiros e o Direito dos Refugiados (Ceseda), que dispõe sobre os direitos ao visto de trabalho, vistos pessoais e familiares, além dos vistos humanitários. As Diretivas da UE, além de regulações e jurisprudência, são aplicáveis à França, na qualidade de Estado-membro.

Os vistos para ingresso e permanência de estrangeiros no país são expedidos pelo Ministro de Assuntos Estrangeiros "Ministére de Affaires Etrangéres", por meio dos consulados no exterior. O cumprimento das normas é fiscalizado pela Polícia de Fronteiras (PAF).

Os vistos de trabalho são de competência da administração do trabalho regional Direccte. O órgão expede as regulamentações administrativas e implementa regulações sob a supervisão da seção de Imigração do Ministério do Interior. A Administração da Migração possui um papel relevante durante o processo de migração, pois comunica formalmente a aprovação do processo de autorização para trabalho às autoridades consulares francesas localizadas no exterior, onde o visto será obtido pelo estrangeiro.

De acordo com a publicação Mipex, a França tem convivido com um número menor de imigrações permanente, reunião familiar e naturalizações.

Quanto aos vistos de trabalho, devem ser patrocinados por um empregador estrangeiro ou francês e serão submetidos às autoridades trabalhistas (Direccte), com exceção dos vistos baseados em alta qualificação.

As transferências entre empresas para estadas temporárias são normalmente concedidas por um período de até três anos e o visto de trabalho permite ao cônjuge do titular do visto trabalhar na França, desde que o prazo do visto do titular seja superior a seis meses.

Os vistos para pessoas altamente qualificadas e para os considerados talentos foram criados com o propósito de atrair estrangeiros com qualificações consideradas excepcionais que possam contribuir com o desenvolvimento econômico, intelectual, científico, cultural e humanitário do país. O pedido de visto é normalmente processado por 
meio do consulado francês do país de origem do candidato e a validade é de três anos, renovável, porém com certas restrições, a depender da nacionalidade do candidato.

Vistos para atividades de baixa qualificação se submetem a uma lista de ocupações, cujas vagas não são preenchidas pelo mercado de trabalho local, com intuito de permitir o ingresso de estrangeiros por curtos períodos de tempo.

Os vistos mais comuns para trabalhar na França são: a) visto para trabalhador assalariado temporário, com validade de até um ano, mediante contrato de trabalho; b) trabalho temporário com contrato de trabalho, para período inferior a um ano; c) trabalho sazonal, mediante contrato de trabalho para atividades integrantes de lista anual, com prazo de validade de até 12 meses; d) autorização temporária de trabalho mediante contrato de trabalho por até nove meses; e) empregado em transferência internacional entre empresas do mesmo grupo econômico, por até três anos, porém o visto só será concedido para indivíduos com vínculo empregatício com a empresa no exterior por pelo menos três meses antes do pedido do visto. ${ }^{140}$

Embora a França não possua um sistema de quotas baseado em determinado percentual de franceses em relação aos estrangeiros que determinada empresa deseja patrocinar para fins de trabalho na França, as autoridades trabalhistas locais levam em conta essa proporção em casos concretos envolvendo pedidos de vistos de trabalho diretamente patrocinados por empresas locais ou estrangeiras.

Segundo os dados disponibilizados no Mipex, a França não incrementou nenhum direito em relação à migração a trabalho. ${ }^{141}$

Apesar da promessa do governo de reduzir determinadas restrições de modo a facilitar o ingresso de trabalhadores qualificados, as pesquisas do Mipex demonstram que o país continua a rejeitar a promoção de igualdade de oportunidades de acesso às vagas de emprego mais qualificadas aos nacionais de países terceiros. Os trabalhadores migrantes são normalmente aprovados para ingresso com intuito de prestar serviços em vagas onde há necessidade de mão de obra, em vez das oportunidades para as quais são qualificados.

\footnotetext{
140 Pascal Guinot, Global Mobility Handbook 2010, p. 121.

141 Disponível em: <http://www. Mipex.eulfrance>. Acesso em: 28 set. 2013.
} 
Em matéria de aquisição da nacionalidade francesa, a legislação francesa é considerada restritiva. A decisão é normalmente delegada às autoridades locais e sem direito a uma segunda decisão, como resultado de um projeto iniciado em 2009 com o propósito de agilizar os serviços e as decisões de naturalização. Todavia, segundo a avaliação do Mipex, a reforma também aumentou os casos de discriminação. Há casos em que trabalhadores migrantes com similar experiência receberam decisões distintas, sendo aceitos em uma localidade e rejeitados em outras, conforme as condições de ingresso foram interpretadas.

A França também foi analisada em relação à proteção contra discriminação e nesse tema a Lei n. 2008-496 estabelece proibição à discriminação baseada em raça, origem e sexo. Entretanto, a lei não dispõe sobre proteção à discriminação baseada em nacionalidade.

Quanto ao acesso à Previdência social, Brasil e França firmaram em 22.04.2013 o protocolo do Acordo Bilateral de Previdência Social Brasil-França, possibilitando que trabalhadores transferidos pela empresa de um país para o outro possam continuar contribuindo no país de origem durante o período de 24 meses, com possibilidade de prorrogação por igual período, evitando assim a dupla tributação sobre os salários. O acordo está em processo de ratificação pelos dois países. ${ }^{142}$

Em final de 2013, durante visita do presidente François Hollande a Brasília, o governo francês tomou a iniciativa de propor ao governo brasileiro a assinatura de um acordo para a criação de um visto específico que permitirá um intercâmbio destinado a jovens entre 18 e 30 anos, interessados em viajar a turismo e para trabalho, no Brasil e na França, por até um ano.

142 Disponível em: 〈http://www.3.dataprev.gov.brlsislexlimagenslpaginasl02lbrasil_franca.pdf>. Acesso em: 28 set. 2013. 
O acordo turismo-trabalho - ou visto mochileiro, como está sendo chamado pelo governo - ainda precisa ser ratificado por Câmara e Senado, já que implica em mudança na legislação brasileira. ${ }^{143}$

\subsubsection{Alemanha}

Índice Mipex: 57 (levemente favorável)

A Alemanha é formada por 16 Estados (Bundeslander) e sua população é de aproximadamente 82 milhões, sendo o país de maior população da UE.

O ordenamento jurídico da Alemanha é estabelecido em âmbito federal, e a maioria das leis é promulgada pelo Parlamento com abrangência federal, embora uma significativa parte da legislação advém das Diretivas da UE. ${ }^{144}$

Em matéria de imigração e cidadania, aplicam-se a Lei de Cidadania (Staatsangehorigkeitsgesetz) e a Lei de Residência (Aufenthaltsgesetz), simultaneamente com as regulações sobre emprego (Beschaftigungesverordnung), as quais garantem condições de ingresso e permanência.

As autoridades envolvidas no processo de migração, desde a expedição dos vistos e autorizações de trabalho, são os consulados da Alemanha localizados no exterior e os Escritórios Nacionais de Assuntos Exteriores (Auslanderberhorde).

Os principais vistos relacionados à migração a trabalho são: a) vistos para indivíduos altamente qualificados, por período indeterminado, aplicáveis a cientistas com conhecimento especial, professores, especialistas e executivos com experiência profissional especial, cujo salário seja superior ao limite previsto para ter direito a pensões sob o sistema previdenciário local (66.000 Euros anuais - base 2012); b) visto para executivos, pelo mesmo período do contrato ou da designação como representante da

\footnotetext{
143 Disponível em < http://www.itamaraty.gov.br/sala-de-imprensa/notas-a-imprensa/atos-assinados-nopalacio-do-planalto-por-ocasiao-da-visita-de-estado-do-presidente-da-republica-francesa-francoishollande-brasilia-12-de-dezembro-de-2013/?searchterm=vistos 1 ano frança> Acesso em: 15 dez. 2013.

144 Gunter Mavers, em capítulo publicado no livro no livro Global Mobility, p. 90-103.
} 
empresa patrocinadora do visto. Aplica-se a executivos com poderes de representação de uma entidade empresária; c) visto para atividades comerciais, com validade de 12 meses, permitindo a permanência por um período de até três meses a cada entrada, aplicados a empregados de empresas com atividades na Alemanha, com o propósito de representar a empresa empregadora na execução de atividades e contratos comerciais; d) vistos para treinamento, por até três meses para empregados de empresas do mesmo grupo econômico, com o propósito de participarem de atividades de treinamento; e) transferências entre empresas do mesmo grupo econômico, sujeito à verificação de ausência de impactos no mercado de trabalho local. A verificação é dispensada para candidatos que possuam diploma de curso universitário ou superior.

Segundo o Mipex, apesar de a Alemanha apresentar políticas migratórias mais favoráveis, sendo o país com o sexto maior índice no Mipex, as políticas de migração a trabalho ainda não foram totalmente reformadas para permitir aos trabalhadores liberdade de combinar suas competências e qualificações às vagas de trabalho locais. Os procedimentos atuais para o ingresso de trabalhadores qualificados de países terceiros à UE ainda são complexos e morosos.

Em relação à cidadania, a Corte Federal Constitucional estabeleceu em cinco anos o período para o acesso à cidadania. Os candidatos têm acesso a um dos procedimentos mais seguros e profissionais de testes para aferição de assimilação da cultura alemã para fins de concessão da cidadania.

Quanto à proibição de discriminação, a legislação, segundo a avaliação Mipex, é mais avançada do que os padrões da UE, incluindo proibição à discriminação por critério de raça, etnia e religião. Entretanto, segundo agências não governamentais, o país ainda não possui mecanismo para efetivamente coibir práticas antidiscriminatórias, tendo sido apontado que a Agência Federal Antidiscriminação possui limitados poderes para prestar assistência às vítimas de discriminação.

Em matéria de Previdência Social, o Brasil firmou com a Alemanha, em 03.12.2009, o Acordo bilateral de Previdência Social. O Acordo foi promulgado pelo Decreto 8.000, de 08.05.2013, com vigência imediata, e prevê, em síntese, a possibilidade de o empregado se deslocar para prestar serviços para o mesmo empregador em dois 
países, continuar a contribuir para a Previdência do país de origem, durante os primeiros 24 meses, usufruindo das prestações previdenciárias previstas no sistema do país de destino, com eventuais limitações previstas no Acordo. ${ }^{145}$

\subsubsection{Espanha}

Índice Mipex: 63 (Medianamente favorável) ${ }^{146}$

A Espanha é o segundo maior país da UE, com uma população aproximada de 46.157.822 pessoas, possui um sistema legal formado pela Constituição, estatutos e regulamentos. A principal fonte legislativa em matéria de migração é a Lei Orgânica $n$. 2/2009, o Decreto Real n. 4/2011 e o Decreto Real n. 240/2007, sobre a entrada livre circulação e residência de cidadãos da UE.

A situação dos nacionais de países terceiros à UE é regulada na Lei n. 2/2009 e Regulamento RD n. 557/2011. ${ }^{147}$

Os principais vistos para a migração a trabalho são: a) visto temporário de trabalho e residência, com validade de três meses, permite o ingresso e a permanência no país com o propósito de empreender atividade remunerada ou sob vínculo de emprego previamente autorizado pelas autoridades migratórias; b) transferências entre empresas integrantes do mesmo grupo econômico, com validade de um ano, sendo exigido pelo menos um ano de vínculo com a empresa no país de origem do candidato, antes de dar início ao pedido de visto. A lei espanhola permite a transferência entre empresas apenas para posições de gerência e diretoria e desde que o indivíduo continue vinculado à folha de pagamento da empresa no país de origem.

Apesar da crise econômica e do alto nível de desemprego, a Espanha foi considerada um dos países medianamente favoráveis à migração. O país utiliza os padrões da UE de forma a assegurar direitos de residência e de reunião familiar aos migrantes.

\footnotetext{
145 Disponível em: 〈http://www.3.dataprev.gov.brlsislexlimagens\paginas\02lbrasil_alemanha.pdf〉. Acesso em: 28 set. 2013.

146 Disponível em: <http://www.mipex.eu/spain>. Acesso em: 28 set. 2013.

147 Ana Garicano Solé, no livro Global Mobility, p. 208-213.
} 
Desde 2009, a Espanha vem adotando políticas para desencorajar a migração irregular, enquanto provê igualdade de acesso à educação e treinamento aos trabalhadores indocumentados e seus familiares.

Em 27.09.2012, foi promulgada a Lei n. 14/2013, que dispõe sobre medidas de apoio aos empreendedores e a sua internacionalização. $\mathrm{O}$ art. 2. ${ }^{\circ}$ do Título V contém disposições com o intuito de facilitar a entrada de estrangeiros no país por razões econômicas, desde que pertençam aos seguintes grupos: investidores; empreendedores; profissionais muito qualificados; pesquisadores; estrangeiros sujeitos a transferências entre empresas. $^{148}$

A nova lei define os investidores em razão do capital que possuem, sendo concedido o visto de residência ao estrangeiro que possuir 2 milhões de Euros em títulos da dívida pública ou 1 milhão de Euros em ações de empresas espanholas, ou, ainda, que comprovar a aquisição de propriedades em valor superior a 500 mil Euros no conjunto.

Vistos para profissionais qualificados são concedidos desde que patrocinados por empresas multinacionais que compõem grupo econômico com empresas espanholas em setores considerados estratégicos para a economia do país. A aprovação dos vistos é sujeita à prova de número superior a 250 empregados e investimento de 1 milhão de Euros na economia espanhola nos últimos três anos.

O acesso à cidadania está sujeito a um período entre quatro a seis anos de residência, todavia os procedimentos e os prazos ainda deixam a desejar.

Em relação às políticas antidiscriminatórias, segundo o Mipex, a Espanha está menos preparada para combater a discriminação baseada na nacionalidade do que a média dos países da UE. Os mecanismos de proteção incluem proibição à discriminação por etnia, raça e religião, mas não compreendem a proteção relativa à discriminação por nacionalidade. Ademais, o Conselho para a Promoção da Igualdade e Não Discriminação foi avaliado como ineficaz na proteção às vítimas de discriminação.

148 Disponível no Boletim Oficial del Estado, n. 233, sábado 28 de Septiembre de 2013, Sec. 1, p. 78787 788795. Madrid. España. 
O Conselho atua desde setembro de 2009, com foco no aconselhamento às vítimas e na condução de investigações que foram consideradas insuficientes para a proteção dos migrantes.

Em matéria de Previdência Social, Brasil e Espanha assinaram em 16.05.1991 o Convênio sobre Seguridade Social. Em 23.11.2005, foi assinado o Ajuste Administrativo, mediante o qual os dois países estabeleceram as medidas necessárias para a aplicação do convênio que permite ao empregado usufruir de benefícios como a aposentadoria por invalidez, idade, tempo de contribuição ou morte, mediante contribuição feita para um dos dois países, enquanto perdurar a sua permanência no território do outro país. $^{149}$

\subsection{North American Free Trade Agreement (Nafta)}

As negociações que deram origem ao Nafta iniciaram-se em 1990, entre os Estados Unidos, o Canadá e o México. Em dezembro de 1992, os três países assinaram, em San Antonio, Texas, o Tratado que criou o bloco econômico, ratificado pelo Congresso dos Estados Unidos em 17.11.1993.

O Nafta começou com um acordo avençado entre o Canadá e os Estados Unidos em 1989. Em 1. ${ }^{\circ} .01 .1994$, o acordo incorporou o México, com o objetivo de dinamizar a economia e aumentar o fluxo de capitais. O tratado do Nafta contempla 2.000 páginas, nas quais se delinearam as regras para o comércio internacional e investimentos entre os países-membros, sendo composto de oito seções, vinte e dois capítulos.

Segundo Mamede, observa-se que o tratado já incorporou na sua origem os princípios básicos da Organização Mundial do Comércio, que viria a ser criada em 1995, tais como: a) o princípio da nação mais favorecida, segundo o qual um benefício concedido a um país deve ser estendido aos demais; b) do tratamento nacional e da transparência. Ambos deveriam se tornar garantias para a fluidez do comércio e a integração natural dos países de forma a contribuir positivamente para a qualidade de vida das pessoas.

149 Disponível em: <http://www.mpas.gov.br/arquivos/office/3_081013-161952-232.pdf>. Acesso em: 26 set. 2013. 
Alguns dos aspectos mais importantes do Tratado se referem à eliminação de tarifas de centenas de produtos que circulam entre os países, a leis especiais para os setores da agricultura, automóveis, comércio têxtil, telecomunicações e serviços financeiros. A formação do Nafta não objetivou uma integração nos moldes da União Europeia, sendo seu objetivo restrito à liberalização comercial, não contendo nenhuma previsão de unificação política dos países ou qualquer coordenação de políticas macroeconômicas.

De fato, segundo dados da subsecretaria de negociações do México, o volume de comércio entre os três países nos primeiros 14 anos de vigência do Tratado aumentou em 649,1 bilhões de dólares. ${ }^{150}$

Os países-membros instituíram três secretarias nacionais, cujas responsabilidades consistem em assessorar o Conselho ministerial do Nafta com informações, relatórios e estudos voltados ao incremento dos objetivos do bloco.

A estrutura enxuta do bloco revela sua vocação exclusiva ao aumento do intercâmbio de mercadorias. Com efeito, apesar do natural aumento do fluxo de pessoas em busca das oportunidades econômicas propiciadas pela integração de pelo menos duas grandes potências, Canadá e Estados Unidos, o tema da migração aparece timidamente no Capítulo 10, Parte 5, sobre investimentos, serviços e assuntos relacionados, e o Capítulo 6 trata da entrada temporária de pessoas para fins de negócios.

Na prática, entretanto, os investimentos estrangeiros ocorreram de forma muito mais esporádica do que as perspectivas iniciais. Uma vez assinado o acordo, o México tratou de adaptar-se a um nível de competitividade internacional, promovendo reformas estruturais que propiciaram maior participação do capital privado e consequente redução do investimento público, na expectativa de que fosse suprido pelo investimento dos países ricos do bloco.

No entanto, Berta Luján, sindicalista mexicana, denuncia que os investimentos, especialmente dos Estados Unidos foram direcionados a regiões fronteiriças e ao norte do

150 Disponível em: <http://www.nafta-sec-alena.org/Default.aspx?tabid=90\&language=en-US>. Acesso em: 7 out. 2013. 
país onde se encontram as chamadas "indústrias maquiladoras", que importam componentes industriais e finalizam o processo de produção, exportando os bens prontos.

Com isso, os trabalhadores não usufruíram de nenhum benefício do pífio investimento estrangeiro, que não proveu nenhum tipo de qualificação técnica ou assistência social diferenciada a esse contingente de trabalhadores de baixa renda.

Um balanço dos oito primeiros anos de vigência do tratado, elaborado por especialistas consultados pelo "El Observador Econômico", resultou no consenso de que o valor do salário mínimo ficou estagnado, o número de empregos criados em decorrência do Tratado foi inferior ao esperado, e a maior parte se concentrou no setor das "maquiladoras". Houve deterioração do meio ambiente e uma aceleração no êxodo da população rural para as cidades, em busca de melhores oportunidades e de uma rota que os permita migrar para os Estados Unidos. ${ }^{151}$

Segundo Truett, foram encontradas evidências de que o Tratado contribuiu favoravelmente para o crescimento das indústrias maquiladoras de 1994, porém em desfavor dos demais segmentos econômicos. A mesma constatação é feita por Polaski, que acrescenta a frustrante queda nos rendimentos dos trabalhadores do segmento de maquiladoras e a redução de empregos no setor de agricultura, em razão do incremento das importações. ${ }^{152-153}$

O Anexo 1603 dispõe a garantia de ingresso de pessoas sem a obtenção de uma autorização de trabalho, desde que preenchidas as regras migratórias de cada país. Ressalvas maiores são colocadas em relação aos trabalhadores mexicanos, como salienta Mamede. Enquanto Estados Unidos e Canadá “podem usufruir de ampla mobilidade no território econômico do Nafta, é exigido dos trabalhadores mexicanos, independente de seu cargo, visto para permanecerem nos Estados Unidos". O Canadá não faz tal exigência. ${ }^{154}$

151 Disponível em: <http://www.elobservatorioeconomico.com/archivoantero;127/portoda4.htm〉. Acesso em: 8 out. 2013.

152 Lila J. Truett, Dale B. Truett, em artigo publicado na Revista Contemporary Economic Policy, p. 2-5.

153 Sandra Polaski, Jobs, wages, and household income, p. 20.

154 Anna Paula Ribeiro Araujo Mamede, artigo publicado em 22.03.2010. Disponível em: <http://www.pucminas.br/conjuntura>. Acesso em: 7 out. 2013. 
A discriminação é confirmada por Rabinovich, que ressalta o tratamento privilegiado aos cidadãos canadenses interessados em migrar para os Estados Unidos, para os quais não se exige autorização de trabalho e não há restrições em função das quotas anuais para migrantes. Os mexicanos, ao contrário, submetem-se obrigatoriamente às exigências da autorização de trabalho e o seu processo deve ser iniciado obrigatoriamente por meio dos consulados americanos no México. Há, ainda, uma limitação no período máximo que os mexicanos poderão permanecer no país, equivalente a um ano. ${ }^{155}$

O tratamento lacônico à questão migratória no Tratado foi justificado pelos Estados Unidos, segundo Mamede, à vista de que o processo da modernização produtiva que o tratado proporcionaria ao México teria resultados positivos na economia local e nas condições de trabalho de uma forma geral, de modo que, a longo prazo, os mexicanos não teriam mais motivos para emigrar.

\subsubsection{Os Estados Unidos}

Índice Mipex: 62 (medianamente favorável) ${ }^{156}$

Os Estados Unidos da América são integrados por 50 Estados e um distrito federal. A Constituição é a norma fundamental do ordenamento jurídico americano, porém os governos estaduais têm competência para instituir várias leis vinculantes nos limites de seus respectivos territórios.

Com uma população estimada em 308.745.538 pessoas, o país figura como a maior economia mundial, o que coloca em evidência as suas políticas migratórias para o resto do mundo. ${ }^{157}$

Em linhas gerais, pode-se dizer que o fatídico 11 de setembro de 2001 foi o divisor de águas nas políticas migratórias dos Estados Unidos, provocando uma ruptura

55 Salomon Chiquiar-Rabinovich, The American continente region, p. 15-16.

156 Disponível em: <http://www.mipex.eu/usa>. Acesso em: 26 dez. 2013.

157 Poorvi Chothani, The United States of America, Global mobility. An overview for Human Resource Professionals, p. 271-273. 
com a trajetória de incremento dos direitos humanos no país, que vinha se tornando cada vez mais presente nas discussões sobre os rumos das políticas migratórias.

Lewandowski identifica que os Estados Unidos desenvolveram uma nova doutrina militar por conta dos atentados de 11 de setembro, a qual abandonou qualquer sofisticação, guiada pela frase "atacar primeiro". ${ }^{158}$

A primeira medida pós-11 de setembro foi a extinção da agência responsável pela concessão de vistos e a criação, em 2002, de uma superagência de segurança, o Department of Homeland Security (DHS). Segundo Reis, o DHS já figura como o maior departamento do governo norte-americano e é responsável por todos os assuntos pertinentes à segurança nacional, entre eles a migração. ${ }^{159}$

Reis acrescenta, todavia, que as tensões entre os interesses nacionais na concessão de vistos e as disputas de grupos com vários interesses opostos já existiam antes dos atentados terroristas, identificando a década de 1980, em que houve um crescimento da migração, especialmente a ilegal, como o fio condutor para opiniões contra e a favor dos migrantes.

De um lado estavam os que defendiam regras mais rígidas ao argumento de que os migrantes ilegais atuavam em competição desleal com os cidadãos americanos e causavam prejuízos ao Estado, em virtude do uso de escolas, hospitais e da ausência de respeito aos valores e às instituições do país. E, de outro lado, os que defendiam políticas voltadas aos direitos humanos.

A autora identifica os mexicanos como os migrantes que foram particularmente estigmatizados em razão das ideias acima expostas, e, sob a sombra das crises econômicas, eram os primeiros alvos de expulsão, seguidos dos outros migrantes de origem latina, embora em posição mais favorável do que os mexicanos.

158 Enrique Ricardo Lewandowski, Globalização, regionalização e soberania, p. 46.

159 Rossana Rocha Reis, Migrações: casos norte-americano e francês. Esd. Av., São Paulo, v. 20, n. 57, ago. 2006. Disponível em: <http://www.scielo.php?script=sci_arttex\&pid=SO103-4013206000200006\&Ing=en \&nrm=iso>. Acesso em: 8 out. 2013. 
Em 2002, a promulgação do Enhanced Border Security and Visa Reform Act representou maior rigidez no controle das fronteiras, proibindo a emissão de vistos da modalidade non-immigrant para nacionais de países considerados como refúgio de terroristas, o que automaticamente impactou negativamente na situação de muitos migrantes de religião muçulmana. ${ }^{160}$

Tradicionalmente, os Estados Unidos dão preferência ao migrante qualificado.

As mudanças na legislação migratória dos Estados Unidos refletem essa intensa preocupação em restringir o acesso de migrantes e erradicar a migração ilegal. Reflexo direto dessa realidade é o recente Projeto de Lei n. 744, aprovado pelo Senado em 02.10.2013, denominado The Border Security Economic Opportunity, and Immigration Modernization Act (H.R.15). ${ }^{161}$

O projeto objetiva valorizar as medidas voltadas à segurança nacional e ao controle de fronteiras, com medidas drásticas para a identificação de migrantes ilegais. As disposições mais relevantes da nova lei consistem em:

i. expansão da aplicação do programa "E-Verify", pelo qual empregadores deverão confirmar a situação migratória dos novos empregados, mediante acesso aos dados oficiais. O uso do sistema foi propiciado, em caráter facultativo aos empregadores, a partir de setembro de 2009, e se intensificou rapidamente, alcançando em 2011 o número de 243.000 empregadores cadastrados para a sua utilização. Há uma intensa discussão entre manter o "E-Verify" como uma ferramenta de apoio aos empregadores ou transformá-lo em programa de uso obrigatório, mediante a implementação de medidas punitivas; ${ }^{162}$

${ }^{160}$ Luciana Unis Coentro, Políticas públicas e gestão das migrações internacionais no Brasil: uma reflexão sobre os migrantes qualificados, p. 55.

161 Disponível em: <http://www.globalimmigrationconsel.com>. Publicado em 7 out. 2013. Acesso em: 8 out. 2013.

162 Disponível em: <http://www.Migrationinformation.orglfeatureldisplay.cfm?ID=846>. Acesso em: 8 out. 2013. 
ii. incrementar projetos que visam direcionar ao Departamento de Polícia de Fronteiras (Department of Homeland Security) a competência para traçar estratégias para tornar efetiva a segurança nas fronteiras;

iii. implantar um sistema de identificação biométrica em todos os portos de ingresso no país;

iv. instituir novas categorias de vistos para novos migrantes e visitantes;

v. introduzir modificações no visto $\mathrm{H}-1 \mathrm{~B} / \mathrm{L}$ que atualmente se destina ao recrutamento e contratação de profissionais estrangeiros para trabalho no país por um período inicial de três anos, renovável por igual período. A concessão do visto já é extremamente restritiva, a exemplo das ofertas de trabalho, que devem ser limitadas a determinadas ocupações, nas quais normalmente se exigem no mínimo um diploma universitário e a comprovação de ausência de impactos negativos aos cidadãos americanos. $\mathrm{O}$ visto $\mathrm{H}-1 \mathrm{~B}$ está sujeito a um sistema de quota anual, definida pelo Congresso. Atualmente o número máximo de vistos é de 65.000 para candidatos a uma vaga de emprego e 20.000 para estudantes interessados em cursos de pós-graduação, mestrado e doutorados oferecidos por universidades americanas;

vi. a inclusão da cobrança de uma taxa de 1.000 dólares para o processamento da autorização de trabalho aos migrantes em determinados programas;

vii. expandir as categorias de vistos que atualmente são concedidos com o propósito de residência e trabalho para migrantes. Atualmente são cinco categorias. O visto EB-1 é destinado aos migrantes com extraordinária competência, a exemplo de renomados professores e pesquisadores, além de altos executivos de empresas multinacionais. O visto EB-2 se aplica a profissionais portadores de títulos universitários que comprovam habilidades excepcionais. O visto EB-3 destina-se a profissionais com experiência comprovada em determinada área e outros trabalhadores. O visto EB-4 é uma categoria aplicada a religiosos, pessoas que anteriormente já residiram no país e outros. O visto EB-5 destina-se a pessoas que decidem investir no país, sob o compromisso de criar e manter o mínimo de 
dez empregos para cidadãos americanos. A nova proposta consiste em aplicar categorias ainda mais específicas aos candidatos à residência permanente no país (as novas categorias são E, F, H, L O, P e V) e uma nova categoria, $\mathrm{W}$, para candidatos temporários, sem intenção de residência permanente no país;

viii. expandir as regras de portabilidade de vistos $\mathrm{O}-1$ destinados a migrantes que demonstrem extraordinárias habilidades reconhecidas nacional e internacionalmente. $\mathrm{O}$ visto é concedido em caráter temporário com o objetivo de permitir ao candidato dar continuidade ao trabalho restrito à área de suas habilidades.

O primeiro reflexo da aprovação do Projeto de Lei foi a suspensão, a partir de 1. .10 .2013 , do processamento das autorizações de trabalho para migrantes, anunciada pelo Instituto de Certificação do trabalho estrangeiro (Office of Foreign Labor Certification). A indisponibilidade afetará diretamente as empresas cujos vistos H1-B de empregados migrantes estejam com a data de validade próxima de expirar e os candidatos a novas vagas de emprego.

Do exposto, não é difícil perceber que a política migratória dos Estados Unidos mostra clara tendência restricionista que se intensificou a partir de outubro de 2013, com a reforma da lei migratória. Há, nitidamente, uma abertura voltada à migração seletiva e o repúdio à migração de trabalhadores de baixa qualificação. Quanto aos migrantes ilegais, o cenário indica que medidas voltadas à expulsão se intensificarão nos próximos anos.

Os debates envolvem, além da intensificação do controle das fronteiras, a avaliação sobre as oportunidades concedidas aos migrantes com situação migratória regular. Para este contingente, verificam-se boas oportunidades de trabalho, embora em ocupações consideradas inferiores às disponíveis aos nacionais.

De acordo com o Índice Mipex, os Estados Unidos retrocederam em dois aspectos de suas políticas migratórias: o primeiro está relacionado à rigidez nas medidas de segurança contra os migrantes ilegais, cujo ingresso e permanência são fortemente combatidos. O segundo decorre da dificuldade de obter a cidadania americana. 
O processo migratório dos Estados Unidos é complexo, submete os candidatos ao pagamento de taxas de valor elevado, exige extensa documentação e não oferece segurança e transparência, aspectos que colocam o país em desvantagem, quando comparado com cerca de 29 países da Europa e em relação ao Canadá. ${ }^{163}$

Em contrapartida, indivíduos com a situação migratória regular desfrutam, conforme já dito, de uma condição considerada boa pelo Índice Mipex, com acesso a oportunidades de trabalho, mecanismos ágeis e favoráveis para a abertura de negócios, e há auxílio das agências governamentais na busca de vagas de trabalho, ainda que em posições não mais baixas do que a qualificação do migrante, uma vez que em muitos Estados o migrante não consegue obter o reconhecimento do diploma de graduação emitido por instituições estrangeiras.

Quanto às leis contra discriminação e garantia de igualdade de oportunidades, os Estados Unidos têm incrementado leis estaduais no sentido de proibir discriminação com base na nacionalidade, origem ou cidadania, raça, etnia e crenças religiosas.

Nesses aspectos, a pesquisa do Mipex relevou que o país possui um dos mais eficazes mecanismos em favor das vítimas de discriminação, dispondo de organizações especialmente dedicadas a ingressar com ações civis, inclusive para os migrantes que não têm fluência no idioma inglês. O Departamento de Justiça e Direitos Civis promove ações no sentido de informar aos migrantes sobre os seus direitos e a investigação de denúncias de discriminação, na grande maioria trazidas por entidades de defesa das minorias.

Para fechamento deste tópico, pareceu-nos oportuno reproduzirmos um trecho do diálogo do Professor Michio Kaku, físico americano formado pela Universidade Harvard, resumindo a visão sobre a política migratória atual dos Estados Unidos:

Como é que a comunidade científica dos Estados Unidos não entra em colapso? Deixe-me dizer algo, uma coisa que alguns de vocês não podem saber. A América tem uma arma secreta, essa arma secreta é o H1B. Sem o H1B, o estabelecimento científico deste país entraria em colapso. Esqueça o Google! Esqueça o Vale do Silício! Não haveria Vale do Silício sem o H1B. E você sabe o que H1B? É o visto dos gênios, ok? Você percebe que, nos Estados Unidos, 50\% de todos os

163 Dados disponíveis em: 〈http://www.mipex.eu/usa〉. 
doutorandos são de origem estrangeira. No meu sistema, um dos maiores nos Estados Unidos, $100 \%$ dos doutorandos são de origem estrangeira. Os Estados Unidos são um ímã sugando todos os cérebros do mundo $[\ldots] .{ }^{164}$

\subsection{Mercosul}

A migração intrarregional nos países da América do Sul não é tão significativa em termos numéricos, quanto o é pelas suas características de irregularidade.

É verdade que o fluxo de migrantes para o Brasil aumentou cerca de $86 \%$ na última década, atingindo um contingente de 268 mil migrantes segundo pesquisa divulgada pelo IBGE para o ano de 2010, porém é ainda insignificante comparado com o fluxo para os países da Europa e da América do Norte. ${ }^{165}$

Conquanto pareça paradoxal, o Mercosul tem início na história de desconfiança e enfrentamento entre Brasil e Argentina, pela hegemonia sobre o continente sulamericano. Segundo Freitas, foi a crise econômica de 1980 que, de certo modo, fez com que o protagonismo perdesse espaço e viabilizou o início de um processo de integração entre Brasil e Argentina, que se deu em um momento político favorável para o Brasil, que, embora atravessava a crise da dívida externa, iniciava um processo de redemocratização com a promulgação da nova Constituição Federal de 1988, que dispõe sobre a "integração latino-americana como um de seus princípios nas relações internacionais do Brasil”. ${ }^{166}$

Em 1991, Argentina, Brasil, Paraguai e Uruguai assinaram o Tratado de Assunção para a criação do Mercado Comum do Sul, fruto de um longo processo de construção da integração sul-americana que teve seu início com a criação da Comissão

164 Tradução para o português extraída do relatório Imigração, 1. a série de Estudos Estratégicos sobre Políticas Públicas (DAPP), Cesar Cunha Campos, Diretor da FGV Projetos e Marco Aurélio Ruediger, diretor análise de políticas públicas, 2013, São Paulo: FGV, p. 89. Disponível em: <http://fgvprojetos.fgv.br/sites/fgvprojetos.fgv.br/files/estudo_24.pdf>, acesso em: 2 jan. 2013. Áudio do diálogo disponível em: 〈http://www.youtube.com/watch?v=NK0Y9j_CGgM>. Acesso em: 2 jan. 2013.

165 Disponível em: <http://www.ibge.gov.brlhomelestatisticalpopulacaolcenso2010ไmigracao>. Acesso em: 21 set. 2013.

166 Antonio de Jesus da Rocha Freitas, Manual do Mercosul: globalização e integração regional, p. 242. 
Econômica das Nações unidas para a América Latina e Caribe (Cepal), em 1948, por iniciativa do Conselho Econômico e social da ONU. ${ }^{167}$

O Chile aderiu como parceiro posteriormente. A adesão da Venezuela é negociada por meio do Protocolo assinado em 2006. A Bolívia é o mais recente país a negociar seu ingresso gradual ao Mercosul, em até quatro anos a contar da assinatura do Protocolo de 2012, em 07.12.2012. ${ }^{168}$

O Paraguai teve suspenso o direito de participar nos órgãos do Mercosul, conforme deliberação adotada em 29.06.2012, em resposta à destituição do poder do então Presidente Fernando Lugo. A suspensão teve como justificativa que o processo de impeachment de Lugo não teria respeitado os preceitos legais. Após o monitoramento do processo eleitoral que resultou na eleição do novo Presidente, Horácio Cartes, a suspensão teve fim em 15.07.2013. ${ }^{169}$

Rodrigues destaca essa fase que se desenrolou nas décadas de 50 a 70 pela importância da regulação dos capitais e a inserção internacional das economias latinoamericanas e a formação de uma agenda focada na industrialização dos países-membros, no progresso tecnológico e na redução de desigualdades. ${ }^{170}$

Os anos 80 marcam um período de maior integração e cooperação entre a Argentina e o Brasil, na busca de redefinir parâmetros para a inserção internacional. Nesse sentido, a Declaração do Iguaçu, assinada entre os dois países em 1985, foi decisiva para o início do processo de cooperação em temas de interesse comum, tais como transporte, energia, infraestrutura e comunicação.

Com a intenção de dar maior credibilidade ao processo de integração, viabilizou-se a entrada do Paraguai e Uruguai, em um momento em que a região antevia a

\footnotetext{
167 Disponível em: <http://www.mercorsur.intlinnoaportal\filel4002\1〈protocolo_adesao>. Acesso em: 21 jul. 2013.

168 Ibidem.

169 Disponível em: 〈http://www.Mercosur.intlinnovaportallfile\4677\1\declaracao-paraguai〉. Acesso em: 21 set. 2013.

170 Fernando Henrique Lemos Rodrigues, Lições que a Cepal deixou ao Brasil. Jornal da Unicamp, n. 347, <http://www.unicamp.brlunicamp_hojeljornalIPDFljul347pg09pdf>. Acesso em: 24 jul. 2012.
} 
possibilidade de fracasso das negociações da Rodada do Uruguai no General Agreement on Tariffs and Trade (GATT). ${ }^{171}$

Com a assinatura do Tratado de Assunção, o Mercosul dá o primeiro passo ao projeto de integração, com a criação da zona de livre-comércio, cujo objetivo seria a ausência de tributos e a livre importação, almejando os países signatários a aceleração do processo de desenvolvimento econômico e a intensificação do comércio com o resto do mundo.

Conforme dispõe o art. 1. ${ }^{\circ}$ do Tratado de Assunção, o objetivo do Mercosul é a livre circulação entre os países-membros de pessoas, bens, serviços e fatores de produção, a ser alcançada mediante a eliminação dos direitos aduaneiros, restrições tarifárias e outras medidas equivalentes. ${ }^{172}$

Outro passo importante para a integração dos países-membros foi o Protocolo de Ouro Preto, assinado em 17.12.1994, com o objetivo de definir o desenho institucional do bloco sul-americano, com o estabelecimento do Conselho do Mercado Comum, o Grupo do Mercado Comum, a Comissão de Comércio, a Comissão Conjunta e o Fórum Consultivo Econômico e Social. ${ }^{173}$

Em 2004 e 2005, outros dois importantes documentos entraram em vigor, o Protocolo de Olivos, que fora assinado em 2002 com o propósito de estabelecer o Tribunal Arbitral Permanente de Revisão do Mercosul (TPR), com sede na cidade de Assunção, no Paraguai.

A estrutura do Mercosul está atualmente assim desenhada: Conselho do Mercado Comum, Grupo do Mercado Comum, Secretaria do Mercosul, Comissão de Comércio, Comissão Parlamentar Conjunta e Parlamento do Mercosul, Foro Consultivo de Municípios, Estados Federados, Províncias e Departamentos, Foro Consultivo Econômico e Social; Fundo para Convergência Estrutural e Fortalecimento Institucional do Mercosul

171 Paulo Afonso Velasco, O Mercosul entre a geografia e a história: desafios, iniciativas e perspectivas, $\mathrm{p}$. 15.

172 Cássio Mesquita Barros, Perspectivas do direito do trabalho no Mercosul, p. 46-47.

173 Disponível em: <http://www.mercosur.intlshow:contentid=1318\&channel=secret>. Acesso em: 21 set. 2013. 
(Focem); Tribunal Administrativo-Trabalhista e Tribunal Permanente de Revisão do Mercosul.

Os órgãos com capacidade decisória são: o Conselho do Mercado Comum, o Grupo Mercado Comum e a Comissão do Mercosul. O Mercosul conta, ainda, como órgãos auxiliares, conforme previsto no art. $1 .^{\circ}$, parágrafo único, do Protocolo de Ouro Preto. Trata-se de grupos de trabalho, grupos técnicos, grupos de coordenadores, grupos ad hoc, subgrupos, reuniões de especialistas, reuniões ministeriais, comissões, fóruns e comitês técnicos.

Com o propósito de fortalecimento institucional, a Resolução n. 54, de 10.12.2003, do Grupo Mercado Comum, aprovou a criação do Tribunal Administrativo Trabalhista, denominado TAL, em razão das iniciais em espanhol: Tribunal Administrativo Laboral. A função do TAL é prover soluções às reclamações ajuizadas por parte dos funcionários da secretaria do Mercosul.

\subsubsection{Incorporação e aplicação das normas do Mercosul nos ordenamentos internos}

Conforme o Capítulo IV do Protocolo de Ouro Preto, as normas emanadas dos órgãos do Mercosul constituem-se verdadeiro ordenamento jurídico autônomo e terão caráter obrigatório aos países-membros e, se necessário, deverão ser incorporadas aos ordenamentos de cada país. Adverte que a aplicação do direito regional pode suscitar questões de ordem constitucional entre os integrantes dos Estados-membros. No entanto, a nosso ver, o Capítulo IV do Protocolo de Ouro Preto deixa claro que a incorporação automática das normas do Mercosul não se aplica a todos os casos, ao dispor que "[...] as normas emanadas dos órgãos do Mercosul terão caráter obrigatório e deverão, quando necessário, ser incorporadas aos ordenamentos de cada país". ${ }^{174}$

Rocha destaca, ainda, o procedimento de policromia que considera demorado para a efetiva entrada em vigor da legislação nacional:

174 Maria Elizabeth Guimarães Teixeira Rocha, A incorporação das normativas mercosulinas - UniCEUB. Disponível em: <http://www.publicacoesacademicas.uniceub.brlindex. phplarticle...11331>, p. 4-10. Acesso em: 22 set. 2013. 
a) após a aprovação da norma, os Estados nacionais deverão adotar as medidas necessárias para sua incorporação ao ordenamento jurídico nacional, comunicando à Secretaria Administrativa do Mercosul, quando estiverem internalizadas;

b) informada a incorporação por parte de todos os Estados, a Secretaria Administrativa do Mercosul comunicará a cada Estado-membro; e

c) a entrada em vigor ocorrerá simultaneamente nos Estados-membros dentro de 30 dias a contar da comunicação.

Ventura confirma a conclusão de que o processo é complexo e identifica como ponto de fragilidade o fato de que nenhum dos Estados-Partes do Mercosul possui até o momento um procedimento específico para a incorporação das normas comunitárias. ${ }^{175}$

Baptista também aponta que a supranacionalidade, nos mesmos moldes utilizados na União Europeia, encontra óbices no atual texto da Constituição do Brasil. ${ }^{176}$

Há, contudo, opiniões em sentido contrário, a exemplo de Bastos, que defende a posição de que o Brasil conta com a autorização da Constituição para a integração com outras nações e que seria inconcebível interpretar de forma restritiva a regra da Constituição de 1988, que dispõe no art. $4 .^{\circ}$ que o país rege-se nas suas relações internacionais pelos princípios da independência nacional, prevalência dos direitos humanos, autodeterminação dos povos, não intervenção, igualdade entre os Estados, defesa da paz, solução pacífica dos conflitos, repúdio ao terrorismo e ao racismo, cooperação entre os povos. $^{177}$

\subsubsection{Circulação de pessoas no Mercosul}

Não houve nenhuma referência específica à liberdade de circulação de pessoas no tratado de criação do Mercosul, denotando-se que temas como cidadania supranacional,

\footnotetext{
175 Deisy Ventura, As assimetrias entre o Mercosul e a União Europeia, p. 141.

176 Luiz Olavo Baptista, As instituições do Mercosul: comparações e prospectiva, p. 58-59.

177 Celso Ribeiro Bastos, Curso de direito constitucional, p. 184.
} 
liberdade de circulação e residência, facilitação de trânsito, migração a trabalho não constavam da agenda do Mercosul.

A Declaração Sociolaboral do Mercosul, assinada em 10.12.1998, no Rio de Janeiro, buscou aprimorar, ainda que timidamente, os direitos dos trabalhadores, conforme se observa das disposições do art. $4^{\circ}$, dedicado à proteção dos trabalhadores migrantes e fronteiriços. O texto faz referência ao direito dos migrantes de obter "ajuda, informação, proteção e igualdade de direitos e condições de trabalho reconhecidos aos nacionais do país em que estiverem exercendo suas atividades". Os Estados Partes se comprometeram, mediante a aludida Declaração, a adotar medidas objetivando a criação de normas e procedimentos destinados a melhorar as oportunidades de emprego e as condições de trabalho e de vida dos trabalhadores. ${ }^{178}$

A mobilidade de pessoas no âmbito territorial do Mercosul foi regulada com mais ênfase a partir das Decisões CMC n. 463/2000 e n. 47/2000, mediante as quais se estabeleceram canais privilegiados em aeroportos para a entrada de nacionais do EstadoParte, além da Bolívia e do Chile, com o único objetivo de permitir um tratamento preferencial e mais rápido de ingresso dos cidadãos oriundos desses fluxos regionais.

O acordo sobre residência só foi assinado 11 anos após a criação do Mercosul. Trata-se do Decreto CMC n. 28/2002. Por meio da assinatura desse acordo, os nacionais dos países-partes do Mercosul, Bolívia e Chile, têm o direito de residirem regularmente em outro país do bloco sem necessidade de fundamentar a atividade que desenvolverão, bastando comprovar a sua nacionalidade.

Quase sete anos depois, em 08.10.2009, o Decreto n. 28/2002 foi promulgado no Brasil. O Decreto Presidencial n. 6.964, de 29.09.2009 (correspondente ao Decreto Legislativo n. 210, de 20.05.2004) e o Decreto Presidencial n. 6.975, de 08.10.2009 (correspondente ao Decreto Legislativo n. 925, de 15.09.2005), estão em vigor no Brasil, finalizando um longo processo de facilitação de locomoção e residência para os cidadãos dos países-partes e associados do Mercosul. O Acordo abrange Argentina, Bolívia, Brasil, Chile, Colômbia, Equador, Uruguai, Peru e Venezuela.

\footnotetext{
${ }^{178}$ Disponível em http://www.dhnet.org.br/direitos/deconu/a_pdf/dec_sociolaboral_mercosul.pdf. Acesso em 28 out 2013.
} 
É importantíssimo esclarecer, portanto, que, desde 2009, os cidadãos argentinos, bolivianos, brasileiros, chilenos, paraguaios e uruguaios são titulares do direito de licitamente estabelecer residência em quaisquer dos países signatários, como migrantes regulares, com liberdade de trabalho e de empreendedorismo.

O direito de residência não é irrestrito. Os cidadãos do bloco contam com o direito de solicitar a residência temporária por até dois anos junto aos serviços de migração de quaisquer países signatários do Acordo. Devem, para tanto, apresentar documento de identificação ou passaporte válido e vigente, certidão de nascimento e comprovação do estado civil do indivíduo, certidão negativa de antecedentes criminais no país de origem ou naqueles em que residiu nos últimos cinco anos, além da declaração de ausência de antecedentes criminais internacionais e de certificado de sanidade psicofísica.

Noventa dias antes do término da residência temporária, o migrante poderá requerer a residência permanente, sendo para tanto exigidos: a) apresentação da certidão da residência temporária; b) prova de identidade; c) certidão negativa de antecedentes criminais; d) comprovação de meio de vida lícito que permita a subsistência do migrante e de seu grupo familiar de convívio; e f) pagamento da taxa de imigração.

O aspecto positivo é que, a partir do momento em que é aceito como residente temporário do país de destino, o cidadão passa a contar com ampla igualdade de tratamento, usufruindo de plenos direitos de circulação, ingresso e saída no território do país de destino.

Dentre os direitos assegurados no art. 9 do Acordo sobre Residência para Nacionais dos Estados-Partes, Bolívia e Chile, destacam-se:

- Igualdade de direitos civis, sociais, culturais e econômicos, sobretudo o direito de exercer toda atividade lícita nas condições que dispõem as leis, peticionar às autoridades, entrar, permanecer, transitar e sair do território das Partes, associar-se para fins lícitos e professar livremente seu culto.

- Reunião familiar aos membros da família que não possuam nacionalidade de um dos Estados-Partes será concedida por meio de autorização de residência por igual período a da pessoa da qual dependam. 
- Igualdade de tratamento com os nacionais: os migrantes usufruirão no território das Partes idêntico tratamento aos nacionais do país de destino no que concerne à aplicação da legislação trabalhista, especialmente em matéria de remuneração, condições de trabalho e seguro social.

- Compromisso em matéria previdenciária. As partes se comprometem a analisar a viabilidade de acordos de reciprocidade em matéria previdenciária. Nesse ponto, o Acordo segue a linha da Convenção da ONU, que não prevê reciprocidade plena e imediata.

- Remessas financeiras: os migrantes têm o direito de transferir recursos provenientes de suas economias pessoais ao país de origem, em conformidade com a legislação interna de cada uma das partes.

- Direitos dos filhos dos migrantes: os filhos de migrantes que nascerem em território de uma das Partes terão direito ao registro de seu nascimento e à nacionalidade conforme as respectivas legislações internas e são titulares do direito à educação em igualdade de condições com os nacionais de seu país de destino, inclusive os migrantes em situação irregular no país.

O Brasil também avençou acordos bilaterais com alguns países da América do Sul, a exemplo de residência permanente com o Uruguai, assinado em 09.07.2013, mediante o qual nacionais de um e outro Estado podem requerer a residência permanente no outro país, sem a necessidade do período provisório de dois anos. ${ }^{179}$

Assuntos trabalhistas, de emprego e de seguridade social passaram também gradualmente a constar da agenda a partir da criação do Conselho do Mercado Comum. Entretanto, como ressalta Husek, "o aspecto social continua em segundo plano no Mercosul", persistindo enorme carência de instrumentos hábeis à proteção do trabalho e dos trabalhadores, que envolvem, segundo o autor, a necessidade de regras sobre direitos e

179 Disponível em: <http://dai-mre.serpro.gov.br/atos-internacionais/bilaterais/2013/acordo-entre-arepublica-federativa-do-brasil-e-a-republica-oriental-do-uruguai-sobre-residencia-permanente-com-oobjetivo-de-alcancar-a-livre-circulacao-de-pessoas/at_download/arquivo>. Acesso em: 13 out. 2013. 
deveres em geral, tanto na execução dos contratos quanto na solução dos litígios e até mesmo sobre a atuação sindical. ${ }^{180}$

Não resta dúvida de que o acordo de integração econômica do Mercosul, que, todavia, não está concluído, como ressalta Freitas, trata-se de um lento processo de integração em plena construção, que ainda assim consegue ultrapassar estigmas entre os países e avançar nesse processo, que trabalha como realismo e "sem pretensões ufanistas típicas do caráter ibero-americano", e assim vem acentuando o fluxo de migração internacional, mais precisamente em países limítrofes, seguindo as novas rotas comerciais que vão sendo estabelecidas, e exigem estudar a necessidade de políticas sociais alinhadas com a gramática de direitos humanos. ${ }^{181}$

${ }^{180}$ Carlos Roberto Husek, Curso básico de direito internacional público e privado do trabalho, p. 157.

181 Antonio de Jesus da Rocha Freitas, Manual do Mercosul: globalização e integração regional, p. 330-331. 


\section{Capítulo 3 \\ O DEBATE NACIONAL SOBRE A MIGRAÇÃO \\ A TRABALHO}

\subsection{Breve histórico}

\subsubsection{Período pré-Constituição de 1988}

O Brasil, assim como a maioria dos países do mundo, não passou incólume à rejeição do estrangeiro. Carvalho Ramos relembra o período em que vivemos sob a égide da Constituição de 1824, de caráter extremamente antidemocrático, em que praticamente nada havia em termos de disposições de direito ingresso do estrangeiro. ${ }^{182}$

Vivenciamos uma fase de abertura com a necessidade de povoamento do País, em que houve até mesmo a abolição do passaporte, em 1890. O Decreto n. 6.455, de 19.04.1907, instituiu o chamado "Serviço de Povoamento do Solo Nacional", objetivando o preenchimento de áreas pouco habitadas ou deserta com migrantes que ingressassem no país com o propósito de se fixarem como proprietários rurais. ${ }^{183}$

Todavia, assim como os países desenvolvidos, o Brasil também cedeu à xenofobia em grande parte como resposta às levas de migrantes italianos politizados que pressionavam por melhores condições de vida. Assim, em 1934, a restrição ao ingresso de estrangeiros figurou pela primeira vez na Constituição Federal, mediante limitação do número de estrangeiros e restrições a sua fixação em determinadas regiões. $\mathrm{O}$ art. $121, \S$ 7. ${ }^{\circ}$, prescrevia sobre a proibição da "concentração de imigrantes em qualquer ponto do território da União, devendo a lei regular a seleção, localização e assimilação do alienígena". ${ }^{184}$

182 André de Carvalho Ramos, Direitos dos estrangeiros no Brasil, a imigração, direito de ingresso e os direitos do estrangeiros, p. 721-745.

183 Leandro Moreira Valente Barbas, Imigração de gestores de empresas transnacionais, expatriação, proteção à mão de obra nacional e desenvolvimento, p. 18.

184 Disponível em: <http://www.planalto.gov.br/ccivil_03/Constituicao34.htm>. Acesso em: 2 out. 2013. 
A Constituição de 1967 atribuiu à lei a possibilidade de disciplinar o ingresso e permanência e até proibir a entrada de estrangeiros com base em motivos econômicos, sociais e raciais. ${ }^{185}$

A Constituição de 1946 eliminou o sistema de cotas, restaurando a liberdade de ingresso, com restrições que se repetiram nas de 1967 e $1969 .{ }^{186}$

Em 1980, paralelamente à Constituição em vigor, desenvolveu-se toda uma produção legislativa fragmentada e incidental que se conheceu como o Estatuto do Estrangeiro - Lei 6.815, de 19.08.1980 -, com regras voltadas à segurança nacional e que perdura até hoje. As disposições do Estatuto seguem abordadas adiante, em item específico.

\subsubsection{Período pós-Constituição de 1988}

A Carta de 1988, identificada como a constituição cidadã, reconhece igualdade de direitos entre estrangeiros e nacionais, e a doutrina tratou de flexibilizar algumas das duras regras impostas ao migrante, considerando que os estrangeiros são titulares de direitos decorrentes dos tratados internacionais de direitos humanos ratificados pelo Brasil. No entanto, até hoje o Brasil não permite o pleno exercício de direitos aos estrangeiros residentes.

O desafio é descobrir qual o desenho de nosso ordenamento jurídico para a questão dos estrangeiros. Nesse contexto, as questões que se colocam evidenciam uma forte tensão entre os limites da soberania estatal e a ampla liberdade e igualdade de direitos preconizada pelos tratados internacionais. A cidadania é o elemento de distinção relevante entre os direitos garantidos aos estrangeiros e aos nacionais.

As perspectivas revelam que a maior dificuldade no tratamento digno e igualitário do estrangeiro é o apego ao critério da cidadania e o fato de que a matéria é

185 Yussef Said Cahali, Estatuto do Estrangeiro, p. 73.

186 Disponível em: <http://www.planalto.gov.br/ccivil_03/Constituicao/constituicao67.htm>. Acesso em 02.01.2013. 
considerada doméstica, submetendo-se à soberania dos Estados para definir suas políticas relacionadas à abertura ou fechamento de suas fronteiras para o ingresso de estrangeiros.

O Brasil tem demonstrado interesse em reformular e modernizar sua política migratória de modo a harmonizá-la com os direitos humanos dos migrantes. Exemplo disso foi a promulgação da chamada "Lei da Anistia Migratória", Lei n. 11.961, de 02.07.2009,

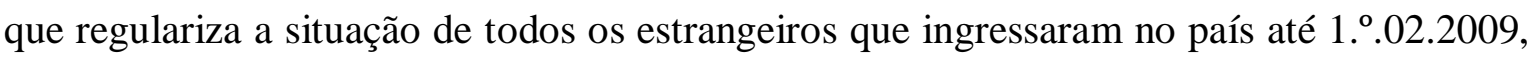
assegurando aos que estão em situação migratória irregular o direito de requerer a residência provisória. ${ }^{187}$

Entretanto, a cidadania, tal como a compreendemos atualmente no Brasil, ainda é restrita, como se extrai do texto do art. $1 .^{\circ}$, inciso III, da Constituição Federal do Brasil de 1988, na parte em que assegura aos nacionais, dentro de um determinado Estado, exercer direitos políticos, econômicos, sociais e culturais destinados ao indivíduo enquanto cidadão deste Estado.

A característica essencial da cidadania brasileira é o ato de pertencer a uma nação, de viver sob o domínio do poder soberano de um Estado. Como se vê, essa dimensão da cidadania, essa faceta de tratamento diferenciado do estrangeiro, atravessou os séculos e se reproduziu generalizadamente pelo mundo afora.

Amaral Júnior esclarece que, embora a nacionalidade e a cidadania sejam expressões utilizadas comumente com a mesma acepção, não devem ser confundidas: a nacionalidade identifica o elo entre o indivíduo e o Estado, enquanto a cidadania abrange os direitos políticos reconhecidos aos indivíduos. ${ }^{188}$

Nossa Constituição sinaliza uma dificuldade enorme de diálogo entre as jurisdições. Com efeito, por força da organização de nosso sistema em pirâmide, na linha da teoria de Kelsen, não há praticamente nenhuma porosidade que nos permita certa permeabilidade no diálogo entre os poderes públicos envolvidos com essa temática do trabalho internacional.

\footnotetext{
187 Íntegra da lei da anistia migratória disponível em: <http://www.planalto.gov.brlccivil_03\Ato20072010|2009LLeilL11961.htm>. Acesso em: 6 out. 2013.

188 Alberto do Amaral Júnior, Introdução ao direito internacional público, p. 323.
} 


\subsection{Nacionalidade brasileira}

A nacionalidade é adquirida sob diversos critérios. O nascimento em determinado Estado em geral confere o direito à nacionalidade ordinária, pelo critério do ius soli (local do nascimento). Amaral Júnior destaca que o ius soli foi a estratégia adotada por países desejosos de integrar os filhos dos estrangeiros à nação na qual estes nasceram, evitando assim a formação de novas comunidades e promover a integração plena ao país. $^{189}$

O mesmo autor destaca que o oposto ocorre quando o Estado adota o ius sanguinis, conferindo aos filhos direito à mesma nacionalidade dos pais ou antepassados até determinado grau. O ius sanguinis foi utilizado nos dois últimos séculos por países europeus com intuito de preservar o vínculo entre o Estado de origem e os filhos de uma parcela expressiva da população que migrava para o continente americano.

A condição de estrangeiro, no dizer de Rodrigo Octavio, citado por Yussef Said Cahali, é definida pela via da oposição ao nacional. Portanto, nacionais são os indivíduos que assim são reconhecidos pelas leis de um Estado. Por exclusão, estrangeiros são todos os demais indivíduos que vivem no território deste mesmo Estado, mas não foram contemplados na definição de cidadão. ${ }^{190}$

$\mathrm{O}$ ingresso pelos canais regulares coloca o migrante ao albergue da Constituição Federal, que no art. . $^{\text {o }}$, incisos III e IV, destaca os princípios da dignidade da pessoa humana e os valores sociais do trabalho e da livre-iniciativa.

Dentre os objetivos fundamentais, o art. 3..$^{\circ}$ aponta a construção de uma sociedade livre, justa e solidária, a promoção do bem de todos, sem preconceitos de origem, raça, sexo, cor, idade e quaisquer outras formas de discriminação.

Mais adiante, o caput do art. 5. ${ }^{\circ}$ dispõe sobre a igualdade de todos perante a lei, sem distinção de qualquer natureza, garantindo aos brasileiros e aos estrangeiros residentes no País a inviolabilidade do direito à vida, à igualdade, à segurança e à propriedade.

\footnotetext{
189 Alberto do Amaral Júnior, Introdução ao direito internacional público, p. 326.

190 Yussef Said Cahali, Estatuto do Estrangeiro, p. 26; Rodrigo Octavio, Direito do estrangeiro no Brasil.
} 
Especificamente quanto ao trabalho, o inciso XIII do art. $5^{\circ}$ garante ao trabalhador migrante o exercício de qualquer trabalho, ofício ou profissão, desde que preenchidos os requisitos da legislação pertinente, à exceção dos cargos privativos de brasileiros natos, conforme dispõe o art. $12, \S 3 .^{\circ}$, da CF.

Contudo, como lembra Lopes, é restrita a acessibilidade do estrangeiro a cargos públicos, na medida em que o art. 14, § 2. ${ }^{\circ}$, vincula a futura previsão legal. Ressalta, ainda, a vedação expressa de acesso a cargos de Presidente e Vice-Presidente da República, presidente da Câmara dos Deputados, presidente do Senado Federal, de Ministro do Supremo Tribunal Federal, da carreira diplomática, de oficial das Forças Armadas e de Ministro de Estado da Defesa. ${ }^{191}$

A concessão do visto configura uma expectativa de direito, pois se constitui em exercício do poder soberano do Estado, de modo que poderá ser denegada por variados motivos, quando se tratar de pessoa nociva à ordem pública, se já tiver ocorrido a sua expulsão do país ou quando tiver sido condenada ou processada em outro país por crime doloso.

\subsection{Teorias sobre os fluxos migratórios de e para o Brasil}

\subsubsection{Tipologia dos fluxos migratórios para o Brasil}

Diferente da tipologia da migração a trabalho apresentada no capítulo anterior, o Brasil ainda vive uma realidade muito distinta da dos países considerados desenvolvidos que, desde o fim da Segunda Guerra Mundial, necessitam suprir parte de seus postos de trabalho com a força de trabalho dos migrantes.

O movimento de migrantes para o Brasil, de acordo com o Censo Demográfico de 2010, era representado por apenas 431.453 estrangeiros. Contudo, essa informação não

191 Cristiane Maria Sbalqueiro Lopes, Direito de imigração: o Estatuto do Estrangeiro em uma perspectiva de direitos humanos, p. 459. 
levava em conta, como adverte a pesquisadora Marden Barbosa de Campos, os migrantes em situação irregular. ${ }^{192}$

O fluxo de migração para o Brasil é identificado por estudiosos com uma tipologia que abrange: a migração internacional do trabalhador global qualificado, a migração internacional de grupos étnicos e a migração internacional fronteiriça. ${ }^{193}$

Desde 2009, com a vigência do Acordo de Residência do Mercosul, os migrantes nacionais dos países do Mercosul, além da Bolívia, do Chile, do Peru e da Colômbia, são titulares do direito de requerem autorização para residirem provisoriamente no Brasil. Contudo, não há dados que permitam identificar quantos migrantes regularizaram a situação de permanência no país sob esse Acordo.

Segundo estatísticas do Conselho Nacional de Imigração, os Estados Unidos lideraram a lista de países de origem dos trabalhadores estrangeiros que chegaram ao Brasil em 2007: foram 4.519, quase o dobro do segundo colocado, Reino Unido, com 2.474 pessoas. Em terceiro, as Filipinas, com 2.120 autorizações concedidas.

Muitos desses estrangeiros vêm ao Brasil por conta de outro fenômeno do crescimento da economia: a importação de equipamentos.

De acordo com o presidente do Conselho Nacional de Imigração e coordenador-geral de Imigração do Ministério do Trabalho e Emprego, Paulo Sérgio de Almeida, a importação necessita de pessoas que saibam operar essas máquinas e, por isso, as empresas também "importam" técnicos dos países de origem para lidar com essa tecnologia, ainda que temporariamente. ${ }^{194}$

A maior parte dos migrantes que vivem no Brasil provém de Portugal, Itália, Espanha, Bolívia, Argentina, Paraguai e Uruguai, refletindo um fluxo natural em razão dos laços históricos que ligam, por exemplo, Brasil e Portugal, além do papel relevante da

192 Marden Barbosa Campos. Reversão do saldo migratório internacional negativo do Brasil? Evidências preliminares com base nos dados do censo 2010, p. 185.

193 Rosana Baeninger, Populações e políticas sociais no Brasil: os desafios da transição demográfica e das migrações internacionais, p. 254.

194 Disponível em: <http://porta.mte.gov.br|gerallestatisticas.htm>. Acesso em: 8 out. 2013 
Itália, Alemanha e Japão, de onde vieram as levas populacionais que colonizaram o país no século XIX e início do século XX. ${ }^{195}$

Foi detectado, ainda, um aumento relacionado ao crescimento econômico brasileiro e à realização das obras para a Copa do Mundo de 2014 e as Olimpíadas de 2016, conforme dados do Ministério do Trabalho e Emprego, que apontam para a elevação do número anual em torno de 30.000 autorizações de trabalho entre 2009 a $2011 .{ }^{196}$

\subsubsection{Inserção dos imigrantes no mercado de trabalho brasileiro}

Apesar da existência de várias teorias que buscam explicar como se dá a inserção do migrante no mercado brasileiro, não há um consenso sobre os fatores que determinam a igualdade de oportunidades e de níveis salariais entre brasileiros e migrantes.

Becker, dentre outros, destaca a "educação e a experiência" como determinantes para explicar o maior ou menor nível de salários dos trabalhadores migrantes, contudo a doutrina de Vilela aponta a "origem" como um dos fatores mais relevantes para o menor ou maior grau de inserção dos trabalhadores migrantes no mercado de trabalho brasileiro. ${ }^{197}$

Para os propósitos do presente estudo, combinamos o estudo de Vilela, Baeninger, Cogo e Banet, nos quais nos baseamos, para estabelecer a seguinte tipologia:

\section{- Trabalhador global}

A migração internacional do trabalhador global compõe no Brasil uma fatia significativa dos movimentos migratórios, beneficiando-se, como aponta Baeninger, da reestruturação produtiva e do consequente processo de globalização do País, tratando-se de profissionais altamente qualificados. No âmbito corporativo, esses profissionais são comumente identificados como "expatriados".

195 Disponível em: <http://fgv.projetos.fgv.brlsiteslfgv.brlfileslfgv_dapp_imigração>. Acesso em: 21 set. 2013.

196 Disponível em: <http://www.mte.gov.brlbase estatística>. Acesso em: 30 jun. 2012.

197 Gary S. Becker, Human capital: a theoretical and empirical analysis, with special reference to education, p. 20-31. 


\section{- Migrações no âmbito do Mercosul}

Como resultado da inserção do Brasil no Mercosul, movimentos migratórios intrarregionais se intensificaram a partir de 1980, destacando-se a seguinte tipologia classificada por Cogo e Banet: ${ }^{198}$

i. Modalidades de tipo fronteiriço: o movimento de circulação de trabalhadores entre os países do Mercosul

ii. Migrações em direção às áreas metropolitanas: caracterizado sobretudo pelo movimento de bolivianos e peruanos.

iii. Migrações intrarregionais com países não limítrofes: como é o caso dos chilenos.

No âmbito da migração fronteiriça, o caso envolve o Mercosul, e os fluxos foram identificados particularmente da Argentina para o Brasil, com indivíduos de nível superior e pós-graduação.

Trata-se, como define Baeninger, "de um tipo sui generes, especial, de trabalhador que vive na região de fronteira de seu país e trabalha na região de fronteira do país vizinho e retorna à sua residência, diariamente ou no fim de semana, não se tratando de processo migratório definitivo ou mesmo temporário. ${ }^{199}$

A migração internacional transfronteiriça se intensificou a partir da década de 90 em Foz do Iguaçu e Santana do Livramento, e envolve indivíduos de escolaridade mais baixa, como o caso dos paraguaios, que respondem por cerca de $11 \%$ do fluxo dessa categoria de migrantes. Os migrantes uruguaios, chilenos e bolivianos correspondem a cerca de $3 \%$ do fluxo migratório e o Peru, apenas $7 \%$.

198 Denise Maria Cogo e Maria Badet Souza, Guia das migrações transnacionais e diversidade cultural para comunicadores - migrantes no Brasil. Disponível em: 〈http://www.guiamigracoesdivcult.com>. Acesso em: 29 set. 2013.

199 Rosana Baeninger, Populações e políticas sociais no Brasil: os desafios da transição demográfica e das migrações internacionais, p. 257. 
Vilela buscou comparar determinados grupos de migrantes e brasileiros. Embora o trabalho da autora esteja restrito justamente pela falta de estatísticas oficiais sobre a inserção de migrantes no mercado de trabalho brasileiro, ele permite uma visão mais aprofundada sobre essa importante característica do migrante. ${ }^{200}$

\section{- Comparativo entre brasileiros $x$ uruguaios, paraguaios e bolivianos}

Com amparo nas modernas teorias de estratificação do mercado de trabalho, a origem se revelou, mais do que a nacionalidade, como um fator determinante para a inserção dos imigrantes no mercado de trabalho brasileiro. No comparativo entre migrantes e brasileiros, Vilela aponta que, em geral, os uruguaios, paraguaios e bolivianos são mais suscetíveis de ser submetidos a rendimentos piores do que os brasileiros, destacando que, no caso específico dos uruguaios, essa hipótese foi confirmada entre os uruguaios, mas não chegou a revelar que todos os paraguaios e bolivianos recebem salários inferiores.

\section{- Comparativo entre brasileiros $x$ asiáticos (coreanos e chineses)}

Segundo a mesma pesquisa, o grupo dos migrantes de origem asiática está em condição de vantagem nas condições de inserção e de rendimentos no mercado brasileiro.

\section{- Comparativo entre brasileiros e migrantes com curso superior}

Apesar da origem se constituir em importante fator para a inserção do migrante no mercado de trabalho brasileiro, as pesquisas consultadas denotam que as variáveis relacionadas ao capital cultural e social determinam uma melhor inserção dos migrantes.

Ao contrapormos essas abordagens sobre a tipologia atual da migração a trabalho para o Brasil, verificamos que a legislação de ingresso do migrante no Brasil nem de longe contempla essa diversidade de fenômenos.

Inexiste, por exemplo, um visto de ingresso específico para abranger os migrantes de baixa escolaridade. Para esses indivíduos, a via única será o Acordo de

200 Elaine Meire Vilela, Imigração internacional e estratificação no mercado de trabalho brasileiro. Disponível em: <http://www.bibliotecadigital.ufmg.br/dspace/bitstream/handle/1843/VCSA874kj4.pdf>. Acesso em: 30 set. 2013. 
Residência do Mercosul, em vigor desde 2009, mas restrito aos cinco países do Mercosul (Argentina, Brasil, Uruguai, Paraguai e Venezuela), além da Bolívia e do Chile. ${ }^{201}$

\subsubsection{Inserção dos emigrantes no mercado de trabalho estrangeiro}

O número de emigrantes no Brasil ainda supera o de imigrantes no País, que assistiu a uma redução progressiva da migração estrangeira na década de 90, enquanto os fluxos emigratórios internacionais aumentaram e se diversificaram. Carvalho aponta que na década de 80 os emigrantes brasileiros somavam pouco mais de 1.038 .000 pessoas, número que aumentou para cerca de 1.800 .000 na década de $90 .^{202}$

Brasileiros são encontrados em praticamente em todas as partes do mundo, a despeito de estritas restrições por parte de países com políticas migratórias mais fechadas à migração. Na década de 1980, algumas análises associavam a saída de brasileiros com o que convencionou chamar de "a década perdida", ou a "conjuntura Collor", contudo Patarra e Baeninger estabelecem uma correspondência do fenômeno ao natural desejo de participar de uma nova etapa econômica que se delineava com a globalização da economia. $^{203}$

Em 1990, os fluxos migratórios dos brasileiros se tornaram mais constantes, em direção aos países ricos. A saída foi decorrente das transformações na "dinâmica recente do capitalismo, caracterizada pela globalização da produção, que se apoia na flexibilidade dos processos de trabalho, dos mercados de trabalho, dos produtos e dos padrões de consumo". 204

Em 2010, a estimativa de brasileiros residindo no exterior era de 3,1 milhões de pessoas. Esse contingente se distribuiu da seguinte forma: 1,4 milhão na América do

201 Disponível em: <http//www.planalto.gov.br/ccvil_03/_Ato2007-2010/2009/Decreto/D6975.htm>. Acesso em: 30 set. 2013.

202 José Alberto M. Carvalho, Migrações internacionais do Brasil nas duas últimas décadas do século 20: algumas facetas de um processo complexo, amplamente desconhecido. Texto apresentado no encontro sobre Remessas, Previdência Social e Políticas Públicas, Brasília, 2004.

203 Neide Lopes Patarra, Migrações internacionais de e para o Brasil contemporâneo. Volumes, fluxos, significados e políticas, p. 23-33.

204 Rosana Baeninger, Migrações internacionais recentes: o caso do Brasil, p. 70. 
Norte; 400 mil na América do Sul; 6,8 mil na América Central; 912 mil na Europa; 29 mil na África e 53 mil na Oceania. ${ }^{205}$

\section{- Fluxos para o Hemisfério Norte}

Segundo Ushijima, os setores de serviços continuam a influenciar o destino dos brasileiros migrantes, sendo possível perceber uma concentração de maior fluxo nos países do Hemisfério Norte, por serem sede de grandes empresas transnacionais, centros financeiros.

No entanto, uma vez lá, é comum os migrantes, independentemente da qualificação e escolaridade, ocuparem postos denominados de secundários, em virtude da escassez de mão de obra nacional e de um estigma cultural que faz com que nativos apresentem uma resistência ao trabalho em clínicas, restaurantes, lavanderias, táxis, serviços de engraxates. ${ }^{206}$

Nesse ponto, Portes destaca que historicamente essas ocupações eram destinadas a migrantes sem perspectivas de ascensão, com baixa qualificação e por isso mal remunerados. ${ }^{207}$

\section{- Fluxos para os Estados Unidos}

O fluxo de brasileiros para os Estados unidos foi estimado em 2011 como algo em torno de 1,4 milhão. ${ }^{208}$ De acordo com Lima, São brasileiros naturais de Minas Gerais, Goiás, São Paulo, Paraná e Santa Catarina que normalmente se concentram nos Estados americanos da Flórida, Massachusetts, Califórnia, Nova York, Nova Jersey, Connecticut, Texas, Geórgia, Maryland, Illinois e Pensilvânia. ${ }^{209}$

205 Dados extraídos da compilação de dados do Ministério das Relações Exteriores 2009 - 2001. Disponível em: 〈http://www.culturaacademica.com.br \_imglarquivos_externa_brasileira-WEB.pdf>. Acesso em: 2 out. 2013.

206 Fernanda Rais Ushijima, A política externa brasileira para os emigrantes e seus descendentes, p. 38.

207 A. Portes, Introduction: the debate and significance of immigrant and transnationalism, p. 59-61.

208 Disponível em: <http://www.mre.gov.br/estatisticas_2011.htm>. Acesso em: 4 set. 2013.

209 A. Lima, Brasileiros na América, p. 28-30. 
O grau de escolaridade dos brasileiros é considerado por Lima como relativamente alto em relação à população nativa e, sobretudo, quando comparados aos demais imigrantes, o que os possibilita, quando migrantes regularizados, almejar postos mais elevados do que as posições secundárias que mencionamos anteriormente.

O país é o que mais recebe migrantes, apesar de possuir políticas migratórias bem restritivas, conforme demonstramos no Capítulo 2, que, segundo Marinucci, resulta em que cerca de $64 \%$ da população de migrantes brasileiros seja considerada administrativamente irregular no País. ${ }^{210}$

\section{- Fluxos para a Europa}

O interesse dos brasileiros pela Europa tem aumentado significativamente, inclusive superando o fluxo para os Estados Unidos, situação que Gradilone entende decorrer das rígidas mudanças nas políticas migratórias dos Estados Unidos após os atentados de 11 de setembro de $2001 .^{211}$

Em 2010, o número de brasileiros atingiu os seguintes patamares: 180 mil no Reino Unido; 159 mil na Espanha; 136 mil em Portugal; 91 mil na Alemanha; e 85 mil na Itália. $^{212}$

Em alguns casos, o que contribui para a opção de migrar para a Europa é a ascendência europeia, pois muitos brasileiros possuem dupla cidadania, como destaca Patarra. ${ }^{213}$ As características dos brasileiros na Europa não diferem dos que migram para os Estados Unidos, e, em geral, se caracterizam pela preferência pelos centros urbanos, e,

210 R. Marinucci, Brasileiros e brasileiras no exterior: apresentação de dados recentes do Ministério das Relações Exteriores. Disponível em: <http://www.csem.org.br\2008\roberto_marinucci_brasileiros_e_brasileiras_no_exteriorsegundo_dados_ do_mre_junho2008.pdf>. Acesso em: 20 jun. 2013.

211 E. Gradilone. Proposta de política governamental para comunidades brasileiras no exterior, brasileiros no mundo. I. Rio de Janeiro, Anais eletrônicos..., Brasília: Ministério das Relações Exteriores, SubscretariaGeral das Comunidades brasileiras no exterior, 2008. Disponível em: 〈http://www.abe.mre.gov.br>. Acesso em: 18 out. 2010.

212 Ministério das Relações Exteriores, data-base 2010.

213 Neide Lopes Patarra, Migrações internacionais de e para o Brasil contemporâneo. Volumes, fluxos, significados e políticas, p. 211. 
quando em situação regular, podem ascender a ocupações de maior remuneração, pois em geral possuem maior grau de instrução relativo.

\section{- Fluxos para o Japão}

A migração de brasileiros para o Japão está diretamente relacionada à etnia e às influências culturais nipônicas. Sasaki identifica o final da década de 1980 e início de 1990 como um período de maior fluxo de brasileiros ao Japão, em razão da lei japonesa de Controle de Imigração, que oficializou a preferência pela migração de descendentes de japoneses - caracterizando a massificação do movimento dekassegui de brasileiros.

Entretanto, esse movimento se inverteu em 2009 quando a crise econômica, somada à diminuição de familiaridade dos migrantes mais recentes com a cultura e a língua, acentuou problemas antigos. ${ }^{214}$

Ainda há cerca de 210 mil brasileiros no Japão, dos quais, de acordo com Ninomiya, a maioria está concentrada nas províncias de Aichi, Shizouka, Mie, Gifu e Shiga, localidades que reúnem indústrias automobilísticas e eletroeletrônicas japonesas. Um fato curioso, relatado por Ninomiya, é o crescente número de ações cíveis movidas contra brasileiros residentes no Japão, relacionadas a pensão alimentícia e divórcio. Segundo o autor, é comum os decasséguis constituírem novas famílias no país, abandonando seus familiares no Brasil, sem recursos para o sustento. ${ }^{215}$

\section{- Fluxos para o Paraguai}

O fluxo de brasileiros para o Paraguai se intensificou a partir de 1970, época em que Ushijima destaca as medidas governamentais destinadas a ofertas de terra a preços baixos, incentivos agrícolas, em atenção ao objetivo do General Stroessner de desenvolver

214 Eliane Sasaki, A imigração para o Japão. Disponível em <http://scielo.br/scielo.php? script=arttex\&pid=S0103-401420060002000009\&ing>. Acesso em: 5 set. 2013.

215 Masato Ninomiya, em entrevista concedida ao jornalista Elton Alisson, de Tóquio em 19.03.2013.

Disponível em 〈http://agencia.fapesp.br/16988>. Acesso em 29 set. 2013. 
a fronteira oriental, de baixa densidade populacional, política que atraiu brasileiros interessados em adquirir propriedades e desenvolver atividades de agricultora. ${ }^{216}$

No entanto, a presença de um número considerável de pessoas em situação irregular no Paraguai, além da crítica social à legitimidade da expansão agrícola, resultou em uma relação conflituosa, com vários incidentes no campo, incluindo queima de plantação e frutos de casas de brasileiros.

\subsection{Lei de Migrações para o Brasil}

\subsubsection{Lei n. 6.815/1980 - Estatuto do Estrangeiro}

A entrada e a permanência do estrangeiro no Brasil é regulada pela Lei n 6.815, de 19.08.1980 - Estatuto do Estrangeiro - que, conquanto reconheça, em seu art. 1. ${ }^{\circ}$ o direito de qualquer estrangeiro entrar e permanecer no Brasil e dele sair, alinhando-se assim à Declaração dos Direitos do Homem, que enuncia idêntico direito de ir e vir em seu art. XIII, n. 2, logo adiante, no art. 2. ${ }^{\circ}$, a lei do estrangeiro enfatiza que a lei atenderá precipuamente à segurança nacional, à organização institucional, aos interesses políticos, socioeconômicos e culturais do Brasil e, bem assim, à defesa do trabalhador nacional.

O Estatuto foi concebido durante a chamada "década perdida" em que o Brasil já não era mais o destino de fluxos relevantes de migrantes europeus. $\mathrm{Na}$ verdade, a promulgação do Estatuto coincide com uma época de aumento do número de migração clandestina incentivada pelas instabilidades sul-americanas e que abrangia imigrantes ilegais ainda sem o amparo do Acordo de Residência do Mercosul, que só se efetivou em 2009.

Assim, a concessão do visto, a prorrogação ou a transformação, nas disposições do art. $3^{\circ}$, de inspiração autoritária, ficam condicionadas aos interesses nacionais. Adverte Yussef Said Cahali que, apesar de as "razões de solidariedade universal, de justiça, de humanidade" apontarem o vetor em prol da admissão dos estrangeiros, a lei de estrangeiros

216 Fernanda Rais Ushijima, A política externa brasileira para os emigrantes e seus descendentes, p. 48. 
brasileira se lança como competente para determinar as condições de admissibilidade do estrangeiro. $^{217}$

As disposições iniciais da Lei n. 6.815 demonstram claramente o intuito de preservar os interesses nacionais, na aplicação da lei na execução das políticas migratórias e na defesa do trabalhador nacional, a começar pelo texto do art. $2 .^{\circ}$, de seguinte teor:

Art. 2. ${ }^{\circ} \mathrm{Na}$ aplicação desta Lei atender-se-á precipuamente à segurança nacional, à organização institucional, aos interesses políticos, socioeconômicos e culturais do Brasil, bem assim à defesa do trabalhador nacional.

Portanto, o ingresso e a permanência de qualquer estrangeiro no Brasil se colocam efetivamente como uma "mera expectativa de direito", inequivocamente atrelado à soberania do País e à competência deste para determinar as condições de seu ingresso e permanência, segundo consta expressamente do art. 26 da Lei, ao dispor que:

O visto concedido pela autoridade consular configura mera expectativa de direito, podendo a entrada, a estada ou o registro do estrangeiro ser obstado, ocorrendo qualquer dos casos do art. $7 .^{\circ}$, ou a inconveniência de sua presença no território nacional, a critério do Ministério da Justiça.

A partir da promulgação do Estatuto de 1980, o Brasil nitidamente adota uma política extremamente restritiva, em que o migrante só poderá ingressar no País sob uma condição provisória, ao patrocínio de empresa instalada no País (exceção ao investidor estrangeiro), e desde que essa empresa chamante comprove que o migrante possui conhecimento especializado técnico, acadêmico e experiência profissional e a ausência de indícios de que o estrangeiro substituirá um trabalhado nacional.

Em 1981, o Congresso Nacional editou a Lei n. 6.964, que objetivou amenizar aspectos considerados excessivamente autoritários. No entanto, a iniciativa mais relevante no sentido de substituir o Estatuto ocorreu com o Projeto de Lei n. 1.813, de 21.10.1991, por disposição do Ministério da Justiça, redigido em consonância com a nova Constituição Federal de 1988 , e que objetivava, em seus arts. $2 .^{\circ}$ e $3 .^{\circ}$, introduzir novos objetivos na

217 Yussef Said Cahali, Estatuto do Estrangeiro, p. 72. 
aplicação das leis migratórias, de modo a atender, além dos interesses nacionais e da proteção do trabalhador brasileiro, a cooperação internacional nas áreas de educação e tecnologia e a solidariedade internacional. O projeto de toda forma era bastante similar ao Estatuto existente e atraiu várias críticas da sociedade civil e das comissões do Congresso Nacional, tendo sido arquivado depois de aproximadamente dez anos de tramitação.

Em que pese o reconhecimento de que alguns dispositivos do Estatuto atual colidem com a atual Constituição e por isso restariam revogados, ainda que não expressamente, é relevante notar que o critério da nacionalidade (exigência da proporção de 2/3 de brasileiros para 1 estrangeiro) continua sendo aplicada na prática por deliberação do Conselho Nacional de Imigração (CNIg).

\subsubsection{Projeto de Lei n. 5.655/2009}

Em 2009, o Projeto de Lei n. 5.655/2009, ${ }^{218}$ de autoria do Poder Executivo, deveria modificar a vetusta Lei n. 6.815, com intuito de fortalecer as relações com os estrangeiros no Brasil e com os brasileiros no exterior, mediante uma legislação voltada a regular a situação dos imigrantes e dos emigrantes.

Em sua proposta, o projeto defende uma visão positiva para a migração e o desenvolvimento econômico, porém a nova mantém em sua essência o paradigma da segurança nacional e se contrapõe à política nacional de imigração e proteção ao trabalhador migrante, aprovada pelo Conselho Nacional de Imigração, desde meados de 2010.

As opiniões sobre o PL 5.655 se dividem.

Representantes da Força Sindical consideram que os migrantes poderão "tirar os bons empregos dos brasileiros", e cobram maior fiscalização do Ministério do Trabalho, com o intuito de permitir apenas a estadia durante períodos curtos, suficientes para a montagem de uma empresa, evitando-se, assim, que o migrante permaneça no país por tempo indeterminado e concorra com os brasileiros pelas melhores vagas.

218 Disponível em: <http://www.camara.gov.br/proposicoesWeb/fichadetramitacao?idProposicao= 443102〉. Acesso em: 2 out. 2013. 
Representantes da Comissão de Relações Exteriores e de Defesa Nacional da Câmara ponderam que

[...] há empregos para aqueles que têm mestrado e doutorado e há também postos para pessoas mais simples. Nosso povo foi formado a partir de imigrantes de vários continentes e temos de receber todos de braços abertos, qualquer posição de cerceamento dessa vinda xenófoba. ${ }^{219}$

De fato, é relevante lembrar que o Brasil deve a sua formação à contribuição de imigrantes de toda parte, revelando-se no mínimo incoerente a restrição ao ingresso de estrangeiros no país. Ademais, o país ainda não convive com um fluxo significativo de migrantes, se comparado à nossa população de aproximadamente 191 milhões de habitantes, para que se possa justificar o uso de medidas restritivas e seletivas.

Retomando as possíveis causas da morosidade na reforma do Estatuto do Estrangeiro encontramos na obra de Coentro, a menção à falta de mobilização de esforços em prol da migração, como consequência dos "limitados direitos políticos dos migrantes (tanto emigrantes como imigrantes), que não os permitem eleger representantes no Legislativo para fazer valer a democrática e objetivamente seus interesses". 220

E, finalmente, há divergências de entendimento sobre o tratamento a ser dado à migração. Não podemos esquecer que os projetos de lei enviados ao Legislativo em 1991 e 2009 foram iniciativas do Ministério da Justiça, que nem sempre se alinham às posições do CNIg, órgão do Ministério do Trabalho e Emprego, que, por sua vez, também poderá colidir com o entendimento da Casa Civil e de outros membros do Legislativo.

O PL n. 5.655 avança timidamente nas questões de direitos dos migrantes. Conforme se observa do art. $4 .^{\circ}$, a política imigratória objetivaria primordialmente a admissão de mão de obra especializada e adequada aos vários setores da economia nacional, ao desenvolvimento econômico, social, cultural, científico e tecnológico do Brasil, à captação de recursos e geração de emprego e renda.

\footnotetext{
219 Disponível em: <http://www2.camara.leg.br/camaranoticias/noticias/RELACOESEXTERIORES/434769>. Acesso em: 2 out. 2013. A posição que citamos contra é de autoria de Paulo Sérgio de Almeida; posição contra o projeto é de autoria do Deputado Carlos Alberto Leréia.

220 Luciana Unis Coentro, Políticas públicas e gestão das migrações internacionais do Brasil: uma reflexão sobre os migrantes qualificados, p. 124-125.
} 
O Projeto está dividido em nove títulos e possui 160 artigos, que objetivam disciplinar temas como: a) uma política nacional de migração que ofereça proteção e regulamente a imigração e a emigração; b) os direitos, deveres e garantias do estrangeiro; c) os documentos de viagem, vistos, residência e condição de asilo; d) entrada, registro e saída de estrangeiros; e) naturalização, repatriação, deportação, expulsão e extradição; f) infrações e respectivas sanções; e g) a transformação do Conselho Nacional de Imigração em Conselho Nacional de Migração.

Para Póvoa Neto e Sprandel, a nova lei que tramita no Congresso desde julho de 2009 é um esforço para que o Brasil possa adequar-se à realidade migratória atual, pois a proposta trata a migração como um direito do homem e objetiva a inserção do migrante na sociedade. ${ }^{221}$

A proposta evolui em alguns aspectos, porém ainda há um ranço de restrição a direitos:

i. Quanto ao visto de trabalho, o Projeto inova e facilita o ingresso de trabalhador migrante sem vínculo empregatício, por um prazo de até um ano, contudo ainda vincula à comprovação de "necessidade do trabalho de estrangeiro no Brasil, conforme disposto em regulamento" (art. 26);

ii. O trabalhador migrante com vínculo empregatício continua sob a condição de temporário e impedido de mudar de empregador, e, em caso de alterações na empresa chamante, o trabalhador necessitará de manifestação do Ministério do Trabalho e Emprego, em caso de mudança de empregador por conta de fusão, incorporação, transformação ou agrupamento empresarial, assim como continuam vedadas quaisquer alterações no contrato (art. 29, inciso $1 .^{\circ}$ );

iii. Um avanço se refere à possibilidade de concessão de visto permanente para o migrante que comprovar notório conhecimento em sua área de atuação profissional (art. 34, III);

221 Helion Póvoa Neto e Marcia A. Brasil Sprandel, Os objetivos da Conferência Internacional sobre População e Desenvolvimento (Cairo, 1994) e a política migratória brasileira, p. 317. 
iv. Não há direito de voto ao estrangeiro, o que de certo modo se justifica ante a restrição que a própria Constituição coloca em relação à participação política do estrangeiro, logo essa barreira exigiria a reformulação da Constituição Federal;

v. O processo de naturalização será ainda mais difícil. A lei atual exige residência no Brasil pelo prazo mínimo de quatro anos (art. 112, III). O PL aumenta o prazo mínimo para dez anos (art. 87, III);

vi. Quanto ao visto permanente por casamento, a lei atual o concede temporário para estrangeiros que se casam com brasileiros. $\mathrm{O}$ visto permanente ao cônjuge estrangeiro só após cinco anos de casamento.

Do ponto de vista do direito, a temática da migração internacional para o Brasil foi pontuada por alguns avanços, revelando-se que o direito atuou positivamente para o incremento de medidas visando à redução das desigualdades que permeiam a mobilidade internacional.

Muitos desafios ainda se apresentam e decorrem das deficiências dos sistemas políticos de todos os países em vislumbrar um arranjo institucional alinhado com os instrumentos internacionais que reconhecem um amplo conjunto de liberdades e direitos aos estrangeiros, dificilmente implementado por meio de políticas públicas nos sistemas nacionais.

Há dificuldades na concretização da efetivação dos direitos fundamentais e a redução da desigualdade. É verdade que temos de reconhecer que a constitucionalização de direito voltados à proteção dos estrangeiros diretamente na constituição, sobretudo no que concerne à igualdade de tratamento, é um caminho importante para a eficácia, porém a própria Constituição, como vimos, ainda contém certas restrições, como a prevenção ao pleno exercício de direitos políticos que denunciam que ainda temos "um pé" no retrocesso. Continuamos como um país que discrimina os estrangeiros, sendo o exemplo mais gritante as restrições que ainda perduram no atual Estatuto do Estrangeiro, e não nos parece que a nova lei se dispôs a abrandar tais restrições. 
Outras propostas resultaram dos diálogos tripartites realizados sobre políticas públicas de migração para o trabalho, sendo relevante destacar o trabalho publicado pela OIT, em 2009, no qual são apresentadas contribuições para a promoção do trabalho decente na agenda das políticas migratórias a trabalho, destacando-se fenômenos como a migração e grupos étnicos, o tráfico de pessoas e a situação irregular dos bolivianos na cidade de São Paulo. ${ }^{222}$

\subsubsection{Nova proposta - Ministério da Justiça e Comissão de Especialistas}

A título de fechamento de nossa análise sobre a lei de migração atual e vindoura, é importante mencionar que uma nova proposta de Anteprojeto de lei de migrações e promoção dos direitos dos migrantes no Brasil está sendo estudada por uma comissão de especialistas nomeados pelo Ministério da Justiça, criada pela Portaria MJ n. 2.162, integrada pelos professores: André de Carvalho Ramos, Aurélio Veiga Rios; Clèmerson Merlin Clève; Deisy de Freitas Lima Ventura; José Luis Bolzan de Morais; Pedro de Abreu Dallari; Rossana Rocha Reis; Tarcíso dal Maso Jardim; e Vanessa Oliveira Berner.

A necessidade de assegurar um projeto justo para a situação irregular de estrangeiros torna mais do que bem-vinda a formação dessa comissão de notáveis, e ficamos todos na expectativa da conclusão dos trabalhos, com data prevista para o ano de 2013.

Até o momento da conclusão do presente trabalho, não havia sido disponibilizado o resultado dos estudos da referida comissão.

${ }^{222}$ André Luis Borges de Mattos e Guilherme Mansur Dias (Org.), Trabalhadores migrantes e trabalho decente no Brasil. 


\subsection{Sistema atual de gestão das políticas migratórias}

\subsection{1 Órgãos e competências}

No Brasil, a gestão e o monitoramento das políticas migratórias são distribuídos entre os seguintes órgãos: Ministério da Justiça, Ministério do Trabalho e Emprego, Receita Federal, Previdência Social e Ministério das Relações Exteriores e Polícia Federal, além do Ministério da Ciência e Tecnologia, Ministério da Educação e Ministério do Desenvolvimento, Indústria e Comércio. Podemos ainda inserir a atuação do Ministério Público do Trabalho que muito tem contribuído para lançar luzes sobre os migrantes indocumentados e trazê-los para a formalidade.

Nesse sistema há um considerável entrosamento entre os órgãos, contudo ainda insuficiente para solucionar a demora nos processos burocráticos e sujeitos às falhas pela falta de cruzamento de dados dos migrantes.

Ao Ministério da Justiça incumbe o controle da situação do migrante após o seu ingresso em território nacional, concedendo, prorrogando ou alterando vistos, além da concessão de asilo territorial, naturalizações e medidas compulsórias como extradição, deportação, expulsão ou repatriação. ${ }^{223}$

A atuação do Ministério da Justiça no controle da migração se dá por intermédio do Departamento de Estrangeiros, que, por sua vez, possui no organograma o Comitê Nacional para os Refugiados (Conare), órgão que conduz a política nacional para os refugiados no País e, para tanto, conta com o suporte da Coordenação-Geral de Assuntos de Refugiados.

Em 2008, o Ministério da Justiça criou a Secretaria Especial para coordenar o Plano Nacional de Enfrentamento ao Tráfico de Pessoas (PNETP), que atua na prevenção e repressão ao tráfico, na responsabilização dos autores e na atenção às vítimas. Assim, todo o migrante admitido em território brasileiro, independentemente do visto concedido, fica

223 Informações compiladas a partir do levantamento realizado por Luciana Unis Coentro, Políticas públicas e gestão das migrações internacionais do Brasil: uma reflexão sobre os migrantes qualificados, p. 106112. 
obrigado a cadastrar-se junto à Polícia Federal (Coordenação-Geral de Polícia de Imigração).

À Polícia Federal compete o controle migratório nas fronteiras, atuando simultaneamente como intermediário entre o migrante e o Ministério da Justiça, durante os processos de visto de permanência, pedidos de prorrogações de visto de trabalho e pedidos de naturalização. Os trabalhadores portadores de vistos temporários ou permanentes, exceto o portador para fins de viagem a negócios, são obrigados a registro no Ministério da Justiça em até 30 dias da data da entrada no país, conforme dispõe o art. 30, combinado com o art. 13, I, IV a VI, do Estatuto do Estrangeiro.

Não o fazendo nesse prazo, o migrante sujeita-se ao pagamento de multa diária, conforme art. 125, III. Na prática, esse prazo colide com os demais procedimentos e, não raro, o migrante fica impedido de ter o contrato registrado nos sistemas da empresa contratante por falta do número da Identidade ou do número do PIS, causando enormes transtornos na vida do migrante.

No exercício de tais competências, a Polícia Federal criou diversos sistemas de registro, dentre eles o Sistema de Registro e Cadastro de Estrangeiros (SINCRE), o Sistema de Tráfego Internacional (SINTE) e Sistema de Acompanhamento de Processos (SIAPRO). É da Polícia Federal ainda a competência para a emissão da Cédula de Identidade do Estrangeiro (CIE). ${ }^{224}$

Ao Ministério das Relações Exteriores cumpre, como órgão de governo, a condução das negociações sobre o tema migratório com outros países, promovendo acordos bilaterais ou multilaterais, a exemplo dos acordos sobre Previdência Social. O Ministério das Relações Exteriores também atua na defesa dos brasileiros que vivem no exterior e a estrangeiros que pretendam vir ao Brasil.

Os Ministérios da Ciência e Tecnologia (MCT) e da Educação (MEC) atuam nas principais agências de fomento à formação de pesquisa do Brasil, a exemplo do

224 Disponível em: 〈http://serviços.dpf.gov.br/sincreWeb/pesquisaAndamento.jsp〉. Acesso em: 2 out. 2013. 
Conselho Nacional de Desenvolvimento Científico e Tecnológico (CNPq - MCT) e a Coordenação de Aperfeiçoamento de Pessoa de Nível Superior (CAPES - MEC).

Segundo Coentro, essas duas agências têm atuado de forma positiva na intermediação de programas de concessão de bolsas de estudo e intercâmbio de estudantes e pesquisadores brasileiros no exterior, para aprimoramento da formação acadêmica, bem como na recepção de estrangeiros em nossas universidades, ampliando a base de conhecimento de estudantes, professores e profissionais em geral, e contribuindo para a assimilação de novas tecnologias. ${ }^{225}$

A Receita Federal, dado o seu isolamento dos demais órgãos, possui apenas as informações restritas aos migrantes que declaram a renda e oferecem os rendimentos à tributação. No entanto, em virtude da falta de cruzamento de dados com a Polícia Federal, as informações sob o controle da Receita Federal não permitem ao órgão conhecer o número de migrantes que exercem atividade econômica remunerada no país e não oferecem a renda à tributação.

Como era de esperar, esse sistema é ainda moroso e burocrático, pois as competências se chocam, os órgãos, como é comum em estruturas fragmentadas, não se comunicam e não atuam sob os mesmos objetivos. Como resultado dessa atuação descoordenada, não há uma agenda para a construção de políticas públicas que possam atender aos anseios dos migrantes e à necessidade de se adotar uma estratégia de desenvolvimento econômico para o País.

\subsubsection{Vistos}

A concessão do visto, segundo o que se extrai do Decreto n. 86.715/1981 e da Resolução Normativa n. 09/1997, compete às missões diplomáticas brasileiras localizadas no país de residência do interessado na obtenção do visto, que poderá ser emitido nas seguintes categorias, previstas no art. $4 .^{\circ}$ do Estatuto do Estrangeiro: I - de trânsito; II - de

${ }^{225}$ Luciana Unis Coentro, Políticas públicas e gestão das migrações internacionais do Brasil: uma reflexão sobre os migrantes qualificados, p. 113. 
turista; III - temporário; IV - permanente; V - de cortesia; VI - oficial; e VII diplomático.

Para os propósitos de nosso estudo, afiguram-se relevantes o visto temporário e o permanente, que serão abordados a seguir.

\section{- Visto temporário}

A concessão do visto temporário, que permitirá a estadia no período entre 90 dias até dois anos, se dá em função da finalidade da vinda do estrangeiro ao Brasil. De acordo com o art. 12 do Estatuto, o visto temporário poderá ser concedido ao estrangeiro que pretender ingressar no país para: I - viagem cultural ou missão de estudos; II - em viagem de negócios; III - na condição de artista ou desportista; IV - na condição de estudante; V - na condição de cientista, professor, técnico ou profissional de outra categoria, sob contrato ou a serviço do governo brasileiro; VI - na condição de correspondente de jornal, revista, rádio, televisão ou agência de notícias estrangeiras; e VII - na condição de ministro de confissão religiosa.

$\mathrm{O}$ art. 3. ${ }^{\circ}$ do atual Estatuto do Estrangeiro condiciona a concessão do visto pela autoridade consular aos interesses nacionais. Não há, obviamente, nenhum critério definido em lei sobre quais seriam exatamente os interesses nacionais que poderiam privar um indivíduo de ingressar no País, excetuando-se questões de natureza criminal. O fato é que o visto, tal como prevê o art. 26, "configura uma mera expectativa de direito", que poderá ser obstado inclusive, pela inconveniência da presença do indivíduo no território nacional.

\section{- Principais restrições do visto temporário}

A concessão do visto temporário exige, entre outras provas estabelecidas no art. 23 do Regulamento, a prova de possuir meios de subsistência, que consiste em carta convite da empresa ou da instituição à qual o estrangeiro estiver vinculado.

O estrangeiro sob vínculo temporário não poderá exercer cargo ou função de administração, gerência ou diretoria de sociedade comercial ou civil. Tampouco poderá se 
inscrever em Conselhos fiscalizadores do exercício de profissão regulamentada, exceto se o temporário foi admitido sob regime de contrato de trabalho ou a serviço do Governo brasileiro (Estatuto, art. 99, parágrafo único).

Não há liberdade de trabalho. Conforme o art. 100 do Estatuto, o estrangeiro admitido na condição de temporário sob regime de contrato de trabalho, só poderá exercer atividade junto à entidade pela qual foi contratado. Excepcionalmente, o Ministério da Justiça, ouvido o Ministério do Trabalho, poderá autorizar a alteração de empregador.

Qualquer infração das restrições acima expostas sujeitará o estrangeiro ao cancelamento de seu registro no Brasil e à deportação, conforme prevê o art. 125, X, do Estatuto.

- Visto permanente

O visto permanente, regulado no art. 16 do Estatuto, é claramente voltado a propiciar o ingresso de estrangeiros altamente qualificados, e poderá ser concedido ao estrangeiro que pretenda se fixar definitivamente no Brasil, com a finalidade de oferecer atividade especializada para setores da economia nacional, voltada a propiciar aumento da produtividade, assimilação de tecnologia e captação de recursos para setores específicos.

\section{- Principais restrições do visto permanente}

Embora denominado de permanente, de acordo com o art. 19 do Estatuto, o visto será concedido por prazo máximo de cinco anos, e sujeito ao exercício de atividade certa e fixação em determinada região do território nacional. A infração às condições de admissibilidade como permanente expõe o estrangeiro ao cancelamento de seu registro e à deportação (Estatuto, art. 125, X).

- Livre trânsito e residência aos nacionais de países-membros do Mercosul

Conforme pontuamos no capítulo anterior, os cidadãos do Mercosul têm direito a um tratamento diferenciado e à liberdade de residirem temporariamente em qualquer dos 
países-membros pelo prazo de dois anos, que poderá ser convertido em caráter definitivo, desde que comprove possuir meios para sua subsistência e de seus familiares.

\section{- Trânsito limitado do trabalhador fronteiriço}

O trabalhador fronteiriço ingressa no Brasil segundo os procedimentos simplificados previstos no art. 21 do Estatuto do Estrangeiro, que lhe assegura livre trânsito, porém, como destacam Santos e Farina, tem seu direito de acesso ao trabalho restrito às cidades contíguas da região fronteiriça, condição que o coloca sob desigualdade em relação aos trabalhadores nacionais. ${ }^{226}$

\subsubsection{Conselho Nacional de Imigração e autorizações de trabalho}

O Conselho Nacional de Imigração foi criado pelo Decreto 86.715, de 1981, sendo integrado por um representante do Ministério do Trabalho e Emprego, que o presidirá, um do Ministério da Justiça, um do Ministério das Relações Exteriores, um do Ministério da Agricultura, um do Ministério da Saúde, um do Ministério da Indústria e do Comércio e um do Conselho Nacional de Desenvolvimento Científico e Tecnológico.

O CNIg atua na definição e adequação das autorizações de trabalho solicitadas por migrantes às necessidades dos vários segmentos econômicos.

Convém pontuar que o número de migrantes que pleiteia ingresso com motivação de trabalho no Brasil ainda não é numericamente significativo, quando comparado aos demais países das Américas e do Caribe. Segundo dados da Organização Mundial para Migração, o Brasil recebeu em 2010 um total de 688.026 migrantes internacionais. Os Estados Unidos continuaram liderando o ranking, com 20\% do número total dos migrantes internacionais em todo o mundo, cerca de 42,8 milhões no ano de 2010. O Canadá recebeu 7,2 milhões, enquanto a Argentina recebeu 1,4 milhão. ${ }^{227}$

\footnotetext{
226 Enoque Ribeiro dos Santos e Bernardo Cunha Farina, Revista do Ministério Público do Trabalho/Procuradoria-Geral do Trabalho, p. 249.

227 Disponível em: <http://www.iom.int/jahia/Jahia/about-migration/facts-and-figures/americas-facts-andfigures>. Acesso em: 24 jun. 2012.
} 
O número de trabalhadores migrantes internacionais no Brasil, contudo, tende a crescer. No primeiro semestre de 2010, o Conselho Nacional de Imigração concedeu a maior quantidade de vistos a estrangeiros, crescimento de cerca de $26 \%$ comparado ao primeiro semestre de 2009.

Segundo Paulo Sérgio de Almeida, coordenador do Conselho, o aumento do número de vistos está associado a esse momento importante de crescimento econômico e forte desenvolvimento do País, em que as empresas estão com projetos de expansão de serviços e na área de offshore, petróleo e gás, são os maiores investimentos. ${ }^{228}$

Nesse contexto econômico positivo, o Conselho Nacional de Imigração lança um olhar positivo a esse contingente de estrangeiros que concorrem aos vistos de trabalho, ciente de que são realmente profissionais capacitados que aqui aportam para implantar projetos e, portanto, não concorrem com a mão de obra brasileira e ainda deixam aqui a sua colaboração com o desenvolvimento de negócios, que em consequência geram empregos locais.

Esse contingente de migrantes de que trata o Conselho Nacional de Imigração constitui o que podemos denominar de migrantes voluntários, que se caracterizam por uma opção, em geral, pela busca de melhores condições de vida.

Entretanto, simultaneamente, convivemos com as migrações forçadas que são resultados de fatos dramáticos, pelo necessário abandono do lugar onde a pessoa tem desenvolvido sua vida e estabelecido suas raízes sociais e culturais para dirigir-se a um novo ambiente.

Segundo dados do Ministério da Justiça de 2010, estima-se que viviam aqui cerca de 900 mil migrantes ilegais no Brasil. O número é considerado maior pelo Serviço Pastoral dos Migrantes, que se estima que existam 600 mil. Segundo dados do Centro Pastoral do Migrante, a maioria dos migrantes paulistanos é boliviana e o perfil das

228 Seminário Mão de obra estrangeira no Brasil e brasileira no exterior. Perguntas dirigidas ao Dr. Paulo Sérgio de Almeida, Coordenador-Geral de Imigração, Ministério de Trabalho e Emprego. 
famílias é variado, "como trabalhadores de oficinas de costura, pessoas com problemas de saúde, desempregados, sem documentação etc.". 229

As questões envolvendo um e outro contingente de migrantes são naturalmente complexas e comumente examinadas à luz da globalização da economia, que por sua vez favorece a volatilidade do capital em busca de cenários econômicos mais favoráveis e baixo custo de mão de obra.

O CNIg tem cumprido o papel de fazer políticas públicas, de administrar tensões entre empresários, órgãos de outros ministérios e de regulamentar a concessão de vistos, conforme

O órgão tem como atribuições, as atividades dispostas no art. 144 do Decreto, a saber:

I - orientar e coordenar as atividades de migração;

II - formular objetivos para elaboração da política imigratória;

III - estabelecer normas de seleção de migrantes, visando proporcionar mão de obra especializada aos vários setores da economia nacional e à captação de recursos para setores específicos;

IV - promover ou fomentar estudo de problemas relativos à imigração;

$\mathrm{V}$ - definir as regiões de que trata o art. 18 a Lei n. 6.815, de 19.08.1980, e elaborar os respectivos planos de imigração;

VI - efetuar o levantamento periódico das necessidades de mão de obra estrangeira qualificada, para admissão em caráter permanente ou temporário;

VII - dirimir as dúvidas e solucionar os casos omissos, no que respeita à admissão de migrantes;

VIII- opinar sobre alteração da legislação relativa à imigração, proposta por órgão federal;

IX - elaborar o seu Regimento Interno, a ser submetido à aprovação do Ministro do Trabalho.

Parágrafo único. As deliberações do Conselho Nacional de Imigração serão fixadas por meio de Resoluções.

229 Entrevista realizada com Sônia, da Secretaria do COM. Disponível em: <http://www.gpopai. usp.br/cursos/index.php/Entrevista>. Acesso em: 24 jun. 2012. 
As Resoluções Normativas têm origem em um processo de criação muito peculiar e que foi registrado por Boucinhas e Barbas, com resultado de entrevista realizada em 2010, com Representante no CNIg. ${ }^{230}$

Em síntese, lembrando, como exposto acima, que o CNIg é integrado por várias entidades que atuam como órgão colegiado, as sugestões de alterações de Resoluções têm origem nas reuniões periódicas desse colegiado, e são levadas aos grupos de estudos tripartites, formados por representantes dos trabalhadores, do setor empresarial e do governo. O grupo discute a questão e em consenso elabora uma sugestão de texto para uma nova norma, ou a alteração ou a revogação de uma norma existente, a qual é submetida à votação entre os integrantes do CNIg. Uma vez aprovada, a norma é publicada no Diário Oficial da União, entrando em vigor na data prescrita na própria Resolução.

Um ponto positivo do manejo das Resoluções Normativas é sem dúvida a maior rapidez no trato de questões de ingresso de migrantes. $\mathrm{O}$ ponto negativo, bem pontuado por Boucinhas e Barbas, decorre da clara orientação do CNIg para a elaboração de normas que tratam exclusivamente do ingresso de migrantes especializados. Ademais, "não há fonte pública e aberta" que permita acesso aos documentos produzidos por esses grupos de estudos, cuja posse é confiada exclusivamente ao Presidente do CNIg.

No período entre abril de 1997 a maio de 2013, o CNIg expediu 104 Resoluções Normativas sobre procedimentos relacionados à autorização de trabalho a estrangeiros. As Resoluções podem ser ainda administrativas, recomendadas e normativas. $^{231}$

As resoluções administrativas tratam da organização interna do Conselho. Já as resoluções recomendadas, como o nome já indica, cuidam de assuntos para os quais o CNIg expede recomendações a outros órgãos sobre casos de concessão de vistos.

Finalmente, as conhecidas Resoluções Normativas atuam no vácuo existente em razão da ausência de uma legislação moderna de migração e procuraram orientar e

230 Jorge Cavalcanti Boucinhas Filho e Leandro Moreira Valente Barbas, Migração de trabalhadores para o Brasil, p. 48-50.

231 Disponível em: <http://portal.mte.gov.brldatalfiles\FF8080812BAB0D259>. Acesso em: 22 set. 2013. 
coordenar as atividades de imigração, com intuito de proporcionar os profissionais necessários aos vários setores da economia nacional.

A seguir, destacamos as Resoluções Normativas $(\mathrm{RN})$ de maior relevância à tipologia de migração para o Brasil:

\subsubsection{Intercâmbio profissional}

A RN n. 94, de 16.03.2011, disciplina a concessão de visto de até um ano a estrangeiro, estudante ou recém-formado, que venha ao Brasil no âmbito de programa de intercâmbio profissional, mediante comprovação de matrícula ou certificado de conclusão de curso há menos de um ano, além da apresentação de contrato de trabalho temporário e termo de compromisso entre o estrangeiro e a entidade empregadora, com participação de entidade brasileira de intercâmbio interveniente.

A referida $\mathrm{RN}$ dispõe no art. $3 .^{\circ}$ que o pedido de visto poderá ser indeferido se houver indício de interesse da empresa em efetuar mera substituição de mão de obra nacional por profissionais estrangeiros e se for constatado que o mesmo tratamento não é dispensado aos brasileiros no país de origem do interessado.

\subsubsection{Eventos esportivos}

A RN n. 98, de 14.11.2012, disciplina a concessão de autorização de trabalho pelo prazo de um ano, a estrangeiro que venha trabalhar no Brasil, exclusivamente, na preparação, organização, planejamento e execução da Copa das Confederações FIFA 2013, da Copa do Mundo FIFA 2014 e dos Jogos Olímpicos e Paraolímpicos Rio 2016. Os dependentes do estrangeiro autorizado nos termos da RN n. 98 poderão trabalhar no País, desde que sejam chamados por empregador estabelecido no Brasil e individualmente obtenham o respectivo visto temporário. 


\subsubsection{Assistência técnica}

A RN n. 61, de 08.12.2004, disciplina a autorização de trabalho e de visto a estrangeiro, pelo prazo máximo de um ano, sob contrato de transferência de tecnologia e ou prestação de serviço de assistência técnica, de acordo de cooperação ou convênio, sem vínculo empregatício ou em situação de emergência. Em situações de emergência, o visto poderá ser concedido uma vez a cada período de noventa dias.

A RN n. 100, de 23.04.2013, flexibiliza o ingresso de estrangeiro que pretenda vir ao Brasil, sem vínculo empregatício, para transferência de tecnologia ou para prestar serviço de assistência técnica por prazo determinado de até 90 dias, em decorrência de contrato ou convênio firmado entre pessoa jurídica estrangeira e pessoa jurídica brasileira. O visto, nesses casos, poderá ser concedido diretamente pela Repartição Consular Brasileira no exterior, mediante carta convite da empresa "chamante" sediada no Brasil. Trata-se de um visto de curta duração, não sendo permitida a sua prorrogação ou transformação em permanente. Constatados indícios de substituição de mão de obra nacional por profissional estrangeiro ou pressupostos de relação de emprego com a empresa brasileira, o visto será cancelado, conforme o art. $2^{\circ}{ }^{\circ}$, parágrafo único, da RN n. $100 / 2013$.

\subsubsection{Trabalho sob vínculo empregatício}

A RN n. 99, de 12.12.2012, disciplina a concessão de autorização de trabalho para obtenção de visto de trabalho a estrangeiro com vínculo empregatício no Brasil. $\mathrm{O}$ trabalho poderá ser prestado tanto à pessoa física como à pessoa jurídica. Todavia, o pedido será analisado com respeito ao interesse do trabalhador brasileiro.

$\mathrm{Na}$ apreciação do pedido, será examinada a compatibilidade entre a qualificação e a experiência do estrangeiro e a atividade que virá exercer no País. No art. 2. ${ }^{\circ}$ exigem-se comprovação da qualificação e experiência profissional, escolaridade mínima de nove anos e experiência de dois anos em ocupação que não exija nível superior; ou experiência de um ano no exercício da profissão de nível superior, contando esse prazo da conclusão do curso de graduação que o habilitou a esse exercício; ou conclusão de curso de pós-graduação, com no mínimo 360 horas, ou de mestrado ou grau superior compatível 
com a atividade que desempenhará. Essa exigência não se aplicará quando se tratar de pedido de autorização de trabalho para nacional de país sul-americano.

\subsubsection{Treinamento sem vínculo empregatício}

A RN n. 87, de 15.09.2010, disciplina a concessão de visto a estrangeiro por prazo de até um ano, sem vínculo empregatício, para receber treinamento profissional, mantendo-se vinculado a empresa estrangeira, enquanto é treinado junto à filial, subsidiária ou matriz brasileira do mesmo grupo econômico. O pedido de visto exigirá apresentar justificativa da necessidade de treinamento no Brasil e declaração de que a remuneração do estrangeiro provirá de fonte no exterior. Novamente, verifica-se na NR n. 87 , art. $3 .^{\circ}$, a advertência de que o pedido de visto poderá ser indeferido se restar caracterizado indício de interesse da empresa em efetuar mera substituição de nacional por profissionais estrangeiros.

\subsubsection{Investidor estrangeiro}

A RN n. 84, de 10.02.2009, disciplina a concessão de autorização para fins de obtenção de visto permanente para investidor estrangeiro - pessoa física, condicionada à comprovação de investimento em moeda estrangeira, em montante igual ou superior a $\mathrm{R} \$$ 150.000,00 em empresa nova ou existente. $\mathrm{O}$ valor do investimento poderá ser reduzido se verificado o interesse social pela geração de empregos, setor econômico em que ocorrerá o investimento e contribuição para o aumento da produtividade ou assimilação de tecnologia.

\subsubsection{Trabalho a bordo de embarcação ou plataforma}

A RN n. 71, de 10.10.2006, alterada pela RN n. 105, de 23.09.2013, disciplina a chamada de profissionais estrangeiros para trabalho a bordo de embarcação ou plataforma estrangeira, e de acordo com a nova redação a autorização será outorgada ao marítimo de uma mesma embarcação que dela necessite, pelo prazo de até dois anos, improrrogável. 


\subsubsection{Representação de instituição financeira}

A RN n. 63, de 06.07.2005, regula a autorização de trabalho e a concessão de visto permanente a estrangeiro para representar, no Brasil, instituição financeira ou assemelhada sediada no exterior. Não se trata especificamente do gestor, porquanto as atividades do candidato ao visto se subordinam a restrições impostas pelas normas expedidas pelo Banco Central do Brasil, dispostas no art. 1. ${ }^{\circ}$, que descreve as atribuições como a realização de contatos comerciais e a transmissão de informações de interesse da matriz ou de filiais no exterior.

\subsubsection{Administrador com ou sem vínculo empregatício}

A RN n. 62, de 08.12.2004, com alterações promovidas pela RN n. 95, de 10.08.2011, disciplina a concessão de autorização de trabalho e de visto permanente a estrangeiro. Administrador, Gerente, Diretor, Executivo, com poderes de gestão, e sociedade civil ou comercial, grupo ou conglomerado econômico. A sociedade deverá comprovar investimento em moeda estrangeira em montante igual ou superior a $\mathrm{R} \$$ $600.000,00$ por indivíduo, ou igual ou superior a $R \$ 150.000,00$, se comprovada a geração de dez novos empregos durante os dois anos posteriores à instalação da empresa ou entrada do indivíduo.

O objetivo da RN n. 62 é claramente prover uma compensação ao trabalhador nacional em razão da permissão concedida à empresa aqui estabelecida para preencher seus quadros com migrantes altamente qualificados, e essa lógica pode ser identificada a partir da análise da evolução das normas do CNIg que resultaram nesta RN.

Segundo levantamento realizado por Boucinhas e Barbas, houve um período de transição de Resoluções que se situa entre 1994 e 2003, em que o CNIg editou três normas, mediante as quais o empresário assumia pesados custos para viabilizar o ingresso e a permanência de altos executivos no País.

O visto era concedido por apenas 90 dias e para fins de negócios, condição que impedia o estrangeiro de representar a empresa perante terceiros e de participar de atos de gestão, na tentativa de estabelecer um equilíbrio entre a necessidade das empresas 
contarem com migrantes altamente qualificados em postos de gestão dos negócios e a proteção do mercado nacional, carente de recursos. ${ }^{232}$

Do exposto, nota-se que o papel do CNIg é o de facilitador do ingresso do estrangeiro, promovendo uma interação rápida com o empresariado e com a comunidade, regulamentando uma imensa variedade de situações nas quais se justifica a autorização de ingresso e permanência do estrangeiro. Na imigração a trabalho é onde se encontram as maiores restrições, voltadas nitidamente à proteção dos profissionais nacionais.

Em pelo menos quatro Resoluções, o CNIg adverte que não será tolerado o uso do trabalho estrangeiro para substituição de profissionais brasileiros ou a utilização de vínculos temporários precários como forma de evitar a relação empregatícia entre a empresa "chamante" e o estrangeiro.

\subsection{Tutela jurídico-trabalhista dos migrantes no Brasil}

\subsubsection{Aspectos gerais}

Ultrapassado o processo de admissão do trabalhador migrante em território nacional, estabelece-se a relação jurídica entre empresas e migrantes.

No presente tópico apresentamos as características e as peculiaridades das relações jurídicas que se estabelecem entre o trabalhador migrante e a empresa "chamante", assim entendida a pessoa jurídica ou física que patrocinou o visto e a autorização de trabalho do migrante.

No Brasil, à exceção do investidor pessoa física, que tiver R \$ 150.000,00 para iniciar seu próprio negócio ou investir em empresa já constituída, o trabalhador migrante necessita de um convite ou patrocínio de uma empresa instalada no território brasileiro para dar início ao seu processo de visto de trabalho no Brasil e ficará vinculado a essa pessoa jurídica ou física ao menos durante o período de dois anos, até que esteja apta a convertê-lo em visto permanente. Importante destacar que, mesmo o migrante que

232 Jorge Cavalcanti Boucinhas Filho e Leandro Moreira Valente Barbas, Migração de trabalhadores para o Brasil, p. 54-55. 
ingressar no Brasil com um visto considerado permanente para fins de gestão de sociedade civil ou comercial, ficará vinculado ao chamante nos dois primeiros anos do contrato.

Diferente do que ocorre no Reino Unido, por exemplo, aqui o migrante, ainda que possua um nível de formação acadêmica e profissional que o defina como altamente qualificado, seu visto de ingresso e sua autorização para o trabalho dependerão do patrocínio de uma empresa ou uma pessoa física no Brasil.

Outro traço marcante das políticas brasileiras é a total ausência de previsão para o trabalho de migrantes sem qualificação, de baixa escolaridade. Diferente do que ocorre na Europa, onde muitos países, a exemplo da Alemanha e da França, permitem ao empresário contratar os serviços de migrantes para atividades que não são absorvidas pelos nacionais, o Brasil não dispõe de nenhuma regulamentação nesse sentido.

De um lado, essa opção muito provavelmente se explica diante do enorme contingente de brasileiros jovens, desempregados e sem qualificação. Essa afirmação encontra-se no relatório Territorial divulgado pela Organização para Cooperação e Desenvolvimento Econômico (OCDE), observando que, apesar da queda continuada do desemprego no Brasil, os jovens ainda enfrentam dificuldades significativas no mercado de trabalho, em grande parte em virtude da deficiência de educação e treinamento adequados. Portanto, o elevado contingente de jovens com baixa qualificação pode ser um dos fatores a explicar a falta de motivação para a abertura das fronteiras para migrantes igualmente sem qualificação. ${ }^{233}$

Por outro lado, com o Acordo de Residência do Mercosul, o Brasil, a priori, permite o ingresso de trabalhadores migrantes de países-membros e associados sem nenhuma exigência de qualificação.

Ao analisarmos os direitos e os deveres do trabalhador migrante, é comum que nosso primeiro olhar se volte para as relações que se estabeleceram no território do país de destino do migrante, com intuito de garantir ao migrante o acesso aos direitos sociais em igualdade de condições aos trabalhadores nacionais.

233 Relatório Territorial da OCDE: Brasil 2013. Disponível em: <http://www.oecd-ilibrary.orflurban-ruraland-regional-depvelopn>. Acesso em: 21 out. 2013. 
É justamente o que defendemos no item anterior em que criticamos as restrições impostas ao migrante, a exemplo da burocracia dos vistos de ingresso, das restrições ao pleno exercício da profissão, da ultrapassada regra de proporcionalidade entre o número de brasileiros em relação ao estrangeiro, da proibição de rescisão do contrato de um brasileiro, por falta de serviço, sem que um trabalhador migrante tenha sido dispensado previamente ao brasileiro.

Ao avançarmos sobre as características contemporâneas da mobilidade internacional, vamos nos deparar com muita frequência com situações envolvendo trabalhadores que foram contratados em seus países de origem por uma determinada empresa e, posteriormente, transferidos para prestarem serviços em outro país, para outra entidade legal, que possui laços de conexão com a empresa para a qual o indivíduo trabalhava em seu país de origem.

Podemos nos deparar, ainda, como um cidadão submetido não só a dois, mas até três ordenamentos jurídicos, se cogitarmos de um trabalhador brasileiro, transferido para prestar serviços a uma empresa do mesmo grupo econômico sediada na Alemanha, submetida a regras de direito comunitário da União Europeia. Nessa conformação, o migrante carregará consigo as regras da Lei n. 7.064/1982, que dispõe sobre a aplicação da lei brasileira em relação a alguns direitos, como a manutenção dos depósitos do FGTS e os recolhimentos da contribuição à Previdência Social; contará com a aplicação da legislação de proteção trabalhista da Alemanha e às Diretivas da UE.

Trata-se de um reflexo direto da globalização do capital e do consequente incremento do processo de internacionalização das empresas. Esse fenômeno expande a atuação tanto de empresas estrangeiras no Brasil quanto de empresas brasileiras no exterior e torna necessária a utilização de trabalhadores migrantes. Não raro, as relações jurídicas trabalhistas envolvem a aplicação de direitos e encargos trabalhistas, previdenciários e fiscais previstos em mais de uma legislação nacional, acarretando enorme insegurança jurídica às partes.

Esses liames da mobilidade do trabalho, marcados pelo caráter de provisoriedade, constituem um campo farto à nossa investigação sobre critérios de igualdade e ética da migração a trabalho, uma vez permeadas de conflitos sobre regras 
trabalhistas aplicáveis durante o período de estada em outro território e não raro afetam e modificam relações constituídas antes e após a conclusão da estada do migrante no território do país de destino.

Lidar com um conjunto de direitos informado pela prerrogativa de cada Estado em fixar as condições de entrada, permanência e de acesso a direitos sociais acarreta inerente restrição ao pleno exercício de direitos sociais.

\subsubsection{Restrições ao exercício de profissão liberal e revalidação de diplomas}

Embora a Constituição de 1988 assegure, no art. 5. ${ }^{\circ}$, XIII, a liberdade para o exercício de qualquer trabalho, ofício ou profissão, atendidas as qualificações que a lei estabelecer, nos defrontamos com repetidas situações nas quais os trabalhadores migrantes se veem seriamente afetados com a falta de reconhecimento de suas qualificações e experiências profissionais prévias.

O reconhecimento mútuo de diplomas e de formação escolar e profissional é um processo difícil até mesmo entre países-membros de blocos econômicos. Para se ter uma ideia da complexidade do tema, a União Europeia demandou mais de 30 anos de preparação para a adoção de políticas de aproximação e diretivas especializadas, para a harmonização de regras gerais sobre o exercício de profissões liberais e regulamentadas, como advogados, médicos, engenheiros, veterinários. Em 1988, foram aprovadas as regras para um sistema geral de reconhecimento de diplomas de ensino superior, que resultou na Diretiva n. $1.989 / 48 .^{234}$

No Brasil, o trabalhador migrante qualificado se sujeitará a uma dupla habilitação:

i. habilitação profisssional ou acadêmica, prevista na Lei n. 9.394/1996 - Lei de Diretrizes e Bases da Educação Nacional - que, em seu art. 48, § 2. , exige que os diplomas de graduação expedidos por universidades estrangeiras sejam revalidados por universidades públicas que possuam

234 Marilia Costa Morosini (Org.), Mercosul: políticas e ações universitárias, p. 34. 
cursos de mesmo nível e área equivalente, respeitando-se acordos internacionais de reciprocidade ou equiparação; e

ii. habilitação legal, que consiste na autorização concedida pelos Conselhos Profissionais que regem o exercício de determinadas profissões no país, sobretudo quando se verifica incompatibilidade do conteúdo ou da aplicação do conhecimento nos respectivos cursos de graduação entre o país de origem e o Brasil.

A rigor, os Conselhos Profissionais detêm a prerrogativa para o registro e deliberação sobre as regras de atuação e a fiscalização do exercício das profissões que representam.

Nem todas as profissões, trabalhos, ofícios contam com órgãos de classe organizados a representarem os profissionais que nelas atuam, sobretudo os ofícios que demandam baixa qualificação e escolaridade.

As mais simples e que exigem menor tempo de formação técnica, em geral, não oferecem restrições ao trabalhador migrante, a exemplo dos serviços de faxina, pedreiro, encanador, eletricista, técnicos de eletrodomésticos em geral. Todavia, justamente por se constituírem em ocupações mais simples, tolhem a liberdade do trabalhador migrante no seu exercício já no ato de concessão do visto de ingresso no País, porque, sob a égide do atual Estatuto do Estrangeiro, o trabalhador migrante que não possua qualificação técnica ou profissional relevante não preencherá nenhum dos requisitos para que possa ingressar regularmente no País e aqui trabalhar em ocupação e ofício que garantam sua subsistência e a de sua família.

Exceção feita aos mercosulinos e aos fronteiriços, desde que abrangidos pelo Acordo de Residência do Mercosul, em vigor no Brasil desde 2009, e que permite que possam aqui residir provisoriamente por até dois anos com ampla liberdade de exercício de qualquer ocupação, resguardadas, obviamente, as restrições e os requisitos estabelecidos para aquelas profissões regulamentadas. 
Quanto aos migrantes fronteiriços, na condição de nacionais de países não abrangidos pelo Mercosul, ou com os quais o Brasil não tenha firmado acordo bilateral de Residência, a exemplo da Guiana Francesa, Suriname, Guiana, estão sujeitos às regras do Estatuto do Estrangeiro e normas do CNIg, as quais tampouco lhes conferem ampla liberdade de trabalho, restrita que está ao âmbito do território das cidades fronteiriças.

Retomando a situação dos migrantes qualificados, as restrições de exercício da profissão decorrem da necessidade de reconhecimento de diplomas e de autorização dos Conselhos Profissionais para o exercício da profissão, como demonstramos adiante.

\subsubsection{Advocacia}

Exemplo conhecido de restrição ao pleno exercício de determinada profíssão se dá na advocacia. O antigo Estatuto da Ordem dos Advogados do Brasil, Lei n. 4.215, de 27.04.1963, art. 48, parágrafo, já restringia o pleno exercício da profissão por estrangeiros, e tal restrição foi repetida no atual Estatuto da Advocacia, Lei n. 8.906, de 1994.

A vedação, contudo, atinge o profissional que não revalidou o seu diploma de graduação, mediante procedimento que envolve universidade brasileira autorizada pelo Ministério da Educação para tanto.

Assim, não tendo se graduado em Direito no Brasil, o advogado migrante que decida não revalidar seu diploma no País, se sujeitará ao Provimento n. 91, de 12.03.2000, da $\mathrm{OAB}$, o qual somente autoriza o estrangeiro a prestar serviços de advocacia mediante autorização precária expedida pela $\mathrm{OAB}$, que permite ao estrangeiro a prática exclusiva de consultoria do Direito estrangeiro correspondente ao do país do profissional interessado, sendo vedado o exercício da consultoria ou assessoria em matéria de Direito brasileiro. ${ }^{235}$

É importante esclarecer que a $\mathrm{OAB}$ não veda que o estrangeiro, e mesmo o brasileiro, graduado em Direito fora do Brasil, possa se inscrever na OAB e ter livre acesso

235 O inteiro teor do Provimento n. 91/2000, sobre o exercício da atividade de consultores e sociedade de consultores em direito estrangeiro no Brasil, está disponível em: <http://www.oab.org.br/ari/files/provimento91-2000.pdf>. Acesso em: 3 out. 2013. 
ao exercício da profissão no País, mediante a revalidação do diploma, conforme previsto no art. $8 .^{\circ}$, inciso $2 .^{\circ}$, do Estatuto.

A revalidação do diploma, conforme Parecer do Conselheiro Sérgio Ferraz, consiste em um procedimento administrativo, realizado pelas universidades autorizadas pelo Ministério da Educação, e que requer a análise do conteúdo do curso jurídico concluído no exterior, confrontando-o com as exigências mínimas postas aos cursos jurídicos no Brasil. Se necessário, o requerente deverá complementar a formação, para que o diploma possa ser reconhecido, mediante a prestação de provas. ${ }^{236}$

É verdade que esse processo de revalidação, como reconhece Ferraz, ainda demanda tempo injustificável, às vezes anos, por conta das tramitações burocráticas entre as universidades e o Ministério da Educação.

\subsubsection{Engenharia}

Os profissionais (brasileiros ou estrangeiros) diplomados no exterior, em áreas representadas pelo Conselho Federal de Engenharia e Agronomia (Confea), que, na sua concepção atual, é regido pela Lei n. 5.194, de 1966, representando também os geógrafos, geólogos, meteorologistas, tecnólogos e agrícolas e suas especializações, devem se submeter às regras da Resolução n. 1.007, de 05.12.2003, que dispõe sobre o registro e os critérios de expedição da Carteira de Identidade Profissional.

O profissional diplomado no exterior deverá submeter o título à análise do Conselho, visando à verificação da qualificação acadêmica, como pré-requisito à expedição da Carteira de Identidade Profissional para o pleno exercício da profissão no País.

236 O inteiro teor do Parecer sobre do Conselheiro está disponível em: <http://www.oab.org.br.br/ari/ files/parecer-sergioferraz.pdf>. Acesso em: 3 out. 2013. 
Aos estrangeiros portadores de visto temporário com contrato de trabalho temporário no Brasil, o exercício da profissão é restrito ao prazo e às atividades previstas no contrato de trabalho (art. 19, parágrafo único, da Resolução n. 1.007). ${ }^{237}$

Um requisito muito peculiar imposto a esses profissionais consiste na obrigação da empresa contratante, em manter junto ao profissional estrangeiro, portador de visto temporário, um profissional brasileiro de graduação idêntica ou superior, para atuar como auxiliar ou adjunto do estrangeiro.

Esse requisito nos parece ter como fundamento o interesse do Conselho na transferência de conhecimento e de tecnologia, mais do que uma restrição direta ao exercício da profissão no País.

Vale anotar que a maioria dos profissionais em comento ingressam no Brasil, sob os vistos previstos na RN n. 61, de 08.12.2004, e NR n. 100, de 23.04.2013, do CNIg, que disciplinam a autorização de trabalho e de visto a estrangeiro, pelo prazo máximo de um ano, sob contrato de transferência de tecnologia e ou prestação de serviço de assistência técnica, de acordo de cooperação ou convênio, sem vínculo empregatício. ${ }^{238}$

Sob essa modalidade de visto, o trabalhador migrante permanece vinculado à empresa sediada no exterior, da qual receberá os salários, igualmente pagos no exterior durante o período de estadia no Brasil. Aqui, o migrante terá seu trabalho extremamente restrito, pois ficará vinculado à pessoa jurídica contratante de serviços de assistência técnica ou transferência de tecnologia mediante contrato com outra pessoa jurídica no exterior.

O trabalhador, sob esse arranjo, terá no Brasil apenas o reembolso de despesas com sua estadia e não está sob a proteção do direito do trabalho, e não faz jus a nenhum direito trabalhista no Brasil, uma vez que é proibida a sua contratação sob vínculo empregatício, inclusive, o visto e a autorização de trabalho poderão ser cancelados, se

237 O inteiro teor da Resolução n. 1.007, de 05.12. 2003, sobre o registro de profissionais no Confea está disponível em: <http://confea.org.br/media/1007-03〉. Acesso em: 3 out. 2013.

238 O inteiro teor da RN n. 61/2004 está disponível em: <http://portal.mte.gov.br/data/files/ 8A7C812D3F9B201403B60B0A25B5/NOVO\%20\%atualizadofinal.pdf>. Acesso em: 3 out. 2013. 
detectados elementos configuradores de relação de emprego com a empresa sediada no Brasil.

A RN n. 100/2013 simplificou o visto para estrangeiros que pretendam vir ao Brasil para prestar serviços de assistência técnica por períodos de até 90 dias, sem vínculo empregatício. Essa categoria de profissionais poderá solicitar o visto diretamente, em Repartição Consular Brasileira no exterior, mediante apresentação de carta convite da empresa chamante, atestando o vínculo entre o estrangeiro e o serviço a ser prestado no Brasil, além de outras disposições contidas na norma. ${ }^{239}$

\subsubsection{Medicina}

No âmbito da medicina, Cahali ressalta o teor da Portaria conjunta dos Ministérios da Educação e da Saúde, que abriu a possibilidade para que médicos formados no exterior exerçam a profissão no Brasil, mediante a realização de uma prova aplicada pelo Instituto Nacional de Estudos e Pesquisas Educacionais (Inep). ${ }^{240}$

Recentemente, Convênios internacionais viabilizaram o ingresso de médicos estrangeiros de várias nacionalidades, para o exercício da profissão em regiões mais periféricas em que não há interesse de atuação por parte dos médicos brasileiros.

Um dos convênios intergovernamentais que viabilizou o ingresso no Brasil de médicos cubanos tem dividido a opinião da sociedade.

Antes de expormos a situação particular dos médicos cubanos, convém analisar o teor dos documentos firmados entre o governo brasileiro e as organizações internacionais e, bem assim, confrontá-lo com os instrumentos de proteção ao trabalhador migrante e a legislação nacional sobre o tema.

239 O inteiro teor da RN n. 100/2013 está disponível em: <http://portal.mte.gov.br/data/ files/8A7C812D3DCAF301E652CO7E319/Resolução20\%Normativa.pdf>. Acesso em: 3 out. 2013.

240 Yussef Said Cahali, Estatuto do Estrangeiro, p. 389. 


\section{- Termo de Cooperação}

Primeiramente, quanto ao termo de cooperação, trata-se do $80 .^{\circ}$ Termo de Cooperação Técnica para desenvolvimento de ações vinculadas ao projeto "Acesso da População Brasileira à Atenção Básica em Saúde”, celebrado em Brasília em 26.04.2013, entre a União, por intermédio do Ministério da Saúde e a Organização Pan-Americana da Saúde e a Organização Mundial da Saúde (OPAS).

Referido Termo se operacionalizará, na forma de sua Cláusula 4. ${ }^{\text {a }}$, mediante assinatura de Termos de Ajustes a serem firmados entre o Ministério da Saúde e a OPAS, com recursos financeiros providos pelo Ministério da Saúde.

\section{- Medida Provisória n. 621/2013}

Em seguida ao Termo de Cooperação, foi adotada a Medida Provisória n. 621, de 08.07.2013, que instituiu o Programa "Mais Médicos”.

De acordo com o art. 1. ${ }^{\circ}$ da Medida Provisória, o programa objetiva formar recursos humanos na área médica para o Sistema Único de Saúde (SUS), e será oferecido aos médicos brasileiros e estrangeiros. Estes últimos participam por meio de intercâmbio médico internacional, mediante comprovação de que é formado por instituição de educação estrangeira com habilitação para exercício de medicina no exterior (art. 70, inciso 2. ${ }^{\circ}$, II). Foi dispensada a revalidação do diploma (art. 10). ${ }^{241}$

\section{- Decreto n. 8.081/2013}

O Decreto n. 8.081, em vigor desde a data de sua publicação, em 23.08.2013, institui o Comitê Gestor e o Grupo Executivo do Programa "Mais Médicos”, e disciplina a emissão do registro profissional do médico pelos Conselhos Regionais de Medicina, desde

241 Inteiro teor da MP n. 621/2013 está disponível em: <http://www.planalto.gov.br/ ccivil_03/_Ato20112014mpv621htm>. Acesso em: 3 out. 2013. 
que apresentada a documentação necessária, estipulando o prazo de 15 dias para essa providência (art. 1. $\left.{ }^{\circ}\right) .^{242}$

Entretanto, há restrições ao pleno exercício profissional dos médicos cambistas. A Medida Provisória n. 621/2013 prevê, no art. 10, que o médico intercambista terá direito à expedição do registro provisório pelos Conselhos Regionais de Medicina (CRM), porém não poderá participar das eleições deste Conselho (art. 10, inciso $6^{\circ}{ }^{\circ}$ ).

O prazo do visto é de no máximo três anos e o médico não terá direito a vínculo empregatício. Nesse ponto, o art. 11 expressamente dispõe que "as atividades desempenhadas no âmbito do Projeto Mais Médicos para o Brasil não criam vínculo empregatício de qualquer natureza”.

Quanto à remuneração, o médico receberá apenas bolsas (formação, supervisão e tutoria) e o custeio das despesas. Deverá contribuir como contribuinte individual para o Regime Geral de Previdência Social (RGPS) brasileiro.

O acordo em comento impõe restrições ao exercício profissional de todos os profissionais estrangeiros, interessados em aderir ao programa, aspecto em que não se diferencia muito das restrições já expostas para a plena atuação de advogados, engenheiros e técnicos em geral.

$\mathrm{Na}$ verdade, todas essas restrições têm amparo no Estatuto do Estrangeiro, cujo art. 15, de teor extremamente discriminatório, dispõe que o estrangeiro referido no item III ou V do art. 13 (em que se incluem os artistas, desportistas, cientistas, professores, técnicos ou profissionais de outra categoria, sob regime de contrato ou a serviço do Governo brasileiro) só receberá o visto se satisfizer às exigências especiais estabelecidas pelo Conselho Nacional de Imigração e for parte em contrato de trabalho visado pelo Ministério do Trabalho e Emprego, salvo no caso de comprovada prestação e serviço ao Governo brasileiro.

${ }^{242}$ Inteiro teor do Decreto disponível em: <http://s.conjur.com.br/dl/decreto-medicos.pdf〉. Acesso em: 3 out. 2013. 
Logo, chegamos ao ponto central: os convênios, leis e medidas que deles decorrem fazem parte de um conjunto discriminatório que se instituiu a partir do Estatuto do Estrangeiro.

Esse é o ponto de partida e a raiz do problema que se coloca ao Brasil como um desafio a vencer. A expectativa é a de que a nova lei de migração possa superar esses entraves e determinar critérios igualitários de acesso do profissional migrante ao mercado de trabalho brasileiro. Essa ainda não é uma tendência internacional. Portanto, há que se pensar em atuar nos limites do que é possível dentro das peculiaridades da realidade brasileira.

Diante do exposto, retomamos a questão dos médicos de nacionalidade cubana, posto que há uma peculiaridade que justifica a abordagem. Trata-se da condição específica que se aplicará aos cubanos, e não aos demais médicos estrangeiros, e que consiste em negar-lhes o direito à percepção direta do pagamento pelos serviços prestados.

Até a data da conclusão do presente estudo, não tivemos êxito em obter acesso a conteúdo do termo de ajuste que, na sistemática do Termo firmado com a OPAS, acima exposto, deve ter sido firmado entre o Governo brasileiro e o cubano, para fins de regular o ingresso dos médicos de nacionalidade cubana em território brasileiro.

Publicou-se na mídia que a bolsa a ser paga aos médicos cubanos, em valor equivalente a R \$ 10.000,00, seria repassada ao governo cubano. Noticiou-se, ainda, que o Secretário Adjunto de Gestão do Trabalho e da Educação na Saúde do Ministério da Saúde teria declarado que aos médicos restaria o pagamento de uma bolsa entre $R \$ 2.500,00$ a $R \$$ 4.000,00. Além disso, publicou-se, ainda, que estariam impedidos de pedir asilo político no Brasil e não poderiam trazer as suas famílias para o País. ${ }^{243}$

Para Ives Gandra da Silva Martins, assumindo que é verdadeira a informação de que o acordo prevê o pagamento diferenciado aos cubanos, suprimindo-lhes do valor da

243 Informações publicadas no site de notícias Agência Brasil, disponíveis em: <http://agenciabrasil.ebc.com.br/noticia/2013-08-28/dilma-critica-preconceito-contra-cubanos>. Acesso em: 3 out. 2013. 
bolsa o equivalente a cerca de $\mathrm{R} \$ 6.000,00$ repassados ao governo de Cuba, o ajuste é inconstitucional.

Segundo o jurista, qualquer arranjo que resulte em pagamento de remuneração distinta entre os médicos cubanos e os demais participantes do programa "Mais Médicos" fere o art. 7. $^{\circ}$, inciso XXX, da Constituição Federal, que, ao tratar dos direitos dos trabalhadores urbanos e rurais, proíbe a diferença de salários, de exercício de funções e de critérios de admissão por motivos de sexo, cor, ou estado civil. ${ }^{244}$

A relação jurídica entre os médicos migrantes e o Governo brasileiro também mereceu parecer da Ordem dos Advogados do Brasil, Secção do Ceará, sob o título "Contratação de Médicos Estrangeiros no Brasil", apontando que, se tais profissionais não exercerão atividade sujeita às regras do art. $7^{\circ}$ da Constituição Federal, sob vínculo empregatício com entidade privada, a rigor, por exclusão, prestariam serviços na condição de funcionários públicos do Governo brasileiro.

Nesse ponto, o parecer os coloca sob o manto do art. 37, II, da Constituição Federal, a exigir dos profissionais em questão a investidura no cargo ou emprego público mediante prévia aprovação em concurso público de provas e títulos, colocando, assim, mais um entrave para que os médicos estrangeiros objeto do programa "Mais Médicos" possam ser admitidos no País. ${ }^{245}$

Não resta dúvida de que qualquer regra que diferencie profissionais estrangeiros entre si fere o princípio da igualdade e da ética nas políticas migratórias, na linha do que expusemos no Capítulo 1 do presente estudo.

Não obstante um pequeno reparo às considerações de Gandra, na medida em que os direitos assegurados no art. $7 .^{\circ}$ da Constituição Federal (reconhecimento de vínculo, salário profissional, férias, décimo terceiro, FGTS, jornada máxima de 44 ou inferior

244 Íntegra da entrevista concedida pelo Dr. Ives Gandra da Silva Martins ao sítio de notícias jurídicas Consultor Jurídico está disponível em: <http://www.conjur.com.br/2013-ago-27/contrato-medicoscubanos-ilegal-ives-gandra-martins $>$. Acesso em: 3 out. 2013.

245 Inteiro teor do Parecer sobre a contratação de médicos estrangeiros no Brasil está disponível em: <http://oabce.org.br/wp-content/uploads/d2103/07/Parecer_CS_contratacao_medicos_cubanos.pdf $>$. Acesso em: 3 out. 2013. 
conforme a profissão, horas extras, aviso prévio, verbas rescisórias proporcionais ao tempo trabalhado, entre outras) de toda forma não alcançariam os médicos estrangeiros, posto que restritos aos trabalhadores (brasileiros ou estrangeiros) submetidos a um vínculo empregatício.

Essa não é a situação jurídico-trabalhista à qual os profissionais estarão submetidos, e por isso o autor está corretíssimo ao apontar a existência de um critério discriminatório nas regras da bolsa concedida aos migrantes cubanos, quando comparado aos migrantes de outras nacionalidades, submetidos ao mesmo programa e que não se justifica sob nenhuma hipótese.

Tratando-se de serviço prestado ao Governo brasileiro, e à luz dos instrumentos internacionais estudados no Capítulo 1, temos que no mínimo os médicos de nacionalidade cubana deveriam aqui ingressar e permanecer sob idênticas condições oferecidas aos demais médicos estrangeiros.

Quanto aos direitos trabalhistas, como vimos, há uma enorme restrição que advém de nosso atual Estatuto e das próprias Resoluções expedidas pelo CNIg e que comumente restringem o acesso de determinadas categorias de profissionais ao vínculo empregatício, a exemplo dos técnicos estrangeiros sobre os quais explanamos no início deste tópico.

\subsubsection{Modalidades de vínculos trabalhistas}

Antes de adentrarmos nas questões controvertidas peculiares às relações jurídicas que se estabelecem entre trabalhadores migrantes e empresários, sob uma roupagem de vínculo empregatício e todos os direitos e deveres decorrentes dessa modalidade clássica de relação contratual, é necessário ressaltar que o trabalho do migrante pode ser prestado de várias maneiras. 


\subsubsection{Migrantes de baixa qualificação}

Na maioria das vezes por falta de opção, o migrante de baixa qualificação e escolaridade que for bem-sucedido no complexo e moroso processo de regularização de sua situação migratória, exercerá ocupações na condição de autônomo.

Um exemplo que será cada vez muito comum, sobretudo agora na vigência do Acordo de Residência do Mercosul, que permite o livre trânsito de todo cidadão nacional dos países-membros ou signatários dos acordos bilaterais avençados com o Brasil, serão os serviços domésticos e autônomos nas relações que se estabelecem entre as chamadas diaristas, jardineiros, entre outros afazeres domésticos com contratantes, na sua maioria pessoas físicas.

A relação que se estabelece entre esses profissionais e os contratantes de seus serviços raramente se desenvolve sob os elementos do vínculo empregatício clássico.

No entanto, nem sempre estaremos diante de uma situação de vitimização do trabalhador migrante de baixa qualificação. Na verdade, repudiamos essa forma de pensar que sempre coloca o migrante na condição de vítima ou de herói.

Não estamos aqui defendendo irregularidade de nenhuma espécie, apenas constatamos que falta um olhar sobre a migração de baixa qualificação, com respeito ao migrante como profissional que é.

O profissional conhecido como "diarista” em geral cobra $\mathrm{R} \$ 100,00$ ao dia valores praticados na cidade de São Paulo (SP), no ano de 2013 - para realizar a limpeza de uma residência. Assim, ao final de cinco dias, terá alcançado a quantia de $\mathrm{R} \$ 500,00$. Ao final de um mês, supondo que tenha conseguido trabalhar 15 dias úteis, alcançará o equivalente a $\mathrm{R} \$ 1.500,00$. Se contribuir com a Previdência Social brasileira, na categoria de contribuinte individual, recolherá a quantia de $\mathrm{R} \$ 120,00$, conforme previsto na tabela 
de contribuição mensal da previdência social, equivalente a $8 \%$, receberá um valor líquido de $\mathrm{R} \$ 1.380,00 .^{246}$

O mesmo trabalhador migrante, de baixa qualificação e escolaridade, em situação migratória regular poderia ser contratado sob vínculo empregatício mediante retribuição equivalente ao salário mínimo nacional, que em 2013 correspondia a R\$ 678,00. A esse valor se acrescem o Décimo Terceiro Salário e as Férias anuais acrescidas de $1 / 3$, que na proporção mensal elevarão esse valor para $\mathrm{R} \$ 753,14$. Sobre esse subtotal incidirá contribuição à previdência social mensal, no percentual de $8 \%$, resultando no salário líquido de $\mathrm{R} \$$ 692,89. O migrante terá direito aos depósitos para o FGTS, na proporção de $8 \%$, porém o saque, acrescido da multa de $40 \%$ (o empregador paga $50 \%$, porém $10 \%$ equivalem à contribuição social destinada ao governo), só é permitido em situações restritas, que abrangem a rescisão sem justa causa por iniciativa do empregador, a compra de casa própria, a aposentadoria e doenças graves.

A diferença matemática para o trabalhador migrante de baixa qualificação, exercendo ocupações na condição de autônomo, é positiva em $\mathrm{R} \$ 687,11$.

Reconhecemos que a conta é simplista e evidentemente não leva em conta que as empresas normalmente remuneram acima do salário mínimo nacional, o que poderia elevar a remuneração líquida para cera de $\mathrm{R} \$ 1.000$, nem as vicissitudes maiores que um trabalhador autônomo enfrentará em sua lida diária, nem o fator de segurança que o vínculo empregatício promove, com o acesso à representação sindical (esta mediante o desconto anual do empregado do valor equivalente a um dia de trabalho), reajustes salariais anuais, vale-transporte e eventualmente o acesso a benefícios adicionais, não obrigatórios, como o vale-refeição e plano de saúde privado, com o custo subsidiado pelo empregador.

O exercício, porém, nos parece válido para repensarmos sobre as várias maneiras de se trabalhar, procurando respeitar o indivíduo, tratando-o como um profissional.

246 Disponível em: <http://www.previdencia.gov.br/tabela-de-contribuição-mensal>. Acesso em: 3 out. 2013. 
Nessa linha, a mídia tem noticiado a busca de especialização por parte de profissionais autônomos de serviços de limpeza, os conhecidos "diaristas", na expectativa de suprir um mercado constituído de residências de família de classe média, que poderá valorizar o exercício dessa ocupação. Reconhecida empresa de recolocação profissional já oferece cursos de qualificação para diaristas que possuam escolaridade equivalente ao Ensino Fundamental completo, com conteúdo que inclui cuidados do vestuário, administração da casa, arrumação, cuidados com plantas e animais domésticos. ${ }^{247}$

Nessa perspectiva, a melhor forma de promover mudanças positivas na situação aos migrantes de baixa qualificação é a informação clara e precisa sobre seus direitos, a integração do migrante na sociedade, nos serviços de assistência profissional, social e de saúde, a promoção de cursos de formação educacional, enfim, promover a integração gradual e contínua do estrangeiro em nossa sociedade.

Outros vínculos trabalhistas poderiam ser cogitados, contudo há que se sopesar a tradição brasileira voltada à relação empregatícia clássica. Nesse sentido, Otávio Pinto e Silva explica que, apesar de o direito do trabalho adotar o critério da subordinação como um dos critérios usados para identificar "o contrato de trabalho apto a receber a tutela jurídica do direito do trabalho", devemos levar em conta "outras relações de trabalho em que a subordinação também está presente". ${ }^{248}$

Trata-se da parassubordinação, noção desenvolvida pela doutrina italiana, que reconhece a existência de determinadas relações em que o trabalhador poderá desenvolver atividades que se enquadram nas necessidades empresarias, mas, em vez de se configurarem uma relação clássica empregatícia, constituem um vínculo que não se confunde com o trabalho subordinado clássico. Poderão apresentar características próprias que a afastarão do típico vínculo empregatício. ${ }^{249}$

A ideia de coordenação por parte do tomador dos serviços realizados pelo trabalhador migrante, em vez de uma situação de subordinação, é ainda nova no Brasil, e

\footnotetext{
247 Disponível em: 〈http://www3.catho.com.br/guia/view.php?id=741〉.

248 Otávio Pinto e Silva. Subordinação, autonomia e parassubordinação nas relações de trabalho. São Paulo: LTr, 2004. p. 14.

249 Otávio Pinto e Silva. Subordinação, autonomia e parassubordinação nas relações de trabalho, p. 46.
} 
assim a noção de parassubordinação, defendida por Otávio Pinto e Silva, inspirado pelo direito italiano, poderia ser bastante útil para uma visão moderna e necessária perante a globalização e a constante necessidade de reorganização das empresas pós-fordistas do século XXI. ${ }^{250}$

O conceito da parassubordinação se amoldaria muito bem às contratações de média qualificação de migrantes altamente qualificados cujo ingresso no Brasil é extremamente limitado, tanto em termos de vínculos jurídicos locais quanto em período máximo de estadia permitido. Os técnicos especializados, por exemplo, têm o seu ingresso vinculado ao pagamento de salários no exterior, sendo vedada a sua contratação sob vínculo empregatício local.

\subsubsection{Migrante qualificado}

Em outro patamar econômico encontra-se o migrante qualificado, geralmente transferido de uma unidade empresarial para um período de dois a três anos no exterior, para o exercício de cargos de gestão na unidade local. Ele terá acesso apenas ao vínculo empregatício clássico, sendo comum estabelecerem-se transferências intraempresas sob vínculos de natureza civil, casos dos diretores estatutários de sociedades anônimas e administradores de empresas limitadas.

Tratando-se a empresa contratante de Sociedade Anônima, a Lei n. 6.404/1976 dispõe em seu art. 138 que: "A administração da companhia competirá, conforme dispuser o estatuto, ao Conselho de Administração e à Diretoria, ou somente à Diretoria”.

Dessa forma, conforme Adriana Calvo, a legislação admite "dois tipos de administradores: o conselheiro (administrador patrimonial) e o diretor (administrador profissional)", tipo em que poderá o trabalhador migrante se enquadrar, na condição diretor não empregado, eleito como diretor por assembleia de acionistas. ${ }^{251}$

\footnotetext{
250 Idem, ibidem, p. 194.

251 Adriana Calvo, Diretor de sociedade anônima: patrão - empregado?, p. 23.
} 
Quando o migrante é contratado ou transferido intraempresas para assumir posição com poderes de gestão, sob a RN n. 62/2004 do CNIg, poderá ser designado empregado, hipótese em que estará sob a proteção da legislação trabalhista, ou ocupar cargo de diretor ou conselheiro, por indicação da assembleia de acionistas e, em tese, nessa hipótese não se aplicar a proteção do Direito do Trabalho, enquanto o diretor permanecer no cargo.

A condição de diretor não empregado se configura com base na realidade dos serviços e na forma e condições pelas quais é prestado na prática. Assim, quando permanecem as mesmas características típicas da relação de emprego, a doutrina e a jurisprudência entendem se tratar de fraude e garantem a aplicação de todos os direitos trabalhistas atrás mencionados.

Na prática, a análise da situação do empregado eleito ao cargo de diretor tem se orientado pelo elemento da subordinação, significando que na relação entre empregado e empregador é esse quem dita as normas, quem dirige a atividade econômica. Assim, se persistirem, na realidade, as mesmas funções que o empregado exercia antes de ser eleito diretor estatutário, continuando a desempenhá-las nas mesmas condições, sob a denominação de "diretor", mas sem poderes de mando e gestão, a Justiça reconhece a subordinação e os direitos assegurados ao empregado escolhido.

Nesse sentido, a Súmula n. 269 do C. TST considera suspenso o contrato de trabalho do empregado, que em dado momento da relação empregatícia é eleito para cargo de direção, exceto nos casos em que prevaleça a subordinação jurídica inerente à relação de emprego.

Na mesma linha, a Lei n. 8.213/1991, que dispõe sobre os Planos de Custeio da Previdência Social, estatui que:

Considera-se diretor empregado aquele que, participando ou não do risco econômico do empreendimento, seja contratado ou promovido para cargo de direção das sociedades anônimas, mantendo as características inerentes à relação de emprego.

Do exposto, o diretor não empregado deve possuir efetivamente poderes de mando e gestão na empresa, de modo a diferenciar a relação jurídica que passou a existir 
entre as partes com a eleição daquela anteriormente existente e que era de natureza empregatícia.

No que se refere ao FGTS, conforme o art. 16 da Lei n. 8.036/1990, pode a empresa, facultativamente, efetuar o recolhimento de $8 \%$ sobre as retiradas do diretor não empregado. É a redação deste dispositivo:

Art. 16. Para efeito desta lei, as empresas sujeitas ao regime da legislação trabalhista poderão equiparar seus diretores não empregados aos demais trabalhadores sujeitos ao regime do FGTS. Considera-se diretor aquele que exerça cargo de administração previsto em lei, estatuto ou contrato social, independente da denominação do cargo.

Hipótese semelhante poderá ocorrer na contratação ou transferência de trabalhador migrante qualificado sob a autorização de trabalho da $\mathrm{RN}$ n. 62/2004, para o exercício do cargo de administrador de sociedade limitada. A partir do Novo Código Civil, de 10.01.2002, abriu-se a possibilidade de a administração das sociedades limitadas ser feita por não sócios, desde que conste tal disposição no contrato social (art. 1.061). Com isso, criou-se no nosso ordenamento jurídico a figura contratual do Administrador de Sociedades Limitadas Não Sócio.

A hipótese do Administrador Não Sócio e Não Empregado foi também chancelada pela norma previdenciária quando do surgimento do Decreto n. 4.729/2003, de 09.06.2003, que admitiu a figura do Administrador Não Empregado, enquadrando-o como contribuinte individual, e apartando-o da figura do empregado.

\subsection{Direitos trabalhistas versus proteção ao mercado nacional}

\subsubsection{Obtenção de documentos de identificação}

Com o visto de ingresso e autorização de trabalho devidamente concedidos, o migrante, cujo processo de migração se dará sob vínculo de emprego, fica responsável por manejar os protocolos e registros anteriores e só está apto para obter a CTPS mediante a apresentação da Cédula ou do protocolo de solicitação da Cédula de Identidade do Estrangeiro, que como vimos anteriormente é competência da Polícia Federal. 
Além disso, é necessário realizar o registro no Sistema Nacional de Cadastramento de Registro de Estrangeiro (Sincre). Como não há nenhuma interação entre os órgãos que permita o trânsito automático dessas informações, assim como não existe uma coordenação de prazos de modo a tornar o processo mais ágil, o processo é moroso e confuso.

Nesse ato de obtenção da CTPS, o migrante será identificado como estrangeiro, pois as folhas destinadas às anotações do contrato de trabalho exigem o número do documento da Cédula de Identidade do Estrangeiro. Essa orientação é corroborada pelo art. 359 da CLT, que dispõe sobre a proibição de contratação de empregado estrangeiro sem que este exiba a carteira de estrangeiro.

\subsubsection{Proteção do mercado de trabalho nacional}

Um dos temas mais polêmicos relacionados à condição trabalhista do migrante é a chamada "regra dos $2 / 3$ ".

Os arts. 352, caput, e 354, caput e parágrafo único, da CLT dispõem sobre a obrigatoriedade das empresas de manter no quadro de pessoal, quando composto de três ou mais empregados, uma proporção de $2 / 3$ de empregados brasileiros, que não será apenas em relação à totalidade do quadro de empregados, como também no tocante à correspondente folha de salários.

O texto do art. 354 admite a possibilidade de ser fixada uma proporcionalidade inferior, porém mediante a comprovação de insuficiência de brasileiros para a atividade. A comprovação, contudo, envolve um procedimento complexo que passa por ato do Poder Executivo, apurada pelo Ministério do Trabalho e Emprego e pelo Serviço de Estatística da Previdência.

Conforme o art. 357 e o art. 352, $\S 2 .^{\circ}$, não se compreendem na regra de proporcionalidade os empregados contratados para o exercício de funções técnicas especializadas, desde que, a critério do Ministério do Trabalho e Emprego, mediante as Resoluções do CNIg, se trate de segmento econômico com falta de trabalhadores nacionais. 
Tampouco aplica-se a proporcionalidade às indústrias rurais cuja atividade se destine ao beneficiamento ou transformação de produtos da região e atividades industriais de natureza extrativa, exceto a mineração.

Lopes ressalta casos em que os estrangeiros estão isentos da regra da proporcionalidade: a) estrangeiros residentes no País há mais de dez anos, desde que tenham cônjuge ou filho brasileiro; b) portugueses (ambos equiparados aos brasileiros); e c) empregados que exerçam funções técnicas especializadas, nas quais há comprovada falta de trabalhadores nacionais. ${ }^{252}$

Entretanto, em nossa atividade profissional, defrontamo-nos com casos concretos em que a proporcionalidade foi exigida para concessão de autorização de trabalho, inclusive para cidadãos portugueses, não obstante a expressa exclusão de tal critério em relação a esses estrangeiros.

A doutrina se divide entre a corrente que entende derrogada a regra da proporcionalidade, desde a promulgação da Constituição Federal de 1988, à medida que confronta com o princípio antidiscriminatório em relação ao estrangeiro ${ }^{253}$ e a corrente que defende que o art. 352 da CLT foi recepcionado pela CF/1988. ${ }^{254}$

A polêmica sobre esse sistema que se assemelha ao de cotas humanas, muito utilizado nos países desenvolvidos, decorre da sua incompatibilidade com a Constituição Federal brasileira e com a própria Lei n. 6.815/1980 - Estatuto do Estrangeiro, que a rigor não admite a discriminação entre nacionais e estrangeiros.

Nesse sentido, Maristela Basso destaca que são elementares os direitos reconhecidos no sistema jurídico nacional sobre o direito dos estrangeiros à igual proteção

252 Cristiane Maria Sbalqueiro Lopes, Direito de imigração: o Estatuto do Estrangeiro em uma perspectiva de direitos humanos, p. 591.

253 Dentre os defensores da derrogação da regra da proporcionalidade, citamos Mauricio Godinho Delgado, Curso de direito do trabalho, p. 779, e Valentim Carrion, Comentários à CLT, p. 250.

254 Cristiane Maria Sbalqueiro Lopes, Direito de imigração: o Estatuto do Estrangeiro em uma perspectiva de direitos humanos, p. 592-593, defende que o primeiro acesso do estrangeiro ao mercado brasileiro pode ser controlado, como forma de proteger o mercado de trabalho brasileiro como um todo, de oscilações e distorções que podem ser provocadas por empresários que descumprem normas trabalhistas e tributárias e que o critério não se constitui em impeditivo à ampla margem de discricionariedade na contratação de estrangeiros. 
em nosso território e a proibição de imposição de cotas humanas. Ao se manifestar sobre os migrantes ilegais, a exemplo dos haitianos, a autora denuncia que os funcionários do Governo "dão de ombros aos compromissos internacionais" e descumprem ou desconhecem a própria legislação brasileira. ${ }^{255}$

Lima entende que a regra da proporcionalidade é "completamente anacrônica", um resquício de um tempo em que o Brasil iniciava sua industrialização, simultaneamente a um regime militar totalitarista, em que de um lado era necessária a contratação de mão de obra especializada suprida por estrangeiros e, por outro lado, temia-se que a falta de controle sobre esse contingente de trabalhadores poderia pôr em risco a segurança nacional, por ataques que poderiam advir de atividades subversivas. ${ }^{256}$

A nosso ver, o sistema de proporcionalidade não difere significativamente do sistema de cotas adotados pelos países desenvolvidos como uma forma de controle gradual do fluxo de migrantes.

A proporcionalidade limita sim o direito de ingresso do estrangeiro ao mercado de trabalho, porém nos parece exagerado defender a sua plena extinção. Pensamos que o critério poderia ser mais bem sopesado pela via dos acordos bilaterais entre países de origem e de destino dos trabalhadores migrantes, fórum adequado para a discussão de critérios de ingresso versus reciprocidade entre os países, com a natural flexibilização entre as partes envolvidas, em prol do bem comum.

O sistema de cotas anuais poderia, inclusive, propiciar o ingresso de um determinado número de migrantes de baixa qualificação, que hoje não existe nas regras de migração do Brasil. Nesse sentido, um caminho a ser estudado seria a substituição da regra dos 2/3 que afeta diretamente a empresa considerada individualmente, para um sistema de quotas anual geral. A ideia não é nova, eis que praticada em muitos países da UE e inclusive nos Estados Unidos, de modo a permitir o ingresso controlado de determinado número de migrantes com ou sem qualificação. Evidentemente, esse sistema necessita ser

\footnotetext{
255 Maristela Basso, O Brasil pratica ato ilegal e imoral contra os haitianos. Disponível em: <www.migalhas.com.br>. Acesso em: 2 mar. 2013.

256 A. Lima, Brasileiros na América, p. 294.
} 
amplamente discutido em fóruns internacionais, mas é sem dúvida um critério mais benéfico ao migrante do que a regra atual.

Outra regra de proteção ao mercado de trabalho brasileiro se repete no art. 358, no que consideramos justa a estabelecer a proibição de pagamento de salário inferior ao estrangeiro que exercer função análoga, excetuando-se os casos em que o estabelecimento: a) não possuir quadro de empregados organizados em carreira, e o brasileiro contar com menos de dois anos de serviço e o estrangeiro, com mais de dois anos; b) quando houver quadro organizado em carreira aprovado pelo Ministério do Trabalho e Emprego, em que seja garantido o acesso por antiguidade; e) quando o brasileiro for aprendiz, ajudante ou servente, e não o for o estrangeiro; d) quando a remuneração resultar de maior produção, para os que trabalham à comissão ou por tarefa. Finalmente, demonstrando claramente uma desigualdade de oportunidades ao estrangeiro, o parágrafo único do art. 358 prevê que, nos casos de falta ou cessação de serviço, a dispensa do empregado estrangeiro deve preceder à de brasileiro que exerça função análoga.

A fiscalização do atendimento das regras supracitadas se faz mediante a apresentação da Relação Anual de Empregados, prevista no art. 360, caput e $\S 1 .^{\circ}$, que deverá ser apresentada anualmente ao Ministério do Trabalho e Emprego, no período de 2 de maio a 30 de junho, segundo o modelo que for expedido.

As infrações às regras dispostas nos arts. 363 e 364 sujeitam as empresas à multa de seis a seiscentos valores de referência regionais, conforme as regras dos arts. 626 e 638 .

\subsection{Migrações intraempresariais}

As migrações intraempresariais usualmente objetivam deslocar indivíduos altamente qualificados dos países mais desenvolvidos para outros mais pobres, no movimento a que nos referimos no Capítulo 1 caracterizado pelo brain drain, com consequências desfavoráveis para os países de origem, que não são compensados por eventuais remessas financeiras ou transferências de tecnologia geradas em contrapartida. 
No entanto, com o aquecimento da economia e a maior internacionalização das empresas brasileiras, o deslocamento, a nosso ver, poderá abranger o fenômeno do brain gain, uma vez que trabalhadores locais também são transferidos para economias desenvolvidas, compartilhando conhecimento que produz efeitos positivos a ambos os países, de origem e de destino.

Evidentemente que o deslocamento de trabalhadores internacionalmente sujeita-se a cultura e estrutura organizacional específica da empresa. Segundo Peixoto, o fluxo tradicionalmente envolve os recursos humanos mais qualificados que "se movimentam numa rede constituída por vários estabelecimentos mundiais da empresa", e a maioria desses profissionais "móveis" é da mesma nacionalidade do país de origem da empresa. $^{257}$

Estudiosos do tema apresentam um conjunto de razões pelas quais as empresas transnacionais operam a transferência de profissionais de seu mercado interno de trabalho especializado, às quais acrescentamos nossa visão, adquirida durante a interação profissional com empresas transnacionais:

i. Necessidade de preencher vagas específicas, que não são oferecidas adequadamente no país de destino.

ii. Aproveitamento de qualidades individuais de gestão de um empregado local, que podem ser mais bem utilizadas em outro local.

iii. Aquisição de experiência internacional como forma de aprimorar a formação do profissional sobre a própria empresa.

Compreendido o contexto econômico em que se inserem as transferências intraempresas, faz-se necessário analisar como se realizam e se desenvolvem as relações jurídico-trabalhistas entre esses profissionais e as respectivas empresas em que atuam.

257 J. Peixoto, A mobilidade internacional dos quadros, p. 69. 


\subsubsection{Lei de regência do contrato}

No Brasil, há muito tempo se trava um acirrado debate doutrinário e jurisprudencial sobre a liberdade de os contratantes decidirem, em um contrato de trabalho, qual a lei (nacional ou estrangeira) que regerá os direitos e obrigações.

A dificuldade decorre da multiplicidade de relações jurídicas que se desenvolvem sob arrasto do incremento da circulação de trabalhadores para todas as partes do mundo, com ou sem vínculo empregatício. Os estudos contemplam, exemplificativamente:

a) Migração itinerante: que trata das relações constituídas sob vínculo empregatício no Brasil, que desenvolvem simultaneamente, no plano nacional e internacional. Amauri Mascaro Nascimento identifica a ocorrência da migração itinerante mediante análise do contrato firmado entre as partes. Quando o deslocamento entre territórios de diferentes países é uma condição contratual, entende Mascaro a coexistência de condições e regras que se sujeitam ao ordenamento jurídico de um e outro Estado. ${ }^{258}$

b) Transferências provisórias: assim definidas porque se referem às relações constituídas no estrangeiro, seguidas de transferências provisórias do trabalhador para o Brasil para prestar serviços ao mesmo empregador ou empresa que com este constitua grupo econômico; relações constituídas no Brasil, seguidas de transferência do trabalhador para o estrangeiro;

c) Transferências definitivas: o caráter definitivo de uma transferência tanto poderá ser definido no ato da transferência do trabalhador migrante para a prestação de serviços em outro país quanto assim se caracterizar pela redefinição de provisória em permanente no curso do período da transferência internacional.

Questões de natureza teórica e prática incidem de forma não linear nessas hipóteses, contaminando de insegurança jurídica os migrantes de modo geral, além de

258 Amauri Mascaro Nascimento, Teoria geral do direito do trabalho, p. 211. 
tornar extremamente difícil às partes (migrantes e empregadores) compreender a lei de regência do contrato, as repercussões decorrentes do princípio da unicidade do contrato, a caracterização e efeitos do grupo econômico, os limites das alterações contratuais no âmbito de um contrato único e, inclusive, as dificuldades de rescisão de um contrato local.

A seguir, procuramos destacar questões que comumente ensejam conflitos e insegurança jurídica para as partes contratantes, sobretudo quando se estabelece um vínculo empregatício entre as partes e esse vínculo se desenvolve em solo brasileiro.

A tensão que se estabelece entre a aplicação da lei do local da contratação ou da lei do local da execução dos contratos decorre do fato de que, diferente da liberdade de escolha da lei aplicável aos contratos que predomina na UE, ${ }^{259}$ no Brasil as partes, quando celebram um contrato, em geral se submetem preponderantemente às normas do art. $9 .^{\circ}$ da Lei de Introdução às Normas do Direito Brasileiro. De acordo com a Lei n. 4.656, de 04.09.1942, com alteração da Lei n. 12.376, de 30.12.2011, a LINDB, em seu art. 9. ${ }^{\circ}$ as obrigações serão qualificadas e regidas pela aplicação da "lei do país em que se constituírem".

259 Interesse e conteúdo da Convenção de Roma. A Convenção de Roma (Disponível em: <http://eurlex.europa.eulLexUriServlLexServ.do:uri=CELEX;41998A0126(02):pt:N>. Acesso em: 1. ${ }^{\circ}$ out. 2013) entrou em vigor em $1{ }^{\circ} .04 .1991$, como um instrumento de uniformização do Direito Internacional Privado entre os países da UE.

Em apertada síntese, pode-se dizer que as normas desta Convenção objetivam regular apenas situações onde houver a necessidade de aplicação das normas do Direito Internacional Privado. Assim, o art. 1. $^{\circ}, \mathrm{n}$. 2, excepciona a aplicação da Convenção quando os contratos envolverem conflitos decorrentes do estado e da capacidade das partes.

A Convenção visa conferir às partes em um contrato a liberdade de escolha da lei aplicável para reger os direitos e as obrigações, no todo ou em parte, na forma que constar do documento ou contrato assinado pelas partes. As regras valorizam, como ressalta Costa, o princípio da liberdade contratual das partes na sua essência, contudo apresenta como ponto negativo, o fato de que, a depender dos sujeitos envolvidos na relação contratual, há riscos de validade do que for celebrado. Nesse sentido, Adalberto pontua que o art. 5. ${ }^{\circ}$ da Convenção determina a aplicação da lei reguladora do país em que o consumidor tem a sua residência habitual. Assim, "se o contrato for celebrado à luz da Convenção de Roma, entre partes que se encontrem no mesmo país, esse contrato é formalmente válido, se respeitar os requisitos de forma que são prescritos pela lei que regula o aspecto de substância do contrato nos termos da Convenção e ou então pela lei do país em que o contrato foi celebrado". Contudo, se os sujeitos do contrato se encontram em países diferentes, aplicar-se-á a lei prevista na Convenção ou a lei de qualquer um dos países onde se encontram as partes (Adalberto Costa, A lei aplicável às obrigações contratuais. Disponível em: 〈http://www. Regisconsultorum.pt|contributos.htm〉. Acesso em: 1. ${ }^{\circ}$ out. 2013).

É possível, assim, identificar que o critério principal da Convenção de Roma é a autonomia das partes, mas, como pondera Antonio Galvão Peres (Contrato internacional de trabalho: acesso à justiça conflitos de jurisdição e outras questões processuais, p. 72), "uma autonomia com limites", de modo a prevenir o enfraquecimento da proteção devida ao trabalhador. 
Pela aplicação do art. 9..$^{\circ}$ da LINDC, teríamos que, para qualificar e reger as obrigações, o elemento de conexão seria a lei do país em que as obrigações tivessem sido constituídas.

Exemplificativamente, um empregado contratado nos Estados Unidos, que posteriormente tivesse migrado para o Brasil, sob um programa de transferência internacional, para prestar serviços para empresa integrante do mesmo grupo econômico daquela sediada no país de origem do migrante, teria sua situação regulada pela lei dos Estados Unidos.

O contrato internacional assim se qualifica, nessa hipótese, diante da existência de um ou mais elementos estrangeiros, tais como a nacionalidade das partes, seu domicílio, o local da celebração do contrato ou de sua execução, a moeda na qual é fixada a remuneração do empregado, entre outros.

A relação que se estabelece nesse contexto requer considerar que a diversidade de sistemas legislativos e os desníveis no desenvolvimento econômico são aspectos que levam ao enfoque da aplicação da norma mais favorável ao empregado transferido ao exterior.

Apesar do considerável esforço da Organização Internacional do Trabalho em elaborar normas comuns em matéria de proteção social aos trabalhadores durante a mobilidade internacional, a diversidade de regras jurídicas e de condições de trabalho não permitiu produzir mais do que princípios gerais de promoção da legislação.

O princípio da territorialidade atua como um dos principais elementos para a definição a lei competente para regular um contrato de trabalho. Esse princípio foi consignado na Convenção de Havana, de 1928, ratificada pelo Brasil, prevista no art. 198 do Código de Bustamante e consagrada pela jurisprudência do Tribunal Superior do Trabalho (TST), na Súmula n. 207, esta cancelada por ato aprovado pelo Pleno do TST em 16.04.2012.

Arion Sayão Romita destaca que o princípio da territorialidade remonta à Idade Média, época em que o significado latino da palavra estava mais ligado à ideia de "afastar, 
apartar, arredar, repelir, espantar, afugentar e expulsar". Nessa linha, chega-se ao objetivo da territorialidade que, segundo o autor, estaria ligado à ideia de aplicar a lei nos limites da sua jurisdição, afastando ou repelindo a interferência alheia. ${ }^{260}$

É dizer que na apreciação de um contrato de trabalho realizado no estrangeiro por tribunais brasileiros ainda prevalece a regra que repousa em três fontes principais: a) a aplicação das normas trabalhistas brasileiras, posto que são de ordem pública; b) a aplicação da lei do local do trabalho, na medida em que protege o trabalhador; c) a aplicação da lei do local de trabalho como forma de assegurar igualdade de tratamento entre brasileiros e migrantes; e d) a orientação pela aplicação da lei mais benéfica ao trabalhador.

Os traços de extraterritorialidade, contudo, dão margem a uma variedade enorme de conflitos, e a identificação da lei de regência resulta em tarefa das mais difíceis, à vista da enorme variedade de relações jurídicas que se estabelecem no tempo e no espaço, envolvendo os vínculos que ligam um nacional ou estrangeiro a uma pessoa jurídica, nacional ou estrangeira.

No que diz respeito ao território, como destaca Cassar, "a legislação deve regular todas as relações de emprego surgidas no território nacional (art. 1. ${ }^{\circ}$, parágrafo único, CLT)", uma vez que a CLT vigora em todo o País. ${ }^{261}$

Quanto às leis no tempo, a autora enfatiza que "têm aplicação imediata e atingem os contratos de trabalho em curso, mas não modificam os já extintos”.

No espaço, Cassar destaca o contrato de trabalho, como um contrato de trato sucessivo, de tal forma que poderá o empregado ser contratado em determinado país, sendo transferido posteriormente para prestar serviços em um outro país ou, ainda, ter no início avençado a sua contratação com o objetivo de prestar serviços em sistema de rodízio, ou, como denomina Mascaro, na condição de itinerante.

\footnotetext{
260 Arion Sayão Romita, Prestação de serviços no exterior. Conflito de leis no espaço, p. 8.

261 Vólia Bomfim Cassar, Aplicação do direito do trabalho no território, no tempo e no espaço, p. 11781179.
} 
Não raro, surgirão dúvidas sobre a legislação trabalhista aplicável a essa relação: o conflito será entre a lei do local de origem do trabalhador, ou a do local de destino, ou, ainda, uma combinação de direitos previstos em ambas as legislações, prevalecendo a lei mais benéfica.

Quanto à dúvida ou conflito de lei no espaço, Husek ensina que o Direito Internacional Privado oferece solução pela determinação da “Lex fori (lei do foro), que ora aponta a lei estrangeira, ora a lei nacional. Tal acontece porque o conflito existe: em um mesmo caso, duas ou mais ordens jurídicas podem incidir e o nosso Direito Internacional Privado esclarece qual delas deverá ser a preferida. Daí porque esse ramo do Direito é chamado de instrumental, indicativo, indireto, meramente técnico, porquanto ele não dá solução para o caso concreto, ele apenas aponta onde deve ser encontrada a solução."262

A corrente doutrinária predominante caminhava no sentido da aplicação do princípio da territorialidade, em grande parte norteado pela necessidade de se criar uma rede de proteção do trabalhador nacional diante do estrangeiro, somente mitigada em hipóteses restritas. Uma dessas hipóteses é colocada por Amauri Mascaro Nascimento:

Atuando dois estrangeiros, pessoa jurídica e pessoa física empregado, mantivessem uma relação de trabalho contratada no seu país para ser desenvolvida em outro, de modo que o Direito do Trabalho não rejeita a autonomia da vontade e o pacta sunt servanda, ajustando-o ao princípio da territorialidade, para que este venha a ser a regra determinante da proteção mínima a ser observada, por estrangeiros, em outro país, sem prejuízo da pactuação de vantagens maiores, acima desses patamares mínimos fixados pelo ordenamento jurídico no espaço onde a relação de emprego é exercida. ${ }^{263}$

A posição de Mascaro sobre a predominância do princípio da territorialidade também se refletia na jurisprudência trabalhista, sedimentada a partir de 1985, com a edição da Súmula n. 207, pelo Tribunal Superior do Trabalho, que regulava conflitos interespaciais, definindo que a relação jurídica trabalhista se regia pelas "leis vigentes no país de prestação de serviço, e não por aquelas do local da contratação".

${ }^{262}$ Carlos Roberto Husek, Curso básico de direito internacional público e privado do trabalho, p. 163

263 Amauri Mascaro Nascimento, Teoria do direito do trabalho, p. 210-211. 
A regra da Súmula n. 207 partia do entendimento de que o art. 9. ${ }^{\circ}$ da lei em comento seria aplicável apenas aos negócios em geral, mas não ao contrato de trabalho, que continuaria sob o manto das regras dispostas no Código de Bustamante, ratificado pelo Brasil e promulgado pelo Decreto n. 18.871, de 13.08.1929, que no seu art. 198 dispõe que se aplica a lei do lugar da execução do contrato (lex loci executionis) para reger os direitos e obrigações do trabalhador migrante, contratado no exterior, durante o período em que prestar serviços no Brasil.

De fato, a aplicabilidade desta Súmula estava diretamente ligada ao fato de ter o trabalho sido realizado de forma permanente sempre no mesmo país, ou, de que a migração do trabalhador para outro país, que tivesse ocorrido em dado momento, igualmente se revestia de um caráter permanente.

Ocorre que nem sempre a situação se encaixa nesse formato. Há situações em que o trabalho é transitório, desenvolvido em diversos países. Cassar alerta que, não raro, o trabalhador continua vinculado a um estabelecimento da empresa, enquanto desenvolve o trabalho em diversos países, com ou sem residência fixada em cada um destes países. ${ }^{264}$

Exemplos dessa forma de prestação de serviços são os executivos encarregados do monitoramento dos negócios globais da empresa matriz, em diversos países. Nessas circunstâncias, a autora sugere a preponderância da lei do país onde o contrato normalmente é executado, ou do país em que se localiza o estabelecimento da matriz, ou, na falta dos parâmetros anteriores, a lei do país do estabelecimento ao qual o trabalhador se manteve vinculado durante a prestação dos serviços itinerantes.

A doutrina de Délio Maranhão confirma essa regra intermediária:

Questão interessante é a da aplicação do direito mais favorável ao trabalhador, no caso de conflito de leis. Concordamos com a opinião de Krotoschin, quando sustenta que a primazia do direito mais favorável deve limitar-se ao mesmo ordenamento jurídico, não sendo admissível sua extensão ao terreno internacional, porque, nessa hipótese, ver-se-ia o juiz, muitas vezes, ante a dificuldade, praticamente insuperável, de determinar qual dos ordenamentos, considerados em conjunto, é o "mais

264 Vólia Bomfim Cassar, Aplicação do direito do trabalho no território, no tempo e no espaço, p. 1179. 
favorável", já que não seria possível submeter uma só relação jurídica a direitos distintos. ${ }^{265}$

A regra intermediária proposta por Maranhão ainda deixa margem à insegurança jurídica para as partes, sobretudo quando o fenômeno da migração é, como chamaremos, uma migração triangular, ou seja, uma relação em que há um empregado originalmente contratado em seu país de residência que, em dado momento, é transferido para prestar serviços, o princípio da aplicação da lei do país da prestação de serviços, em princípio, continua válido.

A validade deve ser apenas para garantir ao migrante os direitos trabalhistas previstos na lei brasileira, durante o período de permanência no país sob vínculo empregatício, sem prejuízo dos direitos que eventualmente as partes tenham avençado para permanecer em vigor, no país de origem do migrante, durante o período de sua permanência no Brasil.

Nesse ponto, filiamo-nos ao entendimento de Amauri Mascaro Nascimento, no seguinte sentido:

A transferência de um empregado para outro país pelo mesmo empregador não é o mesmo que extinção do contrato. O contrato de trabalho é único. Os direitos por ele previstos são exigíveis. Inexigível é a extensão dos direitos previstos pela legislação do país para o qual o empregado foi transferido sobre o tempo prestado em outro país no qual a legislação ou o contrato não os assegurar. A lei de um Estado não se aplica em outro Estado, salvo se por este recepcionada ou pelo contrato definida. Para fins de antiguidade, estabelecidos pela legislação do local da contratação, soma-se o tempo de serviço do contrato único prestado em mais de um país. ${ }^{266}$

Como se vê, o princípio da lei do local da prestação dos serviços não é absoluto para todas as situações.

Situações como esta, em que um contrato iniciado no exterior, em dado momento, passou a se desenvolver no Brasil em caráter permanente, foram delineadas na jurisprudência trabalhista caso a caso.

\footnotetext{
265 Délio Maranhão, Instituições de direito do trabalho, p. 178.

266 Amauri Mascaro Nascimento, Teoria geral do direito do trabalho, p. 211.
} 
O Ministro Gelson de Azevedo entendeu, no caso em que determinado trabalhador fora contratado na Venezuela e lá trabalhou por certo tempo, que não se aplicaria o cômputo desse período de contrato ao restante do contrato desenvolvido no Brasil, consoante se confere do seguinte trecho do seguinte acórdão:

[...] b) a Súmula n. 207 foi contrariada: se a relação jurídico-trabalhista é regida pelas leis vigentes no país da prestação do serviço e esta se deu na Venezuela, não é possível estabelecer a accessio temporis em relação ao contrato nacional. Fosse possível, deveria ocorrer de forma plena, com o que poderíamos ter um ocupante de cargo de confiança trazido permanentemente ao Brasil, percebendo, necessariamente, o mesmo salário que the era alcançado em país com realidade socioeconômica completamente diversa. Assim, os dois princípios que fundamentam o acórdão regional servem, ao contrário do entendimento adotado no acórdão recorrido, justamente para repelir a pretensão do Reclamante, na espécie: as leis do local da prestação dos serviços e da prática do ato devem ser compreendidas nos limites dos respectivos países em que o trabalho se deu e os fatos ocorreram;

c) o art. 453 da CLT também foi violado, uma vez que nele não há previsão de cômputo de período de contrato de trabalho realizado no exterior. Mesmo que assim não fosse, ad argumentandum, porque no citado dispositivo legal não há expressa vedação ao cômputo em exame, certo é que sua interpretação não admite o elastecimento adotado pela Corte Regional: a norma impõe, à soma dos períodos de trabalho, excludentes específicos da legislação brasileira e cuja existência ou inexistência no estrangeiro é ignorada. E ainda que fosse conhecida, estaria restrita aos limites impostos na Súmula n. 207 (TST, 5. ${ }^{a}$ Turma, Processo RR 1907/1990-031-01-00, Rel. Min. Gelson de Azevedo, DJ 22.06.2007). ${ }^{267}$

Para as situações de provisoriedade da migração, muito mais comuns do que a migração permanente, sobretudo quando envolvem empregado de empresas multinacionais que operam em várias jurisdições, Arion Sayão Romita é favorável à aplicação da norma mais favorável, "o conflito de leis do trabalho é, hoje, resolvido pela aplicação da norma mais favorável ao trabalhador. a afirmação encontra apoio na lei e na doutrina". ${ }^{268}$

Peres, contudo, adverte que as situações em que o empregador cede ou transfere o empregado para outra empresa atraem o que chama de "migração entre

\footnotetext{
267 Disponível em <http://aplicacao5.tst.jus.br/consultaDocumento/acordao.do?anoProcInt=2006\& numProcInt=241491\&dtaPublicacaoStr=22/06/2007 00:00:00\&nia=4215235> Acesso em 20 mar. 2013.

268 Arion Sayão Romita, Conflito de normas em direito do trabalho, p. 74.
} 
empresas", e, com amparo em Rivero e Savatier, o autor exemplifica o que poderá ocorrer com o contrato de trabalho inicial:

a) simples envio em missão, deixando de subsistir o contrato inicial; b) o empregador tendo apenas delegado sua autoridade ao dirigente da empresa utilizadora dos serviços; c) novação do contrato pela troca do empregador, de comum acordo com o empregado; d) convenção implicando suspensão do contrato inicial, que tem vocação de retomar seus efeitos em caso de cessão do destacamento. ${ }^{269}$

Um marco importante para uma inclinação à preferência para a lei mais benéfica foi o cancelamento da Súmula n. 207, aprovado pelo Pleno do TST em 16.04.2012. A Súmula tratava do conflito de leis trabalhistas no espaço, mediante a aplicação do princípio da lex loci executionis, que definia como lei de vigência para a relação jurídica as leis do país da prestação de serviço, e não aquelas do local da contratação.

No entender de Amauri Mascaro Nascimento, o princípio da lex loci executionis foi gradualmente substituído pela aplicação da norma mais favorável ao trabalhador, em consequência das discussões práticas e teóricas que eram travadas no meio trabalhista há alguns anos. Um ponto importante foi a ampliação do âmbito de aplicação Lei n. 7.064/1982, que regula a situação de trabalhadores contratados ou transferidos para prestar serviço fora do País, trazida pela Lei n. 11.962/2009.

Desde então, os trabalhadores abrangidos no art. $1 .^{\circ}$ passaram a ter o direito da aplicação da legislação brasileira de proteção ao trabalho, quando mais favorável que a legislação do país de destino. Portanto, o cancelamento da Súmula, na avaliação de Nascimento, foi correto e necessário. ${ }^{270}$

Entretanto, o cancelamento da Súmula em nada altera entendimento já reconhecido pela doutrina, de que o princípio da territorialidade não está afastado, porém, tampouco atua de forma absoluta. É dizer, não se aplica indistintamente a todos os casos.

269 Antonio Galvão Peres, Contrato internacional de trabalho: acesso à justiça conflitos de jurisdição e outras questões processuais, p. 147.

270 Disponível em: <http://www.amaurimascaronascimento.com.br/index.php?option=com.content8_ sumula-207-cancelada=255>. Acesso em: 29 mar. 2013. 
A esse respeito, Maranhão concluiu que "este princípio geral da aplicação da lei do local da prestação dos serviços supõe que o trabalho se realize de modo permanente em determinado país". Nessa hipótese, entende o autor que não há dúvidas sobre a preponderância da legislação nacional. "Do contrário, se o trabalho é efetuado em caráter transitório em um lugar, por exemplo, nos Estados Unidos, mas continua a ser outro o local da ocupação principal, por exemplo, o Brasil”, entende o autor que será aplicável a lei do país em que o contrato normalmente se executa. ${ }^{271}$

Na mesma linha, Süssekind defende, em síntese, que na transferência de caráter transitório, assim entendida aquela em que o empregado permanece juridicamente vinculado ao estabelecimento que o enviou para prestar serviços em outro país, serão garantidos os direitos trabalhistas mínimos, de ordem pública previstas no país de origem, a exemplo do FGTS, férias e $13 .^{\circ}$ salário. $^{272}$

Em resumo, a melhor doutrina trabalhista ensina que a manutenção de direitos trabalhistas previstos na legislação do país de origem se aplica às situações de transitoriedade da transferência e continuidade da vinculação à empresa da origem, durante a expatriação.

Excepcionalmente, poder-se-á aplicar a legislação mais benéfica, se houver indícios de fraude na rescisão operada com a unidade brasileira, acarretando a nulidade da rescisão e decretação da continuidade do vínculo empregatício com a entidade local,

\subsubsection{Grupo econômico e unicidade contratual}

Nas relações jurídicas desenvolvidas no território brasileiro, o conceito de grupo econômico poderá repercutir profundamente na relação jurídica que se estabelece durante a migração, quando o migrante mantém ativo, simultaneamente, o contrato de trabalho no país de origem e no Brasil, e aqui prestará serviços para outra empresa, que possui laços societários com empresa sediada no exterior.

271 Délio Maranhão, Instituições de direito do trabalho, p. 177.

2 Arnaldo Sussekind, Conflitos de leis do trabalho, p. 43-47. 
A depender do liame de ligação entre as duas empresas, configurar-se-á o grupo econômico, conceito que na esfera trabalhista se extrai do art. $2 .^{\circ}, \S 2 .^{\circ}$, da CLT.

Pelo critério estabelecido neste dispositivo legal, existirá um grupo econômico quando uma ou mais empresas, embora tendo cada uma delas personalidade jurídica própria, estiverem sob a direção, controle ou administração de outra. O grupo econômico também pressupõe a existência de uma empresa principal ou controladora e uma ou várias empresas controladas.

Neste sentido, Cássio Mesquita Barros considera que, quando há conexão entre as empresas nesse formato de subordinação e controle, não há como se defender que a transferência de empregados de uma para outra empresa coligada possa resultar que apenas uma suporte os encargos de remunerar o pessoal e a outra com os benefícios dos serviços, daí a ideia preponderante na doutrina de que ocorrerá a responsabilização solidária de todas as empresas do grupo pelos direitos que devem ser assegurados ao trabalhador, independentemente da lei de regência do contrato. ${ }^{273}$

Um passo adiante nessa seara de conflitos requer a análise do conceito de unicidade contratual, conceito este diretamente ligado à ideia da configuração do grupo econômico. Sim, porque, estando configurado o grupo econômico pela existência da relação e subordinação e coordenação entre as empresas, poderá se configurar uma única relação jurídica entre o trabalhador e as empresas jungidas pelo grupo econômico. Sob essa conformação, a jurisprudência se inclina no sentido de que a prestação de serviços para mais de uma empresa do mesmo grupo econômico configura-se como única. Nesse sentido, a posição do Tribunal Superior do Trabalho, na Súmula n. 129:

Súmula 129. Contrato de Trabalho - Grupo Econômico. A prestação de serviços a mais de uma empresa do mesmo grupo econômico, durante a mesma jornada de trabalho, não caracteriza a coexistência de mais de um contrato de trabalho, salvo em ajuste contrário.

O conceito de grupo econômico implica reconhecer que, em determinadas circunstâncias, as empresas poderão atuar como um único empregador. Entretanto, é importante observar que essa regra não é absoluta. Poderá, isso sim, tal regra importar

${ }^{273}$ Cassio Mesquita Barros, Transferência de empregados urbanos e rurais, p. 90-95. 
responsabilidade solidária das empresas jungidas por um grupo econômico, pelo pagamento dos direitos trabalhistas do empregado migrante, mas, daí até se concluir que haverá a caracterização de um contrato único, há um universo de evidências fáticas que requerem análise caso a caso.

Há que se perquirir, a fim de que se respeite a segurança jurídica para ambas as partes, se há um elemento de conexão entre a relação que se iniciou em determinado país e que se desenvolveu em outro.

Essa não é uma tarefa fácil, pois exige investigar a intenção das partes no momento em que avençaram a mobilidade internacional de uma relação jurídica iniciada no país de origem.

Temos para nós que, se persistir um traço de subordinação entre o trabalhador e a empresa do país de origem, poder-se-ão se constituir elementos de conexão que revelariam indícios de unicidade contratual. Em outras palavras, esse elemento poderia atuar para definir uma relação jurídica internacional e constituir fortes indícios de uma relação de emprego única, continuada durante o período de migração para o exterior.

Somando-se esses indícios à configuração de um grupo econômico entre a empresa do país de origem e de destino, poder-se-ia, em tese, caminhar para a responsabilidade solidária das empresas pelos direitos trabalhistas assegurados ao trabalhador e, ainda, uma intensa discussão sobre a legislação trabalhista aplicável ao contrato, se a local ou à do país de destino, ou, ainda, sobre a possibilidade de aplicação da que fosse mais favorável ao trabalhador.

Do contrário, ou seja, a existirem elementos que indiquem ter havido, em determinado momento da relação jurídica local, a decisão das partes sobre a migração permanente do trabalhador para outro país, mediante ato inequívoco de desvinculação do trabalhador do contrato de trabalho local, a nosso ver, essa circunstância favoreceria a conclusão da prevalência da legislação trabalhista do país de destino sobre o contrato de trabalho, em detrimento da continuidade da incidência da legislação do país de origem. 
Essa questão, todavia, é ainda fruto de enorme insegurança jurídica para as partes e não raro atrai decisões conflitantes por parte do Poder Judiciário do país de origem e de destino.

As implicações do conceito da unicidade contratual e consequentemente a discussão sobre a extensão da aplicação da legislação de ambos os países sobre a relação de trabalho respingam diretamente nos princípios informativos dos contratos de trabalho internacional, à medida que levam a concluir que um contrato iniciado no exterior poderá ter continuidade no exterior.

Sob o cenário legislativo e jurisprudencial brasileiro, a persistir um elemento de conexão entre um contrato que se iniciou em outro país e, em dado momento, se deslocou via migração internacional para o Brasil, poderemos nos defrontar com uma relação continuada (única), acompanhada da responsabilidade solidária das empresas contratantes (no país de origem e no país de destino) e, com isso, desaguar, inclusive para restrição a quaisquer modificações nas condições pactuadas ao longo do desenvolvimento dessa relação jurídica.

Logo, qualquer modificação em uma relação tida como única e continuada terá sua validade submetida à análise sob a regra do art. 468 da CLT, segundo o qual só é válida a alteração contratual bilateral e, ainda assim, desde que não resulte em prejuízos diretos ou indiretos ao empregado.

Decorre daí que o fracionamento ou a suspensão do contrato de trabalho iniciado no país de origem é matéria extremamente controvertida.

Em que pese a afirmação de Peres ${ }^{274}$ sobre a permissibilidade, em tese, do fracionamento do contrato de trabalho internacional, inclusive para fins de determinação da lei de vigência, o fazendo com amparo no art. 3.1 da Convenção de Roma de 1980 e no art. 7. ${ }^{\circ}$ da Convenção do México, de 1994 e, ainda, na doutrina de Jean-Michel Jacquet, não vislumbramos terreno seguro a viabilizar tal prática à luz do ordenamento jurídicotrabalhista brasileiro.

274 Antonio Galvão Peres, Contrato internacional de trabalho: acesso à justiça conflitos de jurisdição e outras questões processuais, p. 140-141. 
O principal empecilho à efetivação de tais arranjos, ainda que pretendidos por mútuo acordo entre empregador e empregado, reside na preponderância do princípio do contrato realidade, no ordenamento jurídico-trabalhista brasileiro, como um vetor de proteção ao empregado. A nosso ver, mais direcionado ao migrante de pouca escolaridade do que ao alto executivo que o sujeito mais comumente encontrado em situações envolvendo a mobilidade entre empresas multinacionais.

O contrato realidade é, como esclarece Fernando Hoffmann, um termo cunhado pelo Ministro da Suprema Corte de Justiça do México e posteriormente difundido por Mário De La Cueva, que equivale à ideia de que as regras aplicáveis à relação de emprego não existem em função do contrato, mas decorrem do regramento que se consolidar durante a prestação dos serviços. Corolário do contrato realidade, prevalece no Brasil o princípio da primazia da realidade. ${ }^{275}$

Na prática, isso não implica, por si só, a declaração da unicidade contratual, para a soma de direitos trabalhistas que foram assegurados ao empregado em um e outro contrato.

A nosso ver, em transferências de caráter permanente, a unicidade contratual só deveria impor-se em caso de arranjos fraudulentos.

Exemplo: quando o trabalhador tem seu contrato rescindido e posteriormente é admitido por outra empresa pertencente ao mesmo grupo, sem que ocorra nenhuma alteração de fato em suas atribuições e permanece intacta a sua vinculação à unidade de origem, sobretudo se remanescer a subordinação hierárquica anterior.

A fraude também poderá se configurar pela obrigação de restituir a multa sobre os depósitos do FGTS, denotando que a ruptura do vínculo no Brasil não foi real, e sim fantasiosa, para evitar a aplicação conjunta de regras trabalhistas do país de origem e do país de destino.

275 Fernando Hoffmann, disponível em: 〈http://www.trt9.jus.brlapejlartigos_doutrina_fh_01.asp〉. Acesso em: 1. ${ }^{\circ}$ out. 2013. 
Corrobora esse posicionamento o art. 453 da CLT, que exclui o direito do empregado à soma do período anteriormente trabalhado na mesma empresa, se tiver recebido indenização legal. Assim, a boa-fé deveria atuar como um divisor de águas na aplicação do princípio da realidade contratual.

Há, inclusive, posicionamento da jurisprudência nesse sentido e sinais de contemporaneidade foram verificados nas decisões mais recentes do Tribunal Superior do Trabalho, a exemplo do recente acórdão proferido em situação análoga, cujo trecho mais relevante segue reproduzido:

O fato de as empresas pertencerem ao mesmo grupo econômico, bem como o fato de o autor ter exercido as mesmas funções em pelo menos duas das três empresas, não se traduz, automaticamente, na alegada simulação e no reconhecimento da unicidade contratual pretendida. Nos termos do $\S 2 .^{\circ}$ do art. $2 .^{\circ}$ da CLT, o efeito jurídico da existência de um grupo econômico é a responsabilização solidária das empresas que o integram em relação aos créditos trabalhistas devidos pelo empregador ao empregado. Logo, o fato de um trabalhador ter o seu contrato rescindido e posteriormente ser admitido por outra empresa pertencente ao mesmo grupo não gera a unicidade contratual. A resilição contratual ocorrida em $1 .^{\circ} .04 .2002$, conforme o TRCT da fl. 116, observou todas as determinações legais, sem qualquer prejuízo ao obreiro. Além disso, a formalização da resilição contratual foi realizada com a assistência do Sindicato dos Trabalhadores Metalúrgicos na Fund. e na Sid. e na Ind. do Mat. Elétrico de Joinville, "homologado" o TRCT sem ressalva quanto ao fato, tão somente com relação a diferenças relativas à database, diferenças essas que não fizeram parte do rol de pedidos da presente ação. Inclusive, como bem lembrado no decisum ora revisando, o empregado sacou os depósitos de FGTS logo após a formalização da ruptura contratual e, também, recebeu seus haveres trabalhistas. Portanto, não verifico a existência de elementos que levem à conclusão de que a nova contratação teve o intuito de fraudar a aplicação da legislação trabalhista. Já tive oportunidade de julgar processo com fatos e pedidos semelhantes, envolvendo a ré Tupy Fundições Ltda., ao qual, por unanimidade, foi negado provimento, pelos mesmos fundamentos ora expendidos (Proc. n. 02213-2005-028-12-00-9, RO-V 16636/2006). Ainda, corroborando meu posicionamento, trago à colação julgados deste Regional: [...] Tenho, então, por regular a resilição contratual ocorrida em 01/04/2002. Assim, declaro prescrito o direito de ação em relação ao primeiro contrato, vigente de 08.11 .2000 a $1^{\circ} .04 .2002$ e mantido com a primeira demandada (Tupy Fundições Ltda.), por decorrido o biênio previsto no art. $7 .^{\circ}, \mathrm{XXIX}$, da $\mathrm{CF} / 88$, quando da interposição da presente ação (em 15.08.2006). Em face da incontrovérsia no tocante à existência de grupo econômico, não há falar em ilegitimidade da primeira requerida (Tupy Fundições Ltda.), que deve ser mantida no polo passivo. Como corolário do reconhecimento da regularidade da resilição contratual, dou provimento também para afastar a obrigação de retificação da CPTS, bem como para revogar a determinação de expedição de ofícios ao Ministério Público, ao 
Ministério Público do Trabalho e à União (fls. 295-verso/299. Negritouse.) Às fls. 331/334, afirma o reclamante que as provas produzidas demonstram que a $1 .^{a}$ reclamada é controladora da $2{ }^{a}$ reclamada e da American Iron Alloys Corporation - AIA. Diz que prestou serviços para a $1 .^{\text {a }}$ reclamada e, sem qualquer interrupção, foi remanejado para as subsidiárias dos EUA. Diz que dessa situação já é possível se presumir a fraude. Aduz ter havido de forma inquestionável sucessão de empregadores, nos termos dos artigos 10 e 448 da CLT. Aponta violação dos artigos $9^{\circ}, 100^{\circ}$ e 448 da CLT, além de trazer os arestos de fls. 333/334 como divergência jurisprudencial.

Sem razão. Conforme afirmado pelo acórdão regional, o fato do reclamante ter rescindido seu contrato de trabalho e posteriormente ter sido contratado por outra empresa do grupo econômico não induz à conclusão de que tal procedimento foi maculado por fraude. Tanto é assim que o acórdão regional consigna que a rescisão contratual observou todas as determinações legais, sem prejuízo ao recorrente, que o procedimento foi realizado com a assistência sindical, com ressalva apenas em relação às diferenças relativas à data-base e que o reclamante, inclusive, sacou os depósitos de FGTS logo após formalizada a ruptura contratual (TST, Recurso de Revista n. TST-RR-36330080.2006.5.12.0004, em que é recorrente Geraldo Leonel Estevam da Silveira e são Recorridas Tupy Fundições Ltda. e outra. Acórdão publicado em 01.04.2011, Rel. Min. Dora Maria da Costa). ${ }^{276}$

\subsubsection{Alterações contratuais}

Em consequência da unicidade contratual, poderá haver um limitador para alterações contratuais, segundo a mens legis do art. 468 da CLT, que consiste em presumir viciado o consentimento do empregado com condições que se revelem prejudicais ao seu interesse pessoal.

A regra parte do desequilíbrio entre o empregador e o empregado, quando este assina um contrato de trabalho e fica sob tal estado de subordinação que se entende afetada a sua liberdade de decidir e, bem assim, de manifestar livremente a sua vontade. Concordará, no mais das vezes, com a alteração que interessa apenas ao empregador, dado o temor do desemprego.

Filiamo-nos ao pensamento de Mascaro, no sentido de que o contrato de trabalho, como expressão da autonomia da vontade dos contratantes, pode melhor atender

276 Disponível em: <https://aplicacao5.tst.jus.br/consultaProcessual/consultaTstNumUnica.do? consulta= Consultar \&conscsjt $=\&$ numeroTst $=363300 \&$ digitoTst $=80 \&$ anoTst $=2006 \&$ orgaoT $\mathrm{Tt}=5 \&$ tribunalTst $=12 \&$ varaTst=0004>. Acesso em: 3 abr. 2013. 
aos imperativos da contratação, indicados os direitos do trabalhador, independentemente do país em que estiver transitoriamente prestando serviços. ${ }^{277}$

Daí importância de identificar, em documento apropriado, assinado pelo empregado, as verbas que vigorarão durante a transferência, justificando-se a respectiva finalidade - que deverá estar atrelada às necessidades de trabalho durante a transferência em valores razoáveis em relação ao custo de vida do país de destino, de modo que se tornem hábeis a justificar sua supressão ao término da expatriação, sem confundi-las com direitos adquiridos ao longo da carreira.

Em que pese a defesa da autonomia das partes, é fato que a aplicação práticas conjunta das regras jurídico-trabalhistas sobre o grupo econômico, a unicidade contratual e a presunção de vício de consentimento para alterações contratuais na relação jurídica que se estabelece de forma triangular, entre o migrante, a empresa de origem e a empresa de destino, dão margem a inúmeras situações que colocam em risco a segurança jurídica das partes, pois não tratam com clareza como se aplicarão os direitos trabalhistas do trabalhador migrante.

\subsection{Lei n. 7.064/1982}

No mesmo cenário em que repercutem os conceitos de grupo econômico, unicidade contratual e vedação a alterações contratuais lesivas, também atuará a Lei n. $7.064 / 1982$.

No que concerne aos trabalhadores locais e à situação de emigração que se desencadeia a partir do Brasil, há que se mencionar a Lei n. 7.064/1982, que estabelece, em linhas gerais, a aplicação da lei mais benéfica ao trabalhador transferido do Brasil para o exterior nas hipóteses que especifica.

Essa legislação, embora com foco bem definido, em seu Capítulo II, aos trabalhadores contratados no Brasil ou transferidos para o exterior e que mantenham vínculo com empresa no Brasil, ou, conforme o Capítulo III, venham a ser contratados no

277 Amauri Mascaro Nascimento, Teoria geral do direito do trabalho, p. 211. 
Brasil, com a finalidade de prestarem serviços a empresa estrangeira localizada no exterior, da qual uma empresa brasileira participe com pelo menos 5\% do capital, tem se revelado um importante instrumento na garantia da defesa dos direitos dos trabalhadores nacionais.

Essa iniciativa também faz parte de outras legislações de proteção ao trabalhador local, durante período de migração para o exterior, a exemplo de Portugal, que também prevê a proteção do nacional contratado em Portugal para prestar serviço no estrangeiro. Garriges ressalta que:

O destacamento de trabalhadores para outros Estados é tratado no art. 9. ${ }^{\circ}$ do Código de Trabalho de Portugal e, de acordo com essa disposição, o trabalhador que se encontre vinculado a uma empresa portuguesa estabelecida em território nacional e que execute a sua prestação de trabalho noutro território, em execução de contrato celebrado entre empregador e beneficiário ainda que em regime de trabalho temporário, tem direito às condições de trabalho previstas para o deslocamento em território português (art. 8. ${ }^{\circ}$ do Código de Trabalho n. 1-31), sem prejuízo dos regimes mais favoráveis constantes na lei aplicável à relação laboral ou previstos contratualmente. ${ }^{278}$

Em 2009, por meio da Lei n. 11.962/2009, houve a ampliação dessa legislação para contemplar trabalhadores de todos os segmentos econômicos.

Essa alteração reflete o saldo positivo que a relação entre os emigrantes e o governo brasileiro tem apresentado nos últimos dez anos. Durante uma reunião inédita, realizada em 2008, o governo convidou uma centena de brasileiros espalhados pelo mundo, em sua grande maioria sem vínculos trabalhistas com empresas brasileiras, logo, por sua conta e risco, em território estrangeiro, para se reunir no Palácio do Itamaraty, no Rio de Janeiro, em que foram discutidos assuntos de interesse dos emigrados que, posteriormente, resultou no Guia Brasileiros e Brasileiras no Exterior, com dicas práticas sobre leis de migração, direitos trabalhistas, previdenciários, regresso ao Brasil, entre outros. ${ }^{279}$

Reis ressalta a existência de um fator econômico nessa aproximação, identificado pela relevância das remessas financeiras enviadas pelos brasileiros aos

\footnotetext{
278 Garriges Portugal, Jusprático laboral e segurança social, p. 83.

279 Disponível em: <http://portal.mte.govlcartilha_exteriorlsumario.htm>. Acesso em: 5 out. 2013.
} 
parentes que ficaram no país, que, somado à condição de votantes, contribuíram para uma tomada de consciência por parte do Estado brasileiro. ${ }^{280}$

A inovação trazida pela Lei n. 11.962, de 06.07.2009, que alterou o art. $1 .^{\circ}$ da Lei n. 7.064, de 06.12.1984, foi essencialmente extensão da aplicação da lei (antes restrita aos trabalhadores contratados por empresas prestadoras de serviços de engenharia, consultoria, projetos e obras, montagens, gerenciamento e congêneres) para todos os empregados de quaisquer segmentos econômicos, que venham a contratar ou transferir trabalhadores locais para prestar serviços no exterior.

Nessa medida, a Lei n. 7.064, de 1982, agora estendida a todas as empresas, fixa uma exceção, ainda que parcial, ao princípio da territorialidade, assegurando aos trabalhadores expatriados, a partir de empresas domiciliadas no Brasil, a aplicação de normas de proteção previstas na legislação brasileira; intensifica as discussões em torno dos conflitos de leis trabalhistas no espaço, quando empresas envolvidas de outros segmentos econômicos enfrentam as mesmas questões abordadas no item anterior sobre a aplicação do princípio da territorialidade e lei mais benéfica.

Antes da vigência da Lei n. 11.962, as empresas de outros segmentos contratavam trabalhadores ou transferiam os atuais para o exterior, considerando apenas a aplicação da lei do país em que o trabalhador prestava serviços. Portanto, o FGTS e o INSS não eram recolhidos sobre as verbas de natureza salarial pagas ao expatriado no exterior.

Eram, aliás, muito comuns a suspensão, a interrupção ou a rescisão do contrato de trabalho local antes do deslocamento do trabalhador para o exterior, objetivando as partes evitar a incidência da lei do local da contratação, aplicando-se, em substituição, apenas a lei do local da prestação de serviços durante o período de migração.

Com a promulgação da Lei n. 11.962/2009, a lei em questão passou a disciplinar todos os casos em que, doravante, o trabalhador for contratado no Brasil, ou transferido por seu empregador, para trabalhar no exterior, garantindo aos trabalhadores

280 Rossana Rocha Reis, A política do Brasil para as migrações internacionais. Disponível em: <http://www.Scielo.brlscielo.php:script+sci_arttex\&pid=S102-

8529202011000100002\&ing=en\&nrm=iso>. Acesso em: 5 out. 2013. 
direitos trabalhistas durante o período de expatriação, na seguinte medida: a) naquilo que não for incompatível com suas disposições; b) quando mais favorável que a legislação nacional, analisada no conjunto de normas em relação a cada matéria; c) excepcionalmente, aplicar-se-á a legislação do país da prestação dos serviços, apenas para os profissionais contratados por empresa estrangeira para trabalhar no exterior.

A principal dificuldade de contornar em relação à renovada Lei n. 7.064/1982 reside no fato de que, ao estender seus preceitos aos demais segmentos econômicos, o legislador não cuidou de rever todos os aspectos de uma lei que já está há muito ultrapassada.

\subsubsection{Disposições específicas da Lei n. 7.064/1982}

A lei apresenta disposições específicas e distintas quanto às seguintes situações: a) transferidos (seja mediante ajuste de transferência, remoção ou cessão) e contratados por empresa sediada no Brasil para trabalhar a seu serviço no exterior. A estes se aplica o Capítulo II; b) contratação de empregado por empresa estrangeira, para trabalhar no exterior, aos quais se aplica Capítulo III.

\subsubsection{Trabalhadores abrangidos no Capítulo II}

Empregados transferidos e contratados por empresa sediada no Brasil para trabalhar a seu serviço no exterior são tratados no Capítulo II, que regula as hipóteses da letra "a" - transferidos (de forma geral) e contratados por empresa sediada no Brasil para trabalhar a seu serviço no exterior. A esse contingente de trabalhadores, se aplicarão os direitos trabalhistas previstos na lei brasileira durante o período de transferência para o exterior. Apenas excepcionalmente será admitida a prevalência da legislação do país de destino, desde que se comprovar ser esta mais favorável do que a legislação territorial, no conjunto de normas e em relação a cada matéria.

De acordo com a disposição do art. 1. ${ }^{\circ}$ da Lei n. 7.064/1982, o Capítulo II se aplica a toda pessoa contratada no Brasil ou transferida para prestar serviços no exterior, exceto ao empregado designado para prestar serviços de natureza transitória, por período não superior a 90 dias, desde que tenha ciência expressa dessa transitoriedade e que 
receber, além da passagem de ida e volta, diárias durante o período trabalhado no exterior, as quais, seja qual for o respectivo valor, não terão natureza salarial.

A questão envolvendo os projetos de curta duração sob a aludida lei nem sempre funciona bem na prática. Basta mencionar a hipótese em que o trabalhador é destacado para um projeto de curta duração que extrapola os tais 90 dias, sem, contudo, implicar mudança de residência do trabalhador para o exterior, que por essa razão continuará hospedado provisoriamente no local de destino, com suas despesas custeadas integralmente pelo empregador, continuará vinculado à empresa no Brasil, de quem receberá os salários e demais verbas pactuadas no Brasil.

A Lei n. 7.064/1982 merece reforma nesse ponto, posto que não se sustenta à luz de interpretação teleológica e sistemática, segundo a qual há que se buscar qual é o fim almejado pela norma, levando-se em conta os institutos jurídicos correlatos. Objetivamente, a finalidade da Lei n. 7.064/1982 é estender direitos trabalhistas do ordenamento jurídico brasileiro aos trabalhadores "transferidos" para prestar serviços no exterior.

O conceito de transferência no ordenamento jurídico brasileiro traduz a ideia de alteração de residência do empregado (art. 469, caput, da CLT). A Lei n. 7.064/1982 adotou a mesma linha da CLT, o que se denota da redação do art. 2. ${ }^{\circ}$ do Capítulo II, que conceitua o empregado transferido como aquele que é contratado, removido ou cedido para prestar serviços no exterior. Essa ideia de mudança, para fins de aplicação da Lei n. 7.064/1982, é confirmada no art. 1. ${ }^{\circ}$, que tratou de excluir do regime da lei as designações eventuais, ou seja, aquelas em que não há o animus de alteração de residência.

A lei, todavia, menciona um período máximo de até 90 dias para que a designação internacional seja considerada transitória e excluída do regime da lei. A interpretação isolada desse dispositivo poderia conduzir à conclusão de que a lei incidiria sobre todas as designações por períodos maiores, o que não nos parece ter sido o objetivo do legislador. 
O conceito de transferência em nosso ordenamento jurídico está atrelado à mudança de residência do trabalhador. Se isso não ocorre, a jurisprudência pacífica (Orientação Jurisprudencial n. 113/SBDI-1-Tribunal Superior do Trabalho) é no sentido de que não incidem os direitos correlatos, a exemplo do adicional de transferência.

Ademais, no caso concreto, as peculiaridades da designação internacional a que sujeitam os trabalhadores migrantes de projetos de curta duração envolvem no mínimo o reembolso de todas as despesas, e o retorno mensal ao Brasil indica que esse contingente de trabalhadores não é o foco de proteção da Lei n. 7.064/1982, pela simples razão de que a designação não se assemelha a uma transferência.

Em que pese permanecerem por período superior a 90 dias no exterior, ainda assim não se enquadram no conceito de transferência preconizado por nosso ordenamento jurídico (art. 469 da CLT), uma vez que sua estadia é normalmente realizada sem os familiares e é entrecortada por retornos mensais ao Brasil, assemelhando-se a uma viagem a trabalho mais prolongada, na qual todas as despesas serão custeadas pela empregadora a partir do Brasil.

$\mathrm{Na}$ dicção do art. 2. $^{\circ}$, considera-se transferido o empregado removido, cujo contrato estava sendo executado no Brasil, cedido, desde que mantido o vínculo trabalhista com o empregador brasileiro e o contratado no Brasil para trabalhar a serviço da contratante no exterior.

As disposições do art. $2 .^{\circ}$ revelam claramente o objetivo do legislador em abarcar a maior variedade possível de arranjos realizados para formalizar a mobilidade internacional dos trabalhadores a partir do Brasil.

Nessa linha, remoção é a palavra que designa o ato pelo qual se afasta o indivíduo do lugar ou posição em que se encontra para outro lugar ou posição. A cessão indica o ato pelo qual se cedem ou se transferem a outrem direitos ou bens que lhe pertencem. A palavra foi utilizada para expressar que a lei se aplica quando o empregado é cedido/transferido à empresa sediada no estrangeiro, mas mantém o vínculo trabalhista com o empregador brasileiro, e, finalmente, a lei se aplica também ao indivíduo contratado no Brasil para trabalhar no exterior a serviço da contratante. 
Em linhas gerais, os seguintes os contratos em curso e aos novos contratos dos empregados transferidos internacionalmente por períodos superiores a 90 dias, exigirão ajustes na seguinte medida:

a. Ajustar, por escrito, com o empregado, o valor do salário-base que vigorará durante a transferência: a.1. o valor não poderá ser inferior ao piso da categoria profissional; a.2. Esse salário-base deverá ser estipulado em Reais; a.3. Sobre o salário-base e outras parcelas salariais que remanescerem estipuladas em Reais, a empresa deverá incidir os reajustes e aumentos compulsórios previstos na legislação brasileira (Convenção Coletiva);

b. Ajustar, por escrito, com o empregado, o valor do adicional de transferência: a.1. A lei não especifica o valor do adicional de transferência e, a nosso ver, não se deveria aplicar por analogia o percentual de $25 \%$ previsto no art. $469, \S 3 .^{\circ}$, da CLT, posto que há disposição expressa sobre o tema no art. $4 .^{\circ}$ da Lei n. 7.064/1982, que confere às partes a fixação dos valores do salário-base e do adicional de transferência. Evidentemente, deverá o adicional ser estipulado em valor razoável e compatível com as necessidades de trabalho enfrentadas no país de destino;

c. Em suma, no caso da transferência internacional, o adicional poderá ser estipulado em percentual que confira ao transferido um suplemento de renda que retribua o desgaste pessoal e familiar; a.2. O adicional de transferência possui caráter salarial. Conquanto possa ser suprimido ao retorno do transferido ao país de origem, enquanto pago deverá servir de base de cálculo para o cômputo dos depósitos do FGTS e outras parcelas contratuais;

d. Ajustar, por escrito, com o empregado, o valor da remuneração (ou seja, qual será o valor total devido ao empregado mensalmente durante a transferência); 
e. Facultar ao empregado exercer a opção pelo depósito da remuneração fixada em Reais em conta bancária no exterior, mediante conversão para a moeda do país de destino;

f. Férias: após dois anos de transferência, a empresa (unidade do Brasil ou do Exterior) deve facultar a ele usufruir de férias no Brasil, com o custeio da passagem dele e dos familiares e dependentes;

g. Seguro de vida e acidentes pessoais: a empresa deverá assegurar tal seguro em favor do trabalhador a partir do embarque para o exterior até o retorno para o Brasil; o valor do seguro não poderá ser inferior a 12 vezes o valor da remuneração mensal do trabalhador;

h. Retorno: no fim da transferência, a empresa deverá custear o retorno do empregado, dos familiares e dependentes, exceto se ocorrer a rescisão do contrato por iniciativa do empregado ou se houver rescisão por justa causa;

i. A empresa deverá manter o recolhimento das contribuições para a Previdência Social brasileira, FGTS e PIS;

j. Quanto ao Imposto de Renda, observar o Regulamento do Imposto de Renda - Decreto n. 3.000/1999, além de acordos internacionais para evitar a dupla tributação.

\section{- Salário-base}

No que diz respeito ao salário-base, as disposições dos arts. $4 .^{\circ}$ e $5 .^{\circ}$, caput, regulamentaram o que já era prática nas empresas: o ajuste de um salário-base durante a transferência, que o empregador assegurava notadamente para prevenir a perda da condição de segurado no regime da previdência social do Brasil.

O legislador manteve a possibilidade de as partes ajustarem um salário-base, estipulado em moeda nacional, não inferior ao mínimo estabelecido para a categoria profissional, sujeito a reajustes e aumentos compulsórios previstos na lei brasileira. 
A lei admite que o valor possa ser inferior à remuneração recebida pelo expatriado antes da transferência internacional, o que evidentemente não significa que poderá o empregador promover redução prejudicial ao empregado. Tampouco houve intenção do legislador em validar o procedimento de incidência de FGTS e INSS sobre essa base salarial reduzida.

A estipulação do salário-base leva em conta que haverá uma remuneração global devida durante a transferência a ser paga em moeda nacional ou estrangeira, que servirá de base de cálculo para todos os efeitos trabalhistas.

\section{- Remuneração}

A remuneração global ajustada entre as partes para vigorar durante a transferência, na qual se computa o adicional de transferência, poderá, no todo ou em parte, ser paga no exterior, em moeda estrangeira. O empregado tem direito a optar, por escrito, por receber a remuneração paga em moeda nacional mediante depósito em sua conta bancária (art. 5. ${ }^{\circ}, \S 1 .^{\circ}$ ). É também assegurado ao empregado o direito de ter a conversão do valor em moeda nacional e a remessa para o país de destino (art. $5 .^{\circ}, \S 2 .^{\circ}$ ).

\section{- Adicional de transferência}

Quanto ao adicional de transferência, é importante observar que a Lei n. 7.064/1982 estabelece uma distinção entre os migrantes cuja transferência internacional ocorre a partir do Brasil para o exterior, em detrimento dos migrantes transferidos do exterior para o Brasil.

$\mathrm{O}$ adicional de transferência previsto no art. 10 só é garantido ao primeiro grupo (migrantes cuja transferência ocorre a partir do Brasil), e só este grupo terá seu valor fixado pelo empregado e empregador e computado na remuneração devida. Dispõe também o art. 10 da Lei que o adicional não será devido no retorno do expatriado ao Brasil, assim como serão suprimidas as prestações in natura, bem como quaisquer outras vantagens a que fizer jus o empregado em função de sua permanência no exterior. 
Nota-se que, em certa medida, a disposição do art. 10 da Lei n. 7.064/1982 resulta em flexibilização do disposto no art. 468 da CLT, permitindo, ao retorno do expatriado, a supressão do adicional de transferência, prestações in natura e quaisquer outras vantagens.

Do exposto, a única lacuna da lei relativa ao adicional de transferência reside na ausência de fixação do percentual devido, pois a lei limita-se a dizer que aludido adicional é computado na remuneração e que poderá ser pago em moeda nacional ou estrangeira. Nada dispõe sobre o valor, que assim fica sob a livre fixação entre as partes (art. 4. ${ }^{\circ}$, caput).

Daí por que disseminou-se entendimento voltado à aplicação, por analogia do art. 469 da CLT, que fixa o adicional em no mínimo 25\%. Essa possibilidade vem sendo negada na doutrina ao argumento de que o dispositivo em tela objetiva apenas regular situação da transferência nacional.

De fato, a lei especial passou a regular a matéria no que diz respeito ao percentual, que poderá ser livremente pactuado entre as partes. Contudo, no que tange ao direito do expatriado de integração do adicional de transferência na remuneração, enquanto durar a transferência, entendemos que ainda há espaço para aplicação, por analogia, da natureza jurídica que possui o adicional de transferência no âmbito nacional e que inegavelmente conduz para a natureza salarial enquanto durar a transferência.

\section{- Outros direitos legais e contratuais previstos no Capítulo II}

Matéria de difícil análise consiste nas vantagens concedidas ao expatriado com duração predeterminada para o período da transferência internacional. Não é fácil distinguir, dentre os diversos títulos, quais foram outorgadas ao expatriado por conta da permanência e quais resultam da própria evolução da carreira do profissional, notadamente em uma empresa global. Estas últimas, à luz da Convenção da OIT n. 97, combinada com o art. 468 da CLT, não poderiam ser suprimidas ao término da transferência porque implicariam afronta aos direitos adquiridos. 
Daí a importância de identificar, em documento apropriado, assinado pelo empregado, as verbas que vigorarão durante a transferência, justificando-se a respectiva finalidade - que deverá estar atrelada às necessidades de trabalho durante a transferência em valores razoáveis em relação ao custo de vida do país de destino, de modo que se tornem hábeis a justificar sua supressão ao término da expatriação, sem confundi-las com direitos adquiridos ao longo da carreira.

\subsubsection{Trabalhadores abrangidos no Capítulo III}

O capítulo III, art. 12, da Lei n. 7.064/1982, trata da contratação de trabalhador por empresa estrangeira para trabalhar no exterior.

$\mathrm{Na}$ hipótese de empregado contratado por empresa estrangeira, para prestar serviço no exterior, entende-se aplicável a lei do país da prestação dos serviços, exatamente na linha do disposto no art. 198 do Código de Bustamante e posição jurisprudencial da Súmula n. 207 do TST.

Assim, verifica-se pela redação do art. 14, do mesmo diploma legal, que apresenta a seguinte disposição:

"Sem prejuízo da aplicação das leis do país da prestação dos serviços no que respeita a direitos, vantagens e garantias trabalhistas e previdenciárias, a empresa estrangeira assegurará ao trabalhador os direitos a ele conferidos neste Capítulo". À evidência, o capítulo mencionado é o III, da Lei n. 7.064/1982 e os direitos ali garantidos se referem à aplicação das leis do país da prestação de serviços, além de:

a) despesas de viagem de ida e volta do trabalhador ao exterior, inclusive a dos dependentes com ele residentes (art. 15);

b) limitação de até três anos para a permanência do trabalhador no exterior, salvo se assegurado a ele e a seus dependentes o direito de gozar férias anuais no Brasil, com despesas de viagem pagas pela empresa estrangeira (art. 16); 
c) segurança de retorno do trabalhador ao Brasil ao término do prazo de duração do contrato ou em caso de rescisão ou por motivo de saúde do trabalhador (art. 17); exigência de que a empresa estrangeira mantenha no Brasil procurador para representá-la com poderes de representação, inclusive para receber citação (art. 18);

d) fixação da responsabilidade solidária da pessoa jurídica domiciliada no Brasil com a empresa estrangeira por todas as obrigações decorrentes da contratação do trabalhador (art. 19).

Esse aspecto da lei exige buscar qual é o cenário jurídico previsto pelo legislador, no Capítulo III, da Lei n. 7.064/1982, para a aplicação da lei do local da prestação dos serviços, aos trabalhadores contratados sob essa conformação, em detrimento da lei mais favorável prevista no Capítulo II.

Logo, o estudo do conceito jurídico de empresa estrangeira trazido pela lei civil, combinado com os princípios de ampla proteção ao trabalhador contemplados no direito do trabalho, se reveste de fundamental importância para que se compreenda o verdadeiro alcance do Capítulo III da Lei n. 7.064/1982,

A teor dos arts. 1.134 a 1.141 do Código Civil, empresa estrangeira é aquela organizada sob as leis de outro país e com sede e administração fora do Brasil. Nas palavras de Maria Helena Diniz, “a nacionalidade da pessoa jurídica é conferida pela ordem jurídica estatal de sua constituição e pelo local de sua sede administrativa ou pelo centro decisório de exploração de suas atividades, pouco importando a nacionalidade dos sócios ou fundadores". 281

Nessa conformação, poderá contratar local para trabalhar a seu serviço no exterior, mediante autorização do Ministério do Trabalho e Emprego, por meio da comprovação de que se trata de "empresa (estrangeira) de cujo capital participe, em pelo menos $5 \%$ (cinco por cento) pessoa jurídica domiciliada no Brasil, conforme a regra do art. 13, do Capítulo III, da Lei 7.064/82”.

281 Maria Helena Diniz, Curso de direito civil brasileiro: direito de empresa, p. 519. 
Como se vê, o Capítulo III da Lei n. 7.064/1982 visa excepcionar a aplicação da lei mais favorável do Capítulo anterior do mesmo diploma legal, mas em hipótese muito restrita, a saber: quando se comprovar que uma empresa estrangeira, organizada, independentemente de sua sócia domiciliada no Brasil, deseja contratar trabalhador local para prestar serviços exclusivamente em seu favor, no exterior.

A participação de empresa brasileira no capital da estrangeira é o elemento de conexão a justificar o interesse da empresa daquela em contratar mão de obra local e legitimar o ajuste das condições de trabalho próprias do local da prestação de serviços.

Outro requisito diz respeito à nomeação de representante no Brasil. A regra decorre do art. 1.138 do $\mathrm{CC}$, segundo o qual a empresa estrangeira é obrigada a ter, permanentemente, representante no Brasil, com poderes para resolver quaisquer questões e receber citação judicial pela sociedade, previsão que também foi incluída no art. 18 da Lei n. 7.064/1982 com o intuito de prevenir que a empresa estrangeira se abstenha de responder a conflitos judiciais decorrentes da relação com o trabalhador contratado nos moldes do Capítulo III da Lei n. 7.064/1982.

Nessa conformação, temos que o art. 12 do Capítulo III se dirige especificamente à contratação por empresa estrangeira, ou seja, não se aplica, em geral, ao trabalhador com vínculo originário à empresa sediada no Brasil, a menos que se rompa o vínculo originário no Brasil.

Isso porque o trabalhador que mantém o vínculo com empresa sediada no Brasil se enquadrará em uma das modalidades de expatriação previstas no Capítulo II, que cuida especificamente da transferência de empregados quando o contrato estava sendo executado no território brasileiro (art. 2. ${ }^{\circ}, \mathrm{I}$ ), ou quando o empregado é cedido a empresa sediada no exterior, mantendo o vínculo trabalhista com o empregador brasileiro (art. $2 .^{\circ}$, II) ou contratado por empresa sediada no Brasil para trabalhar no exterior (art. 2. ${ }^{\circ}$, III).

A Portaria do Ministério do Trabalho e Emprego n. 21, de 09.03.2006, que regulamentou a matéria, prevê no art. $2^{\circ}{ }^{\circ}$, os requisitos a serem cumpridos pela empresa estrangeira, sediada no exterior, para a concessão da autorização ao pedido de contratação. Confira-se: 
Art. 2. ${ }^{\circ} \mathrm{O}$ pedido de autorização deverá ser formulado pela empresa interessada à Coordenação-Geral de Imigração, em língua portuguesa, e instruído com os seguintes documentos:

I - comprovação de sua existência jurídica, segundo as leis do país no qual é sediada, consularizada e traduzida para a língua portuguesa, por tradutor oficial juramentado;

II - comprovação de participação acionária em empresa brasileira, de, no mínimo, cinco por cento de seu capital social integralizado;

III - constituição de procurador no Brasil, com poderes especiais de representação, inclusive o de receber citação; e

IV - contrato individual de trabalho, em língua portuguesa, contemplando os preceitos da Lei 7.064, de 1982

Parágrafo único. A empresa brasileira de que trata o inciso II deste artigo responderá solidariamente com a empresa estrangeira pelos encargos e obrigações decorrentes da contratação do trabalhador.

Sucede, assim, que a lei especial, regulamentada pela Portaria n. 21/2006, dá suporte a pedidos para a contratação de mão de obra local para trabalhar em quaisquer empresas no exterior, desde que formulados em nome de empresa sediada no exterior, com a comprovação de que possui uma sócia no Brasil, com a participação em seu capital social de no mínimo $5 \%$.

Nota-se que não há vedação expressa na lei sob comento de que tais empresas estrangeiras contem com a participação de empresas brasileiras mediante participação societária maior do que 5\%. A lei sob comento nada dispõe sobre a forma de constituição da empresa estrangeira, todavia o espírito da lei leva a concluir que a estrangeira há que se constituir de forma juridicamente independente de sua sócia domiciliada no Brasil.

Do contrário, se estiver organizada na forma de filial, agência, sucursal ou subsidiária de empresa domiciliada no Brasil, há riscos de que o empregado contratado na estrangeira se subordine ao cumprimento de ordens emanadas diretamente da empresa no Brasil. À evidência, o empregado trabalhará a serviço da sede localizada no Brasil, atraindo o risco de incidência das normas do Capítulo II.

Há precedentes no Tribunal Superior do Trabalho exatamente nesse sentido, ou seja, reconhecendo o vínculo empregatício diretamente com a empresa brasileira, com a exclusão da aplicação do Capítulo III da Lei n. 7.064/1982, conforme se confere dos acórdãos a seguir reproduzidos: 
I - Agravo de instrumento da 2. ${ }^{\text {a }}$ reclamada, Petrobras Internacional S.A. - Braspetro

1 - Ilegitimidade passiva

Aduz a recorrente que não integra o mesmo grupo econômico que a $1 .^{\mathrm{a}}$ reclamada e que o fato de uma empresa pública ser controladora e acionária de outra não a torna responsável pelas obrigações por ela assumidas tampouco o fato de a União ser a sócia majoritária.

Assevera que inexiste dispositivo legal que respalde o entendimento do Regional, razão pela qual foi maculado o artigo $5 .^{\circ}$, II, da Constituição Federal.

Esta Corte na esteira da jurisprudência do Excelso Pretório, tem entendido que a violação ao artigo 5. ${ }^{\circ}$, II, da Constituição da República, por se tratar de norma genérica, somente seria possível de forma reflexa por violação à norma infraconstitucional, pelo que incólume o dispositivo constitucional invocado, não merecendo processamento o apelo.

Nego provimento.

2 - Responsabilidade solidária

Afirma a agravante que foi violado o artigo $2 .^{\circ}, \S 2 .^{\circ}$, da CLT, vez que na hipótese dos autos não restou evidenciado que uma das empresas esteja sob a direção, controle ou administração da outra, para configuração do grupo econômico.

O TRT da 1. . Região assim se pronunciou, à fl.178:

[...] Cabe ainda observar que é notório a formação de grupo econômico, sendo a primeira ré (Brasoil) subsidiária da segunda reclamada, empresa nacional (Braspetro).

Pelas próprias alegações da reclamada verifica-se de pronto que o recurso não se veicula, porquanto para se chegar à conclusão diversa da do Regional seria necessário revolver as provas e fatos dos autos, o que encontra óbice na Súmula 126 desta Corte.

Nego provimento.

3 - Declaração de vínculo com sociedade de economia mista. Ofensa ao artigo 37, II, da Constituição Federal

Alega a agravante que na verdade o autor pretende reconhecimento de vínculo de emprego com uma sociedade de economia mista e, portanto, ente da administração pública indireta, para a qual jamais prestou concurso público. Aponta afronta ao artigo 37, II, da Constituição Federal e dissenso pretoriano.

O recurso não se viabiliza, haja vista que conforme registrou o TRT de origem, o reclamante foi admitido antes da promulgação da Constituição Federal de 1988, período em que não existia vedação para contratação sem concurso público.

II - Agravo de instrumento da $1 .^{\text {a }}$ reclamada, Braspetro Oil Services Company - Brasoil

1 - Conflito de leis do trabalho no espaço. Lei 7.064/82. Alega a recorrente que, ao contrário do que constou do despacho denegatório, a decisão hostilizada violou o artigo 14 da Lei 7.064/82, porquanto a 
controvérsia gravita em torno da lei a ser aplicada na hipótese de trabalhador contratado por empresa estrangeira para laborar no exterior.

Assevera que é empresa constituída sob as leis das Ilhas Cayman cuja atividade-fim é a exploração de petróleo em diversas partes do mundo, pelo que deve ser observada a legislação vigente no país da prestação de serviços. Aponta contrariedade ao Enunciado 207 do TST. Transcreve arestos para demonstrar o dissenso.

A respeito do tema assim se pronunciou o Regional, às fls.178/79:

[...] Quanto ao contrato celebrado inicialmente com a Petrobras Internacional Braspetro, não há dúvida quanto à lei a ser aplicada, pois contratado o reclamante para laborar em solo brasileiro.

No que tange ao contrato celebrado com a Braspetro Oil Services Company Brasoil, foi o autor contratado no Brasil para laborar na Líbia, pendendo a controvérsia sobre qual a lei a ser aplicada.

Segundo o Enunciado 207 do C.TST, aplica-se a lei do local da prestação de serviços, princípio da lex loci executionis, seguindo o que dispõe o artigo 198 do Código de Bustamante que é territorial a legislação de proteção social ao trabalhador.

Porém, tratando-se de brasileiro contratado por ...empresa estrangeira, de capital nacional, pertencente ao Grupo Petrobrás..., conforme consta no parecer do ilustre representante do Ministério Público às fls. 515, deve ser aplicada a norma mais favorável (inciso II, artigo $3 .^{\circ}$, da Lei 7.064/82), que no caso é a brasileira, afastando assim, o princípio da lex loci executionis, reproduzido pelo artigo 14 da referida lei.

Vale transcrever a decisão proferida nos autos do Processo n. TST-RR376.707/97, da 3. ${ }^{a}$ turma do C.TST, Ministra-Relatora Maria Cristina Irigoyen Peduzzi, publicado no $D J$ em 05.04.2002, que trata de idêntica matéria, verbis:

...(omissis)... Processo: AIRR 161940-86.1991.5.01.0017, j. 29.06.2005, Rel. Juiz Convocado: Luiz Ronan Neves Koury, 3. ${ }^{a}$ Turma, DJ 26.08.2005.

1.5 - Adicional de transferência.

Alega a Recorrente que o Reclamante não era seu empregado, não se podendo falar em cessão para ir trabalhar na Guiana Francesa. Traz um aresto para o confronto e aponta violação do art. 2. ${ }^{\circ}$, II, da Lei 7.064/82.

Colhe-se do acórdão recorrido que a Reclamada ora recorrente foi considerada a real contratante do Reclamante, ficando evidenciada a cessão do obreiro para a empresa sediada no estrangeiro.

Fácil deduzir daí a ocorrência de fundamentação que se reporta ao contexto probatório, insuscetível de reexame em sede de revista, a teor do Enunciado n. 126, a partir do qual é inviável se cogitar da alegada violação do art. 2. ${ }^{\circ}$, II, da Lei 7.064/82. Processo: RR 36012448.1997.5.01.5555, j. 13.09.2000, Rel. Min. Antônio José de Barros Levenhagen, $4{ }^{\mathrm{a}}{ }^{\text {Turma, }}$ DJ 06.10.2000. ${ }^{282}$

282 Disponível em <https://aplicacao5.tst.jus.br/consultaProcessual/consultaTstNumUnica.do? consulta $=$ Consultar \&conscsjt $=\&$ numeroTst $=360124 \&$ digitoT $\mathrm{st}=48 \&$ anoT $\mathrm{st}=1997 \&$ orgaoTst $=5 \&$ tribuna 1Tst=01\&varaTst=5555> Acesso em 09 ago. 2013. 
Do exposto, os seguintes requisitos são necessários para a contratação de trabalhadores na modalidade contemplada no Capítulo III:

a) contratação de trabalhador por empresa genuinamente estrangeira;

b) a empresa estrangeira deve possuir uma sócia domiciliada no Brasil, que detenha pelo menos $5 \%$ de seu capital, e aqui nomear um representante com poderes de representação;

c) é condição para a contratação de trabalhador nos moldes do Capítulo III que o trabalho se desenvolva exclusivamente para empresa estrangeira no exterior, com o fito de prevenir risco de incidência de um contrato de trabalho único;

d) a remessa de executivos de uma empresa para outra, integrantes do mesmo grupo econômico, permanecendo a subordinação do trabalhador à empresa sediada no Brasil, atrai o cumprimento das regras do Capítulo II da Lei n. 7.064/1982.

Por fim, vale ressaltar que a lei previu a solidariedade entre a empresa estrangeira e sua sócia brasileira, pelas obrigações trabalhistas inadimplidas (art. 19, do Capítulo III, da Lei n. 7.064/1982), medida que se amolda perfeitamente aos princípios do direito do trabalho e nos conduz à análise do grupo econômico, na dicção do art. $2 .^{\circ}, \S 2 .^{\circ}$, da CLT:

Art. $2 .^{\circ}[\ldots]$

$\S 2 .^{\circ}$ Sempre que uma ou mais empresas, tendo, embora, cada uma delas, personalidade jurídica própria, estiverem sob a direção, controle ou administração de outra, constituindo grupo industrial, comercial ou de qualquer outra atividade econômica, serão, para os efeitos da relação de emprego, solidariamente responsáveis a empresa principal e cada uma das subordinadas.

\subsubsection{Outras questões controvertidas na Lei $n$. 7.064/1982}

Em relação à derrogação do princípio da lei da execução do contrato, pelo cancelamento da Súmula 207 do TST, a Lei n. 7.064/1982 dispõe especificamente sobre a 
incidência da lei brasileira quando mais favorável, de forma que implica derrogação parcial da aplicação da lei do local da execução do contrato.

Todavia, identificamos situações em que esse diploma legal se mostrará ineficaz e incompatível com a forma de migração.

Elucidamos com algumas hipóteses:

a) Transitoriedade da prestação de serviços em diversos países: ao trabalhador contratado pela matriz no Brasil ou no exterior, quando transferido de forma transitória para outras unidades da empresa, permanecendo por algum tempo, fixando ou não residência, e em seguida seguindo para outros países, mantendo-se subordinado à matriz ou a outra unidade específica, o contrato não poderá materialmente se submeter à lei do local da prestação de serviços.

O trabalho se reveste de caráter itinerante e atrairá a aplicação da lei do país onde o empregado se mantiver vinculado por conta das características da prestação de serviços. Assim, entendemos que se aplicará a lei do país onde se situar a matriz ou a unidade na qual o empregado se mantiver subordinado de modo mais efetivo ao longo de sua prestação de serviços.

b) Nas transferências provisórias: anotamos que a transferência para a qual entendemos aplicar-se o Capítulo II, da Lei n. 7.064/1982, deve ser para outra filial, agência ou empresa do mesmo grupo econômico situada em outro país. Nessa hipótese, poder-se-á aplicar a legislação brasileira, caso se verificar mais favorável que a legislação do país de destino no conjunto de normas e em relação a cada matéria.

Para comparar distintas legislações, a teoria mais aceita na doutrina é a teoria intermediária, eclética ou orgânica, que determina a aplicação do conjunto de normas que for mais favorável ao trabalhador em detrimento daquela matéria prevista na legislação do país de origem. 
Entretanto, a Lei n. 7.064/1982, embora admita esse critério para a escolha da norma mais benéfica, exige que o comparativo também ocorra em relação a cada matéria. Assim, por exemplo, aplicar-se-á a um trabalhador transferido o capítulo da "remuneração" contido na norma estrangeira, se este fixar um salário mínimo muito superior ao salário do Brasil e, ao mesmo contrato, o capítulo da legislação brasileira que trata da indenização por tempo de serviço, se esta oferecer mais vantagens do que as previstas na legislação do país de destino, critério que praticamente inviabiliza qualquer comparativo.

Um ponto positivo a se destacar é a previsão do art. 10 da Lei n. 7.064/1982, que trata sobre a extinção dos benefícios após o término da expatriação.

Nesse particular, a lei traz segurança jurídica, posto que se contrapõe às recentes decisões da Justiça do Trabalho brasileira que consideravam indevida a supressão de verbas de caráter salarial ao retorno do expatriado ao argumento de que as vantagens concedidas ao expatriado que não se mostravam necessárias ao exercício do trabalho no exterior se revestiam do caráter de salário indireto, incorporando-se à remuneração do expatriado, pela habitualidade de seu pagamento, não sendo possível a sua supressão ao retorno do empregado.

É bem verdade que o empregador deverá zelar para que o contrato de expatriação e os documentos de que se compõe contenham a nomenclatura individualizada das verbas ajustadas para o período de expatriação, a sua justificativa em razão do trabalho a ser desenvolvido e a expressa previsão de sua supressão ao término do período previsto para a sua duração.

\subsection{Impactos das transferências no Fundo de Garantia do Tempo de Serviço (FGTS)}

Sob a égide de uma relação trabalhista, sob vínculo de emprego, iniciada no exterior, que posteriormente se desenvolve no Brasil, mediante a transferência internacional do trabalhador migrante entre empresas que integram o mesmo grupo econômico, não restam dúvidas de que o migrante terá direito à base mínima de proteção garantida pelo Direito do Trabalho e Constituição Federal. 
Logo, é direito do trabalhador migrante, enquanto prestar serviços no Brasil, ou do migrante contratado ou transferido provisoriamente a partir do Brasil, para o exterior, receber, em sua conta vinculada específica, os depósitos equivalentes do FGTS, no percentual de $8 \%$ sobre a remuneração paga ou devida no mês anterior, tal como dispõe o art. 15 da Lei n. 8.036/1990.

Todavia, tratando-se de contrato único o exemplo de que estamos cogitando, uma questão polêmica aflora em relação à incidência do FGTS sobre as verbas de natureza salarial que, porventura, continuem sendo pagas no país de origem do migrante, mesmo na hipótese de terem as partes ajustado suspensão ou interrupção daquele contrato original, durante o período de estada no Brasil.

No conjunto desses direitos, surge o debate em torno dos depósitos para o FGTS.

Para Arnaldo Süssekind, nas transferências de caráter provisório, assim entendidas aquelas em que o empregado permanece juridicamente vinculado ao estabelecimento que o enviou para prestar serviços em outro país, devem ser garantidos apenas os direitos trabalhistas mínimos, de ordem pública, em vigor no país de destino.

No entanto, segundo o mesmo autor, há uma pequena margem para a livre estipulação das disposições de direito privado, apesar do intervencionismo do Estado que impõe um mínimo de garantias de proteção ao trabalhador. Assim, acima do limite compulsório de proteção, o art. 444 da CLT permite a autonomia de negociação entre as partes. $^{283}$

A Instrução Normativa do Ministério do Trabalho e Emprego n. 25, de 20.12.2001, dispõe no art. 12, parágrafo único, II, sobre "a incidência do FGTS sobre o salário contratual e o adicional de transferência devido ao trabalhador contratado no Brasil e transferido para prestar serviço no exterior".

No mesmo sentido a Orientação Jurisprudencial do Tribunal Superior do Trabalho - OJ SDI1 n. 232 sinaliza que:

283 Arnaldo Süssekind. Conflitos de leis do trabalho, p. $43-47$. 
FGTS. Incidência. Empregado transferido para o exterior. Remuneração. O FGTS incide sobre todas as parcelas de natureza salarial pagas ao empregado em virtude de prestação de serviços no exterior.

O entendimento do Ministério do Trabalho e Emprego e da jurisprudência do TST refletem a previsão legal sobre o tema. De fato, tanto a Lei n. 5.107/1966 previa como a Lei n. 8.036/1990 estabelece que os depósitos de FGTS possuem como base de cálculo a remuneração paga ao empregado e não parte dela, ficticiamente estipulada como seu salário-base:

Art. 15 da Lei 8.036/1990:

Para os fins previstos nesta lei, todos os empregadores ficam obrigados a depositar, até o dia 7 (sete) de cada mês, em conta bancária vinculada, a importância correspondente a 8 (oito) por cento da remuneração paga ou devida, no mês anterior, a cada trabalhador, incluídas na remuneração as parcelas de que tratam os arts. 457 e 458 da CLT e a gratificação de Natal a que se refere a Lei n. 4.090, de 13 de julho de 1962, com as modificações da Lei n. 4.749, de 12 de agosto de 1965.

A tendência da jurisprudência produzida pela Justiça do Trabalho inspirou as autoridades públicas fiscalizadoras, sobretudo o Ministério do Trabalho e Emprego, a emitir normas administrativas que objetivaram interpretar o art. 15 da Lei n. 8.036/1990, reguladora do direito dos empregados ao Fundo de Garantia por Tempo de Serviço (FGTS).

Primeiramente, foi emitida a Nota Técnica n. 2, em 2005. Posteriormente, a Instrução Normativa n. 84, em 2010, mais explícita, impõe que a remuneração paga no exterior a empregado estrangeiro residente no Brasil deve ser considerada para efeito de cálculo da contribuição ao FGTS, equivalente aos depósitos de $8 \%$ sobre toda a remuneração mensalmente paga ao expatriado (no Brasil e no exterior) durante o período em que perdurar a expatriação.

Em meados de 2006, o Ministério retrocedeu e chegou a divulgar na imprensa que desistia de cobrar FGTS sobre a remuneração paga ao migrante no exterior, em atenção ao pleito da Confederação Nacional da Indústria (CNI) que liderou um grupo de várias empresas com o objetivo de apontar a ilegalidade da cobrança da parcela, sobretudo diante da falta de mecanismos para a operacionalização, uma vez que a parcela de salário 
paga no exterior não tramita em folha de pagamento local para que se tenha a base de cálculo necessária ao recolhimento das contribuições do FGTS. $^{284}$

No entanto, em 2010 o Ministério editou a Instrução Normativa n. 84, mediante a qual retomou o entendimento sobre a cobrança e tratou de criar mecanismos para contornar as dificuldades de operacionalização, a exemplo do código específico para o preenchimento da guia de recolhimento do FGTS - GFIP.

A mesma regra foi repetida na Instrução Normativa n. 99, de 23.08.2012, que em seu art. 8. ${ }^{\circ}$, parágrafo único, dispõe que na identificação da base de cálculo que devem ser considerados: ${ }^{285}$

III - o salário contratual e o adicional de transferência devido ao empregado contratado no Brasil e transferido para prestar serviços no exterior;

IV - a remuneração paga a empregado estrangeiro, em atividade no Brasil, independente do local em que for realizado o pagamento.

Nota-se, contudo, que a regra da IN n. 99 cria uma distinção entre a base de cálculo do FGTS do trabalhador estrangeiro quando a serviço no Brasil, garantindo-lhe os depósitos em relação à remuneração global, ou seja, a soma das parcelas remuneratórias pagas no Brasil e no exterior, enquanto para o empregado também transferido a partir do Brasil para prestar serviços no exterior a parcela incidirá sob o adicional de transferência, aquele previsto na Lei n. 7.064/1984, art. $4 .^{\circ}$, caput.

Essa parcela não existe para a hipótese de trabalhador migrante transferido do exterior para prestar serviço no Brasil, no que se cria uma diferenciação em favor do trabalhador que migra a partir do Brasil para o exterior, em detrimento do trabalhador que migra em sentido inverso.

Outra questão controvertida envolvendo a aplicação do FGTS ao trabalhador migrante se refere à rescisão do contrato de trabalho local do período de estadia no Brasil, no tocante à incidência ou não da multa rescisória de $50 \%$ sobre o saldo da conta

\footnotetext{
284 Disponível no boletim informativo Ernst \& Young “Tax View”, n. 1, p. 1-2, 2006. <http://www.ey.com.brltaxview2006>. Acesso em: 3 out. 2013.

285 Inteiro teor da IN n. 99 disponível em: <http://portal.mte.gov.brldatalfiles18A7C812D38CF4A 290139958EE0a\%20Normativa\%20(Fiscalização_FGTS\%20\%eCS).pdf>. Acesso em: 6 out. 2013.
} 
vinculada, na qual foram efetuados os depósitos de FGTS equivalente a $8 \%$ durante o período de serviços prestados no Brasil.

A dúvida diz respeito à incidência dessa multa nas hipóteses em que o contrato único terá continuidade mediante o retorno do migrante ao seu país de origem. É forçoso reconhecer um ponto de insegurança jurídica para as partes, eis que o saldo do FGTS somente poderá ser levantado pelo trabalhador migrante em três hipóteses: a) de rescisão por iniciativa do empregador, sem justa causa; b) de pedido de demissão; ou c) de término do contrato por prazo determinado.

As alternativas "a" e "b" não parecem refletir a realidade tampouco a razão para a qual a lei previu o levantamento do saldo da conta do FGTS pelo trabalhador: a rescisão por iniciativa do empregador, sem justa causa, ou o pedido de demissão, não implicará o desemprego do estrangeiro, caso o vínculo empregatício tenha continuidade, mediante o retorno do migrante ao seu país de origem ou a sua designação para prestar serviços em outros países.

Essas hipóteses nem sempre são as que motivam o retorno do migrante ao país de origem. Na maioria dos casos, trata-se de um estrangeiro sob vínculo de emprego por prazo indeterminado, em virtude de sua permanência ter sido planejada para durar mais de dois anos, excedendo, portanto, o período máximo para a utilização do contrato por prazo determinado (isso sem falar nas restrições à utilização do contrato por prazo determinado para a realização de atividades regulares do empregador). Logo, o trabalhador não poderá sacar o saldo do FGTS ao final do contrato de trabalho local.

O pagamento da multa rescisória ao final de um contrato local não parece ser a via mais apropriada, exceto se a rescisão ocorre em definitivo no Brasil. A alternativa de pedido de demissão por parte do trabalhador migrante, pela mesma razão de que ele retomará um vínculo estabelecido no país de origem, igualmente não corresponde à realidade. Ademais, sob essa modalidade de rescisão, o trabalhador migrante nem levanta o saldo do FGTS nem recebe a multa rescisória. Na prática, terá de esperar três anos, e, desde que não seja estabelecido nesse ínterim, nenhum vínculo de emprego no Brasil, para que então possa sacar o saldo do FGTS (Lei n. 8.036/1990, art. 20, VIII). 
Nessa perspectiva, a nosso ver a legislação do FGTS carece de reforma para se adequar à realidade.

\subsection{Benefícios ou ajudas de custo ajustadas contratualmente}

O pagamento de benefícios contratualmente ajustados entre migrantes e seus respectivos empregadores é causa de intensas discussões e, não raro, deságuam em onerosas contingências financeiras para as empresas.

Sob a perspectiva do Direito do Trabalho, a incidência ou não do FGTS e de outros encargos trabalhistas sobre benefícios avençados no contrato de trabalho sob vínculo empregatício, a exemplo do veículo, telefone celular, aluguel/auxílio-moradia, dependerá de dois aspectos: (a) a interpretação do conceito de remuneração; (b) o histórico praticado pelo empregador em relação aos atuais empregados no que diz respeito ao FGTS.

Quanto à interpretação do conceito de remuneração, o art. 457 da CLT dispõe que são considerados no salário não só a importância estipulada como pagamento pelos serviços prestados, como também as comissões, as percentagens, as gratificações, os abonos e, inclusive, o pagamento de despesas pessoais do empregado. Ora, tratando-se de moradia, por exemplo, o conceito dado pela CLT é amplo e não permite identificar com precisão se o valor subsidiado pela empresa em favor do empregado é ou não necessário à realização do trabalho.

Assim, pode-se chegar à conclusão de que qualquer cidadão comum deve arcar com o custeio de sua residência. Logo, sob esse aspecto, se o empregador assume esse custo pessoal do trabalhador, atrai o conceito de salário indireto e consequentemente a obrigação de efetuar os depósitos do FGTS.

No entanto, em relação ao migrante, há uma peculiaridade: a nova moradia nos país em que o empregado residirá temporariamente objetiva atender aos interesses da empresa. Representa, portanto, um custo que o trabalhador não desejou assumir espontaneamente. Ele o fará, assim, em razão direta da necessidade de assumir o posto de trabalho oferecido. 
Nessa perspectiva, a finalidade da residência temporária no exterior decorre, a nosso ver, da necessidade da prestação de serviços, de modo que essas despesas encontram espaço para serem suportadas pela empresa, pois atreladas às necessidades de trabalho durante a transferência - desde que pagas em valores razoáveis em relação ao custo de vida do país de destino - de modo que se tornem hábeis a justificar sua natureza indenizatória, bem como viabilizar a supressão ao término da expatriação, sem confundi-las com direitos adquiridos ao longo da carreira do expatriado no grupo de empresas.

Esse cuidado tem sido valorizado nas mais recentes decisões proferidas em ações individuais ajuizadas por trabalhadores pleiteando o cômputo de aluguel como salário. Veja-se, nesse sentido, trecho de decisão na qual entendeu o juiz relator em considerar como verba indenizatória o valor pago pelo empregador a título de aluguel, em valor correspondente a essa despesa necessária para a realização do trabalho:

\begin{abstract}
Embora seja possível vislumbrar, a partir da leitura dos documentos internos disciplinadores do benefício em questão, que o empregador tinha realmente o objetivo de suprir os gastos do empregado com moradia, não há desconsiderar que o auxílio-aluguel/moradia consistia também espécie de estímulo para que o trabalhador atuasse no exterior. Nada obstante, consideradas as circunstâncias apreendidas, penso razoável concluir que a parcela possuiu dupla natureza: até o montante destinado ao efetivo pagamento das despesas de aluguel do autor, revestiu-se de caráter nitidamente indenizatório; já os valores que excedem o gasto com moradia encerraram índole puramente salarial. Desse modo, a parte do auxílio aluguel/moradia efetivamente utilizada pelo Reclamante para fazer face às despesas com aluguel é regida pela disciplina do art. 457, § 2. ${ }^{\circ}$, da CLT, mostrando-se indispensável para a realização do trabalho (Súmula n. 367 do C. TST). Diferentemente, porém, a quantia que superava os gastos do Recorrido com habitação encontra disciplina no caput do art. 457 da CLT, eis que evidente o escopo de remunerar a "[...] dignidade mínima inerente à função" (fl. 1.052), classificada pelo Recorrente como relevante (TST, 3. ${ }^{\mathrm{a}}$ Turma, RR 51300-47.2007.5.10.0003 j. 07.03.2012, Rel. Juiz Convocado Flavio Portinho Sirangelo, DEJT 16.03.2012).
\end{abstract}

Entendimento idêntico foi proferido em julho de 2011, em decisão do Tribunal Regional Federal da 4. ${ }^{a}$ Região, abaixo reproduzida:

1. O auxílio-moradia, recebido por força de mudança de domicílio imposta pelo empregador para outra cidade, por necessidade do serviço, tem natureza indenizatória. 2. A natureza indenizatória da referida verba, percebida por servidores públicos, já foi reconhecida em precedentes do Superior Tribunal de Justiça. 3. Tal entendimento deve ser aplicado, igualmente, aos empregados da iniciativa privada, em razão do princípio 
da isonomia (art. 5. ${ }^{\circ}$ da Constituição Federal). Incidente improvido (TRF4, Incidente de uniformização JEF n. 0018398-95.2007.404.7050, Turma Regional de Uniformização, Juiz Federal Antonio Fernando Schenkel do Amaral e Silva, por maioria vencida a Relatora, $D E$ 25.07.2011). ${ }^{286}$

Entretanto, ocorre que esse recente posicionamento da Justiça do Trabalho não contribui para solucionar a situação em que depósitos do FGTS já foram reiteradamente realizados ao longo do tempo sobre tais benefícios, em especial sobre o valor do aluguel pago ou subsidiado pelo empregador em favor do empregado. Segundo os princípios vigentes no Direito do Trabalho brasileiro, o peso da habitualidade no pagamento da verba impedirá a supressão dos encargos trabalhistas.

Quando o empregador paga determinada verba de forma repetida e habitual, a prática se reflete na vedação à supressão da verba. Toda alteração de condições de trabalho estabelecidas em decorrência da habitualidade com que são praticadas pelo empregado se defrontará com sérias barreiras à sua plena eficácia perante as autoridades fiscalizadoras.

A supressão esbarra nas regras de proteção aos trabalhadores dispostas nos arts. 9..$^{\circ}$ e 468 da CLT. Em suma, à luz do art. 9. ${ }^{\circ}$, será considerado nulo de pleno direito o ato que impedir os empregados de usufruírem dos depósitos do FGTS tradicionalmente garantidos sobre o aluguel/auxílio-moradia. As disposições do art. 468, caput, igualmente inibem a iniciativa de alterar a atual regra instituída sobre os depósitos fundiários, pois veda alterações de condições de trabalho que resultam em prejuízos financeiros aos empregados afetados.

Do exposto, também sob esse aspecto, o arranjo jurídico envolvendo o trabalhado migrante necessita de revisão.

\subsection{1 "Localização" do contrato de trabalho}

Um ponto de preocupação diz respeito à ocorrência da consolidação da transferência que se iniciou sob um caráter provisório e, posteriormente, em dado

286 Disponível em: <http://www2.trf4.jus.br/trf4/controlador.php?acao=consulta_processual_resultado_ pesquisa\&selForma=NU\&txtValor $=200571000198800 \& \mathrm{chkMostrarBaixados=S \& selOrigem=TRF \& hdn}$ RefId=217ae3449527c40387fb340b33015a0b\&txtPalavraGerada=FZ>. Acesso em: 20 set. 2013. 
momento, se verifica permanente. A questão é identificar se seria possível definir um dado momento como um marco para delimitar a interrupção da regência do contrato de trabalho como internacional.

A aplicação da Lei n. 7.064/1982, sobretudo o Capítulo II, poderá dar um norte à nova política migratória nesse aspecto, na medida em que prevê que a existência de um contrato de transferência internacional que foi ajustado de forma autônoma entre as partes e prevalecerá durante o período ajustado. Portanto, a rigor, o contrato internacional perdurará pelo período que as partes o fixaram, a significar que, em dado momento, poderá se converter em um contrato local, regido exclusivamente pela lei do local de prestação dos serviços.

É bem verdade que o princípio da autonomia da vontade das partes não é absoluto e poderá trazer alguma insegurança jurídica, sobretudo ao empregador, em caso de conflitos sobre as regras de direito aplicáveis ao caso concreto.

Por exemplo, se a execução do contrato se prolonga além do prazo fixado pelas partes, sem alterações, é assegurada ao trabalhador a manutenção das condições mais benéficas. Aliás, o princípio da ampla proteção do trabalhador é assegurado internacionalmente. Nesse sentido, o $§ 1 .^{\circ}$ do art. $6 .^{\circ}$ da Convenção de Roma impõe que a escolha pelas partes da lei aplicável não pode ter por resultado privar o trabalhador da proteção da lei mais favorável.

Considerando o até aqui exposto, temos que, para que o empregador, no exterior, possa, a partir do término do prazo da expatriação, aplicar ao expatriado as condições de um contrato local, há que se perquirir de que forma se deu a transferência. Se houve a manutenção do vínculo no país de origem, o ideal seria operar a rescisão primeiramente na empregadora originária, em documento que, por ter reflexos no país de destino, seria também assinado pela unidade deste país.

Uma vez encerrada formalmente a relação original, desde que de boa-fé, tem-se interrompida a contagem do tempo de serviço prestado no Brasil, conforme prevê o art. 453 da CLT, segundo o qual "no tempo de serviço do empregado, quando readmitido, serão computados os períodos, ainda que não contínuos, em que tiver trabalhado 
anteriormente na empresa, salvo se houver sido despedido por falta grave, recebido indenização legal ou se aposentado espontaneamente.

Encerradas as relações de trabalho anteriores no país de origem e de destino, na forma indicada, poder-se-á ter um novo contrato.

Como se vê do exposto, também sob essa perspectiva há que se revisar a legislação trabalhista aplicada ao migrante.

\subsection{Previdência social e acordos internacionais}

As primeiras iniciativas dos Estados em estabelecer regimes de seguridade social pela via dos acordos internacionais precedem à Segunda Guerra Mundial, época em que se tem notícia de acordos avençados entre países da Europa Ocidental. ${ }^{287}$

A crescente consciência da necessidade de uma proteção social adequada aos trabalhadores migrantes vem propiciando um aumento considerável no número de acordos bilaterais entre países emissores e receptores de migrantes, com regras que buscam aproximar o tratamento do migrante àquele desfrutado pelo cidadão nacional, nos moldes preconizados pela Convenção n. 118, da OIT, que prevê tratamento igualitário entre nacionais e estrangeiros em matéria de previdência social.

Pautados nos princípios de igualdade, solidariedade e universalidade, os acordos de seguridade social objetivam eliminar as cláusulas que vinculam a aquisição de determinado benefício à residência no país contratante e evitar a dupla contribuição e dupla cobertura por parte do migrante, o que ocorre em relação aos dois países acordantes.

Os acordos internacionais de seguridade social firmados pelo Brasil são conduzidos pelo Ministério das Relações Exteriores, porém a competência para a celebração, acompanhamento e operacionalização é da Assessoria de Assuntos Internacionais, órgão do Ministério da Previdência Social e Assistência.

287 Orlando de Araujo, O trabalhador global e a previdência: reflexões sobre um direito humano em crise, p. 168-169. 
Atualmente o Brasil firmou acordos bilaterais com dez países: Luxemburgo, Espanha, Ilha de Cabo Verde, Itália e Paraguai, Uruguai, Chile, Argentina, Portugal, Grécia e Alemanha. Existem acordos bilaterais aguardando aprovação pelo Congresso Nacional: Bélgica, Canadá, Coreia, França, Quebec, Alemanha e Japão. Há, ainda, dois tratados multilaterais: o Acordo Multilateral do Mercosul, firmado entre o Brasil, Argentina, Paraguai e Uruguai, e o Acordo de Aplicação da Convenção Multilateral Líbero-Americana de Seguridade Social, o qual já está em vigor para os seguintes países: Bolívia, Brasil, Chile, Equador, Espanha, Paraguai e Uruguai. ${ }^{288}$

Esses acordos internacionais tratam de regras específicas de custeio do sistema previdenciário durante o período de transferência provisória do trabalhador migrante para o território de um dos países acordantes, além de possibilitar a manutenção da condição de segurado perante o sistema previdenciário e recebimento de eventuais benefícios.

Objetivam, em geral, beneficiar o trabalhador migrante, estabelecendo um conjunto de benefícios previdenciários que será disponibilizado ao trabalhador durante a migração para um dos países signatários, além de regular as contribuições de forma evitar a dupla tributação para o migrante e permitir a totalização dos períodos de contribuição efetuados em um e outro país, para fins de elegibilidade aos benefícios previdenciários, sobretudo a pensão por aposentadoria, embora nem todos os acordos estabeleçam igualdade de condições entre os nacionais e os estrangeiros.

Assim, a sistemática adotada nos acordos permite ao empregado transferido escolher em qual país - de origem ou de destino - pretende contribuir durante a transferência internacional. Ao final, o período e os valores serão considerados por ambos os países para fins de benefícios da aposentadoria, conforme as regras de cada país.

A contagem recíproca do tempo de contribuição é um dos pontos positivos dos Acordos, uma vez que permite, durante o período de expatriação, que o migrante contribua para o regime previdenciário do país de origem ou do destino e seja qual for o país escolhido o migrante usufruirá da contagem recíproca de tempo nos regimes de seguridade

288 Disponível em: <http://www.Previdência.gov.brla-previdencialassuntos-internacionais-acordosinternacionais-portugues〉. Acesso em: 6 out. 2013. 
social de ambos os países acordantes. Essa possibilidade é concretizada mediante emissão da certidão de tempo de serviço prestado em um dos países acordantes.

Quando um trabalhador se desloca para um país que não possui acordo com o Brasil, com a extinção do vínculo de emprego previamente ao deslocamento, uma das orientações do Ministério da Previdência é que o trabalhador contribua para a Previdência brasileira como segurado facultativo. Mesmo no exterior, ele poderá continuar colaborando para prevenir perder qualidade de segurado aqui no Brasil.

Portanto, conforme destaca Spada, no tocante à territorialidade da legislação previdenciária, a regra do art. 5. ${ }^{\circ}$ da Lei n. 8.212/1991 implica reconhecer que

[...] são segurados obrigatórios todos os que trabalham como empregados, no território nacional e os brasileiros ou estrangeiros, com domicílio no território nacional, que tenham sido contratados no Brasil por empresas nacionais para trabalhar em filiais ou agências situadas em território estrangeiro, de forma a evitar prejuízos aos empregados. ${ }^{289}$

O princípio da territorialidade também atrairá obrigações para as empresas. No que diz respeito às contribuições da empresa para o sistema brasileiro, a legislação obriga ao recolhimento das parcelas previdenciárias incidentes sobre as verbas de caráter remuneratório pagas ao expatriado no Brasil e no exterior, pois os acordos não implicam a modificação da legislação interna, cabendo a cada país contratante.

É assim porque a obrigação previdenciária ao custeio do modelo de previdência social brasileira estabelecida na forma art. 15, inciso I, da Lei n. 8.212/1991 incide expressamente sobre a empresa, assim entendida a firma individual ou sociedade que assume o risco da atividade econômica urbana ou rural, com fins lucrativos ou não, nem como os órgãos e entidades da administração direta, indireta e fundacional.

O sistema de seguridade social brasileiro é, como destacam Castro e Lazzari, puramente contributivo, dependente das contribuições sociais destinadas ao custeio do sistema. No que se refere às contribuições das empresas, a Constituição Federal estabelece no art. 195, inciso I, que as contribuições incidem sobre a folha de salários e demais

289 Carolina Benedet Barreiros Spada, Contribuição previdenciária devida sobre as verbas trabalhistas pagas aos empregados transferidos para o exterior: Lei 11.962/2009, p. 52. 
rendimentos do trabalho pagos ou creditados, pela empresa, a qualquer título, à pessoa física que preste serviços. ${ }^{290}$

A cobrança é efetivada conforme o inciso I do art. 22 da Lei n. 8.212/1991, na alíquota de $20 \%$ sobre o total das remunerações pagas, devidas ou creditadas a qualquer título, durante o mês, aos segurados empregados e trabalhadores avulsos que lhe prestem serviços, destinados a retribuir o trabalho. Outras contribuições incidirão, ainda, para o financiamento dos riscos ambientais do trabalho (RAT), para a contribuição para o financiamento da aposentadoria.

No entanto, a questão envolvendo a incidência da contribuição da empresa sobre as parcelas remuneratórias pagas ao migrante é sem dúvida a que gera mais polêmica. Sendo a empresa brasileira parte do mesmo grupo econômico da empresa que receberá o empregado, haverá a configuração da figura do empregador único, o que significa que existirá apenas um contrato de trabalho vigente durante o período de expatriação para o país estrangeiro, atraindo para a empresa localizada no Brasil a obrigação de proceder ao recolhimento das contribuições previdenciárias devidas sobre o total da remuneração aferida pelo trabalhador transferido, seja sobre as verbas pagas no Brasil, seja sobre as verbas pagas no exterior.

As hipóteses de não incidência dependem da comprovação da extinção do vínculo trabalhista com o empregado brasileiro de forma lícita, sem evidências de que se buscou, mediante a rescisão, evitar encargos trabalhistas.

Não sendo essa a hipótese, temos que toda empresa sediada no Brasil que receber migrantes e não romper seus vínculos com outras empresas sediadas no exterior, como resultado de transferência intraempresa, se submeterá ao conceito do contrato único. Portanto, se os migrantes continuarem a receber salário da fonte pagadora localizada no exterior, enquanto executam a prestação de serviços no Brasil, os valores pagos pela empresa estrangeira também integrarão a folha de salários da empresa brasileira, para fins de recolhimento da contribuição da empresa para o custeio da previdência brasileira.

290 Carlos Alberto Pereira de Castro e João Batista Lazzari, Manual de direito previdenciário, p. 253-255. 
Nesse mesmo sentido caminha a jurisprudência do Tribunal Regional Federal da 3. ${ }^{a}$ Região, a exemplo da decisão proferida em Apelação Civil interposta por empresa que propugnava pela isenção das contribuições previdenciárias sobre os pagamentos remuneratórios efetuados no exterior, em favor de migrante, durante o período de prestação de serviços no Brasil, que foi negada pela Juíza Relatora, Desembargadora Federal Vesna Kolmar, sob os seguintes argumentos:

[...] O contrato firmado no exterior com a matriz não subsiste à transferência do empregado para o Brasil. Inexistência de dualidade de contratos. Eventual obrigação que o empregado expatriado mantém com a empresa do país de origem é decorrente do mesmo contrato executado no novo local de trabalho. Se a prestação de serviços é efetuada no Brasil, o contrato de trabalho se sujeita às regras da legislação brasileira, ainda que parte do pagamento seja efetuado no exterior pela empresa americana, uma vez que remunera a prestação de serviços realizada aqui. Incidência da contribuição social sobre o total recebido pelas duas empresas. Exigibilidade da contribuição sobre os valores pagos a título da verba denominada Gross up. Ainda que tal verba tenha por escopo compensar o empregado expatriado pelo gasto a maior com tributos do que aquele que despenderia se em seu país de origem estivesse, compõe parcela do salário do empregado, posto que têm caráter de habitualidade e é paga em decorrência do próprio contrato de trabalho, seja por força de acordo ou por liberalidade do empregador a fim de tornar a transferência do trabalhador mais atrativa. Inteligência do art. 457, § 1. , da CLT. Preliminar rejeitada e, no mérito, recurso parcialmente provido apenas para reduzir a condenação em honorários (Tribunal Regional Federal da 3. ${ }^{a}$ Região--SP, Apelação Cível n. 003368485.2004.4.03.6100/SP, Apelante: Monsanto do Brasil Ltda.; Apelado União Federal (Fazenda Nacional). Entidade: Instituto do Seguro Social - INSS. DE 05.12.2012. ${ }^{291}$

Trata-se de legislação voltada à proteção do trabalhador local, contratado no Brasil (brasileiro ou estrangeiro residente), que todavia peca ao não distinguir entre os vários cenários possíveis para a mobilidade de profissionais ao redor do mundo. Portanto, a postura da empresa no que diz respeito ao FGTS e à previdência social merecerá uma reavaliação, como adiante se verá.

291 Disponível em: <http://web.trf3.jus.br/acordaos/acordao/buscardocumentogedpro/2411502>. Acesso em: 22 out. 2013. 


\section{Capítulo 4 \\ CONTRIBUIÇÕES PARA UM PROJETO HUMANÍSTICO NA POLÍTICA DE MIGRAÇÃO A TRABALHO BRASILEIRA}

De maneira geral, analisando-se as experiências estrangeira e brasileira nas políticas migratórias, foi possível concluir que os países convivem com uma força irresistível: a economia a impulsionar o movimento de pessoas em resposta à oferta de melhores oportunidades de trabalho. Há sempre um fluxo natural de pessoas atraídas por melhores oportunidades para si e para seus familiares, o que explica o desejo de viver e trabalhar nos Estados Unidos, em vez do leste europeu ou do continente africano.

As políticas migratórias exercem, como demonstramos no Capítulo 2, um papel de constante resistência, o qual exercem mediante a limitação do número de migrantes, do controle da composição destes fluxos, da seleção dos migrantes mais qualificados em detrimento dos migrantes de baixa qualificação.

Em consequência, pressionam os indivíduos a se valerem de canais migratórios ilegais, acarretando resultados ainda piores tanto aos países quanto aos indivíduos.

A insistência nesse ciclo vicioso é identificada por Pritchett como o resultado catastrófico de ideias desenvolvidas com o foco único de atender um determinado padrão de "imigração perfeita" definido com base nos interesses do Estado. ${ }^{292}$

Esse padrão foi identificado em maior ou menor grau nos países estudados no Capítulo 2 e permeia todos os blocos de integração pesquisados: União Europeia, Nafta e Mercosul.

Esse conceito de população de estrangeiros desejada por determinado país, segundo o autor, equivaleria ao número máximo de pessoas que poderiam viver em determinado espaço territorial, de acordo com as expectativas que esse Estado traçou para a sua própria economia, incluindo políticas públicas, institucionais e tecnológicas. Essa visão centrada nos interesses locais varia evidentemente conforme o país, e poderá variar

292 Lant Pritchett, Let their people come: breaking the gridlock on international mobility, p. 105. 
em relação ao mesmo país, quando confrontado com alterações não planejadas. Exemplos clássicos de alterações bruscas nos padrões migratórios são identificados como desastres econômicos e conflitos armados.

Embora essa forma de manejo da política migratória se apresente bem conveniente para os Estados ricos, que involuntariamente são receptores de um enorme contingente de migrantes a trabalho, resulta condenável ao desconsiderar os compromissos internacionais assumidos em prol da ampliação e da efetivação dos direitos humanos dos migrantes, na concepção com a qual foram apresentados no Capítulo 1 deste estudo.

Dito isso, apresentamos alguns caminhos para discussão de um projeto humanístico da política migratória a trabalho brasileira, como segue.

\subsection{Cooperação entre países}

A nacionalidade e a cidadania, a nosso ver, constituem uma barreira intransponível para o reconhecimento pleno dos direitos dos estrangeiros. A vulnerabilidade dos migrantes está no fato de que não têm o poder de movimentar as estruturas sociais dos Estados e toda e qualquer crise econômica resulta em sacrifícios dos direitos dos estrangeiros em prol do exercício da soberania do país de destino dessas pessoas.

Nessa perspectiva, os direitos dos migrantes só encontram respaldo por meio de mecanismos internacionais que atendem melhor o seu papel de reformadores sociais do que a atuação das políticas migratórias a trabalho isoladas nas fronteiras dos países receptores.

Assim sendo, defendemos a cooperação entre os países de origem e de destino na regulamentação dos fluxos de migração. Nesse sentido, concordamos com Patarra, na aposta da transição das políticas migratórias de controle para as políticas de gestão da questão imigratória, o que não implicaria, segundo a autora, restrição do direito dos Estados em regular e controlar o ingresso, permanência, retorno e trânsito de pessoas pelas suas fronteiras, mas alteraria e minimizaria o enfrentamento e a restrição dos direitos sociais dos migrantes. A autora adverte, entretanto, que a escolha dos tratados multi ou 
bilaterais poderia polarizar a imigração, conduzindo a concertos em torno de práticas de interesse econômico dos Estados ricos em detrimento dos direitos dos migrantes. ${ }^{293}$

Em geral, a doutrina tende a concordar que a imigração deveria conviver com poucas barreiras colocadas pelos Estados e evidentemente muito menos imigração indesejada, assim entendida a imigração irregular, e muito mais gestão compartilhada entre os Estados.

Trata-se do que Reis define como políticas de dupla face, "voltadas para uma gestão conjunta da questão da migração, entre país receptor e emissor". ${ }^{294}$

Esse poderá ser um caminho positivo para o Brasil, que já firmou acordos dessa natureza. O Tratado Bilateral de Igualdade de Direitos, estabelecido em 1972, e o Tratado de Amizade, cooperação e consulta entre a República Federativa do Brasil e a República Portuguesa, em 2011.

Essa via, inclusive, poderia contribuir para a solução de conflitos entre países vizinhos, a exemplo do conflito denunciado em 2006 pela Comissão Parlamentar de Inquérito brasileira, criada para apurar os crimes e outros delitos penais e civis praticados com a emigração ilegal de brasileiros, envolvendo trabalhadores brasileiros em território paraguaio, na sua grande maioria trabalhadores rurais em território paraguaio em situação de risco em virtude de confrontos políticos no recente regime de Stroessner, além de acusações sobre danos ambientais em decorrência do uso do solo. ${ }^{295}$

Nessa mesma linha, Philip Martin é um dos defensores da remoção das barreiras aos migrantes, mediante a integração internacional entre os Estados, de modo a propiciar uma gestão conjunta dos migrantes entre os respectivos países de origem e os países de destino. ${ }^{296}$

293 Neide Lopes Patarra, Revista de Estudos Avançados, 20 (57), p. 20-23, 2006.

294 Rossana Rocha Reis, A política do Brasil para as migrações internacionais, p. 55, http://www.scielo.br/pdf/cint/v33n1/v33n1a03.pdf>.

295 Disponível em: 〈http://www.diasmarques.adv.brlartigos\Relatorio_CPI_Emigracao_ilegal.pdf〉. Acesso em: 5 out. 2013.

296 Philip Martin, Labor migration and development indicators in the post-2015 global development framework, p. 86-87. Disponível em: 〈http://migration.ucdavis.edulmn〉>. Acesso em: 13 set. 2013. 
A ideia não é nova e já havia sido discutida pelo Banco Mundial como uma forma positiva de abrir as portas dos países industrializados para um contingente de migrantes de baixa qualificação que desejam, de alguma forma, realizar o sonho de viver em uma economia mais estável e promissora do que a dura realidade que enfrentam em seus países de origem.

São milhões de trabalhadores de países em desenvolvimento que anseiam migrar para países industrializados, onde a remuneração de uma hora corresponde ao valor que receberiam em um dia ou até mesmo ao longo de uma semana inteira nos seus respectivos países de origem. ${ }^{297}$

O autor propõe a atuação conjunta dos Estados a partir da gestão de três impactos que afetam diretamente os migrantes e o desenvolvimento de seus países de origem e de destino: a) o recrutamento de trabalhadores; b) a remessa de dinheiro para os países de origem durante o período da migração; e c) o retorno ao país de origem.

Quanto ao recrutamento, a ideia de uma gestão integrada entre os Estados parte da constatação de que os padrões migratórios não ocorrem ao acaso, são fruto de redes de contato que se formam entre comunidade de indivíduos com interesses comuns. Interferir nesses padrões poderá ser virtuoso, se, ao retorno dos migrantes aos seus países de origem, passarem a contribuir para criar mais empregos, ou poderá ser desastroso para as nações receptoras, se o recrutamento direcionado acarretar um aumento significativo dos migrantes.

O segundo fator relevante para estabelecer uma atuação concertada dos países de origem e de destino consiste nas remessas de dinheiro enviadas pelos migrantes aos seus países de origem. De acordo com o relatório publicado em 2012, pelo Banco Mundial, as remessas enviadas por migrantes aos seus respectivos países somaram 406 bilhões de

297 Dados obtidos junto ao Banco Mundial, relatório "Migration and Development Brief 19”, 2012. Disponível em: <http://siteresources.worldbank.Org IINTROSPECTS\Resources \3349341288990760745\MigrationDevelopmentBrief19>. Acesso em: 2 abr. 2013. 
dólares em 2012, e as projeções indicam que poderão alcançar 534 bilhões de dólares até $2015 .^{298}$

A ideia, segundo Ratha, seria valorizar as remessas financeiras, propiciando taxas e câmbio e políticas econômicas que incentivem o crescimento das remessas. ${ }^{299}$

No que concerne ao retorno do migrante, Martin acrescenta que, apesar da dificuldade de assegurar que o retorno do migrante resultará em um círculo virtuoso entre imigração e desenvolvimento, entende o autor que os migrantes em geral compartilham mais do que remessas de dinheiro com o país de origem, e defende que o compartilhamento de ideias e informações que apreendem nos países de destino poderá ser útil para acelerar o desenvolvimento local. Levitt exemplifica que o migrante exposto a novas oportunidades poderá favorecer ao abandono de estereótipos locais, com ênfase para incremento do tempo de estudo, novos padrões de economia e maiores investimentos. ${ }^{300-301}$

\subsection{Ratificação da Convenção Internacional sobre os Direitos dos Trabalhadores Migrantes e Membros de suas Famílias}

A completa integração do migrante na sociedade exige reconhecer os direitos reconhecidos na Convenção da ONU, na forma que demonstramos no Capítulo 1. Em 2009, o Brasil assinou a Convenção, contudo, até a data de conclusão deste estudo, o País não a havia ratificado.

Em dezembro de 2010, enviou o pedido de ratificação ao Congresso Nacional e, em carta dirigida ao Presidente da República, o Ministro das Relações Exteriores Celso Amorim justifica a necessidade de fazê-lo, reforçando que a ratificação da Convenção daria maior legitimidade ao Brasil em seu papel em foros internacionais sobre direitos dos

298 Dados obtidos junto ao Banco Mundial, relatório “Migration and Development Brief 19”, 2012. Disponível em: <http://siteresources.worldbank.Org\INTROSPECTS $\backslash$ Resources \3349341288990760745\MigrationDevelopmentBrief19>. Acesso em: 2 abr. 2013.

299 D. Ratha, Worker's remmittances: an importante and stable source of external development finance, 2003. Relatório do Banco Mundial Global Development Finance, p. 152-150.

300 Philip Martin, Labor migration and development indicators in the post-2015 global development framework, p. 86-87. Disponível em: 〈http://migration.ucdavis.edulmn〉>. Acesso em: 13 set. 2013.

301 Peggy Levitt, Social remittances revisited, p. 23. Disponível em: <http://essays.ssrc.org। remittances_anthologylwp-contentluploads>. Acesso em: 2 ago. 2013. 
imigrantes, contribuindo para o processo de universalização da ratificação deste instrumento.

\subsection{Reforma da Lei n. 6.815/1980 e integração da Lei n. 7.064/1982}

A cooperação entre países é dificultada no Brasil pelos obstáculos jurídicos. Conforme exposto no Capítulo 3, as diretrizes da Lei n. 6.815/1980 decorrem de um regime militar que pregava a segurança nacional, e não mais se coadunam com a Carta Constitucional de 1988 tampouco refletem os avanços na construção dos direitos humanos dos trabalhadores migrantes.

Há um consenso na doutrina no sentido de que a atual lei de migração necessita de reforma em vários pontos a fim de fazer frente a um aumento incessante da mobilidade global, que abrangerá migrantes com diferentes graus de qualificação.

Nos vistos de trabalho, dois pontos requerem mudança urgente: a liberdade de mobilidade interna do migrante, de modo que lhe possa ser permitido aceitar outra proposta de emprego durante a migração, e a concessão de visto de trabalho automática ao cônjuge e dependentes do migrante.

Quanto ao direito de voto e o direito de concorrer a cargos políticos, é um anseio dos migrantes e inclusive está em curso campanha nacional a favor desse direito. Carta nesse sentido foi entregue aos Presidentes da Câmara dos Deputados e do Senado Federal e aos Chefes de Gabinete da Presidência da República em 2010.

Entretanto, o reconhecimento destes direitos requer a aprovação de Emenda à Constituição, posto que a Constituição restringe o direito de votar e ser votado aos brasileiros natos e aos estrangeiros naturalizados. ${ }^{302}$ Ao trabalhador migrante de baixa qualificação que adotar para si e para sua família uma estratégia de vida, que inclui a migração para o Brasil na tentativa de conquistar uma vida melhor, é preciso desenvolver mecanismos bilaterais de modo a alinhar fluxos de informação entre os países de origem, de modo que se crie uma rede de dados consistente que, alinhada a um conjunto de

302 Disponível em: <http://www.guiamigracoesdivcult.com|Imagenes_en_usolPDFs_da_guilGUIA_DAS_ MIGRACOES_completa.pdf>. Acesso em: 28 set. 2013. 
instituições com competência para integrar referidos dados às políticas públicas, torne possível a adoção de uma estratégia de ingresso e de permanência com respeito aos direitos humanos e erradicação da migração ilegal, que se afigura desastrosa para a vida do migrante e de seus familiares.

O trabalhador migrante altamente qualificado poderá aportar enorme contribuição tecnológica e científica para o desenvolvimento do País. O Brasil necessita incrementar as suas políticas migratórias com intuito de atrair esse potencial e paralelamente proteger o trabalhador nacional, inclusive quando este decide aceitar propostas para trabalhar no exterior.

Uma nova lei de migração poderia integrar a Lei n. 7.064/1982, que em sua essência preconiza a aplicação da lei mais benéfica ao trabalhador contratado ou transferido a partir do Brasil para o exterior, após uma revisão de seu conteúdo, ressaltando-se que a alteração promovida pela Lei n. 11.962/2009 não produziu nenhum efeito em termos de atualização no conteúdo da Lei de 1982, na medida em que apenas estendeu o âmbito de aplicação de suas disposições aos trabalhadores de todos os segmentos econômicos.

As relações jurídicas que hoje se estabelecem sob esta legislação submetem às partes a enorme insegurança jurídica. ${ }^{303}$

Sintetizando as questões controvertidas expostas no Capítulo 3 do presente estudo:

303 A Confederação Nacional das Indústrias (CNI) (Disponível em: <http://arquivos. portaldaindustria.com.brlapplconteudo_1812012120416014468777i.pdf>. Acesso em: 29 set. 2013) levantou em documento denominado 101 propostas para a modernização da legislação trabalhistas, questões como o tempo mínimo de permanência de um brasileiro no exterior para fins de caracterizar a chamada "expatriação", as dificuldades e o alto custo de benefícios sobrepostos para os processos de transferência provisória de trabalhadores brasileiros ao exterior foram pontuadas como alguns dos fatores de estagnação na qualificação e do intercâmbio de tecnologia e experiência que poderiam contribuir para o desenvolvimento profissional dos migrantes e para o desenvolvimento econômico do País, além de reduzirem oportunidades de trabalho para os migrantes brasileiros. Em relação ao ingresso de estrangeiros, a CNI ressaltou a insegurança jurídica causada pelas dúvidas em relação à lei de regência do contrato, que ainda remanescem após o cancelamento da Súmula n. 207 do TST, além de incidências de encargos trabalhistas, previdenciários e fiscais sobre benefícios, como aluguel e bens atribuídos ao migrante para o exercício da profissão, por exemplo, veículo e outros. 
a) reduzir o tempo de regularização profissional (acadêmica e legal) do profissional migrante, mediante estudo da compatibilidade de cursos de graduação nos países de maior fluxo de migração e adoção de tratados bilaterais que permitam o prévio reconhecimento de diplomas estrangeiros e prover melhor trânsito de documentação e informações necessárias à aprovação, pelos Conselhos profissionais, da autorização legal para o migrante exercer a profissão no País;

b) assegurar, sem restrições, os direitos trabalhistas ao migrante fronteiriço, com ou sem vínculo de emprego. Essa categoria de migrante tem seus direitos restritos em termos de região de trabalho, o que em nada contribui para um olhar positivo e humanístico à temática migratória;

c) revisar o tempo mínimo de permanência do migrante sob vínculo de emprego no exterior, a fim de enquadrá-lo nas disposições do Capítulo II da Lei n. 7.064/1982, sobretudo quando se trata de projetos de curta duração, em que o trabalhador permanece sem intuito de mudança de residência para o exterior e tem suas despesas custeadas pela empresa;

d) estabelecer os critérios para a definição da lei de regência do contrato de trabalho, levando em consideração a multiplicidade de fatores que atuam sobre os processos migratórios, sobretudo nas transferências intraempresas e que dão causa a significativos conflitos e insegurança jurídica para as partes contratantes;

e) definir limites e critérios claros para a incidência dos encargos trabalhistas sobre verbas pagas no exterior nos contratos sob vínculo de emprego, em especial o FGTS, durante e ao término do período de migração. As regras atuais estão desatualizadas e não contemplam dispositivos necessários para regular as situações sob as quais se desencadeiam os processos migratórios no século XXI. É necessário compreender que as relações migratórias envolvendo migrantes qualificados necessitam privilegiar a vontade das partes contratantes e que não raro esbarram em leis locais, sobretudo nas brasileiras, que em nada 
contribuem para a mobilidade desse contingente de trabalhadores, cujo conhecimento é fundamental para o desenvolvimento do País;

f) estabelecer critérios sobre benefícios e natureza jurídica à situação específica do migrante sob transferência intraempresas, inclusive revisar o conceito e abrangência do adicional de transferência que atualmente só é assegurado aos trabalhadores abrangidos pela Lei n. 7.064 - ainda assim sob regras de difícil compreensão sobre a utilidade deste adicional, que ao final deveria objetivar prover equilíbrio entre o custo de vida do país de origem e de destino, finalidade que já é alcançada com o custeio da moradia e outros benefícios proporcionados ao migrante transferido intraempresas;

g) discutir a viabilidade de "localização do contrato ao término da migração", de forma que as partes contratantes possam estabelecer critérios que disciplinem as situações nas quais a transferência que teve início como provisória, se transforme em permanente, sem a insegurança jurídica decorrente da proibição para adequar condições contratuais que se estabeleceram sob o caráter de provisoriedade, para uma realidade que surgir posteriormente e que envolve a permanência definitiva do migrante no país de destino. A Lei n. 7.064, conquanto trata apenas da situação do trabalhador local deslocado para prestar serviços no exterior, poderá inspirar a nova lei de migração, na medida em que dispõe sobre a supressão de benefícios cuja duração se pactuou para durar apenas durante a provisoriedade do contrato. É necessário que estas disposições também se apliquem expressamente à situação do estrangeiro destacado para prestar serviços no Brasil;

h) não é demais ressaltar a necessidade de esclarecer a incidência de benefícios e direitos trabalhistas previstos na legislação brasileira e sua incidência nos casos de transferência provisória e, especialmente, nas transferências definitivas;

i) quanto às contribuições previdenciárias, na vigência de acordos previdenciários bilaterais ou multilaterais, há que se estipular claramente 
se e quando haverá incidência da contribuição previdenciária patronal, particularmente nas hipóteses em que o trabalhador optar por contribuir para o regime de previdência social do país de origem.

\subsection{Acesso ao trabalho decente, com ou sem vínculo empregatício}

Em relação aos aspectos trabalhistas, o respeito ao trabalho decente se apresenta como primordial, convergindo para os quatro pilares da OIT: respeito aos direitos no trabalho, com ou sem vínculo empregatício, e em especial aqueles definidos na Declaração da OIT relativa aos Direitos e Princípios Fundamentais no Trabalho, adotada em 1998, ${ }^{304}$ e que incluem como fundamentais: a) a liberdade sindical e reconhecimento efetivo do direito de negociação coletiva, para os migrantes cuja relação jurídica se estabelecer sob vínculo empregatício; e aproximação dos Conselhos Profissionais e das entidades de apoio ao migrante para os migrantes cuja relação jurídica se estabelecer sob vínculos autônomos ou especiais (ex.: técnico estrangeiro, sob acordos de cooperação estabelecidos pelo governo brasileiro); b) eliminação de todas as formas de trabalho de trabalho forçado; c) abolição efetiva do trabalho infantil; d) eliminação de todas as formas de discriminação em matéria de emprego e ocupação; e) promoção do emprego produtivo e de qualidade, a extensão da proteção social e do fortalecimento do diálogo social.

Em especial, a limitação do acesso do migrante ao mercado de trabalho nacional requer uma revisão. Nosso anacrônico Estatuto do Estrangeiro impõe tamanha quantidade de restrições ao exercício profissional do migrante que revela a nítida intenção de tratar o ingresso e a permanência do migrante no País como uma circunstância excepcional e a ser combatida, restrita exclusivamente aos interesses do Estado e com a máxima proteção do trabalhador brasileiro, tal como se o migrante fosse um inimigo do cidadão brasileiro.

Nessa linha, as disposições do Estatuto do Estrangeiro confirmam que não estamos exagerando. Vejam-se, por exemplo, as disposições do art. 99, caput, do Estatuto, que, ao dispor sobre o migrante de país limítrofe, sob visto temporário, o proíbe de

304 Disponível em: 〈http://www.oitbrasil.org.br/defaut/files/topics/oit/doc/declaracao_oit_547.pdf〉. Acesso em: 9 out. 2013. 
estabelecer-se com firma individual ou exercer cargo ou função de administrador, gerente ou diretor de sociedade comercial ou civil, bem como inscrever-se em entidade fiscalizadora do exercício de atividade remunerada.

Ora, a partir da entrada em vigor do Acordo de Residência do Mercosul, em 2009, todos os cidadãos de países-membros, que inclui países limítrofes, têm direito de residirem no País. Não há, obviamente, sentido nenhum em residir sem poder exercer uma profissão que garanta a subsistência do migrante e de sua família. Mais que isso, diz o Acordo de Residência que, ao final de um período de dois anos, o cidadão abrangido pelo Acordo poderá pedir a sua residência permanente, se comprovar possuir meios de subsistência. Ora, se as regras não lhe permitem trabalhar, nem exercer legalmente uma profissão, está fadado a retornar muito antes de se completar o período de dois anos.

O Estatuto veda, ainda, ao trabalhador migrante uma série de profissões previstas nos dez itens do art. 106, em áreas que vão desde atividades jornalísticas (como proprietário ou responsável, orientador intelectual ou administrativo), corretor de navios, fundos públicos, leiloeiro e despachante aduaneiro, participar da administração ou representação de sindicato ou associação profissional, entre outras.

Ultrapassadas essas barreiras arcaicas, o migrante cujas qualificações se encaixarem em alguma atividade no Brasil, se submeterá a um complexo sistema, que tem início com o moroso e burocrático sistema de visto e de autorização de trabalho, e prossegue na obtenção dos documentos para obtenção da Carteira de Trabalho e Previdência Social.

O sistema de proteção dos trabalhadores migrantes remanesce dissociado da realidade. Falta, como ressalta Boaventura Santos, uma emancipação política de direitos humanos capaz de transformar o conceito e a prática dos direitos humanos, de um localismo globalizado, em um projeto cosmopolita insurgente. ${ }^{305}$

305 Boaventura Santos, A gramática do tempo para uma nova cultura política, p. 445. 


\subsection{Racionalidade e redução da burocracia e incremento de informações}

O sistema atual de gestão da política migratória necessita de modernização e simplificação de procedimentos. A atuação do CNIg é identificada como positiva, porém, diante do atual formato do sistema, esse órgão tem sua atuação restrita, pois não há a adequada integração com os demais órgãos, como apontamos no Capítulo 3. ${ }^{306}$

A criação de uma agência de migração poderia aprimorar significativamente os serviços de legalização do migrante, sobretudo se essa agência pudesse concentrar todos a emissão da autorização de trabalho e de todos os demais documentos requisitados para o pleno exercício de seus direitos políticos, civis e sociais.

Atualmente, os sistemas encontram-se isolados. O sistema político desempenha o papel de tomar decisões sobre a política migratória que afetará toda a comunidade, mas atua sozinho, assim como desempenham sozinhos e independentes os demais organismos. Aliás, essa tem sido uma tendência no País.

Como bem lembrado por Campilongo, a representação política, a economia e o direito operam em bases distintas e, embora possam ter relações entre si, isso não significa que um sistema poderá determinar o outro. ${ }^{307}$

Em outras palavras, autor exemplifica que os sistemas são isolados e atuam de forma autoestimulada e autocontrolada. O sistema político desempenha o papel de tomar decisões que afetam toda a comunidade e atua por um código binário que o autor denomina de: poder/não poder, inferior/superior, querer do detentor/não querer do submetido.

Enquanto isso, o sistema jurídico atua por outro código binário: legal/ilegal; lícito/ilícito; direito/não direito. O sistema jurídico, nesse embate, se vê obrigado, no papel de garantir direitos em conflito, a decidir com base nas premissas que são oferecidas pelo sistema político.

306 Esse tema foi mencionado no estudo da FGV intitulado Imigração como vetor estratégico do desenvolvimento socioeconômico e institucional do Brasil - Rio de Janeiro: FGV Projetos 2012. Disponível em: <http://fgv.br/sites/fgvprojetos.fgv.br/files/imigracoaao_911.baixa.pdf>. Acesso em: 8 out. 2013.

307 Celso Fernandes Campilongo, O direito na sociedade complexa, p. 77, 78, 147 e ss. 
Não é pouco o que está sob a responsabilidade do Poder Judiciário. O tema envolve princípios constitucionais extremamente importantes: direitos sociais (art. $6^{\circ}$ ), prestação de serviços públicos e competência do Poder Público para concessões e permissões (art. 175, parágrafo único), livre-iniciativa (art. 170).

E o embate envolve outras fontes de direito, a saber, o Estatuto do Estrangeiro, a Lei n. 7.064/1982, a CLT, e, finalmente, a jurisprudência do Tribunal Superior do Trabalho, que consolida o entendimento da Justiça sobre os limites em que as partes poderão livremente pactuar os respectivos contratos de trabalho internacional.

Nessa perspectiva, haveria de se propiciar que o migrante pudesse, durante o processo de ingresso, tratar das questões envolvendo revalidação de diplomas, se necessário, regularizar a sua situação perante o respectivo Conselho Profissional, iniciar procedimentos para a emissão do registro de identidade e da Carteira Profissional e conhecer sobre direitos e deveres na relação jurídico-trabalhista à qual se submeterá.

Ao imigrante sem qualificação, de baixa escolaridade, parece-nos imprescindível que possa contar como o apoio de agências voltadas a auxiliar na sua inserção no mercado de trabalho nacional. É que, diferente do migrante qualificado, esse contingente de trabalhadores não ingressa no Brasil por meio de convite de empresas locais, mesmo porque, ao contrário da realidade do Reino Unido e da França, a nossa política de migração não oferece essa possibilidade.

O migrante sem qualificação que atualmente ingressa no Brasil o faz mediante o benefício do Acordo de Residência do Mercosul, em vigor desde 2009, além de poucos acordos multilaterais firmados sobre o tema entre o Brasil e outros países, a exemplo do Equador.

Seria muito útil ao migrante sem qualificação se pudesse contar com o apoio do Serviço Nacional de Emprego (Sine), cuja estrutura é atualmente voltada exclusivamente ao emprego formal, sob vínculo empregatício.

Todavia, como vimos no Capítulo 1, o processo produtivo brasileiro, assim como no resto do mundo, incorporou outras maneiras de prestar serviço, exigindo a 
reformulação de instituições que, a exemplo de um Sine modernizado, poderiam incorporar a divulgação de oportunidades de empreendedorismo e parcerias objetivando oferecer informação e oportunidades de maior integração do migrante à nossa sociedade.

O Sine foi instituído pelo Decreto n. 76.403, de 08.10.1975, sendo inspirado na Convenção n. 88 da OIT, que trata da organização do Serviço Público de Emprego, ratificada pelo Brasil.

A principal finalidade do Sine, na época de sua criação, como divulgado pelo Ministério do Trabalho e Emprego, era promover a intermediação de mão de obra, implantando serviços e agências de colocação em todo o País (postos de atendimento). ${ }^{308}$

Além disso, previa o desenvolvimento de uma série de ações relacionadas a essa finalidade principal: organizar um sistema de informações sobre o mercado de trabalho, identificar o trabalhador por meio da Carteira de Trabalho e Previdência Social e fornecer subsídios ao sistema educacional e de formação de mão de obra para a elaboração de suas programações.

O Sine poderia ampliar a sua atuação para intermediar, com organizações da indústria, comércio e serviços, um conjunto de iniciativas, envolvendo parcerias entre empreendedores, trabalhos autônomos e domésticos, os quais seriam de grande ajuda aos migrantes.

\subsection{Participação dos corpos intermediários e da sociedade civil}

Não há como tratar da temática do trabalhador migrante sem promover a integração de todo os partícipes diretos desse fenômeno.

Afigura-se essencial abandonarmos a posição estática entre o interesse privado e o interesse público, e reconhecermos a importância da participação do que Marcondes denomina de "corpos intermediários", 309 na formação das políticas públicas e do direito

\footnotetext{
308 Disponível em: 〈http://www3.mte.gov.br/sine/oquee.asp>. Acesso em:13 out. 2013.

309 Roberto Rangel Marcondes, A importância da participação popular na definição do interesse público a ser tutelado pelo Ministério Público do Trabalho, p. 5.
} 
positivado que almejamos nesse tema, corpos esses integrados pela sociedade, corporações, empresas, associações, sindicatos, conselhos profissionais, organizações não governamentais e religiosas de apoio aos migrantes.

Falar de migração, segundo Sayad, "é falar da própria sociedade como um todo, falar dela em sua dimensão diacrônica, ou seja, numa perspectiva histórica (história demográfica e história política da formação da população)". ${ }^{310}$ Para o autor, o migrante existe sob o ponto de vista social, porque recebe essa denominação da sociedade, que se arvora no direito de não conhecer a vida que antecede esse momento. $\mathrm{O}$ etnocentrismo, diz o autor, implica "só se conhecer o que se tem interesse em conhecer". 311

Essa reflexão nos parece de suma importância para lançar luzes à migração no Brasil, ou seja, é necessário divulgar o tema à sociedade e chamá-la a participar.

A posição é confirmada pela Irmã Rosita Milese, expoente batalhadora pela garantia e expansão dos direitos dos migrantes, que, em entrevista concedida a Coentro, destacou que

[...] o Conselho (CNIg) permite a construção de posições coletivas por intermédio de um debate democrático em que todos aqueles que têm relação com a temática podem se envolver e, na prática, efetivamente o fazem. Não obstante, o status de sua participação (Milesi), como observadora (assim como de outros membros), não lhe confere a prerrogativa de voto nas reuniões do Conselho. E isto se coloca como uma questão a se discutir quando da estruturação do futuro Conselho Nacional de Migrações [...]. . $^{312}$

De outro norte, um exemplo a ser evitado é a exclusão da participação dos corpos intermediários, como ocorreu com os Conselhos profissionais, na situação envolvendo o convênio "Mais Médicos", em que a indisposição entre o governo e o Conselho Federal de Medicina, não obstante outros aspectos controvertidos dessa cooperação internacional, acarretou enormes dificuldades para os profissionais cambistas

\footnotetext{
310 Abdelmalek Sayad, A imigração: ou os paradoxos da alteridade, p. 16.

311 Abdelmalek Sayad, A imigração: ou os paradoxos da alteridade, p. 16.

312 Luciana Unis Coentro, Políticas públicas e gestão das migrações internacionais do Brasil: uma reflexão sobre os migrantes qualificados, p. 133.
} 
e, ao final, prejudicou a população que poderia ser beneficiada com o apoio desses profissionais.

Por outro lado, um exemplo positivo denota-se no segmento dos profissionais de engenharia, em que o Conselho atuou de forma a instituir a parceria entre profissionais estrangeiros e brasileiros, como um requisito a ser observado pelas empresas contratantes com o objetivo de intercâmbio de experiências, produzindo efeitos positivos para todos.

\subsection{Respeito aos direitos humanos mediante diálogo e consenso}

\section{- Organizações sindicais ou redes internacionais}

A atuação do movimento sindical na defesa dos direitos dos migrantes é um fenômeno relativamente novo e ainda muito fragmentado. Ocorre que muitos sindicatos, sobretudo no Brasil, compartilham da opinião de que os trabalhadores migrantes representam um risco aos empregados locais e esses, em última instância, se constituem no campo de atuação da organização sindical e a sua principal fonte de custeio.

Ademais, a organização sindical é uma questão interna, restrita à competência nacional de cada país. Não é por outra razão que Mascaro destaca a regulação desse tema em uma dimensão comunitária não é desejada pelos blocos econômicos, que reservaram um canal de diálogo restrito entre os trabalhadores empregados em empresas transnacionais, na forma do que dispõe a Diretiva n. 94/95/CE, que obriga as empresas transnacionais "assim consideradas as que se instalaram em mais de um país do território europeu comunitário". 313

O autor destaca que o Acordo sobre Política Social, do Tratado da União Europeia, em seu art. $2^{\circ}, 6$, tratou de excluir a competência normativa comunitária quanto ao direito de associação, o direito de greve e o locaute, remanescendo apenas o direito de negociação coletiva, entre partes sociais no nível comunitário, o que cedeu espaço à preservação de entidades que existiam antes da UE, a exemplo da Organização Regional da Confederação Internacional do Sindicatos Livres - ORE-CISL, de 1950, e da União das

\footnotetext{
313 Amauri Mascaro Nascimento. Compêndio de Direito Sindical, p. 139.
} 
Indústrias da Comunidade Europeia - UNICE, de 1958. Houve também a criação de novas entidades, a exemplo da Confederação Mundial do Trabalho (CMT), de 1974.

Nessa perspectiva, a atuação conjunta do movimento sindical internacional é identificada como um mecanismo precário, voltado muito mais à proteção do conjunto de empregados de determinada empresa transacional, residentes nas respectivas localidades nas quais a empresa possui suas filiais, do que propriamente à defesa dos direitos trabalhistas do migrante.

No âmbito do Mercosul, Cássio Mesquita Barros Júnior identifica pequeno avanço, ainda incomparável e distante do que foi alcançado pela União Europeia, mas que, no entanto, propiciou a formação de organizações voltadas à representação de setores econômicos e sociais específicos. A Organização Regional Interamericana dos Trabalhadores - ORIT, de 1986, propiciou, no mesmo ano, a criação da Coordenadoria de Centrais Sindicais do Cone Sul - CCSCS, com o intuito de sintonizar as organizações sindicais em escala regional sul-americana. ${ }^{314}$

No Brasil, merece destaque as redes internacionais sindicais criadas com o propósito de organizar os trabalhadores de uma mesma categoria em cada fábrica da mesma empresa, independentemente da localização geográfica. De acordo com Gomes, a Confederação Nacional dos Metalúrgicos (CNM-CUT), foi pioneira ao criar, em 1999, o comitê da Volkswagen, que propiciou a participação dos representantes dos trabalhadores da montadora nas reuniões mundiais, unificando a luta por melhores condições de trabalho em todos os países onde a empresa atua. ${ }^{315}$

Os desafios que se colocam exigem cooperação de todos os órgãos e os atores sociais, em verdadeira revisão dos papéis na busca de maior entrosamento.

\section{- As empresas multinacionais}

As empresas multinacionais, por sua vez, também assumem um importante papel na liderança desse processo, como inclusive já reconheceu a Organização para

\footnotetext{
${ }^{314}$ Cássio Mesquita Barros Júnior. Perspectivas do direito do trabalho no Mercosul, p. 156.

${ }^{315}$ Maíra Neiva Gomes. Redes internacionais sindicais, p. 3 disponível em http://www.ambitojuridico.com.br/site/index.php?n_link=revista artigos leitura\&art . Acesso em: 28 set. 2013.
} 
Cooperação e Desenvolvimento Econômico (OCDE), ao aprovar as diretrizes para as empresas multinacionais.

Alle lembra que a OCDE, criada em 1960, da qual o Brasil não é membro, mas mantém relações importantes de cooperação, na exata linha de atuação preconizada pelo art. 4. ${ }^{\circ}$ da Constituição Federal de 1988, que dispõe sobre o princípio "da cooperação entre os povos para o progresso da humanidade".

O conteúdo das diretrizes enuncia a necessidade de fomentar a contribuição positiva que as empresas multinacionais podem trazer para o progresso econômico, social e ambiental, e minimizar e resolver as dificuldades que possam surgir em decorrência das atividades dessas empresas.

Em 2011, foi inserido nessas diretrizes um tópico que objetiva impor o compromisso de, no contexto de suas atividades, as empresas multinacionais evitarem causar ou contribuir para impactos adversos aos direitos humanos e gerenciarem esses impactos, quando operarem em relação a emprego e relações industriais, respeito às negociações, consultas e diálogos, incluindo cuidados nas relações com sindicatos, em atenção à transparência nas informações, além da abolição do trabalho infantil, trabalho forçado e discriminação entre trabalhadores.

Sob outro ângulo, as empresas, a nosso ver, devem incrementar a prática mais difundida entre as empresas multinacionais, que são os Códigos de Conduta, mediante os quais se autoimpõem a estabelecer princípios globais trabalhistas que se aplicam a todos os indivíduos empregados por quaisquer empresas do mesmo grupo econômico. O Código passa a ser importante inclusive para estabelecer atividades que contribuirão para auditorias sociais em fornecedores para coibir a lesão a direitos de forma geral, inclusive para investigar a ocorrência de utilização de mão de obra de migrantes em condições irregulares, e a imposição aos integrantes da cadeia produtiva, da comprovação do registro correto e da regularidade de permanência dos estrangeiros, de modo que possam usufruir 
de jornada de trabalho legal, além de garantia de condições de meio ambiente de trabalho, segurança e saúde, bem como do combate à servidão por dívidas. ${ }^{316}$

316 Nesse particular, ver o TAC avençado entre Lojas Zara e o Ministério Público do Trabalho, disponível em: <http://reporterbrasil.org.br/agenciadenoticicas/tacZara.pdf>. Acesso em: 27 set. 2013. 


\section{CONSIDERAÇÕES FINAIS}

A presente tese objetivou demonstrar as forças que atuam sobre as políticas migratórias atuais, como uma forma de lançar luzes sobre o tema, no momento em que se discute uma nova lei migratória, que entra em vigor nos Estados Unidos, cujo tema ganha corpo no Brasil, que também discute uma nova lei migratória.

Os modelos estudados revelam a preponderância de políticas migratórias modeladas segundo interesses econômicos, privilegiando o ingresso do migrante qualificado em detrimento do migrante sem qualificação e de baixa escolaridade.

Ideias fixas que tratam a mobilidade de pessoas como um problema a ser contido, em vez de um tema a ser discutido em compasso com as garantias dos direitos humanos, suportam enormes restrições à migração a trabalho.

O Brasil vive um momento extremamente oportuno para reposicionar a nova política migratória brasileira. Os anos seguintes serão fundamentais para a política migratória, sobretudo com a Copa do Mundo e a crise econômica que assola a Europa. O Brasil tem a oportunidade de dar exemplo de respeito aos direitos humanos.

\section{O que vai acontecer com a política migratória brasileira?}

No início desta tese, comprometemo-nos a direcionar os estudos de modo a encontrar resposta para as duas questões fundamentais à política migratória.

$\mathrm{Na}$ sequência de nossas considerações, ensaiamos nossas respostas, sem nenhuma intenção de consagrar verdades ou encerrar o assunto, haja vista que o tema é por demais complexo e está em constante mutação, de modo que nosso exercício de pesquisa nada mais representa senão a "foto do momento", na temática migratória. Com essa fotografia em mãos, propomos as seguintes respostas: 


\section{A definição dos direitos dos migrantes internacionais a trabalho sofre influências decorrentes do conceito contemporâneo de cidadania?}

Sim, sem dúvida alguma, a cidadania atua fortemente na definição dos direitos dos migrantes. O estudo dos países selecionados nesta tese comprova as restrições impostas aos migrantes por força da cidadania.

Com efeito, na União Europeia, que ainda figura como única entidade que efetivamente recebeu a transferência da soberania de seus Estados-membros, que se aplicam mediante a existência das Diretivas à livre circulação de trabalhadores, e outros direitos, as Diretivas impactam diretamente na vida dos migrantes.

$\mathrm{Na}$ verdade, há muito o que aprimorar, inclusive para a mobilidade dos europeus, o que dirá em relação a nacionais de países terceiros. A Diretiva de Retorno, 2008/115, aprovada pelo Parlamento europeu, com a finalidade de promover o regresso de migrantes irregulares, figura como um péssimo exemplo à evolução dos direitos dos migrantes e um divisor de águas entre os migrantes regulares e irregulares.

Os primeiros desfrutam de razoável proteção nos países desenvolvidos, a qual tanto será maior quanto mais elevada a qualificação do migrante, enquanto os segundos sofrem reconhecida exclusão e risco de deportação.

Não é diferente no âmbito dos países do Nafta. As regras migratórias adotadas pelo Nafta confirmam a tendência de proteção a migrantes regulares, qualificados, e apontam para a discriminação baseada na nacionalidade. Esse aspecto se denota claramente nas políticas migratórias dos Estados Unidos, que tradicionalmente inibem o ingresso de cidadãos do México e de países em desenvolvimento, enquanto incentivam a vinda de profissionais qualificados, aos quais conferem razoável nível de proteção contra a discriminação e promovem medidas voltadas a contribuir com a inserção do migrante na economia local.

No Mercosul, as normas de mobilidade internacional são bem mais recentes. Somente a partir de 2009 é que entrou em vigor o Acordo de Residência do Mercosul, que permite a estadia de nacionais dos países-membros por um período provisório de dois anos. 
As políticas migratórias dos países estudados favorecem o ingresso regular de migrantes qualificados e nesse aspecto não garantem a ampla igualdade de direitos entre nacionais e estrangeiros. França, Reino Unido e Alemanha possuem programas voltados à migração de pessoas sem qualificação, mas limitam o exercício de funções em atividades identificadas em listas oficiais, as quais contemplam atividades não preenchidas com os recursos humanos nacionais.

Os Estados Unidos divulgam claramente o propósito de abrir suas fronteiras aos migrantes qualificados, em detrimento de migrantes sem qualificação, para os quais as políticas migratórias estão voltadas a inibir ao máximo o ingresso no país.

No âmbito do Mercosul, a política migratória é igualmente voltada para o migrante qualificado e o seu ingresso e estadia são sempre vinculados a uma única empresa e região, não há liberdade de escolher o trabalho ou a empresa em que se vai trabalhar, muito menos a região. Ao trabalhador sem qualificação o ingresso que permite maior mobilidade interna no território nacional se dá mediante o Acordo de Residência do Mercosul, uma vez que não se exige comprovar que o ingresso está vinculado ao convite formulado por empresa local. Todavia, o processo de integração do migrante (qualificado e sem qualificação) é confuso, moroso e complexo.

\section{O status do migrante (sem qualificação ou qualificado) influencia de alguma maneira a formulação das atuais políticas públicas migratórias? Experiências internacionais nesse tema podem inspirar a nova política migratória brasileira, à vista da igualdade e da ética?}

De maneira geral, os países estudados adotam duas formas básicas de autorização de ingresso em território nacional para outros fins que não o de turismo: visto de negócios e visto de trabalho (com ou sem vínculo de emprego).

O visto de negócios objetiva basicamente o ingresso e a permanência do estrangeiro por curtos períodos de tempo, em geral três a seis meses, para atendimento de reuniões de negócios, treinamentos, com restrição ao pagamento de tais atividades mediante fonte local. 
O visto de trabalho normalmente admite a execução de atividades remuneradas, porém normalmente restritas aos migrantes qualificados.

Praticamente não existem políticas voltadas a regular o ingresso de migrantes sem qualificação, salvo exceções, dentre as quais destacamos a França, a Alemanha e o Reino Unido, onde a mão de obra não qualificada é admitida, mas apenas para a execução de determinadas tarefas em segmentos econômicos nos quais as vagas não são do interesse dos trabalhadores nacionais.

Nesse sentido, é forçoso concluir que as restrições ao ingresso de migrantes assumem implicações sérias perante os direitos humanos. Assim, é mais do que urgente repensar os aspectos da migração contemporânea, estabelecendo parcerias internacionais para estabelecer controle adequado dos fluxos, propiciando maior liberalização de ingresso e permanência dos trabalhadores migrantes e suas famílias.

Assim, em grande medida, o caminho para o alinhamento do tema migratório no Brasil passa necessariamente pelos acordos bilaterais e por uma reforma ampla de instituições e mecanismos que atuam sobre esse tema, mediante a consciência de que o fluxo de pessoas só tende a aumentar pela atuação das forças da globalização, tornando necessário repensar nossa política migratória de modo que o País possa realmente tirar proveito dos migrantes qualificados para o desenvolvimento da economia e ao mesmo tempo tratar da temática do migrante sem qualificação mediante a integração, em vez da exclusão.

O princípio da igualdade aplica-se na exata medida da Convenção Internacional de Proteção ao Trabalhador Migrante e aos membros de sua família. Haverá certas limitações atreladas ao tempo de permanência, da forma admitida na própria convenção, a exemplo do pleno acesso aos benefícios da Previdência Privada, mas há um limite de até dois anos de permanência no país para que sejam igualados aos nacionais. 


\section{REFERÊNCIAS}

ABDALA, Vitor. Lula diz que Brasil está aberto aos imigrantes. A Tarde, maio 2010. Disponível em: <http://www.atarde.com.brlpoliticalnoticia.jsf?id=2535914>. Acesso em: 28 maio 2010.

A BÍBLIA SAGRADA. Tradução de João Ferreira de Almeida. 2. ed. rev. e atual. no Brasil. São Paulo: Sociedade Bíblica do Brasil, 1993.

ACCIOLY, Tatiana de Almeida. A circulação internacional de mão de obra qualificada na atualidade: políticas imigratórias dos Estados Unidos e Canadá e o escritório de imigração do Quebec em São Paulo. 2009. Dissertação (Mestrado) - Universidade do Rio de Janeiro (UERJ), Rio de Janeiro:

Mobilidade da mão de obra qualificada no mundo atual: discutindo os conceitos de brain drain, brain gain, brain waste e skill exchange. VI Encontro Anual de Migrações - ABEP. Disponível em: <http://www.abep.nepo.unicamp.br $>$ docslanaisloutros $\mid 6$ EncNacSobreMigrações\ST3\Tatiana AlmeidaAccioly.pdf $>$. Acesso em: 8 out. 2013.

ALBUQUERQUE, Rui de; ALBUQUERQUE, Martim de. História do direito português. Lisboa: FDL, 1983. v. 1, t. II.

AMARAL JÚNIOR, Alberto do. Introdução ao direito internacional público. São Paulo: Atlas, 2008.

ARAUJO, Nadia de. Direito internacional privado: teoria e prática brasileira. 4. ed. atual. e ampl. Rio de Janeiro: Renovar, 2008.

ARAUJO, Orlando de. $O$ trabalhador global e a previdência: reflexões sobre um direito humano em crise. Rio de Janeiro: Lumen Juris, 2013.

ARENDT, Hannah. As origens do totalitarismo. Tradução de Roberto Raposo. Rio de Janeiro: Relume-Dumará, 1979.

_. Los orígenes del totalitalismo. Madrid: Taurus, 1974. 
ARIOSI, Mariângela. Globalização das relações de trabalho e seus reflexos no cenário brasileiro: uma breve análise do conselho nacional de imigração. Revista Forense, Rio de Janeiro, n. 358, p. 115-132, 2001.

BAENINGER, Rosana. Migrações internacionais recentes: o caso do Brasil. In: PELlEGRINO, A. (Org.). Migración e integración. Montevidéo: Ediciones Trilce, 1995. p. 70.

Populações e políticas sociais no Brasil: os desafios da transição demográfica e das migrações internacionais. Brasília: Centro de Gestão e Estudos Estratégicos, 2008.

BALLARINO, Tito. Cidadania e nacionalidade: efeitos e perspectivas nacionais regionais - globais. Organização de Arno Dal Ri Júnior e Odete Maria de Oliveira. 2. ed. Ijuí: Ed. Unijuí, 2003.

BANDEIRA DE MELLO, Celso Antônio. Curso de direito administrativo. 13. ed. São Paulo: Malheiros, 2001.

BAPTISTA, Luiz Olavo. Aplicação do direito estrangeiro pelo juiz nacional. Aplicação da lei estrangeira designada pela regra de conflito. Obstáculos à aplicação do direito estrangeiro. Revista dos Tribunais, São Paulo, v. 88, n. 764, p. 33-45, 1999.

As instituições do Mercosul: comparações e prospectiva. In: FREITAS, Deyse de (Coord.). O Mercosul em movimento. Porto Alegre: Livraria do Advogado, 1995. p. 58-59.

—. O direito estrangeiro nos tribunais brasileiros. Aplicação da lei estrangeira designada pela regra de conflito. Obstáculo à aplicação do direito estrangeiro. As execuções implícitas na legislação. As exceções explícitas na legislação. Revista Forense, Rio de Janeiro, v. 97, n. 355, p. 89-99, 2001.

BARBAS, Leandro Moreira Valente. Imigração de gestores de empresas transnacionais, expatriação, proteção à mão de obra nacional e desenvolvimento. Monografia. 2010, p. 18. Disponível em: <http://bibliotecadigital.fgv.br/dspace/biststream/ handle/10438/migra\%c3\%7\%gestores\%20transnacionais\%20\%brasil.pdf>. Acesso em: 2 out. 2013. 
BARROS JÚNIOR, Cássio de Mesquita. Cômputo de tempo de serviço prestado no estrangeiro por força de acordo internacional. In: MARTINEZ, Wladimir Novaes (Coord.). Temas atuais de previdência social: homenagem a Celso Barroso Leite. São Paulo: LTr, 1998. p. 78.

(Org.). Global Mobility Handbook 2010. Vários colaboradores. São Paulo: Saraiva, 2010.

—. Perspectivas do direito do trabalho no Mercosul. São Paulo: LTr, 2011.

—. Transferência de empregados urbanos e rurais. São Paulo: LTr, 1980.

BARROS FILHO, Clóvis de; POMPEU, Júlio. A filosofia explica as grandes questões da humanidade. Rio de Janeiro: Casa da Palavra; São Paulo: Casa do Saber, 2013.

BASSO, Maristela. O Brasil pratica ato ilegal e imoral contra os haitianos. Disponível em: <www.migalhas.com.br>. Matéria colocada no ar originalmente em 18.01.2012. Acesso em: 2 mar. 2013.

BASTOS, Celso Ribeiro. Curso de direito constitucional. 16. ed. São Paulo: Saraiva, 1994.

BECKER, Gary S. Human capital: a theoretical and empirical analysis, with special reference to education. 2. ed. London: NBER, 1975.

BEDIN, Gilmar Antonio. Cidadania e nacionalidade: efeitos e perspectivas nacionais regionais - globais. Organização de Arno Dal Ri Júnior e Odete Maria de Oliveira. 2. ed. Ijuí: Ed. Unijuí, 2003.

BLAIPAIN, Roger et al. The global workplace: international and comparative employment law - cases and materials. Cambridge: Cambridge University Press, 2009.

—. Cambridge: Cambridge University Press, 2007.

BELTRAN, Ari Possidonio. A globalização e seus impactos nas relações de trabalho. Trabalho e Ambiente, v. 5, p. 9-41, 2007. 
BOBBIO, Norberto. A era dos direitos. Tradução de Carlos Nelson Coutinho. Apresentação de Celso Lafer. Nova edição. 8. ${ }^{a}$ reimpressão. Rio de Janeiro: Elsevier, 2004.

- Teoria geral da política: a filosofia e as lições dos clássicos. Organização de Michelangelo Bovero. Tradução de Daniela Beccaccia Versiani. Rio de Janeiro: Campus, 2000.

BODIN, Jean. Le xis livres de La République: Paris: A Lyon Libraire iure em L'uniuerfité, LXXIX. Disponível em: <https://play.google.com/books/reader? id=T3VMAAAAcAAJ\&printsec=frontcover\&output=reader\&authuser=0\&hl=pt_B R>. Acesso em: 11 maio 2013.

BOUCINHAS FILHO, Jorge Cavalcanti; BARBAS, Leandro Moreira Valente. Migração de trabalhadores para o Brasil. São Paulo: Saraiva, 2013.

BRIMELOW, Russel. Global Mobility Handbook 2010. Vários colaboradores. Organização de Cassio Mesquita Barros. São Paulo: Saraiva, 2010.

BRUGGER, Wilfried. Liberalismus, Pluralismus, Kommunitarismus. Baden-Baden: Nomos, 1999.

BYTSENKO, Anastassia. Imigração da Rússia para o Brasil no início do século XX. Visões do paraíso e do inferno. 2006. Dissertação de Mestrado. Faculdade de Filosofia, Letras e Ciências Humanas (FFLCH), São Paulo.

CACCIAMALI, Maria Cristina. As políticas ativas de mercado de trabalho no Mercosul. Estudos Avançados, São Paulo, v. 19, n. 55, set. 2005. Disponível em: <http://dx.doi.org/10.1590/SO103-4014200500030007>. Acesso em: 5 jul. 2013.

CAHALI, Yussef Said. Estatuto do Estrangeiro. 2. ed. rev., atual. e ampl. São Paulo: RT, 2010.

CALVO, Adriana. Diretor de sociedade anônima: patrão - empregado? São Paulo: LTr, 2006.

CAMPILONGO, Celso Fernandes. O direito na sociedade complexa. 2. ed. São Paulo: Saraiva, 2011. 
CAMPOS, Marden Barbosa. Reversão do saldo migratório internacional negativo do Brasil? Evidências preliminares com base nos dados do censo 2010. Revista Paranaense de Desenvolvimento, Paraná, v. 121, p. 185, 2012.

CANÇADO TRINDADE, Augusto Antonio. Tratado de direito internacional dos direitos humanos. Porto Alegre: Fabris, 1997. v. 1.

CANOTILHO, J.J. Gomes. Enquadramento jurídico da imigração, p. 153. Disponível em: $<$ http://www.museuemigrantes.org/docs/conhecimento/actas_Icongresso\%20em\%portugal.pdf >. Acesso em: 28 set. 2013.

CARDONA, Angela Maria Alves. Breves considerações sobre a situação migratória de estrangeiros bolivianos no Brasil. Porto Alegre, Justiça do Trabalho, v. 23, n. 274, p. 20-33, 2006.

CARENS, Joseph H. The ethics of immigration. Oxford: Oxford University Press, 2013.

CARRION, Valentim. Comentários à CLT. 32. ed. atual. por Eduardo Carrion. São Paulo: Saraiva, 2007.

CARVALHAIS, Isabel Estrada. A União Europeia e o outro - tensões e compromissos da lógica subjacente à sua gestão da imigração de países terceiros. Disponível em: $<$ http://www.ces.uc.pt/ecadernos/media/ecadernos10/7\%\%20Isabe1\%20Estrada\%20Carvalhais.pdf $>$. Acesso em: 27 set. 2013.

CARVALHO, José Alberto M. Migrações internacionais do Brasil nas duas últimas décadas do século 20: algumas facetas de um processo complexo, amplamente desconhecido, Texto apresentado no Encontro sobre Remessas, Previdência Social e Políticas Públicas, Brasília, 2004.

CASSAR, Vólia Bomfim. Aplicação do direito do trabalho no território, no tempo e no espaço. $L T r$, v. 69, n. 10, p. 1178-1179, out. 2005.

CASTLES, S.; MILLER, M. J. The age of migration: international population movements in the modern world. London: Macmillan Press, 2011. 
CASTRO, Carlos Alberto Pereira de; LAZZARI, João Batista. Manual de direito previdenciário. 14. ed. Florianópolis: Conceito Editorial, 2012.

CAVARZERE, Thelma Thais. Direito internacional da pessoa humana: a circulação internacional de pessoas. Rio de Janeiro: Renovar, 2001.

CHIQUIAR-RABINOVICH, Salomon. Esq. The American continente region. In: BARROS, Cássio Mesquita (Org.). Global Mobility Handbook 2010. São Paulo: Saraiva, 2010. p. 15-16.

CHOLEWINSKI, Ryszard; PERRUCHOUD, Richard; MACDONALD, Euan (Ed.). International migration law: developing paradigmas and key challenges. Hage: T.M.C. Asser Press, 2007.

CHOTHANI, Poorvi (Ed.). Global mobility. An overview for Human Resource Professionals. Vários colaboradores. Mumbai: Ed. Law Quest, 2012.

COENTRO, Luciana Unis. Políticas públicas e gestão das migrações internacionais do Brasil: uma reflexão sobre os migrantes qualificados. 2011. Dissertação (Mestrado) - Escola de Administração de Empresas de São Paulo, São Paulo.

COGO, Denise Maria; SOUZA, Maria Badet. Guia das migrações transnacionais e diversidade cultural para comunicadores - migrantes no Brasil. Instituto Humanitas, Unisinos. Disponível em: <http://www.guiamigracoesdivcult.com>. Acesso em: 29 set. 2013 .

COMPARATO, Fábio Konder. A civilização capitalista: para compreender o mundo em que vivemos. São Paulo: Saraiva, 2013.

CORREIA, Marcus Orione Gonçalves. Por uma metodologia dos direitos humanos uma análise na perspectiva dos direitos humanos. Revista do Departamento de Direito do Trabalho e da Seguridade Social, v. 4, p. 118-174, 2007.

—. Uma análise comparativa entre o sistema de seguridade social brasileiro e o japonês - em busca de soluções para os trabalhadores brasileiros residentes no Japão. Revista de Previdência Social, São Paulo, n. 258, p. 367-372, 2002. 
CRIVELLI, Ericson. Direito internacional do trabalho contemporâneo. São Paulo: LTr, 2010.

CUTTER. The global executive individual tax, social security and immigration $R(047)$, 2009. Disponível em: <http://tmagazine.ey.com/insights/the-2009-global-executiveindividual-tax-social-security-and-immigration/>. Acesso em: $22 \mathrm{dez} .2013$.

DALLEGRAVE NETO, José Affonso. Conflito de leis trabalhistas no espaço. Elemento de conexão. As normas de ordem pública. A previsão da Lei n. 7.064/82 e a teoria da irradiação. Os direitos especialmente previstos na Lei n. 7.064/82. A primazia da lei do pavilhão para os marítimos e aeronautas. O alcance do DL n. 691/69. O tema sob a ótica neoliberal. Sintese Trabalhista, Porto Alegre, v. 11, n. 130, p. 47-57, 2000.

DAL RI JUNIOR, Arno. Cidadania e nacionalidade: efeito e perspectivas: nacionais regionais - globais. Organização de Arno Dal Ri Júnior e Odete Maria de Oliveira. 2. Ed. Ijuí: Ed. Unijuí, 2003.

DELGADO, Mauricio Godinho. Curso de direito do trabalho. 2. ed. São Paulo: LTr, 2003. - Regência normativa da remoção de empregados brasileiros para o exterior. Transferência obreira para o Brasil: regência normativa. Transferência obreira para o exterior: regência normativa. Transferência para o exterior: diploma normativo especial, Lei 7.064/82. Aplicação analógica da Lei 7.064/82: possibilidades e limites. Síntese Trabalhista, Porto Alegre, v. 13, n. 147, p. 11-17, 2001.

DE PLÁCIDO E SILVA. Vocabulário jurídico. Rio de Janeiro: Forense, 1999.

DINIZ, Maria Helena. Curso de direito civil brasileiro: direito de empresa. São Paulo: Saraiva, 2008. v. 8.

FELICIANO, Guilherme Guimarães. Dos princípios do direito do trabalho no mundo contemporâneo. Revista Nacional de Direito do Trabalho, v. 107, p. 15-33, 2007.

FERRY, Jean Marc. La Question de l'État Européen. Paris: Gallimard, 2000.

FREITAS, Antonio de Jesus da Rocha. Manual do Mercosul: globalização e integração regional. São Paulo: BH Editora, 2006. 
FREITAS JR., Antonio Rodrigues de. Tráfico de pessoas e repressão ao crime organizado. Revista Internacional de Direito e Cidadania, v. 2, p. 9-14, 2009.

—. Direitos humanos, segurança pública e tráfico de seres humanos: repressão e responsabilização. Notas para uma reflexão e debate. Revista de Direito e Política, v. XIII, p. 15-19, 2007.

; MERINO, Lucyla Tellez. Horizontes para o direito numa sociedade em mudança: dilemas da Alca, impasses do Mercosul e crise do Estado: nação como círculo retroalimentador. São Paulo: LTr, 2004.

—; PANNUNZIO, Eduardo; UNGARO, Gustavo (Org.). Tráfico de pessoas e direitos humanos. São Paulo: BH Editora, 2006.

GAUDEMET, Jean. Eglise et societé en occident au moyen age. Variorum Reprint, 1984.

GARCIA, Maria. O processo constitucional no direito estrangeiro: o direito de resistência e a desobediência civil. A constituição como processo. $\mathrm{O}$ direito de resistência e as constituições portuguesa e alemã. A desobediência civil. O cidadão, a desobediência civil e a arguição de inconstitucionalidade. A instrumentalização da desobediência civil. Revista de Direito Constitucional e Internacional, São Paulo p. 56-61. v. 14. n. 57, 2006.

GIALIAN, Eliana. Expatriação e gênero: um referencial para multinacionais brasileiras. 2009. Dissertação (Mestrado) - Faculdade de Economia, Administração e Contabilidade (FEA), São Paulo.

GIDDENS, Anthony. As consequências da modernidade. Tradução de Raul Fiker. São Paulo: Unesp, 1991.

GOMES, Maíra Neiva. Redes internacionais sindicais. Disponível em http://www.ambitojuridico.com.br/site/index.php?n_link=revista_artigos_leitura\&art. Acesso em: 28 set. 2013.

GRADILONE, Eduardo. Proposta de política governamental para comunidades brasileiras no exterior, brasileiros no mundo. I. Rio de Janeiro, Anais eletrônicos..., Brasília: Ministério das Relações Exteriores, Subscretaria-Geral das Comunidades brasileiras 
no exterior, 2008. Disponível em: <http://www.abe.mre.gov.br>. Acesso em: 18 out. 2010.

GUINOT, Pascal. Global Mobility Handbook 2010. Organização de Cássio Mesquita Barros. São Paulo: Saraiva, 2010.

HOBSBAWN, Eric. Globalização, democracia e terrorismo. São Paulo: Companhia das Letras, 2007.

HOUAISS Antônio; VILLAR, Mauro Salles. Dicionário Houaiss da língua portuguesa. Rio de Janeiro: Objetiva, 2001.

HUME S.; NIESE, J. Ratifying the UM Migrant Workers Convention: Current Difficulties and Prospects. Netherlands Quarterly of Human Rights, 1994.

HUSEK, Carlos Roberto. Curso básico de direito internacional público e privado do trabalho. 2. Ed. São Paulo: LTr, 2011.

JANNUZZI, Paulo de Martino. Migração e mobilidade no mercado de trabalho paulista. Campinas: Autores Associados, 2000.

LAFER, Celso. Prefácio. In: PIOVESAN, Flávia. Direitos humanos e justiça internacional. São Paulo: Saraiva, 2006.

LEVITT, Peggy. Social remittances revisited, p. 23. Disponível em: <http://essays.ssrc.org|remittances_anthologylwp-contentluploads>. Acesso em: 2 ago. 2013.

LEWANDOWSKI, Enrique Ricardo. A formação da doutrina dos direitos fundamentais. Revista da Faculdade de Direito USP, São Paulo, v. 98, p. 172-173, 2003.

—. Globalização, regionalização e soberania. São Paulo: Juarez de Oliveira, 2004.

LIMA, Álvaro. Brasileiros na América. São Paulo: Sindicato dos Editores de Livros, 2009.

LIMA, Firmino Alves. Teoria da discriminação nas relações de trabalho. Rio de Janeiro: Elsevier, 2011. 
LOPES, Cristiane Maria Sbalqueiro. Direito de imigração: o Estatuto do Estrangeiro em uma perspectiva de direitos humanos. Porto Alegre: Núria Fabris, 2009.

LUCCI, Paula; MARTINS, Pedro. Migration and the United Nations Post-2015 Development Agenda. Switzerland: International Organization for Migration, 2013.

MALLET, Estevão. Conflito de leis trabalhistas no espaço e globalização. Revista LTr, São Paulo, v. 62, n. 3, p. 330-333, 1998.

MANNRICH, Nelson. A dispensa coletiva na comunidade europeia. Revista de Direito do Trabalho, São Paulo, v. 1, p. 1, 2000.

- Cenário: questão trabalhista desafia internacionalização. O Estado de S. Paulo, São Paulo, p. 2, 10 nov. 2006.

MARANHÃO, Délio. Instituições de direito do trabalho. 15. ed. atual. por Arnaldo Süssekind e João de Lima Teixeira Filho. São Paulo: LTr, 1995.

MARCONDES, Roberto Rangel. A importância da participação popular na definição do interesse público a ser tutelado pelo Ministério Público do Trabalho. 2010. Tese (Doutorado) - Faculdade de Direito da USP, São Paulo.

MARINUCCI, Roberto. Brasileiros e brasileiras no exterior: apresentação de dados recentes do Ministério das Relações Exteriores. Brasília: Ministério das Relações Exteriores, 2007. Disponível em: <http://www.csem.org.br/2008\roberto_ marinucci_brasileiros_e_brasileiras_no_exteriorsegundo_dados_do_mre_junho2008 .pdf>. Acesso em: 20 jun. 2013.

MARTIN, Philip. Labor migration and development indicators in the post-2015 global development framework. Migration and the united nations post-2015 development agenda. Editado por Frank Laczko e Lars Johan Lonnback, p. 86-87. Disponível em: 〈http://migration.ucdavis.edulmn〉>. Acesso em: 13 set. 2013.

MARTINS, Sergio Pinto. A OIT e a globalização. Revista IOB Trabalhista $e$ Previdenciária, v. 238, p. 197-206, 2009. 
MARTIN, Susan. US Employment-based admissions: permanent and temporary, migration policy: admission of high skilled workers. Georgetown Immigration Law Journal, n. 16, p. 619-636, 2002.

MATTOS, André Luis Borges de; DIAS, Guilherme Mansur (Org.). Trabalhadores migrantes e trabalho decente no Brasil. Brasília: MTE, 2009.

MAVERS, Günter. Global Mobility Handbook 2010. Vários colaboradores. Organização de Cassio Mesquita Barros. São Paulo: Saraiva, 2010. p. 90-103.

MAYER, Karl Ulrich. Intra-European migration during the past twenty years. International Migration Review, Unided Kingdom, p. 9, 1975.

MENEZES, Wagner. Ordem global e transnormatividade. Ijuí: Ed. Unijuí, 2005.

MINISTÉRIO DA PREVIDÊNCIA SOCIAL. Atuação governamental e políticas internacionais de Previdência Social. Brasília, 2009. (Coleção Previdência Social, v. 32.)

—. Migrações internacionais e Previdência Social. Brasília, 2006. (Coleção Previdência Social, v. 25.)

MINISTÉRIO DO TRABALHO E EMPREGO. Autorização de trabalho a profissionais estrangeiros no Brasil, legislação-base, coordenação geral de imigração, 2010.

MITRAUD, Milena Lôbo. A problemática da importação de mão de obra estrangeira. Pinheiro Neto Advogados, São Paulo, n. 1.689, p. 1-5, 2001.

MOROSINI, Marilia Costa (Org.). Mercosul: políticas e ações universitárias. Campinas: Autores Associados, 1998.

NASCIMENTO, Amauri Mascaro. Princípios do direito do trabalho e direitos fundamentais do trabalhador. Revista LTr, Legislação do Trabalho, v. 67, p. 903 916, 2003.

—. Teoria geral do direito do trabalho. São Paulo: LTr, 1998.

NINOMIYA, Masato. Brasil e Japão precisam avançar na cooperação jurídica. Tóquio. Japão. Disponível em: http://agencia.fapesp.br/16988. Acesso em: 29 set. 2013. 
NOVAIS, Denise Pasello Valente. Tráfico de pessoas para fins de exploração do trabalho: um estudo sobre o tráfico de bolivianos para exploração do trabalho em condição análoga à de escravo na cidade de São Paulo. 2008. Tese (Doutorado) Universidade de São Paulo, São Paulo.

OLIVEIRA, Andrei Fernandes de. Transferência internacional de empregados. São Paulo: LTr, 2008.

OLIVEIRA, Paulo Eduardo Vieira de. O dano pessoal no direito do trabalho. Revista da Amatra II, São Paulo, v. 3, n. 6, p. 5-21, 2002.

- Passado, presente e futuro do direito processual do trabalho no Brasil. In: SOUTO MAIOR, Jorge Luiz; CORREIA, Marcus Orione Gonçalves. (Org.). Curso de direito do trabalho: direito processual do trabalho. São Paulo: LTr, 2009. v. 4, p. $13-26$.

— - OLIVEIRA, O. Globalização e direito do trabalho. Revista Anamatra, São Paulo, v. 29, p. 39-42, 1996.

ORGANIZACIÓN INTERNACIONAL DEL TRABAJO. International labor migration: a rights-based approach. Ginebra, 2010.

OCTAVIO, Rodrigo. Direito do estrangeiro no Brasil. São Paulo: Francisco Alves, 1909.

PAIVA, Ana Lúcia Pinke Ribeiro de. Contrato internacional de trabalho: transferência de empregados. São Paulo: Saraiva, 2010.

PATARRA, Neide Lopes. Migrações internacionais de e para o Brasil contemporâneo. Volumes, fluxos, significados e políticas. Revista São Paulo em Perspectiva, v. 19, n. 3, p. 23-33, jul.-set. 2005.

PEIXOTO, João. A mobilidade internacional dos quadros. Oeiras: Celta Editora, 1999.

PERES, Antonio Galvão. Contrato internacional de trabalho: acesso à justiça. Conflitos de jurisdição e outras questões processuais. Rio de Janeiro: Elsevier, 2009. 
PIÑERO, Miguel Rodriguez; FERRER, Bravo. Legislación laboral, Ley Orgánica 4/2000 de 11 enero: trabajadores extranjeros. España: Rodesa, 2009.

PIOVESAN, Flávia. Direitos humanos e o direito constitucional internacional. 4. ed. São Paulo: Max Limonad, 2000.

-; CARVALHO, Luciana Paula Vaz de (Coord.). Direitos humanos e direito do trabalho. São Paulo: Atlas, 2010.

PÓVOA NETO, Helion; SPRANDEL, Marcia A. Brasil. Os objetivos da Conferência Internacional sobre População e Desenvolvimento (Cairo, 1994) e a política migratória brasileira, p. 317. Disponível em: <http://www.academia.edu/ 7843476/Os_objetivos_da_Conferencia_Internacional_Cairo 1994_e_a_política_migratoria_brasileira_com_2009>. Acesso em: 2 out. 2013

PRITCHETT, Lant. Let their people come: breaking the gridlock on international mobility. Washington: Brooking Institution Press, 2006.

RODRIGUES, Américo Plá. Princípios de direito do trabalho. Tradução de Wagner D. Giglio. São Paulo: LTr, 1978.

RODRIGUES, Fernando Henrique Lemos. Lições que a Cepal deixou ao Brasil. Jornal da Unicamp, Campinas, Universidade Estadual de Campinas, n. 347, 11 a 17 de dezembro de $2006 . \quad$ Disponível <http://www.unicamp.brlunicamp_hojeljornalIPDFljul347pg09pdf>. Acesso em: 24 jul. 2012.

POLASKI, Sandra. Jobs, wages, and household income. Nafta's Promisse and Reality: Lessons from Mexico for the hemisphere, 11.12. Carnegie Endowment for International Peace, 2003.

PORTES, Alejandro. Introduction: the debate and significance of immigrant and transnationalism. Global Networks, v. 1, n. 3, p. 59-61, 2001.

PORTUGAL, Garrigues. Jusprático laboral e segurança social. Lisboa: Wolters Kluwer, 2007. 
POSEMATO, Naiara. Cidadania e nacionalidade: efeitos e perspectivas nacionais regionais - globais. Organização de Arno Dal Ri Júnior e Odete Maria de Oliveira. 2. ed. Ijuí: Editora Unijuí, 2003.

PRITCHEET, Lant. Let their people come: breaking the gridlock on international labor mobility. Washington: Bookings Institution Press, 2006.

QUEIROZ, Jonas Marçal de. Artífices do próspero mundo novo: colonos, migrantes e migrantes em São Paulo e no Pará (1868-1889). 2006. Tese (Doutorado) Faculdade de Filosofia, Letras e Ciências Humanas (FFLCH), São Paulo.

PERES, Antonio Galvão. Contrato internacional de trabalho: novas perspectivas. São Paulo: LTr, 2004.

RAMOS, André de Carvalho. Direitos dos estrangeiros no Brasil, a imigração, direito de ingresso e os direitos dos estrangeiros. In: SARMENTO, Daniel; IKAWA, Daniela; PIOVESAN, Flávia (Org.). Igualdade, diferença e direitos humanos. Rio de Janeiro: Lumen Juris, 2008. p. 721-745.

; RODRIGUES, Gilberto; ALMEIDA, Guilherme Assis de (Org.). Perspectivas de futuro. São Paulo: CL-A Cultural, 2011.

RATHA, D. Worker's remmittances: an importante and stable source of external development finance, 2003. Relatório do Banco Mundial Global Development Finance, p. 152-150.

ROMITA, Arion Sayão. Conflito de normas em direito do trabalho. In: MALLET, Estevão; ROBORTELLA, Luiz Carlos Amorim (Coord.). Direito e processo do trabalho: estudos em homenagem ao Prof. Octávio Bueno Magano. São Paulo: LTr, 1996. p. 74.

—. Prestação de serviços no exterior. Conflito de leis no espaço. Revista IOB de Direito Trabalhista e Previdenciário, São Paulo, IOB Thomson, ano 19, n. 228, p. 8. 
REIS, Rossana Rocha. A política do Brasil para as migrações internacionais. Contexto, Rio de Janeiro, v. 33, jun. 2011. Disponível em: <http://dx.doi.org;10.1590\SO102$85292011000100003 \&$ Ing=en\&nrm=iso>. Acesso em: 5 out. 2013.

—. Migrações: casos norte-americano e francês. Esd. Av. São Paulo, v. 20, n 57, ago. 2006. Disponível em: <http://www.scielo.php?script=sci_arttex\&pid=SO10340132-06000200006\&Ing=en \&nrm=iso>. Acesso em: 8 out. 2013.

REIS, Palhares Moreira. Estrangeiro no serviço público. Adcoas Trabalhista, São Paulo, v. 2, n. 20, p. 7-27, 2001.

RELATÓRIO TERRITORIAL DA OCDE: Brasil 2013, OECD Publishing. Disponível em: <http://www.oecd-ilibrary.orflurban-rural-and-regional-depvelopn>. Acesso em: 21 out. 2013.

REZERA, Danielle do Nascimento. Gênero e trabalho: mulheres bolivianas na cidade de São Paulo 1980 a 2010. 2012. Dissertação (Mestrado) - Universidade de São Paulo, São Paulo.

ROCHA, Ilana Peliciari. Imigração internacional em São Paulo: retorno e reemigração, 1890-1920. 2007. Tese (Doutorado) - Faculdade de Filosofia, Letras e Ciências Humanas da USP, São Paulo.

ROCHA, Maria Elizabeth Guimarães Teixeira. A incorporação das normativas mercosulinas - UniCEUB. Disponível em: <http://www. publicacoesacademicas.uniceub.brlindex.phplarticle...\1331>, p. 4-10. Acesso em: 22 set. 2013.

ROMERO, Álvaro Alconada. Cartografias da imigração: interculturalidade e políticas públicas. Lisboa: Etnográfica, 2009.

RUHS, Martin. The price of rights: regulating international labor migration. Princeton: Princeton University Press, 2013.

SANTOS, Enoque Ribeiro dos. Internacionalização dos direitos humanos trabalhistas: o advento da dimensão objetiva e subjetiva dos direitos fundamentais. Revista do Ministério Público do Trabalho, v. 36, p. 109-127, 2008. 
-; FARINA, Bernardo Cunha. Revista do Ministério Público do Trabalho/Procuradoria-Geral do Trabalho, Brasília, ano 1, n. 1, mar. 1991.

SANTOS, Milton. Por uma outra globalização: do pensamento único à consciência universal. 4. ed. Rio de Janeiro: Record, 2000.

SARLET, Ingo Wolfgang. A eficácia dos direitos fundamentais. 2. ed. rev. atual. Porto Alegre: Livraria do Advogado, 2001.

SASAKI, Eliane. A imigração para o Japão. Estud. av. [on line]2006, v. 20, n. 57. Disponível em: <http://scielo.br/scielo.php?script=arttex\&pid=S0103$401420060002000009 \&$ ing >. Acesso em: 5 set. 2013.

SAYAD, Abdelmalek. A imigração: ou os paradoxos da alteridade. São Paulo: Ed. Universidade de São Paulo, 2008.

SEMINÁRIO MÃO DE OBRA ESTRANGEIRA NO BRASIL E BRASILEIRA NO EXTERIOR. 10. ed. 2 set. 2010, Brasília. Perguntas dirigidas ao Dr. Paulo Sérgio de Almeida, Coordenador-Geral de Imigração, Ministério de Trabalho e Emprego.

SILVA, H. B. M. Como não se deve flexibilizar a legislação trabalhista: um estudo sobre o caso da proposta de alteração do artigo 618 da Consolidação das Leis do Trabalho 2002. Artigo publicado na internet.

SILVA, Otavio Pinto e. A nova face do direito do trabalho: tecnologia, desemprego, trabalho autônomo e trabalho informal. Revista do Advogado, São Paulo, v. 25, n. 82, p. 95-103, 2005.

—. Subordinação, autonomia e parassubordinação nas relações de trabalho. São Paulo: LTr, 2004. v. 1.

SILVA, Walküre Lopes Ribeiro da. Aplicabilidade da Declaração Sociolaboral do Mercosul no Brasil. In: OIT (Org.). Eficacia jurídica de la Declaración Sociolaboral del Mercosur: trabajos de la Reunión Técnica celebrada en Buenos Aires, los días 10 y 11 de diciembre de 2001. Buenos Aires: OIT, 2002. p. 47-80. . Aspectos jurídicos das relações de trabalho dos brasileiros no Japão. Revista do Tribunal Regional do Trabalho da 15. ${ }^{a}$ Região, Campinas, n. 23, p. 260-271, 2003. 
SILVEIRA JUNIOR, Mesac Roberto. A travessia que mancha o corpo: imagens da imigração e a educação transitória. 2008. Tese (Doutorado) - Faculdade de Educação USP, São Paulo.

SMITH, Adam. A riqueza das nações. São Paulo: Nova Cultural, 1996.

SOARES, Guido Fernando Silva. Os direitos humanos e a proteção dos estrangeiros. Guido Fernando Silva Soares. Revista de Informação Legislativa, Brasília, ano 41, n. 162, p. 169-204, abr.-jun. 2004.

SOLÉ, Ana Garicano. Global Mobility Handbook 2010. Vários colaboradores. Organização de Cassio Mesquita Barros. São Paulo: Saraiva, 2010. p. 208-213.

SOUTO MAIOR, Jorge Luiz. Globalização humanista: a cachambra real no jogo das relações de trabalho. Jornal Trabalhista Consulex, Brasília, v. 19, n. 941, p. 12-13, 2002.

SPADA, Carolina Benedet Barreiros. Contribuição previdenciária devida sobre as verbas trabalhistas pagas aos empregados transferidos para o exterior: Lei 11.962/2009. 2013. Monografia - Escola Paulista de Direito, São Paulo.

SÜSSEKIND, Arnaldo. Conflitos de leis do trabalho. Rio de Janeiro: Freitas Bastos, 1979. . Convenções da OIT. 2. ed. São Paulo: LTr, 1998.

TRUETT, Lila J.; TRUETT, Dale B. Revista Contemporary Economic Policy, United States, Ed. Western Association International Audience, v. 25, p. 2-5, July 2007.

URIARTE, Oscar Ermida. Prefácio In: LIMA, Firmino Alves. Teoria da discriminação nas relações de trabalho. Rio de Janeiro: Elsevier, 2011.

USHIJIMA, Fernanda Rais. A política externa brasileira para os emigrantes e seus descendentes. São Paulo: Cultura Acadêmica, 2012.

VALENTE, Denise Pasello. Tráfico de pessoas para exploração do trabalho. São Paulo: LTr, 2012.

VELASCO, Paulo Afonso. O Mercosul entre a geografia e a história: desafios, iniciativas e perspectivas. Revista Candelária, v. 6, p. 15, jan.-jun. 2007. 
VENTURA, Deisy. As assimetrias entre o Mercosul e a União Europeia. São Paulo: Manole, 2003.

VILELA, Elaine Meire. Desigualdade e discriminação de migrantes internacionais no mercado de trabalho brasileiro. Rio de Janeiro, v. 54, n. 1, 2011. Disponível em http://www.scielo.br/scielo.php?script=sci_arttext\&pid=S0011-525820110001 00003\&lng=en\&nrm=iso>. Acesso em: $11 \mathrm{dez} .2011$.

- Imigração internacional e estratificação no mercado de trabalho brasileiro. 2008. Tese (Doutorado) - Faculdade de Filosofia e Ciências da Universidade de Minas Gerais. Disponível em: <http://www.bibliotecadigital.ufmg.br/dspace/bitstream/handle/1843/VCSA874kj4.pdf>. Acesso em: 30 set. 2013.

VILHENA, Paulo Emílio Ribeiro de. Trabalhador brasileiro no estrangeiro, Revista de Informação Legislativa, Brasília, v. 21, n. 82, p. 195-230, 1984.

VOIRIN, M. A social security for migrant workers in Africa. International Labor Review, n. 122, v. 3, p. 329-342, May-June 1983. 